
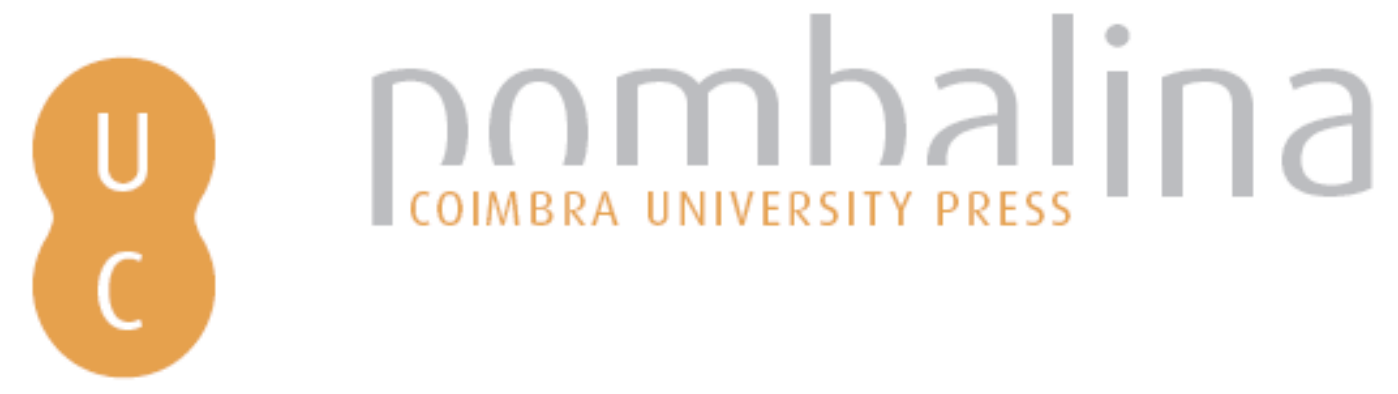

\title{
Um paradigma no céu: Platão político, de Aristóteles ao séc $\mathbf{X X}$
}

Autor(es): $\quad$ Vegetti, Mario; Pina, Maria da Graça Gomes de, trad.

Publicado por: Imprensa da Universidade de Coimbra

URL

persistente: $\quad$ URI:http://hdl.handle.net/10316.2/34791

DOI: $\quad$ DOI:http://dx.doi.org/10.14195/978-989-26-0946-1

Accessed : $\quad$ 26-Apr-2023 14:50:46

A navegação consulta e descarregamento dos títulos inseridos nas Bibliotecas Digitais UC Digitalis, UC Pombalina e UC Impactum, pressupõem a aceitação plena e sem reservas dos Termos e Condições de Uso destas Bibliotecas Digitais, disponíveis em https://digitalis.uc.pt/pt-pt/termos.

Conforme exposto nos referidos Termos e Condições de Uso, o descarregamento de títulos de acesso restrito requer uma licença válida de autorização devendo o utilizador aceder ao(s) documento(s) a partir de um endereço de IP da instituição detentora da supramencionada licença.

Ao utilizador é apenas permitido o descarregamento para uso pessoal, pelo que o emprego do(s) título(s) descarregado(s) para outro fim, designadamente comercial, carece de autorização do respetivo autor ou editor da obra.

Na medida em que todas as obras da UC Digitalis se encontram protegidas pelo Código do Direito de Autor e Direitos Conexos e demais legislação aplicável, toda a cópia, parcial ou total, deste documento, nos casos em que é legalmente admitida, deverá conter ou fazer-se acompanhar por este aviso.

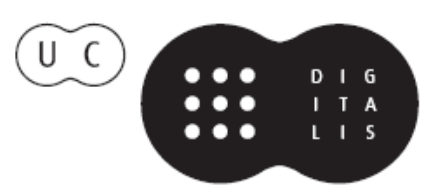




\section{Um paradigma no céu}

Platão político, de Aristóteles

$$
\text { ao século } \mathrm{xx}
$$

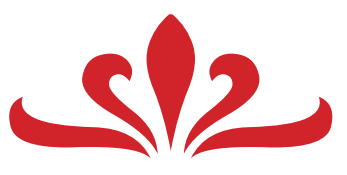

Mario VegetTi
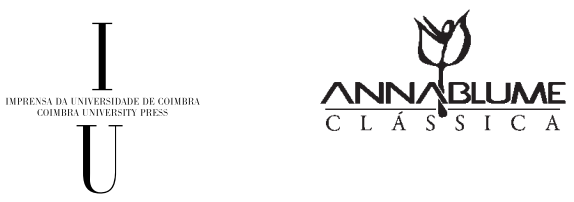
(Página deixada propositadamente em branco) 


\section{Um paradigma no céu Platão político, de Aristóteles ao século xx}


(Página deixada propositadamente em branco) 


\title{
Um paradigma no céu Platão político, de Aristóteles ao século $\mathrm{xx}$
}

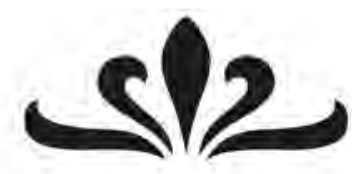

\section{Mario Vegetti}

\author{
Tradução de
}

Maria da Graça Gomes de Pina

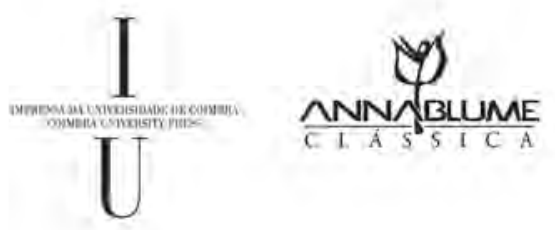




\section{COEDIÇÃO}

Imprensa da Universidade de Coimbra URL: http://www.uc.pt/imprensa_uc

ANNABLUME editora . comunicação www.annablume.com.br

\section{PROJETO E PRODUÇÃO}

Coletivo Gráfico Annablume

\section{IMPRESSÃO E ACABAMENTO \\ LinkPrint}

\section{ISBN}

978-989-26-0260-8 (IUC)

978-85-391-0153-4 (Annablume)

ISBN Digital

978-989-26-0946-1

DOI

http://dx.doi.org/10.14195/978-989-26-0946-1

\section{DEPÓSITO LEGAL}

$350536 / 12$

(C) JUNHO 2012

ANNABLUME

IMPRENSA DA UNIVERSIDADE DE COIMBRA 


\section{SUMÁRIO}

APRESENTAÇÃo

$\begin{array}{ll}\text { PREMISSA } & 21\end{array}$

1. Platão político 25

OS TEXTOS 25

A BIOGRAFIA 27

O Que significa “política” em Platão? 32

Nota BIBLIOGRÁFICA 41

2. Nas origens da INTERPRETAÇÃO 43

ARISTÓTELES: O CÂNONE DA CRÍTICA POLÍTICA 43 PROClO: A HERMENÊUTICA DA DESPOLITIZAÇÃO 56 Idade Média e Renascimento: DA ALEGORIA À TEOLOGIA $\quad 61$

NotA BIBLIOGRÁfICA 66

3. Os PARAdigmas DA MODERNIDADE 67 
KANT: OS IDEAIS DA RAZĀO 67

HEGEL: O "ESPÍRITO DO TEMPO" 73

Entre Kant e Hegel: liberalismo e SOCIALISMO 82

OS GRANDES HISTORIADORES: ZELLER, GROTE, GOMPERZ 82

Platão "socialista": PÖHLManN e Natorp 96 Nota BIBLIOGRÁFICA 108

4. Do Terceiro humanismo ao Platāo “nazı” 111 “Sob a bandeira de Platão”: Wilamowitz, JAEGER, STENZEL 111 A Usurpação Nazi de Platão 124 NotA BIBLIOGRÁFICA 139

5. Platão no Ocidente entre as duas Guerras: FranÇA, ItÁlia, INGLATERRA 143

Platão Político em França 143

Católicos E liberais Na Itália Fascista 148 EM TERRA LIBERAL-DEMOCRATA 160 E OS BOLCHEVIQUES? $\quad 170$ NotA BIBLIOGRÁFICA 172

6. Historicismo E ENGENHARIA SOCIAL: o Platão de Popper 175

Por Quê Platão? 175

Diagnósticos E TERAPIAS 177

PlatÃo E O HISTORICISMO REgRESSIVO 179

A ENGENHARIA SOCIAL UTÓPICA 184

DePOIS DE POPPER 187

Nota BIBLIOGRÁFICA 191 
7. Defender Platão de Popper

(OU DE SI MESMO?)

Platão liberal-DEMOCRATA 195

Platão UTÓPICO 205

PLATÃo IRÔNICO 207

IRONIA 216

EROS 220

FILOSOFIA E POLÍTICA 222

NotA BIBLIOGRÁFICA 227

8. Platão sem Política 231

PlatÃo IMPolítico 231

KATOIKIZEIN 240

A QUESTÃO DA CARTA VII 244

UMA RÉPliCA ALÉM DO MURO:

O STREIT UM PLATON NA DDR 249

Nota BIBLIOGRÁFICA 253

9. A QUESTÃo DA UTOPIA 257

UTOPIAS DE EVASÃO 257

UTOPIA DE RECONSTRUÇÃO 259

DA UTOPIA PROJETUAL À TEORIA NORMATIVA 262

NotA BIBLIOGRÁFICA 268

10. Platão político, hoje 271

A POLISSEMIA PLATÔNICA 271

O EXCESSO HERMENÊUTICO 274

O QUE SOBRA? 276

NotA BIBLIOGRÁFICA 283

ÍNDICE DOS NOMES 285 
(Página deixada propositadamente em branco) 


\section{APRESENTAÇÃO}

1. Em República IX 592b1, após um longo desenvolvimento dialógico que visava construir a "bela cidade" com a finalidade de definir a ideia de justiça, Sócrates diz que tal cidade jamais existiu, mas que consiste em um "paradigma no céu" a ser contemplado. A passagem consiste em um dos pontos mais discutidos do diálogo platônico, e Mario Vegetti emprega como motivo para sua obra acerca da história das interpretaçóes do pensamento político de Platão, notadamente da República, que compreende vinte e quatro séculos.

A obra nasce como um dos resultados que se acrescentaram à empresa do monumental comentário da República dirigido por Vegetti, publicada em 7 volumes pela editora napolitana Bibliopolis entre os anos de 1996 e 2007. Vegetti havia dedicado-se a outros aspectos do pensamento platônico ao longo de diversos estudos, podendo ainda ser destacados os volumes L'etica degli antichi (Bari, Laterza, 1989), Quindici lezioni 
su Platone (Torino, Einaudi, 2003), bem como o guia esquemático à leitura da República (Guida alla lettura della Repubblica di Platone. Bari, Laterza, 1999).

Basta uma primeira leitura da República para que o leitor veja-se envolto no universo de uma pluralidade de teses, opiniōes e questões que não permitem uma síntese sem ocultar algum aspecto da obra. As dynameis inscritas em cada página da obra platônica serão mostradas pela multiplicidade de interpretações de seu aspecto político. Sabemos que somente por abstração podemos separar a reflexão platônica acerca da política daquela acerca do conhecimento, da moral, da psicologia, da cosmologia, de modo que não há uma obra que o filósofo dedica exclusivamente ao que hoje denominamos política, sendo que o sentido de "as coisas políticas" (tà politikà) possui um sentido diverso daquele que hoje conferimos à política, ao dizermos "filosofia política".

Após traçar alguns comentários acerca da vocação política de Platão, tal como descrita na Carta VII, e de apresentar as grandes linhas da República, Vegetti adverte o leitor de que é precisamente o eixo da política, sempre vinculada ao discurso sobre o ser e o conhecer, que motivará sua plurissecular tradição interpretativa. Tal unidade entre os diversos aspectos do pensamento platônico será tratada por Vegetti nos termos do triângulo ser, verdade, valor, cuja primeira grande disjunção será operada por Aristóteles no livro II da Política. Na crítica aristotélica podem ser notados os elementos que constituirão os pontos mais polêmicos para toda a tradição, particularmente os conteúdos dos livros IV 
e V do diálogo, sobretudo no caso daquilo que Sócrates chama das três "vagas" ou "ondas" que deverão ser enfrentadas naquele momento da construção da cidade. São eles: a capacidade das mulheres para o governo, a comunidade de filhos e bens e a necessidade dos filósofos serem reis ou dos reis serem filósofos. É sobretudo ao problema da dissolução da família e da propriedade que Aristóteles dirige sua atenção. A unidade e a comunhão absolutas negam a essência pluralista da cidade, que se funda na colaboração entre os indivíduos. Tal nível de unidade idealizada por Platão não é realizável nem desejável. Aristóteles acrescenta ainda que a dissolução da posse privada é algo que priva os homens de prazer, aniquila a amizade e generosidade entre eles. Nesse tipo de cidade una a infelicidade é universal. A esses argumentos aristotélicos, Vegetti acrescenta o comentário de um argumento que chama de "historicista", mobilizado por Aristóteles contra Platão. No decorrer do tempo, alguns gêneros de cidade foram descartados dada a sua impossibilidade e inadequação à vida humana. Tanto na ordem da natureza quanto na dos valores, a cidade platônica não é realizável nem desejável.

A tensão entre desejável e realizável será objeto de uma longa oscilação no campo das interpretaçōes posteriores. Vegetti volta-se, portanto, para a tradição platônica tardia, analisando o caso de Proclo, autor do grande e sistemático comentário à República no período. Mostra como Proclo é um dos primeiros a ressaltar as muitas reticências existentes no texto do diálogo platônico, interpretação que será retomada por várias 
escolas da crítica moderna. Na leitura procliana, em resposta a Aristóteles, a unidade da cidade deve ser compreendida no sentido de uma finalidade em direção ao todo e não como aniquilação do elemento plural do polis. Quanto ao comunismo absoluto, Proclo argumenta que a educação fará com que os indivíduos possam privilegiar o bem comum, de modo que os bens poderão ser distribuídos de acordo com a necessidade de cada um. Por outro lado, o autor observa que a interpretação procliana leva à sistemática diluição do conteúdo político do diálogo, assumindo uma interpretação alegórica que se remete a conteúdos teológicos, psicológicos ou cosmológicos. Esse tipo de interpretação, como será visto, dura ao longo dos períodos medieval e renascentista, e, de outra perspectiva e por outros motivos, ressurge no mundo contemporâneo.

Vegetti chama a atenção para a posição secundária da República na ordem de leitura dos diálogos platônicos no final da Antiguidade. Vale notar que uma perspectiva de combinação entre os diálogos já se inscrevia na estratégia plotiniana de articulação dos livros centrais da República a diálogos como o Parmênides, o Banquete, o Fedro e o Fédon, embora Plotino notasse as diferenças e contradiçóes existentes entre os diálogos, o que lhe apresentava a necessidade de interpretação de seu caráter enigmático. No comentário sistemático de Proclo, a perspectiva com relação àquela plotiniana será diversa (temática que Vegetti tratou, em parceria com M. Abbate, na organização do volume $L a$ Reppublica di Platone nella tradizione antica. Napoli, Bibliopolis, 1999). 
2. Na época moderna a discussão sobre o sentido da República reaparece no interior da investigação kantiana acerca da noção de "ideia" e de sua resposta à crítica ao caráter quimérico do diálogo platônico feita por Brucker (cf. cap. 3). Nesse sentido, Kant visava esclarecer o sentido da noção de "ideia" recorrendo ao campo éticopolítico, acabando por responder, de modo indireto, às críticas aristotélicas feitas na Política. Para Kant, o pressuposto, assumido por muitos, da impossibilidade de realização é um argumento inadequado para a rejeição da República, pois o campo do que é ideal não pode ser julgado conforme regras empíricas. Em outras palavras, é necessário distinguir ser e dever ser, fato e valor, o que não é feito pelas críticas "naturalistas" e "historicistas", que reduzem o elemento normativo-transcendental de modelos, que são reguladores e não leis positivas. Assim, o caráter regulador da ideia é exercido como critério de juízos de valor, bem como finalidade da práxis, havendo uma mútua implicação entre ambos os níveis (critério e telos). Os fatos não são perfeitamente adequados às ideias, e não podem exercer a função arquetípica e reguladora específica da ideia. Nesse sentido, seria inadequado exigir de um modelo normativo a historicidade e a factibilidade que os críticos de Platão mencionados exigem.

Valendo-se de uma estratégia que percorre toda a obra, isto é, mostrar os limites das diversas interpretações, Vegetti aponta para as dificuldades oferecidas pela perspectiva kantiana, sobretudo com relação à interpretação do preceituário factual contido no diálogo (tal como a abolição da propriedade e da família, contido 
nos livros centrais). Ou seja, permanece a problemática da relação entre dimensão formal e dimensão de conteúdo, implicada no caráter normativo do diálogo.

Note-se que o percurso das interpretações que ainda será feito pelo leitor revela a oscilação permanente entre o caráter quimérico, o factual e o normativo da República. É assim que, ao contrário de Kant, para Hegel a República possui caráter mais descritivo que normativo. Nas Liçôes sobre História da Filosofia, o filósofo retoma a acusação, cuja ressonância remonta a Aristóteles, segundo a qual Platão teria construído um ideal supérfluo. No entanto, Hegel nota que não se deve compreender o ideal como algo ocioso, que "deve ser" realizado, mas como o próprio "real". $\mathrm{O}$ sentido da exigência platônica do filósofo-rei diz respeito ao domínio do campo dos princípios universais na dimensão política, que traduzem a mútua implicação entre ideal e real. Em outras palavras, na perspectiva hegeliana, o projeto filosófico contido na República seria aquele de traduzir no campo do conceito a racionalidade do âmbito político. A Filosofia reflete acerca de processos já realizados e os transforma em campo de elaboração conceitual, não elabora projetos eficazes no campo político. É assim que, para Hegel, é inadequado tanto considerar o caráter quimérico do conteúdo da República quanto a interpretação que a toma como ideia reguladora. Platão não teria proposto ideais vazios aos quais a realidade deveria se adaptar, mas transpôs para o campo do conceito a crise de seu próprio tempo, isto é, a vida ético-política grega e seus limites históricos. Aliás, nesse ponto, Vegetti faz uma 
observação acerca dos problemas apresentados pelas traduções hegelianas de termos gregos como polis, demos ou noûs, que terão longa vida nas posteriores traduções de Platão, e que geraram muitos critérios equívocos de interpretação.

3. Com historiadores da Filosofia como Zeller, Grote e Gomperz há uma nova forma de abordagem do pensamento político platônico, integrada aos critérios historiográficos e filológicos que se consolidarão ao século XX. Mas se as leituras serão marcadas por sua exigência de um rigor interpretativo que obedece àqueles critérios, Vegetti mostra como serão mantidas, ainda que de modo subjacente, as perspectivas filosóficas (de kantianas a hegelianas) que lhes são contemporâneas. É o que ocorre da interpretação da obra clássica de Zeller ao surgimento de leituras "socialistas" como a de Pöhlmann.

À geração dos grandes historiadores do final do século XIX e início do XX sucedeu-se aquela da filologia clássica alemã, com representantes como Willamowitz e Jaeger. No caso deste último, vê-se como ocorre uma transformação de sua interpretação ao longo dos anos de publicação da Paidéia, que oscila de uma exaltação da afinidade entre o projeto descrito por Platão e as expectativas relativas à superação da crise e à restauração da autêntica cultura, vinculada ao "espírito do povo alemão" até uma mudança radical de perspectiva nos anos em que o filólogo viu tais expectativas frustradas. E é precisamente nesse ponto que o rigor filológico revela os limites no campo das sínteses que serão feitas no período que circunscreve as duas grandes guerras. 
Na primeira metade do século XX, a polêmica acerca do Platão político adquire contornos particulares, correspondentes às convulsões sócio-políticas que o agitaram. A crise da cultura refletirá a variabilidade de paradigmas interpretativos da obra platônica, que se estende de uma leitura fascista ou socialista até a visão liberal-democrata.

Será, no entanto, a interpretação de K. Popper, que escreve diante do impacto causado pela ascensão dos totalitarismos na Europa, que produz uma grande variedade de respostas e críticas, cujos ecos podem ser encontrados até nossos dias. A sociedade aberta $e$ seus inimigos posiciona Platão como o grande autor do pensamento totalitário que vigorou posteriormente no Ocidente. Vegetti analisa com grande perspicácia as críticas de Popper, mostrando como, ao tentarem dar-lhe uma resposta, os defensores de Platão acabam ou por assumir de modo tácito as teses daquele (o que já ocorria com as respostas a algumas apropriações ideológicas mencionadas), ou verem-se diante da tentativa de defender Platão de si mesmo. Contudo, são tais tentativas que geram estratégias interpretativas que renovam a forma de ler a República e que hoje são consensuais entre os críticos.

Além do Platão utópico, mencionemos o caso de L. Strauss, cuja concepção é de que o método empregado por Platão é a ironia, expressa na forma dialógica. Novamente, as três vagas são exemplos da hipérbole empregada no diálogo, que denota a impossibilidade de realização do comunismo absoluto ou a incompatibilidade da figura do filósofo com a atividade política. A 
kallipolis não seria, portanto, nem realizável nem desejável. O que ocorre é a construção de uma utopia que se refuta a si mesma, e aponta para os limites da política. Tais limites estruturais não permitem tomarmos a $R e-$ pública como obra de um pensador liberal-democrata, fascista ou comunista, refutando não apenas a Popper, mas a outras formas de apropriação do que seria o conteúdo político do diálogo. Sendo a ironia, não pode ser tomado como doutrina política de Platão.

4. Nos capítulos finais, Vegetti dedica-se ao sucesso das estratégias contemporâneas de refutação definitiva das teses popperianas, que dissolvem o elemento político do pensamento platônico na chave irônicoutópica. Mençôes de destaque cabem, a esse respeito, às leituras de E. Vögelin e J. Annas, para quem as "vagas" que aparecem no livro $\mathrm{V}$ denotam a intenção deliberadamente não realista de tais propostas. $\mathrm{O}$ que está em jogo são questões psicológicas.

Desse ponto da história da interpretação, nos últimos 20 anos as teses acerca da República não mais poderão descuidar dos elementos retórico-literários e das estratégias implícitas no método dialógico, mas muitas vezes reduzindo toda a análise a tais elementos. Vegetti nota, no entanto, que para outros, a concepção do diálogo como metáfora que guarda um potencial persuasivo com relação aos personagens interlocutores de Sócrates não a expropria de suas teses filosóficas acerca da política, no entanto, reafirmando a superioridade da filosofia sobre a política, seguindo Strauss.

Ao concluir suas análises, Vegetti retorna à frase do livro IX que fornece o título de sua obra. Nota 
que ela é uma das passagens mais fortes para a negação ou enfraquecimento do conteúdo político do diálogo. Após retomar a tradução de J. Adam de heautòn katoikizein ("fundar uma cidade em si mesmo"), que conduz a uma leitura apenas psicológica do desenvolvimento argumentativo, observa que podemos compreender "céu" e "paradigma" como indicadores da teoria normativa para a ação do filósofo, embora note sua dificuldade. Mas que o leitor não se apresse, pois o autor ainda observa a necessidade de uma análise da relevância da Carta VII para a compreensão do Platão político, contudo concluindo pela afirmação de que a questão da Carta permanece em aberto, dada a polêmica sobre sua autenticidade, que envolve várias questôes historiográficas e filológicas.

Ao comentar a perspectiva de Gadamer, Vegetti mencionava a diferença feita posteriormente entre utopias de evasão da realidade (idade do ouro, ilhas dos bem-aventurados, etc) e utopias de reconstrução, que será retomada no final da obra. Com Finley, Vegetti pondera a prevenção platônica contra o primeiro tipo, citando um passo de Rep. V 458 a-b. No entanto, é necessário considerar o caso da utopia de reconstrução analisando as metáforas pictóricas (o filósoforei como pintor de constituições) nos livros V e VII. O ideal kantiano retornaria no campo de uma interpretação da utopia como ficção que oferece um modelo imaginário provido de eficácia discursiva e normativa a fim de oferecer elementos críticos com relação à realidade. Aqui são mencionadas as interpretações de Burnyeat e Morrison, além da "teoria normativa" da sociedade justa de J. Rawls. 
O contraponto retroativo poderá ser feito pelo leitor na medida em que recorde as interpretaçóes feitas na primeira metade do século XX. A tais leituras da República, Vegetti chama, ao final, de "não comedidas", absurdas e enganadoras, uma vez que estamos diante de um texto teórico e não propagandista. Este é um dos traços que percorrem o eixo do livro de Vegetti e que mostra as formas de apropriação política de um clássico ao longo do turbulento século que nos precede, notadamente de seus períodos mais críticos, entre duas grandes guerras e na emergência dos grandes totalitarismos.

5. Vegetti conclui ressaltando a polissemia platônica, mostrando que ao longo dos séculos de leitura, os intérpretes de Platão puderam encontrar elementos textuais que propiciam o pendor para esta ou aquela alternativa, tal como ocorre com os grandes textos que percorreram a história do Ocidente. Exemplo disso é a divisão já existente na Antiguidade entre um Platão cético e um dogmático. Mas o autor nos lembra que é inadequada qualquer redução da filosofia platônica à uma opção exegética que exclui radicalmente as outras, anulando a "polissemia irredutível" do pensamento do filósofo. A existência de um suposto platonismo unificado é fruto de um processo hermenêutico da última fase da Antiguidade tardia, bem como a vinculação dos diálogos políticos a essa tradição é algo do nosso tempo. Desse modo, Vegetti nota o "excesso hermenêutico" no campo da política, operado a partir de Hegel (por exemplo, nas leituras do Platão totalitário, para quem a comunidade suprime absolutamente o indivíduo, bem como nas respostas a esse tipo de 
paradigma). Tal extrapolação adquire cores que Vegetti chama de "patológicas", marcadas por um anacronismo radical, ou seja, são posições que se encontram nos séculos XIX ou XX, não em Platão. A sobriedade de sua análise pode notar, por isso, que cada intérprete pode chamar a atenção para um aspecto do texto que foi ignorado por outro, tal como o mostra ao longo de sua exposição.

A República já foi chamada de "odisséia da filosofia” (cf. J. Howland), Vegetti conduz o leitor pela odisseia das interpretações do diálogo, que se confunde com a própria história da filosofia ocidental, com a extraordinária precisão sintética, a clareza e a penetração, características das suas obras.

Aqui talvez não seja ocioso recordar a observação de I. Calvino a propósito da obra clássica, que é sempre objeto de uma releitura. Ao concluir o livro de Vegetti, novamente é a lição da polissemia estrutural do fazer filosófico platônico que aprendemos, com os estímulos críticos que tal pensamento nos oferece por sua distância no tempo, em suas interrogações acerca da cidade e da alma.

Mauricio Pagotto Marsola

São Paulo, Agosto de 2010. 


\section{PREMISSA}

A obra política de Platão constituiu, já na antiguidade, e depois, sobretudo nos séculos XIX e XX, um dos mais violentos campos de batalha em que se desencadeou o conflito das interpretaçóes. Certamente isto faz dela um caso de importância capital na história da receção e da eficácia dos textos filosóficos que - sendo já convicção geral - se mostra útil para a compreensão quer do autor, quer das culturas que o interpretam. Quando depois, como acontece no nosso caso, a amplitude do leque hermenêutico é tal que é capaz de aparecer até escandalosa, a sua reconstrução historiográfica torna-se indispensável para evitar a desorientação na leitura desses textos ou a adoção de pontos de vista preconceituosos, num sentido ou no outro; por outro lado, esta mesma leitura não se pode eximir de dar conta de uma plurissecular tradição exegética tão radicalmente conflituosa.

A pesquisa a que este livro se dedica nasce, por assim dizer, "em trabalho de campo", isto é, devido a questôes 
suscitadas por um trabalho de comentário à República de mais de uma década. A pluralidade de interpretaçóes encontradas na enorme literatura relativa a este diálogo não podia ser considerada uma simples questão de bibliografia especializada mas, pelo contrário, devia ser reconstruída e interpretada como vicissitude cultural em si mesma, porém, absolutamente não privada da influência do texto platónico na nossa pré-compreensão. Adquirir consciência crítica dela significava poder ler o Platão político certamente não de um ponto de vista "neutro" (presunção não só ingénua como impossível), mas atento ao que se encontra em jogo no conflito das interpretações e da sua complexa estratificação.

Alguns resultados da investigação, no que diz respeito a Platão, por um lado, e à história das suas interpretações, por outro, são indicados nos últimos dois capítulos do livro, mas a discussão das vicissitudes hermenêuticas está naturalmente presente em cada parte dele.

A reconstrução da história exegética do Platão político aqui delineada apresenta lacunas que devem ser justificadas. A primeira, de carácter cronológico, diz respeito ao período de tempo que vai do século XVI ao século XVIII (rico em discussões sobre Platão). Isto deve-se ao facto que a questão de que parti concerne sobretudo às interpretações da modernidade. Era-me necessário reconstruir os pressupostos antigos e humanísticos que agiram de modo mais ou menos implícito também nos intérpretes modernos, porém, repercorrer toda a vicissitude histórica teria afastado excessivamente a investigação da sua destinação principal, a saber, as leituras platónicas dos séculos XIX e XX, que ainda orientam 
de forma direta a produção historiográfica acerca do pensamento político do filósofo.

Por outro lado, decidi concentrar a atenção em autores e obras que me pareciam centrais e decisivos, omitindo muitos outros, até significativos. Pareceu-me mais interessante analisar de perto as razôes e as argumentaçôes expostas nos textos cruciais da vicissitude histórica, mais do que fazer um resumo abrangente, por assim dizer, nos moldes 'de um sobrevoo', como faz, por exemplo, o brilhante livro de Melissa Lane sobre Plato's Progeny. Só uma verificação rigorosa e bem documentada me parecia capaz de ir além da mera constatação de uma bizarra variedade de interpretaçōes, para compreender de forma mais aprofundada a sua posição e motivos e, também, eventualmente, para apreender aquilo que havia por apreender com a finalidade de uma leitura mais consciente de Platão.

Por fim, convém notar que a investigação versa sobretudo sobre a República. Isto deve-se ao facto de que este diálogo - muito mais que o Politico e as Leis - constituiu a questão mais relevante no conflito das interpretaçōes, relegando os outros textos a uma posição geralmente marginal ou subalterna.

O título do livro, Um paradigma no céu, é uma citação da célebre passagem da República IX 592b, que será discutida no CAP. 8.

A primeira ocasião para trabalhar neste tema foi-me oferecida pelo falecido amigo Emanuele Narducci que me convidou a falar sobre este tema num encontro de estudos organizado por ele em Sestri Levante em 2005 (Platone politico nel Novecento in Aspetti della fortuna 
dell'antico nella cultura europea, a cura di E. Narducci, S. Audace e L. Fezzi, Pisa: ETS 2005, pp. 51-63).

Desejo agradecer aos amigos Walter Cavini, Franco Ferrari, Giovanni Giorgini, Francisco Lisi, Franco Trabattoni, Gherardo Ugolini e Federico Zuolo que me ajudaram a encontrar material bibliográfico pertinente. Agradeço também, pelos preciosos estímulos proporcionados pela discussão, os estudantes do Laboratório de História da Filosofia que realizei na Primavera de 2008 na Universidade de Pavia. 


\section{PLATÃO POLÍTICO}

\section{OS TEXTOS}

iógenes Laércio (III 50-51) insere a República (Politeia, ou "sobre o justo"), as Leis (Nomoi), o Minos, o Epinomis e o Crítias no elenco dos diálogos platônicos pertencentes ao gênero "político". Eliminemos logo da lista o Minos, certamente espúrio, e o Epinomis de Filipe de Opunte; é conveniente tirar também o Crítias que, de resto, o próprio Diógenes considera “ético" em outro lugar (III 60): trata-se provavelmente de um apêndice ao Timeu, e partilha a mesma enigmática ambiguidade que ele, declaradamente política mas, de facto, mais física (Diógenes considera o diálogo "físico") e teológica.

$\mathrm{Na}$ lista de Diógenes deve, sem sombra de dúvida, ser incluído o Político ( $D a$ realeza), que ele considera de gênero "lógico" (III 59). Sobram, portanto, três textos inequivocamente "políticos", aos quais se 
poderiam acrescentar grandes partes do Górgias e do Protágoras, todo o Menexeno, o Críton e a Carta VII, se a quiséssemos considerar autêntica. Mas, mesmo excluindo estas inserções, é logo evidente, já no plano quantitativo, o espaço ocupado pela reflexão política no corpus platônico.

De fato, as Tetralogias de Trasilo incluem 56 diálogos, 8 dos quais (inclusive as Epistolas) são certamente apócrifos. Ficamos com 48 e depois 45, se subtrairmos os três textos políticos. Somando ao Político os dez livros da República e os doze das Leis, obtêm-se 23 unidades dialógicas, mais de metade, portanto, de todo o corpus atribuível a Platão. Quanto basta, à primeira vista, para convencer-se de que os temas da política não eram decerto secundários no âmbito da sua reflexão. Os próprios títulos dão um testemunho bastante significativo disso: politeia significa em grego quer a estrutura "constitucional" de uma comunidade política, quer a extensão e composição hierárquica do corpo cívico, incluindo o direito de cidadania e de acesso aos cargos públicos (de fato, os dois significados tendiam a coincidir porque o que, por exemplo, distinguia uma constituição democrática de uma oligárquica era sobretudo esse direito). Quanto a Nomoi, trata-se evidentemente do conjunto legislativo que determina o funcionamento de um sistema constitucional; e o Político versa sobre a definição do tipo de homem a quem cabe o exercício de um poder eficaz no âmbito de um sistema político que ele é chamado a modelar.

A centralidade da questão política em Platão era, de resto, testemunhada pela edição do grande filólogo 
alexandrino Aristófanes de Bizâncio (séc. III a.C.) que, segundo afirma Diógenes (III 61-2), teria colocado a República em primeiro lugar, indicando, assim, uma ordem de leitura dos diálogos. É o caso de notar que a República, como de resto o Politico e as Leis, não tratam só de política em sentido estrito: mas, como veremos, a integração da política num quadro filosófico mais vasto é um traço típico do pensamento platônico, e isso não altera a centralidade de que se tem falado. Por outro lado, é igualmente verdade que os temas políticos são quase onipresentes nos textos de Platão, da Apologia ao Laques, do Fédon ao Fedro, além dos já mencionados Protágoras, Górgias, Menexeno e Criton.

\section{A BIOGRAFIA}

Sobre o papel que os interesses políticos desempenharam na experiência pessoal de Platão dispomos de um documento (auto?) biográfico excepcional: a Carta VII. Como se sabe, sobre a autenticidade deste texto há fortes dúvidas bem fundadas, e a questão provavelmente não tem solução no plano estritamente filológico. $\mathrm{O}$ que, pelo contrário, não parece ser objeto de dúvida é a sua fiabilidade biográfica: a Carta, se não é de Platão, deve contudo ser atribuída a um autor muito próximo dele, talvez Espeusipo ou um discípulo de Espeusipo que pudesse aceder a documentos acadêmicos em posse do mestre. Convém notar que, no que diz respeito às vicissitudes siracusanas, a exposição da Carta (que tem certamente propósitos 
apologéticos acerca das intenções que moveram Platão e os Acadêmicos) é confirmada essencialmente por Plutarco, que podia dispor de uma documentação independente. De resto, os historiadores são, em geral, mais propensos que os intérpretes filosóficos de Platão a reconhecer a fiabilidade do documento, porque não se encontram envolvidos pela discussão sobre o significado político do pensamento platônico que, como veremos, dominou a exegese da segunda metade do século XX (voltaremos a esta questão no Cap. 8).

As informaçóes essenciais que a Carta VII nos propóe acerca da atitude platônica quanto à política podem ser resumidas brevemente da seguinte forma:

1. Uma propensão inicial para a atividade política, absolutamente normal num jovem ateniense do século $\mathrm{V}$ a.C., nascido numa família de elevada condição social e de evidente vocação política, que continha personagens importantes, como os tios Pirilampo (de parte pericleia), Crítias e Cármides (que se destacariam no regime dos Trinta Tiranos): "Quando era jovem, partilhei uma paixão comum a muitos jovens: assim que alcançasse a minha independência, queria entrar na vida política da cidade" (324b).

2. A recusa a participar na tirania dos Trinta - pelos seus crimes - e a sucessiva desilusão para com a democracia restaurada, culpada, aos olhos de Platão, do processo e da condenação à morte do seu mestre Sócrates.

3. A convicção, adquirida depois destas experiências, da impossibilidade de uma intervenção pessoal nas vicissitudes políticas atenienses, e da extrema di- 
ficuldade em encontrar 'amigos' decididos a comprometerem-se em uma obra radicalmente reformadora, embora "continue a aguardar sempre o momento oportuno para a ação".

No final, apercebi-me de que todas as cidades de hoje são mal governadas (o seu sistema legislativo é praticamente incurável a não ser que se lhe dediquem extraordinários preparativos acompanhados de fortuna). E fui obrigado a dizer, elogiando a autêntica filosofia, que só ela consente que se identifiquem todas as formas de justiça no âmbito quer da vida política, quer da pessoal: as geraçōes humanas não serão libertadas dos seus males enquanto aquele tipo de homens que praticam a filosofia de modo autêntico e verdadeiro não chegarem ao poder político, ou aqueles que governam as cidades, por uma qualquer sorte divina, năo começarem a praticá-la (326a-b).

4. Por fim, a decisão de intervir mais do que uma vez na política siracusana (Siracusa era uma das maiores metrópoles do mundo grego e constituía um verdadeiro laboratório político, no qual, depois de uma experiência democrática, se afirmara um regime tirânico odiado mas prestigiado e eficiente, sustentado por Dionísio I). Com a escolha siracusana, Platão rompia definitivamente com a política ateniense: a cidade siciliana era uma inimiga tradicional dos atenienses, porque determinou a sua derrota na grande expedição de $415 / 3$, du- 
rante a guerra do Peloponeso, e contribuiu para a sua humilhação com a "paz de Antalcidas" de 387, imposta por Esparta e pela Pérsia e defendida por Dionísio.

As razões que levaram Platão a fazer a primeira viagem a Siracusa, em 388/7, podem apenas ser supostas: talvez, uma vaga esperança de induzir o tirano a adotar uma forma de governo inspirada nos princípios filosóficos da justiça, ou a intenção de encontrar um apoio influente para a fundação da escola ateniense de Platão, a Academia. Concluída a experiência com um total insucesso, Platão dedicou à Academia os sucessivos vinte anos da sua vida. Mas, em 367, com a morte de Dionísio I, sucedeu-lhe o filho , que o nobre siracusano Díon - considerado por Platão um dos melhores discípulos da Academia - reputava disponível à receção do ensinamento moral e político do mestre. As palavras com as quais o autor da Carta explica as motivações de Platão ao aceitar o insistente pedido de Díon devem ser referidas na sua totalidade, porque elas - largamente confirmadas por muitos textos dialógicos - contribuem de modo significativo ao esclarecimento da atitude do filósofo relativamente ao seu envolvimento político.

Se alguma vez se devessem tentar realizar as minhas conceções sobre as leis e a forma de governo, aquele era o momento para o experimentar: convencer um só homem ter-meia bastado para levar tudo a bom porto. Com estes pensamentos e com determinação zar- 
pei de Atenas, não pelos motivos que algumas pessoas me atribuíam, mas sim porque me teria envergonhado demais em ver-me como um homem só de palavras, e incapaz de comprometer-se em qualquer ação [...]. Parti então, seguindo razão e justiça por quanto é possível a um homem, abandonando por isso as minhas não indignas ocupaçóes, para ir ao encontro de uma tirania decerto não idônea nem aos meus discursos nem a mim mesmo (328b, 329a-b).

A nova expedição $(366 / 5)$ terminou num desastroso fracasso, pela rivalidade de Dionísio e Díon e pela recusa do tirano a reformar o seu domínio. $\mathrm{O}$ próprio Platão só conseguiu voltar para Atenas são e salvo graças à decisiva intervenção do pitagórico Arquitas, tirano de Tarento, com o qual Platão havia estabelecido uma relação de amizade. O filósofo realizou em 361 uma nova e igualmente inútil viagem a Siracusa, mais uma vez pelas insistências de Díon e talvez pelo mesmo Arquitas. Interrompem-se aqui, com a idade de cerca setenta anos, as suas tentativas de intervir diretamente na vida política (mas não a sua reflexão sobre o governo, visto que se dedicou à redação das Leis até os últimos dias de vida). Todavia, não há dúvida que Platão tenha pelo menos tacitamente autorizado a expedição militar a Siracusa em 357, comandada por Díon e por outros Acadêmicos e apoiada por Espeusipo, que se concluiu com a deposição de Dionísio II e com a subida ao poder tirânico de Díon. 
Se este foi o último episódio político que envolveu indiretamente Platão, a expedição siracusana constituiu, pelo contrário, o princípio de uma convulsa participação da Academia nas vicissitudes das poleis gregas e, sobretudo, das suas tiranias, na segunda metade do século IV. Mas esta é outra história, apesar de ela poder parecer indicativa da inspiração que de modo explícito ou implícito Platão transmitira aos seus discípulos.

\section{O QUE SIGNIFICA “POLÍTICA” EM PLATÃO?}

Até agora baseamo-nos na objetividade dos dados textuais e na relativa confiabilidade de uma (auto)biografia da qual não se deve esquecer a razão apologética. Responder neste texto introdutório à pergunta sobre o significado de "política" para Platão - resposta que constitui propriamente o prêmio do conflito das interpretaçôes de que se ocupará este livro - comporta, ao invés, o difícil esforço de se manter, por assim dizer, no grau zero da hermenêutica, para evitar formulaçōes de alguma maneira preconceituosas e prematuras. Tentaremos, então, oferecer algumas indicaçôes preliminares para definir o âmbito dos problemas em jogo sem prejudicar o seu sentido total.

1. O que interessa a Platão no campo dos "negócios da cidade", ta politiká, parece ser constituído por estes aspectos: o acesso aos cargos de governo; a finalidade do poder que esses cargos permitem; a obtenção do consenso; a estrutura econômico-social da cidade e as 
relações entre os grupos que a compõem; a preparação e a condução da guerra. Platão está menos interessado a grosso modo na engenharia constitucional e legislativa, ou nas estruturas institucionais que a realizam (sobre as quais se centra, ao invés, por exemplo, o interesse historiográfico de Aristóteles na Constituição dos Atenienses), embora estes aspectos sejam, de fato, tratados nas Leis.

2. O primeiro contato com a política tem, em linhas muito gerais, um caráter diagnóstico: há uma "doença da cidade" (poleos nosema, Resp. VIII 544c7). Esta doença ataca em primeiro lugar, mas não só, a cidade democrática de modelo ateniense: a crítica às mais difundidas formas políticas existentes (a democracia, a oligarquia e a monarquia absoluta ou tirania) é feita no livro VIII da República e retomada no livro III das Leis. O sintoma mais evidente da crise da cidade nesta época, do fracasso do projeto de civilização que os gregos tinham procurado seguir na sua história, é a duradoura fratura da polis em duas partes hostis e contrapostas entre si, "a cidade dos ricos e a cidade dos pobres" (Resp. IV 422e), cada uma delas fragmenta-se ulteriormente numa pluralidade de núcleos de interesse privados. A máxima aspiração da vicissitude histórica dos gregos - a construção de uma comunidade política unida, concorde e pacificada - nunca foi realizada e o seu fracasso tornou-se evidente nas vicissitudes históricas que serviam de fundo para a experiência pessoal de Platão (as staseis ou "conflitos civis internos", e aquelas guerras entre gregos que, por sua vez, devem ser consideradas guerras civis da comunidade helênica). 
O desmascaramento da crise e o diagnóstico da doença são confiadas por Platão não só ao "seu" Sócrates, que se põe de maneira explícita - até ao processo e à condenação - como antítese viva da degeneração da cidade, mas também ao testemunho, por assim dizer, “extraído" nos diálogos aos ideólogos da política, quer sejam democráticos, como Protágoras, "realistas" ou filotirânicos, como Polo, Cálicles e Trasímaco.

3. Uma crítica particularmente áspera é dirigida à democracia ateniense, aos seus maiores líderes como Temístocles e Péricles (cuja célebre oração fúnebre aos mortos em guerra, na versão atestada de Tucídides, é satirizada no Menexeno), aos procedimentos e aos modos de vida que a caracterizam (o sorteio dos cargos, o excesso de liberdade que degenera na anarquia). $\mathrm{O}$ essencial destas críticas é desenvolvido no Górgias e espelha-se nos livros VI e VIII da República, e ainda no livro II das Leis. O poder democrático, vítima da procura de consenso, transforma-se num ato demagógico que está a serviço dos piores desejos das massas ignorantes, em vez de as guiar para o bem comum da coletividade política.

4. Face a estas patologias, Platão propõe diversas estratégias terapêuticas que visam restabelecer a harmonia e a saúde das cidades. Trata-se, em geral, de uma distribuição dos papéis de governo que espelhe o dom psicológico dos diversos tipos de indivíduo presentes na comunidade política. Na República, essa distribuição dá lugar, segundo a terminologia de Dawson, a uma utopia de "baixo perfil", de inspiração dórica, nos livros II-IV, e a uma utopia comunista de perfil alto no livro V; 
nas Leis, trata-se pelo contrário de uma rígida delimitação do corpo cívico que atribui papéis de governo a um grupo restrito de cidadãos-chefes de família. Estas estratégias teriam o objetivo de garantir a unidade da cidade sob a forma de uma hierarquia dos papéis sociais, da concórdia interna do grupo dirigente, da aceitação do seu poder por parte das classes subalternas.

$\mathrm{Na}$ República, a proposta terapêutica apresenta-se em forma de um argumento de tipo condicional. Se quiser finalmente construir uma cidade governada com vista à felicidade pública, por conseguinte, unida, harmoniosa e pacificada, então será preciso, em primeiro lugar, redistribuir as funções sociais em relação às capacidades dos membros da comunidade. Deverá haver um restrito grupo de governo, capaz de comandar com vista aos interesses gerais, formado por indivíduos nos quais prevalece o princípio da racionalidade (logistikón); um grupo combatente, aliado e subordinado ao primeiro, constituído por aqueles em cuja estrutura psíquica prevalecem as motivações de autoafirmação agressiva (thymoeidés); por fim, um grupo de produtores (agrícolas e artesanais) e de comerciantes, do qual farão parte os indivíduos dominados pelo desejo de riqueza e de prazer (epithymetikón). A subordinação hierárquica, mas consensual, entre estes grupos deverá ser garantida graças a um trabalho de educação coletivo, por uma virtude comum, a sophrosyne ou moderação, e a sua colaboração será o sigilo da justiça finalmente realizada na cidade. Com base no axioma tipicamente platônico que aquilo que garante a unidade e a estabilidade da comunidade é a harmonia do 
grupo dirigente, será também preciso que este último seja defendido da tentação de exercer o poder no próprio interesse e não no poder do interesse geral. Se o grupo dirigente deve, pois, ser coeso e desinteressado, então é preciso que sejam negados aos seus membros quaisquer interesses privados, quer patrimoniais, quer afetivos. Os dois "escândalos" propostos no livro V da República consistem portanto na abolição da propriedade privada e da família: no interior do grupo dirigente deverão estar em vigor quer o comunismo dos bens, quer a comunhão de parceiros reprodutores e a criação coletiva da prole. O grupo dirigente deverá também ser minuciosamente selecionado e consolidado, quer através de ações educativas, quer através de uma política "eugênica" que junte constantemente os seus melhores elementos, como se faz na criação de animais de raça (esta política comporta uma mentira ditada pela "razão de estado", que faça passar a seleção reprodutiva como efeito de sorteios casuais; uma mentira semelhante, com objetivos propagandistas, fora exposta no livro III, onde se tratava de fazer crer aos cidadãos que a sua distribuição em diversos grupos sociais se devia a uma diferença da respectiva natureza originária, áurea para os governantes, argêntea para os combatentes, brônzea e férrea para os outros).

Tudo isto, diz Platão, é certamente contrário ao costume vigente, ao ethos tradicional, mas não à "natureza” (456c), como é confirmado pela igualdade de papéis e de funçôes entre os machos e as fêmeas dos cães de caça e de guarda. Certamente aquele ethos será radicalmente apagado, junto com todas as leis vigen- 
tes nas cidades históricas: a medida mais drástica proposta por Platão é a expropriação inicial dos lugares de governo a todos os membros da comunidade que tenham mais de dez anos e tenham sido educados segundo a tradição existente, e a sua destinação aos trabalhos agrícolas (VII 541a) até serem reeducados consoante a nova estrutura da cidade.

Isto, reafirma mais de uma vez Platão, é necessário se quiser obter a cura da cidade; é indubitável que se trata de uma terapia de difícil realização, todavia não impossível (VI 499d e passim), porque seria ridículo que se tratasse apenas de "castelos de nuvens" (V 456c e passim). Saber depois qual é, segundo o autor, o estatuto das terapias da cidade delineadas por Platão projetivas, utópicas, irônicas, éticas além de, ou mais que, políticas - é questão controversa no jogo hermenêutico, e, por conseguinte, deve, pelo menos por ora, ser deixada de lado.

5. Dado que a questão do poder (a pergunta “a quem cabe o governo?") é central nas estratégias platônicas, igualmente decisivo mostra ser o problema da identificação das figuras às quais cabe o papel ativo na reforma, em suma, identificar quem pode agir como médico da cidade doente, segundo a metáfora eficaz na qual insiste o Político (296b segs.). Trata-se, segundo o livro V da República, de uma elite de "filósofos", intelectuais de elevados dons intelectivos e morais, cujo lugar de 'incubação' não é arbitrário detectar na Academia platônica, ou então, de um só "verdadeiro político" ou "homem real", dotado de uma ciência política que lhe consente prescindir da legislação 
escrita, cuja chegada é dada como hipótese no Político, ou ainda de um "filho de um dinasta", ou então de um bom "jovem tirano", disposto a converter-se à filosofia, ou, melhor, a aceitar o conselho de um legislador filósofo, de quem se fala no livro VI da República, no IV das Leis, e que, talvez, seja indicado na figura de Dionísio II, ou de Díon na Carta VII. Por fim, pode tratar-se dos astroteólogos membros do "Conselho Noturno" que devem controlar o respeito à constituição previsto no livro XII das Leis. Sobre estas figuras todas, sobre a sua plausibilidade teórica e sobre a sua possibilidade política, valem naturalmente as mesmas interrogações formuladas no parágrafo anterior, e o seu sentido deve ser aqui igualmente deixado de lado.

6. A questão das estratégias terapêuticas e da sua realização eficaz varia, quer se trate de curar uma cidade existente, quer de prevenir o surto de patologias sociais numa nova fundação. $\mathrm{O}$ primeiro caso tem, por sua vez, duas variantes: se tratar de uma cidade de regime democrático, com base no modelo ateniense, é relevante a utilização de instrumentos de boa retórica para a persuasão das massas, aos quais se faz alusão no livro VI da República e que são tematizados no Fedro, ou, então, a questão da instauração, mesmo coercitiva, de uma nova forma de poder; no caso das cidades com regime tirânico, como Siracusa, o problema é, ao invés, o da educação-conversão do tirano ou de um filho seu que mostre ter disposição para tal.

No segundo caso, é, pelo contrário, decisiva a obra do consulente legislador relativa aos fundadores da nova cidade: é a tarefa que, nas Leis, o estrangeiro atenien- 
se assume para com os colonos da futura Magnésia; e é legítimo supor que um semelhante papel tenha sido desempenhado pelo próprio Platão e pelos membros da Academia em diversas cidades da Grécia do século IV, ou que esperassem desempenhá-lo.

7. Qualquer regime político, por mais próximo que esteja da perfeição, está porém destinado à crise e à transição para outras formas. Isto deve-se, em primeiro lugar, à instabilidade ontológica estrutural da época histórica e à instabilidade estrutural antropológica da natureza humana, natureza esta exposta - apesar dos condicionamentos educativos - à pressão das componentes irracionais do eu e, além disso, às contradiçôes que são inevitavelmente inerentes a qualquer sistema de governo. Esta tese de fundo é defendida de várias formas no livro VIII da República e no III das Leis, e a ela se alude no mito do Político; no primeiro destes textos, ao contrário do que ocorre nos outros dois, não se faz nenhuma menção a um possível andamento cíclico da temporalidade histórica. A fenomenologia histórica da República prevê, portanto, uma degeneração da justiça da "bela cidade" (kallipolis) na "timocracia" (poder da ambição e da força), na oligarquia (poder da riqueza), na democracia (poder dos desejos anárquicos), até chegar ao regime desprezível da tirania, que comporta a escravidão universal dos homens sob o domínio de um tirano, também ele escravo dos seus desejos. A transição para os diversos regimes é devida às contradições internas específicas de cada indivíduo, e não se indica especificamente nenhuma saída da tirania. 
O que até aqui se delineou constitui, como se disse, um quadro mínimo meramente informativo do âmbito sobre o qual versa a reflexão política de Platão, e sobre as suas variáveis modalidades. Este quadro resultaria, contudo, já deformado e desviante se não fosse acrescentado um esclarecimento necessário. Nenhum texto platônico se destina em modo exclusivo à discussão das questôes políticas, ta politiká, como, por exemplo, faz a Política de Aristóteles, nem isto seria possível por causa do estilo total da filosofia de Platão.

A política, porém, pressupóe uma antropologia e esta funda-se numa psicologia. Mas a psicologia platônica pode, por sua vez, ser de tipo fenomenológico e, por conseguinte, "político" - como declaradamente é a psicologia do livro IV da República e, em parte também, a psicofisiologia do Timeu - ou metafísico, colocando então no centro a questão da imortalidade - como a do Fédon, com as suas ramificações mitológicas relativas ao tema da reencarnação, exemplo do que sucede no livro X da República e em outros lugares.

Por outro lado, a política está intimamente interligada a uma ética, porque a sua tarefa consiste na instauração da justiça no mundo humano. Mas a ética platônica - preocupada evidentemente com a garantia de absoluto e a objetividade do plano dos valores contra o relativismo sofístico e a arbitrariedade do poder - não pode prescindir de uma ontologia, que é primariamente a das ideias-valores, precisamente as ideias do justo e do bom. Por sua vez, a colocação metaempírica das ideias de valor impõe a questão da sua cognoscibilidade, a qual requer a construção de uma epistemologia relativa 
ao plano noético-ideal. A estrutura da filosofia platônica pode, pois, ser representada como um triângulo, em cujos vértices têm verdade, ser e valor (tanto ético como político) e cujo perímetro pode ser traçado, consoante os casos, a partir de qualquer um dos vértices.

Onipresente em Platão, a dimensão política nunca pode, portanto, ser isolada dos outros âmbitos que a fundam e a orientam, e este aspecto filosófico decisivo pode contribuir por si mesmo para explicar as incertezas exegéticas e o vastíssimo leque das interpretações que marcaram a tradição do "Platão político". Trata-se agora de dar conta desta tradição e das suas matrizes genealógicas.

\section{NOTA BIBLIOGRÁFICA}

Para a atribuição da Carta VII a Espeusipo ou ao seu círculo, cf. fidedignamente M. I. FINLEY, Plato and Pratical Politics, in Id., Aspects of Antiquity, Harmondsworth: Penguin 19772, pp. 74-87; propen-de para a sua autenticidade o recente estudo de L. BRISSON (éd.), Platon. Lettres, Paris: Flammarion, 1987, pp. 133-66.

Toda a documentação sobre o envolvimento político de Platão e da Academia se encontra recolhida e é discutida em K. TRAMPEDACH, Platon, die Akademie und die zeitgenössische Politik, in "Hermes - Einzelschriften", 66, Stuttgart 1994. Sobre o problema, $c f$. os estudos de M. ISNARDI PARENTE, Filosofia e politica nelle Lettere di Platone, Napoli: Guida, 1970, e L'Accademia antica e la 
politica del primo ellenismo, in G. Casertano (a cura di), I filosofi e il potere nella società e nella cultura antiche, Napoli: Guida, 1988, pp. 89-117; $c f$. recentemente M. VEGETTI, Filosofia e politica: le avventure dell'Accademia, in F. L. Lisi (ed.), The Ways of Life in Classical Political Philosophy, Sankt Augustin: Academia, 2004, pp. 69-81. Uma recapitulação histórica das vicissitudes siracusanas no século IV encontrase em F. MUCCIOLI, Dionisio II, Bologna: CLUEB, 1999.

Sobre a crítica de Platão aos regimes políticos existentes, $c f$. L. BERTELLI, Platone contro la democrazia (e l'oligarchia), in CR VI, 2005, pp. 295-396; J.-F. PRADEAU, Platon, les démocrates et la démocratie, Napoli: Bibliopolis, 2005.

Para o "triângulo" platónico e uma sintética apresentação do estilo da filosofia de Platão $c f$. M. VEGETTI, Quindici lezioni su Platone, Torino: Einaudi, 2003. A distinção citada entre os níveis da utopia em Platão é de D. DAWSON, Cities of the Gods. Communist Utopias in Greek Thought, New York-Oxford: Oxford University Press, 1992. Uma equilibrada apresentação introdutória do pensamento político de Platão encontra-se em M. SCHOFIELD, Plato. Political Philosophy, Oxford: Oxford University Press, 2006.

Aqui e noutros lugares, os sete volumes de M. VEGETTI (a cura di), Platone. Repubblica, traduzione e commento, Napoli: Bibliopolis, 1996-2007, são indicados com a abreviatura CR seguida do número do volume e do ano de publicação. 


\section{NAS ORIGENS DA INTERPRETAÇÃO}

\section{ARISTÓTELES: O CÂNONE DA CRÍTICA POLÍTICA}

eve-se a Aristóteles a primeira e a mais drástica
operação de isolamento dos temas propriamente
políticos da trama complexa do pensamento platôni-
co. Conduzida com precisão cirúrgica, a operação é
imposta pelo critério de pertinência disciplinar com
base no qual Aristóteles distribui o saber dos seus pre-
decessores na redação dos tratados que compõem a
unidade articulada da sua enciclopédia. Assim, a dis-
cussão efetuada sobre as opiniōes precedentes no livro
II da Política, em particular as da República e as das
Leis de Platão (o Polititico não é mencionado), focaliza-
se sobre os aspectos daquelas obras que mostravam ser
precisamente de pertinência política, quebrando os
elos de ligação, muito cerrados como se viu nos textos
platônicos, com as dimensōes da psicologia, da ética, 
da ontologia, da epistemologia e da teologia. No final da sua exposição da República, Aristóteles acrescenta, sem esconder demasiado o seu incômodo: "Quanto ao resto, Sócrates encheu o seu discurso de argumentos não pertinentes e de discursos sobre a educação dos governantes" (Pol. II 61264 b39 segs.).

O que sobra propriamente de político no grande diálogo? Este é o sumário que dele oferece Aristóteles: 1. a comunhão de mulheres e filhos; 2. a comunhão das propriedades; 3. a ordenação dos cidadãos em duas grandes classes, os "agricultores" e os combates, e a sucessiva seleção, no interior destas classes, de um grupo de governo, "senhores" (kyrios) da cidade; 4. a participação das mulheres nas mesmas funções dos governantes (phylakes), inclusive na guerra, e no mesmo tipo de educação (II 61264 b29 segs.).

Este resumo (baseado essencialmente em parte dos livros IV e V da República) apresenta uma omissão e algumas imprecisões ou incertezas. A omissão diz respeito ao caráter "filosófico" do grupo de governo (os célebres filósofos-reis do livro V). Ela pode ser explicada de duas maneiras, não alternativas. Ao redigir o seu sumário, Aristóteles cinge-se fundamentalmente ao resumo da República que o próprio Platão havia formulado no início do Timeu (17a-19a), no qual a figura dos filósofos-reis já havia desaparecido: então por que não seguir uma omissão operada pelo próprio autor, ainda por cima numa obra tardia em que ele apresentava novamente o essencial do seu diálogo político? Ou então, pode-se recorrer mais uma vez ao critério de pertinência: de um ponto de vista político 
o que conta é a existência de uma pequeníssima elite de governo selecionada no interior do grupo combatente; neste contexto pode parecer irrelevante o conteúdo da sua formação e do seu saber (precisamente aqueles "discursos sobre a educação" que a Aristóteles pareciam estranhos à política, embora, com efeito, segundo Platão fosse precisamente o saber filosófico a legitimar o direito ao poder do grupo dirigente).

Pelo contrário, imprecisão e incerteza dizem respeito ao "comunismo" dos bens. Na República, Platão não falara de comunhão das propriedades, mas sim de recusa da propriedade por parte do grupo de governo na cidade; tinha também circunscrito explicitamente a este grupo a forma de vida comunitária. Aristóteles, ao invés, parece alargar a propriedade comum ao inteiro corpo social, mesmo aludindo ao fato que sobre este ponto Platão não teria dito "nada de preciso" sobre a forma de propriedade dos agricultores (II $51264 a 14$ segs.). Também esta aparente incompreensão da República tem todavia uma explicação. Nas Leis, voltando ao assunto do primeiro diálogo político, o mesmo Platão falara de uma propriedade coletiva da terra, o que poderia fazer pensar em uma interpretação "autêntica" da República em termos de uma comunhão de bens alargada a todo o corpo social (Leg. V 739c-740a).

Assim delimitados e englobados os conteúdos políticos da República, Aristóteles pode proceder à sua revisão crítica, não sem lhes atribuir um elogio de tom irônico. "Uma legislação como esta apresenta à primeira vista um aspecto agradável e um caráter filantrópico: quem ouve a sua exposição fica bem disposto, pensando que 
ela produzirá uma maravilhosa amizade de todos com todos" (II 51263 b15 segs.). Trata-se, porém, de uma ilusão que Aristóteles se empenha a dissipar, montando o seu formidável dispositivo crítico. Este dispositivo acerta no alvo em dois pontos: o primeiro propriamente politológico, o segundo antropológico.

Platão teve certamente razão ao identificar a unidade da cidade como objetivo da sua reforma política. Mas ao perseguir esta finalidade, ultrapassou o limite, confundindo a desejável unidade política com a que é própria da família ou até do indivíduo (II 2 1261a15 segs.). A crítica de Aristóteles não é privada de fundamento. De fato, no livro V da República dizia-se que a comunidade onde todos podem dizer "meu" e "não meu" acerca das mesmas coisas, até chegar a sentir juntos "as mesmas experiências de dor ou de prazer", acabaria por apresentar o mesmo grau de unidade de um só indivíduo, em que a dor no dedo era sentida como propriamente de todo o organismo (462c-d). Mas, observa Aristóteles, a comunidade política funda-se na colaboração de uma pluralidade de indivíduos diversos por capacidade e por recursos, os quais, exatamente por estas diversidades interagem na troca recíproca de bens e serviços; é precisamente esta troca entre diversos que permite à comunidade política um nível de "autossuficiência" superior ao da família e ao do indivíduo. A symphonia política não pode ser transformada em homophonia (II 51263 b29 segs.). O projeto platônico, que pode parecer à primeira vista "belo mas impossível” (II 3 1261b31), na realidade não é sequer desejável, porque nega a essência pluralística da 
cidade; mesmo que fosse possível, não deveria ser realizado (II 2 1261a18 segs.). "É portanto evidente que por natureza não pode existir uma cidade tão unida como alguém defende, e que aquilo que é apresentado como o máximo bem nas cidades é exatamente aquilo que as destrói” (II 21261 b6 segs.).

De resto, o modelo platônico produziria uma contrafinalidade. Estando destinado a superar a divisão da cidade em dois campos contrapostos (os ricos e os pobres), acaba, pelo contrário, por impedir a alternância dos cidadãos no governo, dividindo a polis em uma classe dotada de poder, outra à qual cabem as armas, e a terceira que é privada permanentemente do poder, com o inevitável efeito de um ressentimento social e com o consequente conflito interno, que oporia a segunda e a terceira classes à primeira (II 51264 b6 segs.). Virando ironicamente ao avesso a tese platônica, Aristóteles conclui que "numa única cidade haverá forçosamente duas cidades, e contrapostas uma à outra” (II 51264 a24 segs.).

Estas objeções de cunho político fundam-se numa crítica ainda maior e mais radical de ordem antropológica, que confirma a marca de indesejabilidade, além da impossibilidade, atribuída ao desenho político da República.

A figura social em que se baseia a sociedade política segundo Aristóteles é o cidadão proprietário e chefe de família (o oikonomos). A crítica a Platão nasce da irredutibilidade antropológica deste autônomo indivíduo proprietário enraizado na estrutura do oikos privado, no qual a República operava uma negação sistemática. 
Numa sociedade coletivista como a platônica, afirma Aristóteles, não haveria nenhum cuidado com tudo o que - bens e pessoas - provém de propriedades comuns. "Presta-se pouquíssima atenção ao que é comum a muitos: com efeito, ocupa-se muito com as coisas privadas, menos com as comuns, e destas só na medida em que digam respeito aos indivíduos" (II 3 1261 b33 segs.). Este dado de fato intransponível acabaria por dizer respeito também aos "filhos" comuns da cidade platônica: se "cada cidadão se acha na situação de ter mais outros mil cidadãos como filhos [...], no sentido que qualquer um deles é filho de qualquer cidadão, acabarão por descuidar de todos da mesma maneira" (1261b38 segs.); de fato, "tal como pouco vinho doce misturado com muita água torna imperceptível a mistura, o mesmo acontece também com as relaçôes de parentesco, porque numa comunidade tal é inevitável que o pai se preocupe pouco com os chamados filhos, o filho se preocupe pouco com o pai e os irmãos uns com os outros" (II 41262 b17 segs.). Os dois objetos primários do cuidado e da afeição (tanto no plano parental, como no plano patrimonial) são, com efeito, "o próprio e o amado", isto é, pode entender-se o que é amado enquanto próprio.

A destruição do oikos predita pelo modelo platônico tornaria, contudo, impossível a ligação fundamental de amizade (philia), porque ela não pode existir sem reconhecimento parental e vínculos familiares. Nessa cidade não poderiam sequer existir alegria e prazer, porque a fonte de "prazer inenarrável” é precisamente poder considerar qualquer coisa como 
"própria”, na esfera privada dos afetos e patrimônios (II 5 1263a40). Portanto, ninguém seria feliz na cidade platônica: nem os cidadãos excluídos do poder e das suas honras, nem os governantes aos quais são negadas justamente as alegrias do "meu" atribuídas à privacidade da posse (II $51264 \mathrm{~b} 15$ segs.). Ninguém poderia sequer ser virtuoso: a falta de bens privados torna impossível praticar a generosidade e a liberalidade do dom; a falta de vínculos matrimoniais impede a temperança sexual. Aliás, a cidade platônica corre o risco de se transformar em cena de uma tragédia edipiana universal pela difusão de parricídios e de incestos tornados inevitáveis pela impossibilidade de se reconhecer as relações de consanguinidade (II 4).

Aristóteles pode então concluir - com uma afirmação que teria encontrado inúmeras adesões na tradição - que na cidade platônica "a vida parece ser de todo impossível” (II 5 1263b9). Trata-se de um projeto tão impossível como indesejável (portanto, não deve ser realizado mesmo que se mostrasse possível realizá-lo), porque ele entra em conflito com a natureza humana, com os pilares de qualquer sistema social. Aristóteles acrescenta às críticas de ordem política e antropológica uma contraprova, de teor, por assim dizer "historicista”. Na longa duração do tempo passado, um modelo do gênero não teria escapado aos homens, se realmente fosse válido: "de fato, pode-se dizer que tudo foi descoberto, mas algumas coisas nem sequer foram concebidas, outras, mesmo conhecidas, não foram postas em prática” (II $51264 \mathrm{a} 2$ segs.). O juízo da história confirma portanto o da natureza: as ideias de 
Platão são inaplicáveis quer na ordem temporal, quer na dos valores políticos.

Mas em que consistiria a raiz do erro de Platão, o erro que entregava o seu projeto à atopia, ao alheamento relativo à ordem da natureza humana e da sua história? A resposta de Aristóteles é clara e, no fundo, constitui a matriz de todas as variantes de reformismo. Platão quis transformar radicalmente a estrutura social da propriedade, com consequências políticas e antropologicamente avassaladoras. Os mesmos efeitos desejáveis que ele visava podem, pelo contrário, ser obtidos integrando "o ordenamento atual" da propriedade privada no plano moral e legislativo, "com bons costumes e um conjunto de leis corretas" (II 521 segs.), que prescreverão um certo grau de comunhão dos frutos da propriedade (uso comum de alguns bens, extensão dos mesmos aos amigos, etc.) (II 530 segs.). "É absurdo", conclui Aristóteles, "que exatamente aquele que propunha introduzir a educação na cidade e pensava torná-la boa graças a ela, creia depois reformá-la recorrendo a semelhantes meios [abolição da família e da propriedade privada], em vez de confiar-se ao melhoramento dos costumes, à filosofia e às leis, como sucede em Esparta e em Creta, onde o legislador pôs em comunhão os frutos da propriedade através das refeições em comum" (II 51263 b37 segs.). Em suma, com os instrumentos de uma violenta transformação das bases sociais, Platão perseguiu aqueles resultados que se podiam obter mediante uma reforma educativa e legislativa dos costumes privados e públicos, emendando assim os defeitos do egoísmo da propriedade 
e os da separação excessiva entre ricos e pobres (mas aqui Aristóteles ignora a crítica que Platão dirige no livro VIII da República ao caráter inevitavelmente oligárquico e socialmente conflitual de sociedades como a espartana e a cretense).

Seja como for, Aristóteles concluía assim, decisivamente, uma reflexão crítica sobre a República que, sem dúvida, já devia ter decorrido no interior da Academia e devia ter produzido uma parcial reconsideração por parte do velho Platão nas Leis, um diálogo que, pelo menos em parte, tinha em conta quer a discussão acadêmica quer, talvez, as objeçôes do mesmo Aristóteles. Aqui Platão continuava a reconhecer como melhor o modelo delineado na República, com a sua intenção de "desenraizar absolutamente da vida tudo o que se define privado", coletivizando até aquilo que é "privado por natureza", como os olhos, as orelhas, as mãos, com o fim de se obter a visão, a audição, a ação conjunta. Mas agora Platão reconhecia que uma comunidade semelhante era talvez mais idônea a ser habitada por "deuses ou filhos de deuses", admitindo que tudo isto "excede as atuais $\{$ nun $\}$ condições de nascimento, de criação e de educação"; mostrava-se, portanto, inevitável regressar a um modelo de cidade onde se reconhecesse o caráter privado das terras, casas e famílias, embora submetido a um cerrado controle legislativo (V 739c-740a). Com efeito, relevava Platão, antecipando de perto a prescrição aristotélica de que se falou, que se houver algo que possui o mais alto grau de beleza e de verdade, mas se mostrar todavia "impossível”, o legislador deverá recusá-lo e não realizá-lo 
(746c). Certamente entre Platão e Aristóteles sempre existira uma diferença de princípio: a renúncia platônica ao paradigma da República estava condicionada àquele nun, "por ora", enquanto que, em Aristóteles, a sua renúncia se fundava sobre o "sempre" invariante da natureza humana, que é impossível e impensável de se pôr em questão. De qualquer maneira, também a revisão efetuada pelo mestre nas Leis parece a Aristóteles demasiado parcial e, por conseguinte, insatisfatória.

A maior parte das Leis está dedicada a leis singularmente tomadas, e pouco se diz a propósito da constituição; e apesar de ele querer elaborar uma que tenha mais aspectos em comum com as cidades existentes, acaba pouco a pouco por voltar àquela outra constituição. Excluindo a comunhão de mulheres e de propriedades, de resto, prescrevem-se as mesmas coisas para ambas as constituições: a mesma educação, a mesma forma de vida alheia aos trabalhos necessários, e o mesmo se dá com as refeições comuns (Política II 6 1265a1 segs.).

Aristóteles dirige a Platão a acusação de ter feito exatamente aquilo que ele dizia que o legislador devia evitar: "Devem-se propor hipóteses segundo o que aparece desejável, nada porém que se mostre impossível" (II 61265 a17 seg.). A crítica de Aristóteles ataca mais uma vez as que nas Leis lhe parecem ser tentativas de incisão na estrutura socioeconômica da polis, tal como a limitação do número das famílias e da 
entidade dos patrimônios. Quanto aos aspectos propriamente políticos, as Leis propóem evitar os erros da democracia e da oligarquia, mas acabam por delinear uma constituição que contém elementos de ambas, apesar de se orientar mais para uma forma de regime oligárquico (II 6 1266a7).

Os traços salientes da crítica formidável de Aristóteles ao pensamento platônico podem agora ser esquematicamente recapitulados: 1. Aristóteles não tem dúvidas quanto à pertinência política das propostas constitucionais delineadas na República e nas Leis; 2. não duvida sequer que para o seu autor a realização destas propostas era desejável e de alguma maneira possivel; 3. não considera, pelo contrário, o conjunto do projeto platônico desejável, nem realizável, porque não é capaz de resolver no plano político os problemas reais das cidades e porque se contrapõe aos dados estruturais e invariantes da natureza social do homem.

Alguns séculos depois de Aristóteles, Cícero - o grande vetor da tradição do pensamento político grego em ambiente latino - teria retomado os momentos centrais da sua crítica a Platão, de quem, a seu modo, se declarava herdeiro, escrevendo por sua vez um De republica e um De legibus. Da República, Cícero recusava em primeiro lugar o comunismo patrimonial, sustentando, com Aristóteles, que se devia salvaguardar a propriedade privada, salvo violação do ius humanae societatis, mas usar livremente dos seus frutos em comum (De officiis I 20-22, 42); e odiava ainda mais a abolição da família e dos laços parentais: 
Então não haverá nenhuma distinção de sangue nem nenhuma descendência segura, nem família, nem parentesco, nem afinidade, mas tudo deverá ser confuso e indistinto como nos rebanhos de animais, nem haverá nenhuma continência nos homens, nem pudor nas mulheres? [...] Que infelicidade será a de uma cidade onde as mulheres usurparão as ocupaçôes dos homens? (De rep. fr. IV.5, ed. L. Ferrero-N. Zorzetti).

(Ao que diz Epicteto, parece que as mulheres romanas confirmavam a invetiva retórica de Cícero: "Em Roma as mulheres têm em punho a República de Platão, porque defende que as mulheres devem ser em comum", Mem. fr. 15).

Mas mais importante que a previsível recusa do comunismo platônico por parte de um tenaz defensor da ideologia da classe senatorial romana como Cícero é a sua reformulação da crítica "historicista" já proposta por Aristóteles. Afirma Cipião no diálogo De república:

Ser-me-á mais fácil realizar o meu objetivo, se puder mostrar-vos o nosso estado no seu nascer, crescer, tornar-se adulto e, finalmente, sólido e forte, em vez vos apresentar um completamente abstrato [finxero], como fez Sócrates nas obras de Platão (II 3) [...]. Ele procurou e imaginou uma cidade mais para fantasiar que para aguardar [optandam magis quam sperandam], a mais pequena possível, não como poderia ser, mas para ilustrar a sua 
teoria política. Eu, pelo contrário, tentarei [...] não esboçar o perfil imaginário de um estado, mas esforçar-me-ei, ao falar de um estado fortíssimo, por fazer manifestar [...] a causa de todo o bem e de todo o mal político (II 52) (a partir da tradução italiana de D’Ippolito).

É da concreta vicissitude histórica do estado romano que o Cipião ciceroniano quer retirar os elementos fundadores da sua teoria política, ou seja, daquilo que - teria dito Aristóteles - no tempo foi pensado e experimentado, e não pelo pensamento visionário de um filósofo, por maior que ele tivesse sido. O estado romano, na sua concreta evolução, constitui o exemplar, o paradigma real, tanto daquilo que de positivo é desejável e possível, quanto daquilo que de negativo aparece evitável.

Por fim, deve ser acrescentado que Cícero não tem dúvidas também quanto à crítica final de Aristóteles. A justiça não pode consistir, em primeiro lugar, nas leis da comunidade política: o seu fundamento primeiro está na moralidade individual dos cidadãos, naquele ethos privado que Platão parecia ter negligenciado ao conceder a primazia à reforma estrutural da sociedade.

A posição de Cícero destinava-se a ter uma imensa influência no pensamento da renascença, e a sua sombra teria acompanhado, como veremos, os primeiros passos da República no Ocidente latino. 


\section{PROCLO: A HERMENÊUTICA}

\section{DA DESPOLITIZAÇÃO}

De Albino a Jâmblico, a República (para não falar das Leis) foi excluída do cânone dos diálogos platônicos que eram lidos e comentados nas escolas do platonismo de idade imperial (isto é, na época do médio e neoplatonismo). O cânone incluía dez textos introdutórios (do Alcibiades I ao Filebo), para terminar depois no estudo dos dois diálogos considerados vértices da especulação do mestre, o Timeu e o Parmênides. A República, sobretudo nos seus livros centrais dedicados à ideia do bem e à dialética, era certamente conhecida dos filósofos neoplatônicos, mas - quer pela sua amplitude, quer pela temática predominantemente política - não estava no centro dos seus esforços exegéticos e de sistematização didática. Mais relevante era, por conseguinte, a exceção representada pelos comentários dedicados ao diálogo por parte de um grande platônico do século V como Proclo: trata-se, de todo o caso, do único comentário antigo da República que nos chegou em forma quase integral.

É altamente importante, no âmbito do percurso hermenêutico que estamos a investigar, compreender a estratégia interpretativa desenvolvida por Proclo em relação ao grande diálogo político, além da sua inevitável e por vezes forçada inserção no quadro sistemático da metafísica neoplatônica (a identificação de bem e uno, a escala das hipóstases do intelecto à alma, a complexa teologia procliana, etc.). 
Deve-se dizer logo que, apesar de tudo isto, Proclo não põe de todo em discussão o caráter político da República. Identificando o seu skopos, o seu sentido global, ele nega que se possa separar, como parece que alguém tivesse feito, o tema da justiça do da politeia: ele insiste que os dois aspectos estão conectados em Platão por um vínculo de implicação recíproca (Diss. I, 11.5 segs.). Ou melhor, são reafirmados os carateres salientes da "ciência política" em Platão: as suas propostas pertencem ao âmbito do possivel (dynatón) conjuntamente com o do útil (ophelimon), sendo portanto praticáveis como desejáveis (Diss. VIII, 238.1521). Sobre este terreno Proclo está atento em assinalar a diferença entre a República e as Leis. Porque é que pergunta-se ele, no segundo diálogo: as mulheres não participam nos cargos do governo? A resposta é precisa e talvez integre uma parcial omissão platônica. As Leis mostram-se axiologicamente inferiores à República porque elas apresentam um grau inferior de unidade do corpo social, recusando a posse comum dos bens e reestabelecendo o aspecto privado dos interesses (Diss. IX, 256.23-257.1). Dado que as mulheres parecem estar mais apegadas à dimensão privada, sobretudo familiar, quando esta se encontrar presente, não é um bem as mulheres governarem, visto a sua propensão para antecipar os interesses privados aos comuns (257.2-6).

Igualmente interessante e pontual é a resposta de Proclo às críticas que Aristóteles dirigira ao desenho da utopia platônica. A unidade da cidade, que segundo Aristóteles, Platão tinha levado ao excesso, des- 
truindo a natureza pluralista, a mesma da comunidade política, que deve ser interpretada não em sentido "material” (que faria da cidade uma "coisa” só), mas em sentido formal-final (telikón), isto é, como primariedade de funções e de valor do todo em relação às partes (aqui é inevitável em Proclo o apelo à cosmologia do Timeu, com o privilégio ligado à harmonia do "Todo" em relação aos elementos que o compõem) (Diss. XVII, 360-365). Quanto à objeção aristotélica segundo a qual ninguém está propenso a ocupar-se das coisas comuns, Proclo replica que ela (tal como outras críticas semelhantes) pode ser verdadeira para quem tenha vivido com os costumes vigentes, mas não se refere a homens educados, segundo o projeto platônico, a privilegiar o bem comum da cidade (368).

Seguindo esta linha, o filósofo neoplatônico chega até, contra Aristóteles, a formular com grande clareza aquilo que ficaria a ser o princípio fundamental do comunismo de todas as épocas históricas: "Os bens serão comuns a todos dado que, ao pertencerem todas as coisas à cidade, cada um obtém o necessário em relação à sua necessidade" (366.6-7).

Há todavia, na exegese de Proclo, um ponto de encontro, que estava destinado a desempenhar um papel importante na história das interpretações da República. Comentando a analogia alma-cidade que estrutura o livro IV do diálogo, Proclo estabelece sem hesitações uma prioridade axiológica e ontológica do primeiro termo sobre o segundo.

As virtudes e os vícios das partes da alma pré-existem, por assim dizer, como modelos 
[paradeigmata] para as virtudes e os vícios inatos nos gêneros políticos. De fato, agindo do interior, virtudes e vícios dispõem as partes da alma de modo melhor ou pior, enquanto que, dirigindo-se para o exterior e convertendo-se em ações, dão ordem aos gêneros políticos ou enchem-nos de desordem (209.6-13). [...] Todas as formas de governo [...] são relações, mas as exteriores são imitaçôes [mimeseis] das inferiores e atividades secundárias em relação às primárias, e $a$ autêntica arte política diz respeito às formas de governo interiores [...] como a arte política própria dos gêneros políticos entendidos como imagens [eikones] é também imagem daquela autêntica (Diss. VII, 210.25-30, cf. também 217.10-15).

A dimensão externa, política, visto que é mais visível, constitui uma via para aceder à cognoscibilidade das condições internas da alma de que é "imagem" (210.17-20), mas mostra-se subalterna e derivada delas. Proclo não desfaz o nó platônico entre alma e cidade, mas dispóe as duas polaridades em ordem hierárquica e mimética em vez de em uma relação circular de interação. Como se verá no Cap. 8, este ponto de vista teria - é difícil dizer se de modo direto ou indireto - uma influência relevante nas estratégias hermenêuticas do século XX que pretendem negar, ou relegar para o segundo plano, a dimensão política da República fazendo disso uma metáfora dos problemas morais da alma individual (basta antecipar aqui os 
nomes de Annas, Blössner, Ferrari, que partilham de maneiras diversas uma interpretação deste gênero).

Além desta incipiente "moralização" do diálogo, outras e mais gerais aproximações exegéticas de Proclo eram destinadas a uma duradoura influência.

Trata-se, em primeiro lugar, da sua leitura sistematizadora, isto é, que pretende estabelecer relaçôes não problemáticas entre a República e outros diálogos considerados fundamentais pelos neoplatônicos, como o Fédon e o Timeu, além, como se disse, do fundo metafísico-teológico próprio do neoplatonismo (assim, na Dissertação IX a paridade entre homens e mulheres defendida no livro $\mathrm{V}$ é fundada na paridade de virtudes de deuses e deusas, e, na Dissertação VII a função do filósofo-rei torna-se a do mediador entre a unidade do Bem e do Todo e a pluralidade das vicissitudes humanas).

Depois há sobretudo na Dissertação $I$, a propósito da descida de Sócrates ao Pireu e da festa em honra da deusa Bêndis, uma forte torção do texto platônico em sentido simbólico-alegórico, que acabaria por marcar profundamente as leituras renascentistas que se fizeram da República.

Por fim, deve ser assinalado um aspecto interessante da sensibilidade exegética de Proclo, o que hoje se chamaria aproximação dialógica. Para explicar porque é que no livro VI da República Platão fala do Bem sem identificá-lo explicitamente com o Uno, segundo os critérios da metafísica neoplatônica, coisa que Platão fez no Parmênides (pelo menos segundo a interpretação que lhe fora atribuída já por Plotino), Proclo escreve que isso se deve, em primeiro lugar, à presença 
de personagens como Trasímaco e Clitofonte: Sócrates "não considera oportuno revelar os mais profundos mistérios (ta mystikotata) na presença de sofistas". Mais em geral, a reticência socrática deve ser explicada relacionando-a com a não preparação dos interlocutores, inclusive Gláucon: "se os homens fossem adequados a discursos daquele nível, ele ter-nos-ia enchido de muitos discursos autenticamente teológicos sobre o Bem" (Diss. XI, 274.1-11). Também aqui é o caso de adiantar que a falta de sistematicidade por reticência dialógica acabaria por constituir no século XX um dos cânones interpretativos da escola de Tübingen, e que esta reticência acabaria, por outros motivos, por ser o centro da leitura de Leo Strauss.

O texto grego do comentário de Proclo, há pouco reaparecido no Ocidente, foi consultado e parcialmente traduzido para o latim por Marsilio Ficino, em 1492. Desde então, não mais cessou de acompanhar a República, influenciando diretamente a sua leitura (devido a Ficino) em época renascentista, e continuando depois a agir de modo latente mas não insignificante, ao longo de toda a história da sua interpretação.

\section{IDADE MÉDIA E RENASCIMENTO: DA ALEGORIA À TEOLOGIA}

Os textos políticos de Platão não foram traduzidos para o latim durante toda a Idade Média. A cultura medieval conheceu apenas alguns ecos da República: aqueles transmitidos pelo breve resumo oferecido pelo 
Timeu (um dos poucos diálogos traduzidos e estudados) e sobretudo aqueles oferecidos pela polêmica aristotélica no livro II da Politica. Ambos os testemunhos insistiam nos aspectos mais embaraçosos da $R e-$ pública aos olhos de um leitor cristão: a comunhão das mulheres, a abolição da família, o comunismo dos bens. Dado que eram avessos a pôr em discussão um grande auctor antigo como Platão, ainda por cima considerado (graças ao Fédon) um precursor do cristianismo, aos mestres medievais não restava outra solução senão reinventar uma estratégia hermenêutica, em parte já adotada por Proclo (também ele desconhecido dos medievais). As inquietantes teses platônicas serão portanto interpretadas como defesa per involucrum, in tegumentum (Bernardo de Chartres, Abelardo), em suma, como metaphorice loqui (Egídio Romano): o tratamento alegórico e metafórico consentia, em qualquer caso, que se reduzisse o aspecto escandaloso do pensamento platônico, e se encontrasse forçosamente uma compatibilidade qualquer com a filosofia cristã.

A República regressou ao Ocidente latino só em 1402 em Pavia, graças à tradução devida ao trabalho conjunto de um funcionário da corte dos Visconti, Uberto Decembrio, e de um doto bizantino em missão diplomática, Manuele Crisolora. Nesta primeira reaparição, é interessante notar o predomínio de um interesse político para com o grande diálogo: o experimento inovador da senhoria milanesa procurava no diálogo, de certa forma, uma legitimação a opor àquela que a Política aristotélica havia oferecido durante séculos, primeiro ao regime feudal, depois a repúblicas 
oligárquicas como Florença e Veneza. Para Uberto era bem claro o caráter normativo da República (Platão "rempublicam ordinavit quo ordine condenda esse censeret") que ele contrapunha, seguindo o testemunho de Macróbio, ao processo descritivo do diálogo homônimo perdido de Cícero (que teria, ao invés, explicado "qualiter a maioribus fuerit instituta"). Uberto não tinha dúvidas quanto à intenção política da $R e$ pública; notando, todavia, a sua distância dos "costumes públicos" vigentes, apesar de tudo ele se declarava mais próximo de Aristóteles, embora continuasse a considerar "possíveis" as propostas platônicas.

Muito diferente era a atitude do filho de Uberto, Pier Candido, que cinquenta anos depois da obra do pai propôs uma tradução anotada da República: Pier Candido já devia ter em conta quer as críticas provenientes do ambiente cultural florentino, em particular de Leonardo Bruni, quer das perplexidades suscitadas em ambiente eclesiástico devidas à leitura do livro $\mathrm{V}$ do diálogo (os arcebispos de Cartagena e de Milão mostravam-se indignados pela "impudicissima lex" sobre a comunhão de mulheres).

O título dado à obra já não era só Politia, como em Uberto, mas Celestis Politia, que retomava o "paradigma no céu" de que Platão havia falado no livro IX da República (592b), e que iniciava a leitura em chave de ideal utópico irrealizável na terra. De fato, explicava Pier Candido, Platão tinha querido propor uma cidade não humana, mas divina e celeste, "votis magis quam rebus expetenda" (ou seja, exatamente aquela euche, aquele "pio desejo", que Platão tinha querido excluir considerando-o "ridículo", VI 499c). 
Nesta ótica - não obstante Pier Candido continua a aludir a uma certa proximidade da cidade platônica, pelo menos na forma timocrática, à senhoria dos Visconti - torna-se possível reler a comunhão dos bens à luz da pobreza dos santos, em referência à Igreja primitiva. No seu esforço por cristianizar a República, o tradutor humanista reativa em parte a leitura alegórica, sub enigmate, dos intérpretes medievais; por exemplo, acerca do mito da reencarnação do livro X ele avisa o leitor "hanc partem mistice esse positam et aliter a Platone intelligi quam ad litteram legatur". Outras passagens - e aqui a leitura de Pier Candido também adianta correntes interpretativas modernas de peso devem ser interpretadas como escritos ironice. Entre utopia, alegoria e ironia, se podem justificar muitos dos aspectos desagradáveis da política platônica e torná-los aceitáveis ao paladar cristão.

Em finais do século XV, este percurso é concluído por Marsilio Ficino, com as suas Epitomes de 1484 e os comentários de 1496, textos nos quais se insere a leitura do comentário de Proclo recém-descoberto (1492). Ficino move-se por duas vertentes. Por um lado, como escreveu Cesare Vasoli, ele "reduz ao mínimo indispensável a exegese e a inevitável apologia do discurso político de Platão", vendo na República um puro modelo teórico, o ideal de uma cidade contemplativa virada para "ad verum investigandum, deumque colendum". À luz desta ideia, Ficino faz remontar a comunhão de mulheres e de bens a uma longa tradição, que inclui gimnosofistas, pitagóricos, essênios e até os santos fundadores da Cristandade; o 
seu objetivo, argumenta Ficino contra os críticos de Platão, consiste em libertar os homens das discórdias mundanas e dos interesses terrenos para que se dirijam às atividades do espírito. Quanto ao governo dos filósofos, ele teria sido realizado anteriormente pelo povo mais antigo e sábio, os egípcios (que estavam nas origens daquela prisca theologia de que Platão teria sido o prossecutor). Por outro lado, a leitura de Ficino da República é completamente orientada para um sentido teológico (ajudada mais uma vez pelo recurso à hermenêutica alegórica), que tem no seu âmago a identificação da ideia do bem com Deus; Ficino reconduz pois o diálogo ao percurso da interpretação de Proclo, ao qual acrescenta o tema especificamente renascentista da pertença de Platão a uma tradição de sapiência antiquíssima e iniciática.

O encontro de Ficino com a República, mediado pela redescoberta de Proclo, estava destinado a ter uma secular e profunda influência na leitura do Platão político, no sentido de uma sempre mais marcada espiritualização e relativa despolitização. No que concerne aos conteúdos propriamente políticos do diálogo, apesar dos esforços de Ficino para atenuar o seu impacto, teria prevalecido em todo o Renascimento uma atitude de dura condenação, como a que foi formulada por Jean Bodin, o qual na sua République (I 2) considerava o comunismo platónico "contraire à la loy de Dieu et de nature" (embora, para dizer a verdade, não faltassem defensores, de Gemisto Pletone a Patrizi). 
Para as interpretações do Platão político no pensamento antigo, de Aristóteles a Agostinho, $c f$. os ensaios agrupados em M. VEGETTI, M. ABBATE (a cura di), La "Repubblica" di Platone nella tradizione antica, Napoli: Bibliopolis 1999. Para a crítica aristotélica a Platão, $c f$. também M. VEGETTI, CR IV, 2000, pp. 439-52. O comentário à República de Proclo pode ser agora lido na tradução (com amplo comentário) ao cuidado de M. ABBATE: Milano: Bompiani, 2004.

Para a Idade Média e o Renascimento, $c f$. os ensaios agrupados em M. VEGETTI, P. PISSAVINO (a cura di), I Decembrio e la tradizione della "Repubblica" di Platone tra Medioevo e Umanesimo (onde aparece o ensaio de Vasoli sobre Ficino leitor da República), Napoli: Bibliopolis, 2005. É fundamental, também, J. HANKINS, Plato in the Italian Renaissance, 2 vols., Leiden: Brill, 1990. Para a época moderna é importante A. NESCHKE-HENTSCHKE, Platonisme politique et théorie du droit naturel, vol II, Louvain-Paris: Peeters, 2003. 
3.

\section{OS PARADIGMAS DA MODERNIDADE}

\section{KANT: OS IDEAIS DA RAZĀO}

$\mathrm{O}$ encontro de Kant com o pensamento ético-político de Platão dá-se em poucas, mas densas e iluminadoras páginas da Crítica da Razão Pura (Dialética transcendental, livro I, secção I, Das ideias em geral, pp. B 370-5 da edição de 1787 , ao qual se deve unir o livro II, cap. III, seção I, $O$ ideal em geral, pp. B 595-9). A intenção que leva Kant a efetuar esta rápida revisão do pensamento platônico é a de identificar o significado originário da palavra "ideia": não por uma investigação estritamente filológica, mas através de uma discussão "crítica", visto que o pressuposto metodológico kantiano é que seja possível "compreender um autor melhor do que ele se compreenderia a si mesmo”. Tratar-se-á portanto de perceber o que são verdadeiramente as ideias platônicas, quais são as suas 
condições de validade e também o que não podem ou não deveriam ser.

As ideias representam a exigência da razão de ultrapassar o nível conceitual que produz a unidade sintética dos fenômenos, "demasiado além" para que os objetos da experiência possam corresponder-lhes (kongruieren), mas possuem todavia uma própria Realität e não são redutíveis a simples quimeras "extravagantes".

Aqui Kant discorda de Brucker, e precisamente esta polêmica desvia o discurso da questão das ideias em geral para o seu âmbito ético-político, que se exprime de maneira específica na República. O grande historiador luterano, na sua Historia critica philosophiae, editada pela primeira vez em 1742 - que segundo alguns constitui a única ou principal fonte de conhecimento do pensamento platônico para Kant -, tinha tentado sobretudo desmascarar erros e contradições dos filósofos, para combater aquilo que defendia o "pestilentissimum auctoritatis praeiudicium", mostrando assim os limites insuperáveis da razão humana e a consequente necessidade de se recorrer à fé na revelação divina. A ele se deve a crítica implacável ao caráter "quimérico", além de escandaloso nos seus conteúdos, da República platônica: uma república inventada (fictam) que podia existir "só no cérebro de Platão", com o seu idealístico fanaticismus (I, pp. 726-7).

A crítica de Brucker causa a indignação de Kant e induzo a esclarecer o sentido da ideia no espaço da ética e da política, partindo de uma dura polêmica antiempirista que acerta num alvo importante mas não declarado: as objeçōes de Aristóteles a Platão no livro II da Política. 
A República, escreve Kant, "tornou-se proverbial como suposto exemplo de perfeição sonhada tal que não residiria senão na mente de um pensador ocioso" (a partir da tradução italiana de Chiodi modificada). Mas, acrescenta, "não a devemos rejeitar com o pretexto pueril e nocivo da sua impossibilidade de realização [Untunlichkeit]". A réplica kantiana merece ser citada na totalidade, porque de certa forma se mostra definitiva.

Por mais atinente que seja aos princípios da moralidade, da legislação, da religião - no âmbito dos quais, são as ideias a tornarem primeiramente possível a própria experiência (do bem), embora não seja possível que encontrem aí uma plena expressão -, Platão adquiriu um mérito especial que não é devidamente reconhecido, porque o julgam com base em regras empíricas, cuja capacidade de servir de princípios devia, ao invés, ser destruída exatamente pelas ideias [...]. Em relação às leis morais, a experiência (infelizmente) é mãe da aparência [Schein], e é extremamente reprovável deduzir as leis do que devo fazer [Ich tun soll] partindo daquilo que é feito [getan wird], determinando o primeiro com base no segundo.

Como se vê, a drástica distinção kantiana entre fato e valor, ser e dever ser, ataca decididamente, na esteira de Brucker, o prudente conservadorismo aristotélico nos seus pilares naturalistas e "historicistas". De fato, usam-se como modelos de virtude os que são apenas 
eventuais exemplos dela, faz-se da própria virtude "uma equívoca irrealidade, mutável segundo os tempos e não utilizável como regra”. Segundo Seung, Kant reconhece aqui em Platão o pai do "transcendentalismo normativo", em oposição ao "positivismo normativo", que reconhece os padróes normativos em fatos sociais como leis positivas ou moralidade convencional.

Quais são, então, as funçôes autênticas e imprescindíveis das ideias? Elas desempenham, segundo Kant, um papel regulador, que se exerce em dois níveis: como critérios do juízo de valor, padrão de avaliação moral, por um lado, como fim ou telos da práxis, por outro. A primeira função implica a segunda: "a ideia serve necessariamente de fundamento [Grunde] para cada aproximação à perfeição moral". Nunca nenhum objeto da experiência poderá ser perfeitamente adequado à regra, isto é, ao padrão avaliador, nem poderá realizar completamente a finalidade da práxis éticopolítica: estes objetos não podem, portanto, servir de "arquétipos" (Urbilder), mas, na melhor das hipóteses, podem servir de provas aproximadas da factibilidade (Tunlichkeit) daquilo que a ideia da razão requer.

No campo prático existe uma verdadeira causalidade da razão: enquanto critérios de avaliação e horizontes de finalidade, as ideias desempenham o papel de "causas eficientes". Fora deste âmbito, Kant recusa-se a seguir Platão, quer no terreno insidioso do Timeu, que parece atribuir às ideias uma causalidade também física e natural, quer ao conferir um estatuto ideal às matemáticas; ele também não pode aceitar a "dedução mística" das ideias partindo de uma inteligência 
divina, por via da reminiscência, ou os "exageros" (como a hipóstase hiperurânia das ideias) e a "elevada linguagem" pela qual se deixa levar o velho filósofo. Parecem ecoar aqui as irônicas palavras ("que extraordinário exagero! [daimonia hyperbolé]"), com as quais já Gláucon comentava a enfática descrição da ideia do bem na República (VI 509c).

Segundo Kant, é melhor circunscrever a causalidade das ideias, "principalmente em tudo o que é prático, isto é, fundado na liberdade", entendendo-se a liberdade de julgar e de agir consequentemente. $\mathrm{Na}$ Crítica, Kant não diz de modo explícito que a kallipolis platônica constitua, em sentido próprio, um "ideal da razão", mas este desenvolvimento pode ser facilmente subentendido, visto que o ideal é aí definido como uma ideia in individuo, isto é, como algo singularmente determinado por meio da ideia (neste caso, da ideia de virtude ou de justiça). De resto, isto é confirmado no texto $\mathrm{Se} o$ gênero humano está em constante progresso para o melhor: "A comunidade que, concebida segundo conceitos racionais puros, se chama um ideal platônico (respublica noumenon), não é uma quimera sem sentido, mas é a norma eterna de cada constituição civil em geral", portanto, um arquétipo apto a fazer com que a constituição das sociedades humanas se aproxime progressivamente da maior perfeição possível. Um ideal, reafirma Kant, que se refere aqui à figura exemplar do sábio estóico, que nunca é completamente reproduzível e adequável, mas isso não implica que ele não forneça à razão um indispensável critério de juízo, e não se constitua em norma e regra para o aperfeiçoamento moral. A tal se 
opõe a chamada política "prática", que considera a ordem constituída o bem supremo (mas o seu governo é considerado por Kant o "pior despotismo que se possa imaginar").

Kant não tem nenhuma dúvida - diferentemente do que pensam muitos intérpretes contemporâneos acerca da pertinência do modelo platônico para o âmbito político: ele representa o ideal regulador de uma "constituição que pretende fundar a liberdade humana máxima possível com base em leis tais que façam com que a liberdade de cada um coexista com a dos outros" (o objetivo não é pois a imediata felicidade máxima, mas ela acontecerá necessariamente, por si mesma, a partir de tal constituição).

O problema que permanece aberto é outro. Kant é claríssimo acerca do papel avaliador e da causalidade eficiente e final do paradigma platônico sobre a conduta moral e a factualidade política. O que Kant, ao contrário, não diz é por que são precisamente os conteúdos daquele paradigma - isto é, os lineamentos constitutivos da kallipolis - a desenvolverem o papel formal de ideal transcendental que lhe foi reconhecido. Admitindo que cada realização sua se deva mostrar inevitavelmente parcial e imperfeita, porque é que aquela "norma eterna" de cada constituição possível deveria prever a abolição da propriedade privada e da família (pelo menos para o grupo de comando), o domínio de uma elite intelectual, a exclusão da maior parte dos cidadãos das funções de governo? Há uma conexão necessária entre estes conteúdos e o papel normativo do ideal platônico? 
Kant não parece estar interessado em responder a estas questôes (sobre elas se concentrará, como veremos, a interpretação hegeliana). A sua extraordinária precisão conceitual ao distinguir normas de fatos, ao atribuir ao projeto platônico o seu papel ideal não imediatamente transferível à práxis, mas ainda avaliador e orientador relativamente à mesma práxis - portanto, absolutamente não "quimérico" - teria exercido uma grande influência na exegese platónica (pelo menos a partir de finais do século XIX). Mas o seu silêncio sobre a relação entre dimensão formal e dimensão de conteúdo da teoria normativa de Platão teria deixado aberto, para esta exegese, um vasto terreno de discussão e também de dissensão.

\section{HEGEL: O “ESPÍRITO DO TEMPO”}

Ao contrário de Kant, Hegel dispunha de um conhecimento mais amplo e em primeira mão dos textos platônicos. Se, não obstante isto, também a sua atenção se concentra sobre a República, com escassas menções às Leis e ao Político, é provável, então, que isso se deva a motivos de ordem teórica (como se verá, o segundo diálogo podia parecer demasiado "demiúrgico", o primeiro demasiado dedicado a "receitas" legislativas).

Ao contrário de Kant, Hegel está, antes de tudo, empenhado em negar o caráter "quimérico" e "extravagante" da República. Mas a estratégia e o sentido teórico da defesa de Platão da acusação de Brucker mostram-se radicalmente antitéticas em relação às te-ses 
kantianas. Se nelas prevalecia o caráter formal do ideal regulador proposto por Platão, para Hegel tratava-se, ao invés, de recusar a acusação em nome do caráter substancial dos conteúdos do modelo platônico, agora considerados mais descritivos que normativos; com esta mesma atitude aparecem imediatamente negados quaisquer caráteres projetivos da República.

Nesta ótica, a de Brucker e de Kant, a "quimera" e o "ideal" acabam por ser duas faces da mesma moeda, dois aspectos do mesmo "vazio". Na República, diz Hegel nas Liçôes de história da filosofia, Platão apresentou um "apelo ideal de constituição política, que se tornou proverbial como uma Quimera [...] no sentido que esta representação poderá existir na mente" de um filósofo ocioso, e será realizável na condição de os homens serem excelentes, como os que vivem na Lua, mas não na terra: tratar-se-ia portanto de um "ideal completamente supérfluo". Se uma ideia é demasiado boa para existir, acrescenta Hegel, "então o defeito está no próprio ideal". Mas "quando um ideal tem em geral uma verdade íntima por meio da ideia, do conceito, então não é uma Quimera, mas é verdadeiro; e um tal ideal não é de todo algo ocioso, fraco [Kraftloses], mas é o real [das Wirchliche]. O verdadeiro ideal não deve [soll] ser real, mas é real" (pp. 272-4). Portanto, só uma má interpretação da República faz com que seja considerada um "ideal vazio", escrevera Hegel nos Lineamentos de filosofia do direito (Prefácio, $\mathrm{p}$. XIX), trocando-a por "uma fantasia [Träumerei] do pensamento abstrato, por aquilo que frequentemente se costuma chamar um ideal” $(\$ 185)$. 
De fato, a Hegel parece de todo absurda a ideia de um filósofo-legislador a quem caberia a tarefa de "realizar o ideal na história" e, com ela, a função demiúrgica que Platão parecia (por um equívoco interpretativo) ter atribuído aos seus filósofos-reis. "Para uma constituição não basta a teoria, não são os indivíduos a fazer uma constituição: ela é algo de divino, espiritual, historicamente necessário [ed. G.-J.]. E é algo de tão forte que o pensamento de um indivíduo não significa nada perante esta potência do espírito do mundo [Macht des Weltgeistes]" (LSF, p. 177). Hegel menciona dois célebres exemplos de reis considerados filósofos: um exemplo negativo porque ineficaz, o de Marco Aurélio, e outro positivo, o de Frederico II da Prússia. Ele elevou a "princípio inteiramente universal o bem do seu Estado"; em seguida, nos estados modernos, sem necessidade de filósofos-reis, mostrou-se verdadeiro o sentido autêntico da exigência platônica, isto é, "todo o âmbito político deve ser dominado por princípios universais" (LSF, pp. 195-6).

Nem sequer a filosofia pode dar conselhos ou "receitas" sobre pormenores legislativos: "A filosofia pode eximir-se de dar bons conselhos; Platão podia evitar recomendar às amas que não estivessem paradas com as crianças, mas embalassem-nas sempre nos braços" (LFD, Prefácio, p. XX). Aqui o sarcasmo de Hegel ataca a minuciosidade legislativa das Leis, tal como antes se dirigira à ambição demiúrgica do suposto criador de constituiçōes. A filosofia, se é boa filosofia, como é o caso da de Platão, não deve "construir um Estado tal como deve ser [wie er sein soll]", mas "compreender 
conceitualmente o Estado como algo em si racional" (ivi, pp. XXII).

Não há portanto nenhuma eficácia política da filosofia. A sua reflexão versa sempre sobre realidades histórico-políticas (por conseguinte, espirituais) já realizadas na sua maturidade que avança dialeticamente para o declínio: o que a filosofia pode fazer é transformar estas realidades em figuras do saber absoluto (no nosso caso, o estado) e é precisamente o que Platão fez, se o interpretarmos superando o equívoco do caráter quimérico-ideal da República.

Longe de propor ideais reguladores "vazios", aos quais a realidade tem de se adequar, Platão,
de fato, expôs a ética grega na sua modalidade substancial. A vida política [Staatsleben] grega é o que constitui o verdadeiro conteúdo da República platônica. Platão não é homem para se entreter com teorias e princípios abstratos: o seu espírito verídico conheceu e expôs a ver- dade, a qual não podia ser outra coisa senão a verdade do mundo em que vivia, este úni- co espírito vivo e presente tanto nele quanto na Grécia [G.- J.: im seinem Volk]. Ninguém pode ir além do seu tempo: o espírito do pró- prio tempo [der Geist seiner Zeit] é também o próprio espírito ( $L S F$, p. 275$)$.

A realidade (Wirchlichkeit) deste espírito apareceu a Platão na sua "verdade suprema, isto é, como organismo estatal [Staatsorganismus]" (p. 269), em que se atualiza a "ética substancial" do povo (pp. 277 seg.). 
Hegel identifica a filosofia platônica com o espírito comunitário da civilização grega, compreendida e descrita na sua realidade substancial pela filosofia. $\mathrm{Na}-$ turalmente, Hegel está atento a realçar que esta "realidade", imediatamente convertível em "racional", não se identifica com o dado empírico-fenomênico na sua mudança. Trata-se portanto de compreender a "verdade", a substância, sob a crosta de vícios e paixões individuais e passageiros ( $L S F$, p. 274). Platão não escreve uma história da Grécia, mas leva este estrato substancial da sua realidade à compreensão filosófica.

Aqui age claramente em Hegel a pré-compreensão classicista e idealizada da polis grega - que ele havia formulado nos anos em que estivera em Jena -, da sua "bela liberdade", da "virtude antiga que tinha o seu significado preciso e seguro, porque possuía um fundamento pleno de conteúdo na substância do povo e propunha como fim um bem efetivamente já existente" (por essa razão, uma virtude que ele contrapunha ao "pomposo discorrer" sobre a virtude dos modernos que pretende opor-se de maneira vã ao "andamento do mundo": Fenomenologia do espirito, C. AA. V B9).

Hegel tem, então, que ignorar o fato de que o próprio Platão havia considerado as suas propostas contrárias aos costumes tradicionais, parà to ethos (Resp. V 452a7), e havia defendido que a unidade da polis nunca fora realizada, dado que a cidade continuava a estar dividida em duas partes, a dos ricos e a dos pobres, contrapostas como num tabuleiro de xadrez, e que, além disso, cada uma delas estava despedaçada numa pluralidade de interesses particulares (IV 422e seg.). 
Hegel deve ainda, e sobretudo, esquecer a perturbadora discussão sobre a "possibilidade de realização" da kallipolis que se desenvolve nos livros V e VI da República. Aparece, assim, a suspeita de um círculo vicioso: Platão não propõe um "ideal”, mas compreende uma "realidade"; todavia, a correspondência entre a filosofia platônica e esta realidade torna-se possível somente se a segunda for, por sua vez, idealizada, e é precisamente esta idealização a esconjurar a idealidade da República.

Em todo o caso, esta coincidência entre "racionalidade" platônica e "realidade" da polis serve, no movimento do pensamento de Hegel, a superar o classicismo, marcando o limite dialético de ambas. Este limite emerge claramente da exposição hegeliana dos conteúdos positivos da República.

São reconstruídos com precisão os três pilares, tais como emergem dos livros IV e V do diálogo: a subdivisão do corpo social em três ordens (Stände), que Hegel considera não uma dedução platônica, mas um "sistema necessário em cada Estado" (a primeira ordem é descrita como sendo capaz de governar no interesse comum, logo, mais de acordo com a linguagem do livro IV que com a do livro V, porque Hegel obviamente não deseja realçar a realeza dos "filósofos"); a abolição da propriedade privada; a paralela supressão da família. Convém notar que Hegel não hesitou em considerar o coletivismo platônico estendido à inteira sociedade da polis, não obstante uma secular tradição de "defensores" de Platão ter realçado a sua restrição só aos grupos de governo. Hegel não se apoia em re- 
ferências textuais - no livro V da República e no V das Leis - que pudessem justificar esta interpretação; a universalização do coletivismo no conjunto "real" constituído pela República e pela polis grega é decisiva para ele, dado que representa ao mesmo tempo a verdade substancial da época e o seu limite dialético.

A propriedade privada e a família são, de fato, as fortalezas do "princípio da liberdade subjetiva" ( $L S F$, p. 292): e é precisamente a exclusão deste princípio que constitui quer "um traço fundamental da República platônica" ( $L S F$, pp. 288 segs.), quer o caráter substancial da "mesma ideia ética grega" que considerava o individualismo o princípio da corrupção dos estados, do ethos público, do seu espírito comunitário (Gemeinsamen Geist) (LSF, pp. 278, 288, 292-5).

Trata-se de um ponto de vista "substancial" e precisamente por isso relativo ao tempo, incapaz de acolher aquele princípio da liberdade subjetiva que assomará só mais tarde, com o cristianismo, no cenário mundial (apesar do prelúdio socrático, intempestivo e, por isso, destrutivo) ( $L S F$, p. 278). Este "defeito de subjetividade" marca o limite dialético da época dos gregos e, com ela, o limite da época da Staatverfassung platônica que aparece degradada à "posição subordinada", porque não pode "satisfazer a exigência superior de organismo ético", que consiste precisamente na conciliação dialética do princípio de estado com o de liberdade individual: uma conciliação que pertence só à época dos modernos e, por isso, ao seu pensamento.

Neste novo quadro, a propriedade privada e a família são "necessárias, ou melhor, sagradas"; além dis- 
so, a segunda oferece às mulheres a sua "destinação essencial”. Quanto aos Stände, Platão negou aos indivíduos, consequentemente, a liberdade de escolher a própria ordem, confiando aos governantes a escolha da colocação de cada cidadão nas classes; porém, ao contrário das castas indianas, nesta destinação não conta o nascimento ( $L F D, \$ 206)$.

Não obstante a diferenciação hegeliana, pode ser que nesta menção se encontre a origem da infeliz definição que Marx propôs da República como "uma idealização ateniense do sistema egípcio das castas" ( $O$ capital, livro I, a partir da tradução italiana, p. 410), permitindo-se, assim, ignorar este eventual precedente do pensamento comunista, primitivo ou utópico, mas, justamente por este motivo mal visto pelo fundador do "comunismo científico".

Voltando a Hegel, a força da sua interpretação - capaz de incorporar a tradição classicista e de refutar a suspeita de utopismo quimérico e de idealismo "vazio" que pesava sobre Platão, mas ao mesmo tempo de superar uma e o outro, mostrando o seu limite dialético em relação à modernidade - teria certamente influenciado a história das sucessivas leituras do platonismo político.

Mas uma influência talvez igualmente grande, do conceitualismo hegeliano seria exercida pela sua linguagem, ainda mais eficaz porque capaz de agir de modo aparentemente neutro, isto é, independentemente das opçóes filosóficas. Trata-se decerto de uma linguagem em boa parte não inventada por Hegel, mas que se mostra poderosamente codificada no uso filosófico que ele fazia dela. 
Bastará exemplificar esta tese com algumas palavras pesadas, com alguns efeitos de tradução destinados a configurar, ou a desfigurar, de modo duradouro a imagem de Platão. A primeira destas palavras é evidentemente Staat, com a qual Hegel traduz quer Politeia, como título da República, quer polis, que é o seu objeto. Em ambos os casos uma tradução imprópria. Politeia vale em grego seja composição do corpo cívico (portanto, direito de cidadania), seja, também, estrutura constitucional, forma de governo de cada comunidade; quanto a polis, é bem sabido que o termo designa uma comunidade política soberana, mas privada de aparelhos que, também segundo Hegel, definem um estado como os corpos separados da burocracia, da magistratura, do exército, da instrução. A tradução oculta, então, a sua referência à dimensão específica da politicidade que é intrínseca à linguagem grega (basta pensar numa tradução da definição aristotélica do homem como zoon politikón que a explique da seguinte forma: "o homem é um animal estatal"). A segunda palavra é Volk. Certamente ela não traduz o grego demos, que no uso platônico designa sempre uma parte política e social da cidadania (o mesmo em demokratia, "poder dos pobres"); quanto a ethnos, trata-se de um termo alheio à dimensão da polis, frequentemente referido às povoaçóes bárbaras. É claro que se for referido à comunidade de cidadãos, à koinonia politiké, Volk desloca a sua semântica do âmbito político ao da consanguinidade e da pertença territorial. A terceira palavra, por fim, é Geist. Não é necessário insistir sobre o fato de que ela não traduz logos (intrinsecamente 
conectado à dimensão comunicativa e argumentativa da linguagem) nem nous, que designa uma modalidade específica do pensamento, de tipo intuitivo e intensivo.

Então, quando Hegel escreve que o objeto da República é das griechische Staatsleben, ou o Staatsorganismus, que Platão é intérprete do "Geist vivo nele como no Volk da Grécia", da "substância ética do povo" como "todo vivo orgânico [eine lebendig organische Ganz]", ele inscreve o pensamento político de Platão, mesmo independentemente das suas intençóes, numa rede conceitual que condicionará por muito tempo quer a sua interpretação, quer a gama de avaliaçóes contrapostas.

ENTRE KANT E HEGEL:LIBERALISMO

E SOCIALISMO

OS GRANDES HISTORIADORES: ZELLER, GROTE, GOMPERZ

Com Eduard Zeller, cuja monumental Filosofia dos Gregos conheceu uma existência feliz que se estendeu por mais de meio século (da primeira edição de 1844-52 à quinta de 1922), o Platão político entrava no domínio da grande historiografia acadêmica e "científica" do século XIX (mas não por isso neutro ou indiferente relativamente aos problemas ideológicos e políticos).

Zeller não esconde a profunda inspiração hegeliana do seu contato com a República e com o pensamento político de Platão, e utiliza a sua linguagem, 
traduzindo sempre polis por Staat. Todavia, nele agem também a influência da ética kantiana e a do pensamento liberal (como veremos, porém, de ambiente mais prussiano-guilhermino que anglo-saxão).

Segundo Zeller, Hegel tinha razão sobretudo em negar que Platão propusesse "um irrealizável quadro de fantasia”; aliás, na República davam-se indicações precisas sobre a sua necessidade, possibilidade e realização. Por isto, "não se pode pôr em dúvida que tomasse realmente a sério todas as suas propostas" (pp. 637 seg., 640). Seguindo ainda Hegel, Zeller lê em Platão a reação do "espírito grego" face à separação dos indivíduos do estado e ao arbítrio individualista que comportava a sua ruína, que se teriam manifestado plenamente durante aquela crise de época que foi a guerra do Peloponeso. Esta reação exigia que os indivíduos fossem subordinados pela força à estrutura estatal (p. 644).

Mas Platão, segundo Zeller, tinha ido ainda mais além da ética hegeliana imediata da vida estatal grega. Apesar de Zeller (ao contrário de Hegel) reconhecer agora que a abolição da propriedade privada e da família, o "comunismo" dos bens e dos afetos se limitavam à elite dirigente da polis utópica, tudo isto não podia ser considerado expressão daquele Zeitgeist. Platão operava, então, uma radicalização extrema, em sentido elitista, que Zeller associa quer à sua biografia, quer à sua filosofia. Do primeiro ponto de vista, age o ideal aristocrático de Platão, o seu desprezo pelo trabalho manual e pelas massas populares: "como autêntico aristocrático, Platão despreza tão profundamente o trabalho material [...] para esperar dos que 
se dedicam a esse tipo de trabalho a bravura política e militar necessária aos seus guardiōes” (pp. 592 seg.). À orientação aristocrática devem ainda ser atribuídas as simpatias platônicas pelo opressivo regime espartano, com as suas formas de vida comunitária e de domínio do estado sobre os indivíduos. Zeller formulou tão completamente a primeira crítica de caráter "ideológico" e classista a Platão, que teve grande impacto na sucessiva historiografia de orientação marxista.

Mas é na filosofia que Zeller reconhece as raízes mais profundas da política platônica: mais precisamente naquele dualismo ontológico que contrapóe as ideias ao mundo empírico, o conhecimento verdadeiro dos poucos às flutuantes opiniōes das massas. E, então, "como seria possível que uma coletividade correspondente à ideia se constituísse a não ser através do domínio absoluto daqueles poucos privilegiados?" (p. 645). Consequentemente, "Platão pensa que não se possa esperar que instituições estatais razoáveis encontrem um acesso na população sem constrição" (p. 586), e muito menos que a "massa dos homens se submeta voluntariamente a este domínio” (p. 645).

$\mathrm{O}$ aristocratismo social por um lado, o intelectual e filosófico pelo outro, convergem para o delineamento de uma conceção do estado como poder absoluto de poucos e como opressão das livres individualidades dos súditos. Aqui teve origem esta "dureza da doutrina platônica do Estado, esta não natural e violenta repressão da autodeterminação individual, esta brutal renúncia à liberdade pessoal e política” (ibid.). O que em Hegel era limite de época do Zeitgeist grego, torna- 
se, com o 'liberalizante' Zeller, um aspecto inaceitavelmente peculiar do pensamento platônico. Tal como Platão tivera necessidade do Demiurgo para submeter com a força (aqui Zeller esquece significativamente o papel da "persuasão" no Timeu) a matéria à ideia, assim na política ele "tem necessidade do poder absoluto para domar o egoísmo dos indivíduos. Esta política não pode confiar no espírito comum que nasce do livre movimento dos indivíduos" (p. 646).

A propósito dos grupos funcionais da polis platônica, Zeller fala uma vez de "separação em castas" (p. 625), como faria Marx, mas pensa sobretudo nas três ordens medievais dos oratores, bellatores e laboratores. O paralelismo instituído por Zeller entre o modelo platônico e a Igreja medieval é iluminador. $\mathrm{O}$ historiador não recorre a ele para atribuir à cidade platônica um caráter "cenobítico", como muitas vezes se tem interpretado, mas antes para realçar o domínio social exercido por uma classe sacerdotal que recusa com os "votos" os objetivos individuais, e legitima o governo sobre a comunidade em nome de um saber transcendente que a ela apenas é acessível (p. 646). Mas esta caracterização sombria do projeto platônico como opressão violenta e não liberal não é a última palavra de Zeller sobre o Platão político.

Há, por último, uma abertura para um Platão visionário e profético, bem distante do intérprete fiel hegeliano do "espírito do seu tempo", melhor ainda, precursor anacrônico de um distante futuro. Sobre isto Zeller gasta palavras verdadeiramente belas que merecem ser transcritas: 
Platão quer efetuar no solo grego e de forma grega o que estava destinado a realizar-se noutra situação e sob outras premissas, porque ele antecipou audaciosamente as aspirações e as instituições do futuro. Podemos dizer que o seu erro não consistiu em ter proposto objetivos irreais com arbítrio fantástico, mas em ter tentado resolver prematuramente - por essa razão, com meios impossíveis - as tarefas postas pela história, de que ele tomou consciência com olhar profético (pp. 650 seg.).

Convém dizer, infelizmente, que os conteúdos atribuídos por Zeller a este olhar profético parecem um pouco decepcionantes. Há, sim, a precursão da paridade de direitos reconhecida às mulheres. Mas há, sobretudo, a abertura de uma via que levará em época moderna à instituição de uma "classe de funcionários", uma burocracia dotada de preparação científica, que juntamente com uma "classe de professores" tomará o lugar dos velhos filósofos-reis e, também, dos exércitos permanentes; a eles associa-se a classe dos produtores, que Zeller chama também «Terceiro Estado». A modernidade preconizada por Platão parece assumir, então, um aspecto decididamente prussiano-guilhermino, e acerca disto, como veremos, a discussão estava inevitavelmente destinada a reavivar-se. Todavia, é hora de assinalar que, depois de Zeller, não só Gomperz mas também, um século mais tarde, um filósofo hegeliano e liberal como Hans Georg Gadamer teriam voltado a reconhecer na proposta platônica de governo dos filóso- 
fos "a instituição da moderna condição profissional do empregado e o ideal da sua incorruptibilidade". Um Platão profeta da burocracia moderna representa, pelo menos, um modesto êxito exegético.

Ainda uma palavra sobre o tratamento zelleriano dos outros textos políticos de Platão. O Político é considerado cronologicamente anterior à República e é usado para realçar o caráter absolutista desta. Quanto às Leis, Zeller considerava-as inicialmente não autênticas, porque, ao contrário do organicismo da República, elas previam uma agregação de indivíduos mantidos juntos por obra de instituiçôes; em seguida, tê-las-ia considerado uma obra tardia e incompleta, dedicando-lhes consequentemente uma atenção bastante limitada.

Completamente diferente do clima zelleriano é a atmosfera do liberalismo, com veios socialistas, no qual se inscreve o grande historiador escocês George Grote (o seu Plato, and the Other Companions of Sokrates é de 1865; a terceira edição em quatro volumes é de 1888). Grote fora discípulo de James Mill, o pai de John Stuart Mill, e permanecera ligado ao seu empirismo filosófico e ao radical movement promovido por eles. As suas equilibradas páginas sobre a República constituem um notável exemplo de independência intelectual e de lucidez de juízo num ambiente, como o da cultura inglesa do século XIX, em que Platão não encontrara grande fortuna.

As críticas de Grote concentram-se nos aspectos educativos e propriamente políticos do modelo platônico. Na República, Platão descreveu só "o cérebro e o coração do grande Leviată”, isto é, a educação e a 
forma de vida das classes dirigentes: "filosófica" e militar. Repreensivelmente, Platão negligenciou de todo a discussão dos modos de educação popular, pois à terceira classe não parece sobrar senão uma "ilimitada submissão às ordens dos governantes sustentados pela força dos guardiōes" (pp. 139 seg.). A ausência de um programa educativo da classe dos produtores, e o vínculo que os obriga a exercer um só tipo de trabalho, faz deles "mais máquinas que indivíduos humanos" (pp. 186 seg.).

Acerca do plano político, o sistema da República mostra-se contrário ao livre pensamento, às free-thinking minds. O Sócrates histórico, com a sua dialética negativa tão apreciada pelos Mill, não poderia existir na cidade platônica, que prevê uma "autoridade infalível, temporal e espiritual”: na República, Sócrates transformar-se-ia, assim, numa espécie de Dictator (pp. 211 seg.).

De modo bastante surpreendente, em relação a toda a tradição crítica, o "radical" Grote está, ao invés, disposto a encontrar motivos de consenso para a estrutura social da comunidade platônica (que, notese, ele chama sempre Commonwealth, em significativa oposição ao Staat dos autores alemães). O "comunismo" platônico (que, nota Grote, ao contrário do comunismo moderno, não é um comunismo dos produtores) é, de fato, apenas parcial, limitando-se ao grupo dos guardiōes. Mas, segundo Grote, tratase para Platão só de um second best: mesmo achando auspiciosa uma comunhão universal, ele não teria ousado ir tão longe. 
Posto isto, o argumento forte que impele Platão à abolição da propriedade privada e da família para os governantes consiste no apelo à sua dedicação absoluta à comunidade (p. 169 segs.). Segundo Grote, Platão tem razão (contra Aristóteles e Xenofonte) em considerar os interesses privados e as tarefas públicas inconciliáveis (o conflito de interesses pode ser mitigado, mas não superado, pela avaliação popular da obra dos governantes). O objetivo razoável de Platão consiste portanto na "completa extinção" da figura "of the old individual Adam - of all private feelings and interests" (pp. 183 seg.). Nada de absurdo nem mesmo na proibição dos casamentos: pelas mesmas razões (evitar o conflito entre interesses privados e missão pública) a Igreja Católica impôs aos seus sacerdotes o celibato (aliás, Platão é mais indulgente, porque não proíbe as relações sexuais, mas só a estabilização dos vínculos matrimoniais) (p. 193).

Há mais. Em relação a Xenofonte e a Aristóteles, o modelo platônico propõe "uma conceção mais ampla e mais generosa do objetivo das instituições políticas», porque pede que os guardiōes governem também no interesse da massa popular dos produtores, que Aristóteles ao invés tende a excluir dos direitos de cidadania (pp. 183 seg.).

Nos seus conteúdos sociais, a kallipolis da República parece em parte aceitável a Grote, e sê-lo-ia provavelmente na sua totalidade se fosse associada a um adequado programa de educação popular e se concedesse mais espaço à liberdade de pensamento e ao direito de crítica. 
Todavia, segundo o historiador escocês, a sua realização é impossível. Não porém pelas razões apresentadas por Aristóteles. Ele dá voz apenas a enraizados preconceitos acerca da família e da propriedade privada, de maneira que "a suposta impossibilidade é só o modo de exprimir desaprovação e repugnância” (p. 191).

A verdadeira razão desta impossibilidade é outra. O projeto platônico esbarra no fato que todas as comunidades humanas existem com costumes diferentes dos que ele propõe (estamos portanto muito longe da correspondência com o Zeitgeist hegeliano). E, pergunta-se Grote, de onde vem a força necessária para desenraizar os velhos costumes e gerar os novos, para lhes dar o first start? É apenas um "pio desejo" (uma forma daquela euché que Platão deplora), a esperança formulada no livro VI da República que esta demiurgic force possa vir de um déspota convertido à filosofia (fiel ao seu princípio salutar de autonomia de cada diálogo, Grote não se refere aqui à passagem do livro IV das Leis, 709e segs., onde se espera que esta "força" possa provir da de um "bom tirano" disposto a colaborar com o legislador filósofo). É pois essencialmente um problema de força o que, segundo Grote (no meu parecer, aqui ele está muito perto do estilo do pensamento platônico), impede a possibilidade de realização do projeto. E não obstante, conclui o historiador de modo absolutamente original, se alguma vez ele fosse aviado, poderia funcionar (pp. 190 seg.).

Permanecemos no ambiente dos Mill com o grande filólogo vienense Theodor Gomperz, que traduziu para o alemão as obras de John Stuart e que parece, já 
em 1858, ter encontrado nelas o impulso para escrever uma história da filosofia antiga "from the point of view of the Experience philosophy": um impulso que produziu, a partir de 1896, a monumental obra dos Pensadores gregos. Apesar das simpatias de Gomperz - sensível também à influência do positivismo de Comte - se dirigirem naturalmente para Aristóteles, o III volume da obra é inteiramente dedicado a Platão, do qual se faz um retrato não privado de respeito e por vezes até de admiração.

No campo político, Gomperz não pode senão apreciar a intenção central de Platão: a de levar ao poder "a inteligência alimentada de ciência", uma intenção que requer como condições próprias a abolição da propriedade privada, a supressão da família e, com ela, a emancipação das mulheres (um projeto para o qual o progressista Gomperz exprime a sua "admiração") (pp. 432 seg.). Este conjunto de condições teria feito com que Platão fosse induzido a privilegiar os conteúdos político-sociais do seu projeto em relação aos éticos (p. 403): uma posição exegética exatamente oposta, como veremos, à de muitos intérpretes de finais do século XX.

Pode parecer surpreendente (mas no fundo não demasiado distante da problemática de Grote) o modo como Gomperz estrutura a sua avaliação crítica da política platônica. Platão não duvidara da bondade e da utilidade do seu projeto, mas das suas possibilidades de realização. Ora, observa o historiador vienense, "a consideração de realizações efetivas de que não faltam inteiramente exemplos, e o confronto desapaixonado 
de tal regime com o regime tradicional, permitemnos, creio, inverter até a sua posição" (p. 358). A esta aproximação geral, Gomperz une a sua resposta a uma "pergunta recorrente": Platão pode ser considerado "precursor dos modernos socialistas e comunistas"? A pergunta não era assim tão óbvia: a torná-la "recorrente» contribuiu provavelmente a publicação do livro de Pöhlmann, intitulado Geschichte des antiken Sozialismus und Kommunismus na I edição de 1893, que todavia Gomperz não cita, além, de modo geral, do impetuoso desenvolvimento da social-democracia alemã de finais do século XIX.

Para começar com esta pergunta, a resposta de Gomperz é, razoavelmente, "sim e não". Sim, porque Platão, da República às Leis, "ficou irremediavelmente parado no ideal comunista", convicto (com "saudável bom senso") de que para pôr o poder absoluto da inteligência ao abrigo da tentação de abuso, explorando os súditos, não bastava a educação mas ocorria garanti-la com a ausência de todos os interesses privados (p. 408): aqui Gomperz concorda com Grote contra Aristóteles. Não, porque, ao contrário do comunismo moderno, o projeto platônico não prevê a "socialização dos meios de produção" (p. 430) e está limitado, sobretudo, ao grupo dirigente da nova sociedade, excluindo as massas populares: uma atitude de desprezo devida ao espírito aristocrático de Platão, sustenta Gomperz seguindo Zeller, às suas simpatias filoespartanas e, talvez, à memória das comunidades pitagóricas. Aos trabalhadores não cabe, portanto, a submissão ao domínio da elite da inteligência, embora 
segundo Platão esse constitua uma forma de "tutela salutar para as massas” (p. 404).

Mas voltemos à inversão da perspectiva platônica operada por Gomperz. Ela não parece de todo impossível. O argumento de Aristóteles, segundo o qual se fosse possível já teria sido realizada, é "sempre repetido por todos os espíritos conservadores contra as inovações mais radicalmente subversivas", mas não se sustenta perante um visual histórico e etnográfico mais amplo (p. 425): o que sai do normal não é por si só impossível. Com efeito, experimentos semelhantes foram realizados na Idade Média por comunidades religiosas e pela ordem dos cavaleiros teutônicos, um grupo guerreiro alimentado por populações camponesas protegidas e tributárias. E existem na América hodierna, acrescenta Gomperz, seitas como a dos Perfeccionistas que praticam o "comunismo matrimonial" (p. 431). Gomperz considera-se capaz de dar resposta positiva até mesmo a uma ulterior pergunta: assim que for realizado, o modelo platônico perdurará? Sim, se se pensar, por exemplo, no "despotismo teocrático do Império dos Incas” (p. 427).

Estas referências históricas (para dizer a verdade, um pouco heterogêneas e bizarras) garantem que o comunismo de matriz platônico não é irrealizável. Diferente, e mais esfumado, é o juízo sobre a sua desiderabilidade.

Também aqui Gomperz está disposto a reconhecer as boas razóes de Platão. Ele desejava garantir a potência ilimitada da inteligência, libertando-a da "obtusa resistência da estupidez": algumas das medidas extremas previstas pelo filósofo, como o exílio da 
poesia, lembram a Gomperz prescrições semelhantes apresentadas por Comte, como a destruição dos maus livros (pp. 428 seg.). Mas, em geral, é o que pertence à individualidade, com a sua tendência incoercível à anarquia, a constituir um impedimento à plena realização do ideal. Daqui chega a Platão a tendência a negar qualquer autonomia ao indivíduo e a preconizar, escreve Gomperz, "uma uniformidade universal de tipo chinês" (curiosamente, em Gomperz soa um juízo de Athanasius Kircher que, em 1667, aproximara a República platônica à China e os filósofos-reis aos seus mandarins). Mas não se trata absolutamente do "espírito do tempo" hegeliano: a consciência liberal do século XIX (aqui são indicados os nomes de Tocqueville e Stuart Mill) contrapôs Platão "ao ideal de Péricles", com o seu livre desenvolvimento da individualidade no contexto da polis (pp. 409 segs.). Como veremos, esta contraposição estava destinada a ter uma longa fortuna, chegando a Popper e indo além dele.

Igualmente reprovável, aos olhos desta consciência, é a aversão de Platão ao progresso: no seu estado ideal não se poderia compor um texto inovador como a República e até mesmo as Leis teriam sido sem dúvida censuradas pelos guardiōes da kallipolis. O risco que Platão corre é o de uma "esclerose espiritual" da comunidade, com a instauração de uma espécie de "pedantocracia" (o termo é atribuído a Mill e a Comte): e isto em estridente contraste com a incansável evolução do pensamento crítico do mesmo Platão (p. 428). Deste ponto de vista, Aristóteles não estava completamente errado: o projeto platônico acaba por empobrecer e mutilar a natureza 
humana (p. 430), com a sua preciosa variedade de inclinaçóes e sentimentos, com as suas aspiraçóes ao progresso e à liberdade.

Quanto ao controle demográfico e às ações eugênicas previstas na República, encontradas na história grega e, em particular, espartana, Gomperz garante com um toque de otimismo que - à beira do século XX - soa quase comovente: "a nossa época nunca pensará num regresso às açôes cruéis dos legisladores gregos" (p. 421). Sabemos, infelizmente, que se iria muito além dessas ações e, como veremos, que Platão seria saudado como guia.

Pelo contrário, Gomperz vê em Platão o precursor de novidades bem mais positivas, que identifica, de maneira bastante semelhante a Zeller, à moderna instituição de uma classe de "funcionários com instrução especial”, de exércitos permanentes, da divisão social do trabalho, além, naturalmente, da emancipação feminina. Mas, sobretudo, para o progressista Gomperz o "mérito imortal" de Platão consiste, sobretudo, em ter pesquisado as instituições humanas com "o olhar da razão numa investigação livre”, para abrir uma via iluminista no "triplo muro da tradição, preconceito e abuso da força” (pp. 437 seg.). Este mérito é confirmado pelas Leis, segundo as quais, no parecer de Gomperz, falta aquela "dureza do sentir", aquele "exaltado idealismo" que marcaram a República sem, todavia, renunciar àquilo que de socialmente positivo ela propusera.

Grote, por um lado, Gomperz, por outro, oferecem-nos, pois, um Platão político interpretado com simpatia pelas suas razões e avaliado com um certo 
equilíbrio em claro-escuro, e sem gestos de execração, do ponto de vista do liberalismo progressista do século XIX. Um passo mais decisivo seria dado, em finais do século XIX, por historiadores e pensadores orientados para o socialismo e atentos ao pensamento de Marx.

\section{Platão "socialista": Pöhlmann e Natorp}

Os capítulos da grande obra histórica de Robert von Pöhlmann dedicados a Platão oferecem indubitavelmente uma das discussões mais fortes e interessantes acerca do pensamento político do filósofo. $\mathrm{O}$ fato que esta análise não tenha desempenhado um papel muito significativo na história da interpretação deste filósofo, deve-se provavelmente a uma pluralidade de razões. A primeira razão é a sua pertença a uma obra com um título muito genérico (Geschichte des antiken Sozialismus und Kommunismus, na primeira edição de 1893, Geschichte der Sozialen Frage und des Sozialismus in der antiken Welt, na segunda edição de 1912) e com conteúdos indiscutivelmente anacrônicos, como a tese da difusa presença do capitalismo, da grande indústria e da luta de classes na sociedade antiga; a segunda consiste na secundariedade do autor (1852-1914), que foi o primeiro historiador do Renascimento e, depois, da antiguidade clássica (em Munique); a terceira, e principal, consiste na anomalia da sua posição geral. Moderadamente progressista, Pöhlmann era hostil quer à "democracia radical” (que identificava em Mill e Grote), considerada incapaz de superar os egoísmos de classe e a "plutocra- 
cia" inglesa (pp. 124, 129), quer ao marxismo e, sobretudo, aos ideólogos da social-democracia, como Bebel e Kautski, aos quais atribuía ilusões "mais infantis que platônicas" do advento próximo de uma idade de ouro, da palingênese pós-revolucionária do gênero humano (pp. 159 seg.). A atmosfera cultural do Terceiro humanismo, após a crise que seguiu a Primeira Guerra Mundial, teria tornado decididamente a posição não atual, típica de finais do século XIX, do "socialista" mas realista Pöhlmann, cujas simpatias se dirigiam sobretudo a Fichte e a Bentham.

A sua ampla análise do Platão político segue uma estratégia dupla. Por um lado, ele defende com força a coerência lógica, a potência intelectual "cheia de futuro" do desenho platônico (p. 134) da sequela das críticas que tradicionalmente lhe foram formuladas (a República é definida, kantianamente, "Estado de razão", Vernunftstaat, em contraposição ao "Estado da lei", ou das Leis); por outro lado, põe em evidência as ilusóes antropológicas, a fragilidade "iluminista" em relação às efetivas possibilidades de realização histórica.

A defesa de Pöhlmann da República frente aos seus críticos antigos e modernos está articulada em vários aspectos.

O primeiro tema crítico é o do poder absoluto concedido à elite de governo. Trata-se, segundo Pöhlmann, de uma medida consequente à exigência de emancipar a dimensão política e estatal do domínio dos interesses econômicos das classes sociais contrapostas e do controle de maiorias incompetentes. A abolição do caráter privado na vida da classe dirigente é necessária 
para subordinar o egoísmo individual às finalidades coletivas do estado que deve ser guiado por homens possuidores dos mais altos conhecimentos científicos. Nisto não há nenhum preconceito aristocrático, como haviam dito Zeller e Gomperz, nem nenhum desprezo das massas à maneira de Nietzsche, mas um conjunto de consequências que derivam logicamente de premissas consideradas desejáveis (unidade, justiça, bom governo da comunidade política) (pp. 10 segs., 49, 80). É interessante a justificação oferecida por Pöhlmann para o controle estatal da reprodução do grupo dirigente com o fim de evitar a sua decadência: nada de estranho, afirma, no cenário da política matrimonial habitual nas grandes famílias gregas e da difusa conceção da geração de filhos como serviço oferecido à polis (p. 23).

Mais ampla é a resposta formulada por Pöhlmann a uma longa tradição crítica, que vai de Aristóteles até Gomperz, segundo a qual Platão teria negligenciado completamente a questão da classe dos produtores e dos comerciantes, o "Terceiro Estado" da República. É igualmente verdadeiro que Platão se recusa a delinear uma legislação no terreno econômico, salvo os princípios gerais de controle público sobre a economia que consistem em prescrever a especialização dos deveres produtivos e em evitar os excessos de riqueza e pobreza (livro IV) e de dívida (livro VIII). Com efeito, quer a República (425c segs.) quer o Político consideram este âmbito demasiado mutável e complexo para poder tornar-se objeto de uma legislação constitucional, e deixam-no ao controle das devidas magistraturas. 
Ao contrário, Platão ocupa-se seriamente da condição moral e educativa da classe dos produtores. De resto, seria absurdo, observa Pöhlmann, "pôr a pequena comunidade de guardióes, organizada de modo puramente socialista e centralizado, ao centro de uma sociedade cuja vida inteira seria governada pelo princípio diametralmente oposto do Laissez-faire" (pp. 28 seg.). Não há preconceitos classistas em Platão: o trabalho manual não impede a moralidade, a "virtude demótica e política" de que fala o Fédon, se é verdade que também para a terceira classe se requer o acesso às virtudes coletivas da moderação (sophrosyne) e da justiça (pp. 36-9). Esta forma de moralidade difundida é, de resto, implícita na intenção platônica, reafirmada continuamente nos livros IV e V da República, pois a nova formação social deve ser realizada com vista à felicidade não só do grupo dirigente, mas de todo o povo. De fato, trata-se, insiste Platão, de uma comunidade de cidadãos "irmãos" (414e), "aliados", "livres e amigos" (547c), unidos entre si por uma fortíssima solidariedade coletiva (pp. 50 segs., 60 seg.).

Tudo isto implica inevitavelmente um forte engajamento na educação social, de soziale Pädagogik, como diz Pöhlmann, concordando, como veremos, com o neokantiano Natorp. Dado que o sistema platônico não é de castas e prevê a mobilidade entre grupos sociais, ele implica, em primeiro lugar, uma extensiva educação de todos os jovens, dentre os quais se selecionariam os melhores (p. 54): a eles se destina aquela poesia emendada em sentido educativo, segundo as indicaçôes que Platão dá nos livros II e III da 
República. Mas a intenção educativa de tornar todos os cidadãos, moralmente "melhores", é central na política platônica, do Górgias ao próprio Político (297b). $\mathrm{Na}$ República, é decisiva a possibilidade de tornar a terceira classe partícipe daquela sophrosyne que garante o consenso à distribuição desigual das funções de governo sem recorrer a uma "repressão policial da massa”. A isso se destinavam a educação musical e poética, além das artes figurativas, e o positivo influxo moral que um ambiente social harmonioso exerce na totalidade da população (Resp. III 401a segs.) (pp. 55 segs.).

De resto, Pöhlmann não tem dúvidas de que Platão "auspiciou a maior extensão possível de comunismo" também para a classe dos produtores, como se vê nas passagens do livro $\mathrm{V}$ da República que insistem no ideal da unidade social capaz de envolver "todos os cidadãos" (462b) e na nova evocação do ideal comunista do livro $\mathrm{V}$ das Leis, onde se auspicia que ela seja "o mais possível" (hoti malista, Leg. 739c-d) extensiva (pp. 74-9). Em todo o caso, na cidade platônica as massas não estariam ao serviço da aristocracia, mas seria a elite no poder que estaria ao serviço da comunidade: Platão antecipa, assim, o princípio de Bentham da "máxima felicidade possível para o maior número possível”, mas vai além deste princípio na direção de um comunismo cuja plena realização é provavelmente impossível, mas que deve ser igualmente estendido em potência a todo o corpo social (p. 83).

Contestado assim o primeiro núcleo de críticas ao desenho platônico, Pöhlmann enfrenta o segundo que nasce com Hegel e continua com Zeller: de fato, a sua é 
a primeira refutação do axioma, em aparência inatacável, segundo o qual Platão, coerente ou não ao "espírito do tempo", teria sacrificado inteiramente o princípio da subjetividade individual em favor do organicismo comunitário e estatal. Mas trata-se de um erro de cálculo que confunde organicismo estatal com uma exigência que é, na realidade, de solidariedade social. É verdade que os órgãos políticos devem dispor de força suficiente para subordinar os interesses particulares aos coletivos, com a intenção de harmonizar uns e outros. Mas é igualmente claro, pelo livro IV da República, que a felicidade pública terá consequências inevitáveis na felicidade dos indivíduos, enquanto que, pelo contrário, é impensável uma felicidade privada num contexto coletivo governado pela injustiça. A justiça, virtude comunitária por excelência, significa também saúde e bem-estar para a alma de cada indivíduo ( 444 d segs.). Pöhlmann chega assim a definir o projeto político platónico como um "socialismo individualista”, ao qual se une, também, "o utopismo socialista mais moderno que imagina a organização social com base em associações de trabalhadores" (pp. 111-2).

Por último, a questão da possibilidade de realização deste projeto de "socialismo". Platão tem perfeitamente consciência da distância entre teoria e práxis e, por conseguinte, da impossibilidade de uma perfeita adequação entre realidade e plano ideal, do qual se pretende aproximar o mais possível (engytata, 473a). Mas, insiste Pöhlmann, Platão exclui que se trate apenas de fromme Wünsche, "pios desejos". A possibilidade de realização histórica do projeto, por mais imperfeita 
que seja, é garantida grosso modo pela sua correspondência com as máximas quer da "natureza" quer da razão. Certamente ocorre, para abrir-lhe o caminho, uma "educação social de massa", a propósito da qual se considera de novo a tese de Fichte (pp. 114 seg.). E a reeducação moral dos cidadãos requer, por sua vez, que a elite dirigente disponha de uma "autoridade absoluta”; Pöhlmann abre de maneira significativa a sua discussão das Leis, citando uma passagem do livro IV (709d segs.) que detecta na colaboração entre um bom legislador e o poder absoluto do tirano "a via mais rápida e eficaz” para a transformação moral e política da sociedade. Exprimem-se aqui as esperanças suscitadas no século IV pelo desenvolvimento das monarquias absolutas. Neste sentido, e apesar das críticas à tirania no livro IX da República, Platão se apresenta como um "partidário do cesarismo", como de resto foram, segundo Pöhlmann, os grandes reformadores sociais de Rousseau a Saint-Simon e Lassalle.

Um Platão, portanto, "cheio de futuro", como atestam as suas ideias sobre a democratização antiplutocrática da economia política, ou sobre a emancipação feminina (apesar de ela subestimar a potência do instinto maternal) (pp. 129-34).

Mas Pöhlmann não conclui a sua análise com esta defesa de Platão dos seus críticos tradicionais e com estas apreciações positivas. Há, em Platão, preconceitos, erros e ilusões. Por mais que ele tenha justamente posto "a harmoniosa composição entre ideia de liberdade e necessidade da constrição estatal como objetivo de toda a política quando desenha o ideal de uma 
forma de governo que prevê a espontânea submissão dos súditos", depois errou ao identificar os meios para alcançar esse objetivo (p. 143).

Os erros de Platão podem ser resumidos num erro capital: o de ter supervalorizado a eficácia da política e da educação em relação à 'viscosidade' antropológica da natureza humana. A criação de uma aristocracia do espírito, "a criação de gênios”, a consolidação da classe dirigente mediante o saber e a educação, não são senão "sonhos" ou "fantasmas" (phantom) (p. 138 seg.). Platão supervaloriza, de forma iluminista, a valência ética do saber, a eficácia psicológica das instituições sociais, o poder transformador da educação. Antecipando "o otimismo educativo socialista" dos social-democratas modernos como Bebel, Platão cultiva, assim, a ilusão de que o comunismo possa desenraizar os desejos individuais, o egoísmo pessoal e de classe. Pode-se notar que aqui, talvez, o crítico não seja justo com Platão que, no início do livro VIII da República, atribuía a crise da cidade justa, uma vez realizada, exatamente ao incoercível regresso destes egoísmos para o interior do grupo dirigente - mas que pensava, apesar disso, que se tratava de batalha digna de ser travada, mesmo se o eventual sucesso não fosse irreversível.

Em todo o caso, Pöhlmann defende que a natureza humana não é capaz de reger a fusão social, a fraternidade, a harmonização dos interesses públicos e privados. Portanto, escreve ele com palavras que de algum modo soam proféticas, "o Estado da perfeita justiça, da verdadeira liberdade e igualdade" - tão semelhante ao "Estado futuro do marxismo" - assim que for re- 
alizado, arrisca-se a ver as boas intençōes viradas do avesso: constrição e coerção em vez de liberdade, "máquina” do Estado em vez de organismo solidário (p. 151). A crítica não deve, portanto, ser dirigida ao sentido do projeto platônico, mas aos meios usados para a sua realização, ao mau uso corre o risco de produzir uma caricatura deformadora do projeto.

Em vez de cultivar esperanças milenaristas acerca do advento da Idade do Ouro, ou de confiar em uma aristocracia de semideuses deixando o povo privado de expressão política, convém confiar, segundo Pöhlmann, no desenvolvimento da civilização que do despotismo oriental, gradualmente alcançou o sufrágio universal. Por esta via, o socialismo de Pöhlmann efetua a sua reviravolta, que consiste num regresso a Kant, anterior a Hegel e à sua tradição. O estado ideal de Platão deve ser concebido como ideia transcendental que não pode encontrar uma sólida realização na história (de fato, seria, como no caso "marxista", o último estado, sem ulteriores possibilidades de progresso). Mas ele deve ser perseguido precisamente como ideal limite, ao qual é preciso aproximar-se progressivamente, e a "potência intelectual" de Platão consiste na conceção deste ideal (pp. 159 segs.). Mas Pöhlmann dá um passo decisivo em relação a Kant: se ele não conseguiu justificar, do ponto de vista dos conteúdos, as razōes pelas quais o desenho platônico devia ser aceite como ideal da práxis histórica, é precisamente nestes conteúdos que o "socialismo" do nosso autor reconhece a validade e a "plenitude de futuro".

Podemos fazer apenas uma menção ao amplo tratamento que Pöhlmann (também devido a este aspecto 
inovador relativamente à tradição exegética) dedica ao "Estado das Leis". Nele, Platão faria, realisticamente, maiores concessões à fraqueza e ao egoísmo da natureza humana, renunciando, por isso, ao sistema de poder absoluto e ao comunismo da República. A ideia de estado fechado e de moralização da economia política, além da completa intenção sozialreformatorich, fariam todavia de Platão, nas Leis mais que na República, um direto precursor de Fichte (p. 242).

Diversamente de Pöhlmann, Paul Natorp - expoente de realce da escola neokantiana de Marburgo - desempenhou um papel importante na história das interpretaçōes de Platão, de quem apresentou uma imagem sobretudo inspirada em Kant, na obra Platos Ideenlehre, editada em 1903; também no plano político, o "socialismo ético" de Natorp (rebatizado ironicamente "socialismo da cátedra”), e dos outros neokantianos como Cohen gozou, de uma certa influência no debate no seio da social-democracia alemã anterior à guerra de 1914.

No seu breve mas importante ensaio de 1895, Plato's Staat und die Idee der Sozialpädagogik, Natorp parte do ponto de chegada de Pöhlmann. A ideia platônica de estado deve ser concebida como um ideal em sentido kantiano: decerto não situado no mundo hiperurânio, mas um modelo de perfeição da comunidade social que nunca poderá ser inteiramente transferido para a realidade, mas que é capaz de orientar a vontade na direção de um progresso ilimitado (pp. 10 seg.). Entendido deste modo, o projeto político de Platão deixa de ser compreendido como utopia à ma- 
neira de Thomas More, mas, precisamente, como um ideal valorizador e regulador da práxis. De resto, Platão parte de um fundamento "realístico" (a análise da comunidade econômica e da sociedade do luxo no livro II da República), e igualmente realística é a sua intenção reformadora (p.17). Natorp detecta duas fases no pensamento político de Platão: a primeira, expressa sobretudo no Górgias, de natureza "negativo-crítica", a segunda, que se afirma na República, de natureza "positivo-revolucionária" (p. 14).

Os conteúdos principais da proposta revolucionária de Platão são dois. O primeiro consiste na conceção "social-pedagógica" do estado. A sua tarefa deve ser a de superar o egoísmo dos interesses individualistas, a desigualdade social, a contraposição violenta das classes, através do trabalho de construção social inspirado numa "ideia moral de sociedade" que se obtém precisamente com um esforço de educação coletiva, de formação moral dos cidadãos. Estado, sociedade e educação formam em Platão um laço indissolúvel, que mantém ainda na modernidade todo o seu valor projetivo (pp. 5 segs., 21).

O segundo conteúdo do ideal platônico é constituído pelo comunismo. Em parcial desacordo com Pöhlmann, Natorp reconhece a limitação da forma de vida comunista apenas ao grupo dirigente, que não chega a fundar uma nova ordem econômica. É verdade que uma passagem das Leis (V 739 b segs.) parece preconizar uma extensão universal desta forma de vida. De fato, escreve Natorp, "Platão reconheceu o autêntico comunismo econômico como a verdadeira 
consequência das suas premissas" (nota 24, p. 31), mas rejeitou-o, circunscrevendo o comunismo à aristocracia dirigente, sem uma efetiva emancipação dos trabalhadores, porque ela lhe parecia, no seu tempo, a única possibilidade realisticamente praticável (pp. 236), como já havia suposto Grote. Deste modo, Platão teria reaberto uma frecha na comunidade social, restringindo o pleno acesso à razão à classe dominante, e deixando à classe dos produtores apenas a esfera dos desejos e o pedido de uma passiva submissão.

Apesar deste limite, é indubitável, segundo Natorp, que o comunismo de More derive do de Platão, e que ambos estejam na origem do socialismo moderno (p. 6). Até o princípio da "propriedade coletiva dos meios de produção" e o coletivismo socialista derivam das premissas de Platão, mesmo contra a renúncia do próprio Platão em desenvolver coerentemente os seus pressupostos (p. 24). Projeta-se, hoje, de substituir a velha aristocracia por uma nova aristocracia espiritual com bases socialistas e democráticas, e nada impede que esta nova aristocracia vista "o avental de trabalho". "Se esta é utopia, conclui Natorp, então o socialismo hodierno é tão utopista como o platônico" (p. 26).

O filósofo de Marburgo crê portanto, mais do que acreditava Pöhlmann, nos ideais da social-democracia de finais do século XIX e, precisamente por isto, tem uma atitude mais crítica relativamente ao elitismo aristocrático de Platão; mas isso não lhe impede de reconhecer nele o mais poderoso inspirador daqueles ideais.

A última palavra do século XIX, após Hegel, parece entregar ao novo século uma imagem de Platão de- 
cisivamente caracterizada em sentido kantiano e socialista. Esta imagem não resistiria, contudo, por muito tempo: ela estava destinada a ser 'abalroada' pela crise do pós-guerra e pela simultânea reviravolta, classicista, neo-hegeliana e, por fim, reacionária, da filologia clássica alemã.

\section{NOTA BIBLIOGRÁFICA}

Sobre Brucker $c f$. M. LONGO, in G. SANTANELLO (a cura di), Storia delle storie generali della filosofia, Brescia: La Scuola, 1979, vol. II, pp. 527-635.

A Crítica da razão pura de Kant é citada a partir da edição de 1787; a tradução utilizada é de P. Chiodi, Torino: UTET 1967. Para os outros textos de Kant, cf. Scritti politici, tradução italiana de G. Solari e G. Vidari, Torino: UTET, 1955.

Em geral, sobre o Platão político no pensamento do idealismo alemão, $c f$. J.-L. VIEILLARD-BARON, Platon et l'idéalisme allemand, Paris: Beauchesne, 1979, pp. 351-69; M. ISNARDI PARENTE, La "Repubblica" di Platone in Germania nel secolo di Marx, in "Belfagor", 37 (1982), pp. 617-32.

Sobre a relação entre Kant e o Platão político, cf. M. D'ADDIO, Kant e la Repubblica platonica, in "Il Pensiero politico", 9 (1976), pp. 472-80; o livro de T. K. SEUNG, Kant's Platonic Revolution in Moral and Political Philosophy, Baltimore: Johns Hopkins University Press 1994, oferece menos do que o título prometera. 
Para as Liçôes de história da filosofia de Hegel, consultou-se a edição de, 1833 organizada por Michelet e confrontada com a edição crítica Garniron-Jaeschke, editada e traduzida por V. Cicero, Milano: Rusconi 1998; consultou-se também a versão Griesheim, traduzida em G. W. F. HEGEL, Lezioni su Platone (1825-1826), a cura di J.-L. Vieillard-Baron, tradução italiana de G. Orsi, Milano: Guerini, 1995. Para os Lineamentos de filosofia do direito usou-se o texto e a tradução de V. Cicero, Milano: Bompiani, 2006.

Sobre Hegel e Platão, $c f$., além das obras citadas, G. DUSO, Platone e l'eticità greca nella lettura hegeliana, in G. Movia (a cura di), Hegel e Platone, Cagliari: Ediz. AV 2002, pp. 30942; mais em geral, os ensaios contidos em Hegel et la pensée grecque, par J. D'Hondt, Paris: PUF, 1974.

Acerca de Platão entre Hegel e Marx, cf. G. FARINETTI, Il confronto di Marx con Platone (attraverso Hegel), in CR IV, 2000, pp. 497-559. O capital é citado com a tradução de D. Cantimori, Roma: Editori Riuniti, 1970.

A Filosofia dos Gregos no seu desenvolvimento histórico de E. ZELLER dedica ao pensamento político de Platão a secção XI da Segunda Parte, vol. III. Ela foi traduzida para italiano em E. ZELLER, R. MONDOLFO, parte II, vol. III/2, Firenze: la Nuova Italia, 1974, pp. 557-656 (que correspondem às pp. 892-925 da V edição do texto alemão). Esta edição contém as notas indispensáveis de atualização redigidas por M. Isnardi Parente ( $c f$. sobretudo as pp. 564-83, 604-24).

Sobre Zeller, $c f$. G. CAMBIANO, Stato greco e filosofia in Eduard Zeller, in "Annali della Scuola Normale Superiore di Pisa”, Classe Lettere e Filosofia, série III, XIX, 3 (1989), pp. 1117-42. 
As citaçôes de G. GROTE foram retiradas do IV, volume de Plato, and the Other Companions of Sokrates, London: Aberdeen University Press, 18883. Acerca de Grote e do seu ambiente, $c f$. J. GLUCKER, Plato in England. The Nineteenth Century and After, in H. Funke (Hrsg.), Utopie und Tradition. Platons Lehre in der Moderne, Würzburg: KönigshausenNeumann, 1987, pp. 149-209; G. GIORGINI, Radical Plato. John Stuart Mill, George Grote and the Revival of Plato in XIXth Century England, in "History of Political Thought", no prelo, e os ensaios contidos em George Grote Reconsidered, edited by W. M. Calder III, S. Trzaskoma, Hildesheim: Weimann, 1996.

A obra de T. GOMPERZ, Pensadores gregos, é citada a partir da tradução italiana do III volume, Firenze: la Nuova Italia, 19532. Sobre Gomperz, cf. S. TIMPANARO, Theodor Gomperz, in "Critica storica", II (1963), pp. 1-31; a correspondência com Stuart Mill é publicada em F. HEINIMANN, Theodor Gomperz und John Stuart Mill, in "Philosophia", 1-4 (1938), pp. 188-94.

A obra de R. VON PÖHLMANN é citada a partir do II volume da III edição (póstuma), München: Beck’sche Verlagsbuchhandlung 1925 (em substância, idêntica às anteriores, salvo o título e um apêndice crítico organizado por F. Oertel).

As citações de Natorp foram retiradas de P. NATORP, Plato's Staat und die Idee der Sozial-pädagogik, Berlin: Carl Heimanns Verlag, 1895. Sobre Natorp e a interpretação neokantiana de Platão, cf. em geral K.-H. LEMBECK, Platon in Marburg, Würzburg: Königshausen-Neumann, 1994; acerca dos aspetos políticos, $c f$. a antologia de H. J. SANDKÜHLER, R. DE LA VEGA (Hrsg.), Marxismus und Ethik. Texten zum neukantianischen Sozialismus, Frankfurt: Suhrkamp, 1970 (tradução italiana Marxismo ed etica, a cura di E. Agazzi, Milano: Feltrinelli, 1975). 
4.

\title{
DO TERCEIRO HUMANISMO AO PLATÃO "NAZI"
}

\author{
"SOB A BANDEIRA DE PLATÃO": \\ WILAMOWITZ, JAEGER, STENZEL
}

Doucas décadas separam o sereno ambiente cultural bria atmosfera presente na Alemanha dos anos vinte, saída da derrota no conflito mundial e do trauma da revolução republicana. É nesta atmosfera que se dá o "regresso" ao Platão político - fecundo em efeitos futuros -, primeiro, por obra de Ulrich von Wilamowitz, prestigiado professor catedrático de filologia clássica na Universidade de Berlim, depois por obra do Terceiro humanismo (isto é, terceiro depois do Renascimento e da época de Goethe) de Werner Jaeger (que foi o sucessor de Wilamowitz em Berlim) e de Julius Stenzel.

Os temas que motivam e orientam este regresso podem ser resumidos em poucas táticas teóricas. A primei- 
ra consiste na reativação da tese hegeliana, segundo a qual Platão havia expressado o "espírito do tempo", dando forma ideal ao estado grego e à sua "ética substancial”. A segunda tática é, pelo contrário, anti-hegeliana: a fidelidade de Platão ao espírito do seu tempo não representa de maneira nenhuma o limite histórico, destinado a ser superado dialeticamente por outras formas superiores espirituais; o mundo grego e a sua idealização platônica constituem uma "forma eterna" (as palavras são de Jaeger e encontram-se presentes em Paideia, I, p. 5) insuperável e até ao momento exemplar. Exemplar sobretudo para a Alemanha, que com os gregos - e aqui se esboça a terceira e decisiva tática - mantém uma profunda afinidade espiritual. Esta afinidade pode, de certa forma, parecer previsível, com base na primazia europeia da filologia clássica alemã entre os séculos XIX e XX, mas é justificada arriscada e ulteriormente. De fato, na mesma página de Paideia, Jaeger fala de "afinidade espiritual marcada pelo destino, ainda vivo e ativo em nós". Se no discurso de Basileia de 1914 Jaeger havia atribuído à filologia clássica a tarefa de manter vivos os elementos antigos que certamente fundam toda a cultura europeia, mas que "não estão tão profunda e conscientemente incorporados em nenhuma outra cultura nacional moderna a não ser na alemã" (p. 14), na conferência de 1919 Humanismus als Tradition und Erlebnis ele vai mais além: "na pura luz da criação consciente, para a qual a raça alemã [die deutsche Rasse] está dirigindo-se neste momento, o Antigo torna-se pela segunda vez, e agora em sentido muito mais elevado e espiritual, guia 
e incitamento à recém-nascida cultura do povo" (p. 19: às habituais palavras hegelianas, tais como Geist $\mathrm{e}$ Volk, se alinha aqui precisamente uma nova e temível palavra: Rasse). Convém notar que o axioma da afinidade entre gregos da idade clássica e alemães servia de ocasiāo para deixar à margem, por um lado, o mundo latino (com os seus apelos à romanização), por outro, o mundo eslavo (com a sua tradição bizantina).

Agora o círculo pode fechar-se. O modelo eterno oferecido pelos gregos, na forma espiritual que Platão lhe imprimira, devido à sua peculiar afinidade fatal com a Alemanha, pode então valer como orientação, como modo para indicar ao povo alemão a via para a saída da crise e sanear a nação ferida. Os conteúdos e as direções desta orientação são depois identificados, de diversas maneiras, por cada um dos estudiosos empenhados nesta complexa operação ideológico-cultural.

Nos anos da Primeira Guerra Mundial, Wilamowitz havia posto o seu prestígio pessoal, e o da célebre cátedra berlinense, ao serviço de um engajamento político militante claramente orientado para o nacionalismo prussiano, para o belicismo intransigente, para o autoritarismo guilhermino. Nesta campanha, os grandes adversários eram a democracia parlamentar, o capitalismo inglês (a "cidade dos porcos" de que fala Gláucon no livro II da República era identificada ao Manchesterliberalismus) e, mais tarde, o igualitarismo e o anarquismo bolcheviques. Após a derrota e a crise, escrevia Wilamowitz, em 1918, numa célebre apostila publicada no segundo volume do seu Platon (1919), que se tornou premissa à segunda edição (1920): 
Fui obrigado a ver a autodestruição, a autocastração do meu povo. $\mathrm{Na}$ oclocracia e entre os aduladores velhacos e venais, que ela encontra em todas as classes, não há mais lugar para um velho que não deixa que se arranque do coração - de nenhum Deus, de nenhum homem - a sua honra de ser Prussiano. Só lhe resta morrer. Mas o reino das formas eternas que Platão apresentou é indestrutível, e nós, com a nossa ciência, estamos ao seu serviço; os miasmas da putrefação não penetram no seu puro éter [...]. Combaterei, sob a bandeira de Platão, enquanto viver.

Mas, que leitura faz Wilamowitz no seu Platon? O "estado de justiça” da República (ao qual dedica uma análise bastante breve) parece oferecer-lhe a imagem de um estado corporativo, fundado na concórdia das ordens (Stände) e governado por uma autoridade paternalista. Neste sentido, o ideal platônico parece coincidir com a Prússia de Frederico, o Grande (já Hegel o havia lembrado como exemplo feliz de filósofo-rei), que combinava de maneira justa: solidariedade social, atenção à cultura, primazia na guerra. Regressa, também, a costumeira comparação com a Igreja católica, na sua estrutura hierárquica e na renúncia aos bens terrenos, exceto quanto ao papel desempenhado pela revelação que em Platão, pelo contrário, cabe à ciência; a isto se acrescenta uma interessante referência ao estado jesuítico no Paraguai (Platon, I, pp. 402 segs.). Mas há mais, como traço central da República, Wilamowitz identifica o governo de uma classe de guer- 
reiros e de senhores (Kriegerstand, Herrenstand) que vivem em "casernas" e praticam um "comunismo de guerra" hostil à moleza da vida burguesa (I, pp. 430 segs.); o filósofo platônico parece, pois, um militar dotado de formação científica ou um homem de ciência educado militarmente (I, pp. 444 segs.).

Esta imagem de Platão como restaurador do sentido de estado numa Grécia abalada por guerras intestinas e por um nascente individualismo é reafirmada na conferência de Wilamowitz Der griechische und der platonische Staatsgedanke (1919): corporativismo, autoritarismo e militarismo constituem o modelo que Platão, mestre de política, através do seu intérprete Wilamowitz, indica à sociedade alemã para que ela saia do seu desalento atual.

Werner Jaeger sucedeu ao seu mestre Wilamowitz na cátedra de Berlim e retomou com entusiasmo a proposta de fazer de Platão o guia espiritual do renascimento alemão. Neste sentido, o discurso Die griechische Staatsethik im Zeitalter des Plato, proferido em 1924 por ocasião da celebração do aniversário da fundação do Reich (que, segundo Jaeger, precisava de ser "novamente fundado") e significativamente publicado em 1934, é uma espécie de manifesto programático. Também o movimento do Terceiro humanismo foi fundado por Jaeger e tinha como seu canal a influente revista "Die Antike" (von Popitz foi diretor dessa revista, e do inicial conservadorismo se estendeu até ao nacional-socialismo, tornando-se ministro das Finanças prussiano de 1933 a 1944, quando caiu vítima da repressão que se seguiu à conspiração contra Hitler). A inspiração da leitura jaegeriana de Platão diferencia- 
se da de Wilamowitz em dois aspectos importantes: por um lado, ela está mais próxima de Hegel porque insiste na organicismo do estado e na sua supremacia (enquanto "comunidade de vida", Lebensgemeinschaft) sobre o indivíduo; por outro lado, e pela mesma razão, ela soa perigosamente mais "atual" relativamente à nostalgia de Wilamowitz da época guilhermina e da sociedade prussiana. $\mathrm{O}$ objetivo educativo e também propagandista dos escritos de Jaeger - como os do seu mestre e do seu colaborador Stenzel -, mais do que ser estritamente histórico-filológico, é marcado pelo seu elevado nível de verbosidade muitas vezes retórica que resulta inversamente proporcional à análise precisa dos textos discutidos.

No discurso proferido na celebração, Jaeger insistia sobre o caráter da ética estatal grega elevada, por Platão, a princípio ideal: a supremacia do estado sobre o indivíduo (p. 89), a exigência de "sanidade moral e de simetria da comunidade do povo [Volksgemeinschaft]" ( $\mathrm{p}$. 102). No primeiro volume da sua grande obra Paideia, publicado em 1933, Jaeger volta a atribuir aos gregos uma concepção "orgânica", porque concebe o indivíduo como parte do todo, o que não significa, como acreditava Hegel, que os gregos ignorassem a individualidade cristã, antes pelo contrário antecipam-na (pp. 9-11); a cultura grega superou quer a visão do homem-rebanho, quer a de um "suposto eu autônomo", indo na direção platônica do homem-ideia, cujo objetivo é "imprimir no indivíduo a forma da comunidade", e aqui se manifesta a essência da antiga paideia (p. 16). Esta forma consiste, pois, no "espírito do Estado", escreve Jaeger 
criticando o classicismo de Goethe típico de "uma época ainda impolítica do povo alemão": "o nosso próprio movimento espiritual para o Estado abriu-nos os olhos para o fato de um espírito alheio ao Estado não ter sido menos desconhecido dos Helenos do período áureo, do que um Estado alheio ao espírito" (p. 18). Na unidade viva de estado juntamente com o indivíduo, o primeiro confere ao segundo a sua ética autêntica. Marcas fortemente hegelianas, como se vê, mas ligadas diretamente à atualidade política dos acontecimentos do Reich alemão. $\mathrm{O}$ adversário a abater, outrora e sempre, é o mau individualismo desagregador propagandeado pelos Sofistas. Num artigo de 1928, Die platonische Philosophie als Paideia, Jaeger tinha escrito que os sofistas "fundaram a sua educação numa teoria do Estado e da Sociedade, que se apoiava na ideologia da democracia dominante e fazia do ideal tradicional a fachada de um individualismo totalmente cético-individualista". Deste modo, eles acabaram por formar "uma raça cética e privada de escrúpulos" (p. 164). Num artigo sucessivo, de 1932, Staat und Kultur, Jaeger teria criticado a ameaça que o individualismo democrático representava para a sociedade e o estado alemães.

Faz-se necessário, então, voltar à saudável herança grega (e platônica), fundada, também em Paideia, na apaixonada reivindicação jaegeriana da continuidade entre gregos e alemães. Há "uma conceção da vida dos gregos fundamental, na qual nos sentimos afins a eles em índole e em raça: o heroísmo" (p. 48). Do que se trata, Jaeger irá explicar numa página densa de ecos alarmantes da sua Introdução à Paideia: 
Precisamente em momentos históricos em que, no endurecimento de uma época tardia, o homem vivo sai do seu casulo, onde o obtuso mecanismo exteriorizado da cultura se torna o inimigo do elemento heróico que se encontra no homem, então, por uma profunda necessidade histórica juntamente com a brama de ir beber às nascentes da própria estirpe, deve despertar a necessidade prepotente de penetrar até às camadas mais profundas da existência histórica, onde o espírito afim ao povo grego plasmou aquele fogo, a partir da vida incandescente, na forma que conserva até hoje e imortaliza o instante criativo da sua erupção (p. 8).

São palavras publicadas em 1933, ano em que o Parlamento votou o início do rearmamento alemão, e deste acontecimento o apelo jaegeriano ao "heroísmo" torna-se uma sombra sinistra. De resto, o próprio Adolf Hitler escrevera poucos anos antes (1925-26) em Mein Kampf, insistindo sobre o valor educativo da cultura clássica:

Também o ideal helênico deve ter-nos ficado na sua exemplar beleza [...]. A luta que hoje se avizinha visa um prêmio altíssimo: uma civilização luta pela sua existência, uma civilização que sintetiza em si milênios e engloba a cultura grega junto com o germanismo.

Em todo o caso, trata-se, para Jaeger, de um heroísmo altamente "aristocrático". "É um fato fundamental 
da história da cultura que cada cultura superior surgiu da diferenciação social da humanidade, a qual, por sua vez, deriva da natural diversidade física e psíquica dos indivíduos". Jaeger cita, a este propósito, a eugenia platônica com a sua referência à seleção das raças caninas, e conclui: "A aristocracia é a fonte do processo espiritual da formação da cultura de uma nação" (p. 28). Jaeger decerto não tem mais em mente, ao contrário de Wilamowitz, a tradicional aristocracia junker prussiana, mas uma nova aristocracia do "espírito" e do "heroísmo", com base étnica mais do que hereditária. Os gregos perseguiram exemplarmente, exprimindo "uma suprema vontade com a qual enfrentavam o destino, [...] a formação de uma humanidade superior". E neste sentido, a sua cultura é verdadeiramente fundadora: pelo contrário, quanto a israelitas, chineses e hindus pode falar-se de "culturas" só em sentido antropológico, como efeito de um "mau hábito de nivelamento positivista” (pp. 6 seg.).

Supremacia do estado como forma viva da ética, projeto paidêutico de forjar uma humanidade superior, heroísmo aristocrático como guia do povo: este é, pois, segundo o Jaeger de 1933, o legado dos gregos, e de Platão, ao "destino" afim à Alemanha moderna.

Convém dizer que o tom jaegeriano muda sensivelmente no segundo volume de Paideia, mais especificamente dedicado a Platão: esta parte da obra, embora ainda viesse a ser publicada em Berlim em 1944, foi todavia escrita nos Estados Unidos, onde Jaeger se refugiara em 1936 para impedir que a esposa judia sofresse perseguições raciais (destino verdadeiramente 
trágico para o velho apologista da deutsche Rasse). Aqui o Jaeger "americano" retoma temas próprios da crítica oitocentista a Platão, como o desinteresse pelo "Terceiro Estado", isto é, “a maioria da população" (II, p. 341); e considera totalmente não política a destinação da Academia, cujo modelo de referência era a figura do filósofo alheia às vicissitudes mundanas delineada no Teeteto, uma Academia possível só no contexto da tolerante democracia ateniense, e sinal da "resignação" política de Platão (II, pp. 473 segs.). Trata-se, talvez, do espelho de uma análoga resignação jaegeriana: para Platão, o ideal da Hélade tornar-se-ia o "de uma senhoria de filósofos, construída a partir da capacidade do intelecto investigador do homem de alcançar o conhecimento do Bem divino" (p. 518). Aqui, parece substituir-se mais levemente uma concepção religiosa e quase teocêntrica do destino da política por um "Estado orgânico" e educador, por um espírito heróico da aristocracia.

Este desvio é confirmado pelo terceiro volume de Paideia, publicado em 1947, num novo pós-guerra muito diferente do de Wilamowitz, e após se ter verificado uma segunda tragédia alemã. Não por acaso, Jaeger intitula o capítulo sobre a vicissitude siracusana de Platão A tragédia da paideia, que conduz ao paralelismo entre o filósofo e os tiranos. E também aqui, o "conhecimento do Bem divino" é considerado norma e medida do rei platônico (III, p. 363): uma norma incompreensível para o tirano e também "para a maioria das pessoas, que deixara de ser um povo orgânico, para ser apenas uma massa” (III, p. 350). 
Com este duplo fracasso, face ao tirano e à "massa", e com a consequente passagem da política à "resignação" e ao divino, se completa o retrato platônico desenhado por Jaeger: um retrato que segue fielmente, como se viu, a vida própria de uma parte dos intelectuais alemães entre as duas guerras, entre exaltação nacionalista, perda das esperanças no novo Reich e definitiva derrota.

"Uma consciência cristâ", escreve Jaeger, "encontrará um só ponto de honesto erro na atitude de Platão: o de ter procurado neste mundo aquele reino do espírito que ele queria edificar" (III, p. 368).

Julius Stenzel foi o 'companheiro de aventuras' de Jaeger naquela altura: decerto, mais filósofo do que Jaeger (o seu ponto de referência era o neokantismo de Rickert) e menos afortunado na carreira de filólogo. No que diz respeito ao acontecimento do Terceiro humanismo e à fruição política de Platão, Stenzel se inspirara fielmente no "manifesto" jaegeriano de 1924, aliás, com o seu Platão educador, de 1928, antecipara a grande obra de Jaeger de 1933.

Nessa obra, Platão era visto como expressão de uma "espiritualidade ática" que se tinha contraposto ao racionalismo "iluminista" jônico, e recompunha ciência e paideia, saber e vocação educativa (p. 116). Há uma "analogia externa de eventos, que reúne o nosso tempo ao tempo de Platão", e uma mais íntima, que consiste precisamente na luta contra aquele subjetivismo iluminista outrora promovido por aquela sofística grega contra a qual se lançara também Jaeger. Ao refletir sobre o movimento dialético hegeliano, que 
via Platão "superado" pelo princípio da subjetividade, Stenzel escreve no ensaio Hegels Aufassung der griechischen Philosophie, de 1932:

Por excesso de má subjetividade nós sonhamos o regresso à substancial comunidade de Platão. 2000 anos separam Hegel de Aristóteles; ele disse-nos o que existe no meio e mudou a cara do mundo: a nova liberdade do eu. 100 anos separam-nos de Hegel. O que aconteceu nestes poucos anos? A liberdade do eu tornou-se débil, a dialética real deu um passo em frente. O passo da humanidade liberal-individualista à comunidade da nação caracterizada como individualidade [individuell characterisierte Gemeinschaft der Nation] cumpriu-se, num primeiro momento, como antítese barulhenta, que espera pela síntese (p. 317).

Esta estranha "dialética" leva-nos, portanto, além de Hegel e do liberalismo individualista, para trás, até à "comunidade orgânica", e dela até Platão: "Platão deve, hoje mais do que nunca, ser para nós mestre e guia nos princípios fundamentais" (Plat. ed., p. 117). Segundo Stenzel, quais são esses princípios? O primeiro deve ser atribuído à "enorme potência da comunidade estatal, que forma o indivíduo e o eleva além de si mesmo": só ao assumir o estado como tarefa o indivíduo se torna verdadeiramente "pessoa" (p. 120). O segundo princípio reside em aceitar a condução dos chefes deste estado. A paideia platônica não se dirigia 
a todos, mas só aos governantes da estrutura estatal, e isto era uma vantagem para todos os cidadãos.

Portanto, todos devem sentir a subordinação à condução da classe dirigente como cumprimento [...] da própria felicidade. O que a autoridade dos filósofos sobre a massa dos artesãos faz é cumprir a sua própria vontade, só que nem sempre é clara a eles mesmos [...]. Da ideia da personalidade do Estado, viva nos chefes, todos recebem a sua pessoal dignidade e liberdade (p. 122).

Nunca em outras ocasiōes o Terceiro humanismo se aproximou a tal ponto da doutrina do Führerprinzip como nestas páginas de Stenzel.

Platão inspirou toda a sua vida neste princípio de governo filosófico. Stenzel não duvida da veracidade da Carta VII como documento que testemunha o engajamento na ação política direta; reconhece no Político elementos de "cesarismos", porém sempre ao serviço da meta paidêutica da República (a formação do indivíduo na comunidade estadual); e nega, por fim, o caráter utópico do projeto platônico, citando o sucesso dos acadêmicos Erasto e Corisco junto de Hermia, o tirano de Atarneu (pp. 109 seg.). À parte os seus muito notáveis desenvolvimentos filosóficos, o Platão educador de Stenzel coloca-se plenamente, no que diz respeito ao pensamento político de Platão, no caminho que, partindo de Wilamowitz, conduz ao primeiro volume de Paideia - e, como veremos, ainda mais além. 


\section{A USURPAÇÃO NAZI DE PLATÃO}

1933 - o ano da ascensão de Hitler ao poder e ano também da publicação do primeiro volume de Paideia - pode ser considerado o momento crucial da apropriação do pensamento político de Platão por parte da ideologia nacional-socialista: um evento que, como veremos, teria consequências duradouras na interpretação deste pensamento não só na Alemanha.

Certamente, o processo já estava em curso e, de alguma forma, já oficializado, se Gottfried Feder, em 1927, ao expor a Weltanschauung pertencente ao programa NSDAP, pôde escrever:
A vontade da forma, a vontade de libertar-se do caos, de repor a ordem no mundo saído da ruína e de governar a ordem como guardi- óes [Wächter] no mais alto sentido platônico: eis a tarefa imensa que o nacional-socialismo se atribuiu como objetivo.

Tudo isto encontrava a sua formulação "científica" mais madura no grande livro de Kurt Hildebrandt, Platão. A luta do espírito pela potência, além de no seu explícito - porque de afortunada divulgação - prefácio à República, ambas as obras publicadas em 1933. O mesmo subtítulo da obra maior indicava com precisão o background de referência de Hildebrandt: se Geist remetia genericamente à tradição hegeliana, Macht era indubitavelmente uma referência a Nietzsche, e Kampf era uma referência ao escrito programático de Hitler. 
Ainda em 1933, de resto, aparecia o livro do nazi Joachim Bannes, cujo título explícito era Platons Staat und Hitlers Kampf.

$\mathrm{Na}$ verdade, Hildebrandt decerto podia encontrar facilmente na literatura platônica do Terceiro humanismo mais do que um elemento congênito, como os temas do estado orgânico, do domínio de uma aristocracia do espírito, do heroísmo fundador. A propósito des-te último, é rápida a assonância também estilística entre a página de abertura de Platão e a já citada de Paideia: se Platão não realizou o seu plano na Atenas contemporânea, visto que "nos reinos espirituais não é a momentânea aquisição de poder que decide, é porque o calor da poderosa necessidade pode vir inesperadamente à luz nas gerações dos bisnetos" (p. 4, cf. p. 43). Mas Hildebrandt limita-se a citar a obra de Wilamowitz, que considera indispensável, mesmo discordando dela. Pelo contrário, os seus predecessores indicados são Nietzsche, o "grande adversário" de Platão que, porém, compreendeu "profundamente na alma" a paixão política, e depois o círculo de Stefan George, em particular a obra de Kurt Singer sobre Platão o fundador, de 1927, que oferecia a imagem de Platão como profeta místico, inspirado e heróico (pp. 8, 487).

No que diz respeito a Nietzsche, a referência explícita de Hildebrandt encontra-se no parágrafo I, 261, Os tiranos do espirito, de Humano, demasiado humano, onde se diz que "Platão foi o desejo que se realizou, de se tornar o sumo legislador filosófico e fundador de um Estado". Não há dúvida, porém, de que ele tinha em mente também textos como os dos aforismos 957 - 
961 de Vontade de poder, onde Platão não é mencionado explicitamente, mas se evoca
uma raça de dominadores, os futuros "senho- res da terra" - uma aristocracia nova, prodi- giosa, edificada sobre a mais dura legislação de si, na qual se dê à vontade de filósofos violentos e de artistas tiranos a possibilidade de durar milênios [...] para modelar artistica- mente "o homem".

Em tudo isto, Hildebrandt podia facilmente reconhecer os traços centrais da sua leitura de Platão.

Pelo contrário, ele polemiza muitas vezes contra a crítica nietzschiana ao Platão "socrático", isto é, ascético e moralista, e ao Platão dialético, em quem o filósofo reconhecia "uma péssima e pedante capciosidade conceitual” ( $V P, \$ 427)$. A recusa de ambos os traços formará, como veremos, o esqueleto teórico da interpretação de Hildebrandt. Ele ignora, porém, compreensivelmente, um outro aspecto do ataque de Nietzsche a Platão, talvez o mais interessante da obra de 1878 . Platão é caracterizado (talvez seguindo Grote, e certamente antecipando Pöhlmann) como "o antigo, típico socialista na corte do tirano siciliano". O socialista deseja e favorece o estado ditatorial cesarista de entấo e de hoje, porque deseja tornar-se seu herdeiro:

precisa da mais servil sujeição de todos os cidadãos perante o Estado absoluto [...]. Por isso, prepara-se secretamente para dominar pelo 
terror e como um prego inculca na cabeça das massas semicultas a palavra "justiça”, para privá-las completamente do seu intelecto.

O "grito de guerra" do socialista é, pois, "Quanto mais Estado for possível” (Humano, demasiado humano, I, $\$$ 473). E ainda: "A melodia utópica fundamental de Platão, que hoje é cantada ainda pelos socialistas, repousa sobre um defeituoso conhecimento do homem": suprimir a propriedade, e com ela a vaidade e o egoísmo, significaria, de fato, segundo Nietzsche, suprimir todas as virtudes humanas (ivi, II, $\$ 285$ ). Desta crítica nietzschiana ao Platão socialista, que tem certamente tons proféticos, não resta em Hildebrandt nenhum vestígio.

Aos outros vestígios, como se dizia, se dirige todo o seu empenho teórico. Em primeiro lugar, delineiase uma imagem decisivamente irracionalista do pensamento platônico. Platão não foi o filósofo do conceito, da sutileza dialética, da árida ciência: não é de Hegel que deve ser aproximado, mas de Schelling e de Schopenhauer. Nele dominam a intuição, a criatividade espiritual, a vontade heróica, a fé numa nova religião. Platão, escreve Hildebrandt, "quer uma sapiência que encontre lugar numa alma individual heróica, que traga em si o futuro de todo o povo" (p. 43). A doutrina que não pode ser escrita de que fala a Carta VII não é certamente uma "ciência positiva", mas uma religião cósmica e política, cujo principal documento é o Timeu: "Platão é o fundador de uma religião cujos ministros são ditadores, corpos legislativos e reis" (pp. 411, 414). 
Junto da acusação de conceitualismo dialético abstrato, deve ser refutada a imagem do Platão ascético, inimigo da corporeidade e do eros. No Cármides, Hildebrandt lê a sensualidade platônica, a irrelevância da sobrevivência de uma alma privada de corpo. A tarefa da filosofia é "a criação do homem perfeito" no corpo e na alma: "no momento em que o verdadeiro kaloskagathos obtivesse o poder sobre a terra, a terra seria perfeita" (pp. 112 seg.). Além do óbvio eco nietzschiano, Hildebrandt parece aqui repropor a célebre tese do ideólogo nazi Alfred Rosenberg, que no seu livro de 1930, Der Mythus der XX. Jahrhunderts, tinha reconhecido em Platão o inspirador do projeto da criação de um "tipo racial" perfeito tanto no corpo quanto no espírito.

A leitura cristianizante do Górgias e do Fédon é, segundo Hildebrandt, infundada. "O reino de Platão é deste mundo!" (p. 154). Se o Fédon está destinado sobretudo à batalha contra o "terrível inimigo" representado pelo materialismo, ele não sugere a fuga ascética do mundo, mas uma "configuração bela" do próprio mundo; e não tem no centro nem as doutrinas da imortalidade da alma e das ideias, nem "a onipotência da alma purificada e voltada para o eterno", em que consiste a "felicidade da vida platônica" já na terra (pp. 214-20). Em todo o caso, insiste razoavelmente Hildebrandt, o Fédon não pode ser lido ("cristâmente") sem ter em conta o Banquete, a República e o Fedro, nem estes diálogos devem ser interpretados só com base no Fédon (pp. 213 seg.). Por sua vez, o Fedro não oferece uma teoria da imortalidade da alma, mas 
uma "figuração simbólica" da vida interior de Platão, uma espécie de confissão em forma mítica. De fato, no centro do diálogo estaria o amor de Platão por Díon: prova disso é a afirmação "nós [scil. Platão e Díon] seguimos Zeus" (250d), e indício disso é o uso de formas oblíquas do nome do próprio Zeus (dios, etc.) que aludem precisamente ao nome do amado príncipe siracusano (p. 343).

Platão heróico, portanto, que considera inseparável a beleza dos corpos da beleza do espírito, que situa o seu reino neste mundo e não no além: tão pouco ascético quanto conceitual e dialético.

Trata-se, como se vê, de teses certamente opináveis mas não de todo infundadas ou privadas de precisas referências textuais. Todavia, é na reconstrução da "biografia política" de Platão - conduzida através do exame dos diálogos por ordem cronológica - que o discurso de Hildebrandt alcança tons francamente surreais, embora conduzida com atenção quer pelas análises pormenorizadas, quer pelas exclamações retóricas. Tanto mais que, em contraluz, faz-se coincidir esta biografia, até certo ponto, com a de Adolf Hitler, uma menção somente implícita na obra maior, mas tornada explícita na introdução à República (p. XI).

No início está naturalmente a "paixão política" de Platão, uma figura em que "se enraízam as forças espirituais e psíquicas fundamentais da cultura europeia”, uma "divindade renovadora, lá onde a seiva da vida estagna” (pp. 4 seg.). A tarefa que Platão desde o início assumiu para si, com a "potência do grande homem de Estado", era a de "fazer renascer o Estado ático" 
(p. 36), num momento em que a nação está ameaçada pelo caos, "que em lugar nenhum se anunciava tão terrível como em Atenas"; um caos cujos artífices eram os demagogos atenienses e os sofistas "iluministas" (p. 65). Após a morte de Sócrates, Platão decide "gerar a nova mentalidade estatal com novos seguidores"; a "profecia" de Sócrates no fim da Apologia (39c-d) mostra que Platão sente em si "a força da vitória” (p. 85). Convém notar desde já que este tema da "vitória" volta no livro de maneira obsessiva, quase como se recordasse ao leitor as vitórias memoráveis hitlerianas de 1933. No Protágoras, o encontro com o jovem Hipócrates e o combate com Protágoras sobre a virtude delineiam o projeto de Platão que consiste em selecionar os jovens melhores, em fundar um conjunto de seguidores para reformar a vida da comunidade (p. 34). A discussão sobre a coragem no Laques não deixa espaço para dúvidas: Platão dirige-se à juventude, "exultante de vitória e certo da sua força dominadora e educadora"; a sua intenção é recolher "discípulos incondicionalmente devotos, com os quais possa determinar a constituição e realizar a nova espiritualidade. A coragem era a qualidade necessária. Só quem desprezava o perigo da morte podia ser seu verdadeiro seguidor" (p. 105): aqui, o leitor pode escolher pensar na Hitlerjugend ou nas SA.

O Górgias representa, porém, o momento de reviravolta e da decisão na façanha política do jovem Platão, tal como resulta do confronto de SócratesPlatão com Cálicles. Desta personagem Hildebrandt reconhece a afinidade nietzschiana e também - pela 
sua "moral dos dominadores" - uma certa proximidade com Platão, que não pode partilhar, contudo, os "desejos animalescos" e a recusa da justiça. Este é o momento fatal em que Platão

\begin{abstract}
via ruir a nação, estava convencido de trazer em si a força salvadora, acreditava que tinha chegado a sua hora, e parecia que não faltava outra coisa senão a mais fácil: a decisão do povo de deixar-se guiar por ele.
\end{abstract}

Mas Platão, discípulo de Sócrates, recusa a tentação à maneira de Cálicles de se aliar com os demagogos atenienses e de exercer um poder sem justiça; depois do Górgias, ele recusa apoderar-se imediatamente do governo ateniense e volta-se para a Sicília (pp. 157-60, 165). Uma renúncia não definitiva, porque tentaria uma reconciliação no Menexeno (p. 180) e depois ainda na República, onde (no livro IX, 592) ele formularia a última vã oferta aos atenienses de se decidirem a passar-lhe o poder, sob pena de desaparecimento da história da grande cena (pp. 325 seg.).

Para voltar à recusa posta em cena no Górgias, depois dela Platão voltar-se-ia para a fundação de um "Estado espiritual", destinado a dar os seus frutos políticos só passados muitos anos (aos seus olhos, calculável em dezenas de anos, mas em séculos e milênios aos olhos da posteridade) (p. 165); seguindo esta via, Platão sentia-a verdadeira pelo fato de ter encontrado os Pitagóricos, que tinham fundado uma espécie de ordem de cavaleiros teutônicos na Magna Grécia (p. 
168). O encontro com Alcibíades no Banquete representa a decisão de Platão de dedicar as suas energias à "reunião de sapiência e força", "reconstrução do povo", formação de reis-filósofos, e é prelúdio, portanto, diretamente para a República (p. 266).

É bastante surpreendente que Hildebrandt dedique as suas páginas relativamente mais equilibradas à exposição deste diálogo. Por exemplo, há uma boa reconstrução da peculiar atmosfera do livro I e uma análise inteligente do livro IV. Sobre o tema dos filósofos-reis, Hildebrandt observa com razão que não há nada de utópico, se se recordar a tradição tipicamente helênica de personagens como Pitágoras, Parmênides, Heraclito, Empédocles, que tinham unido, ou aspiraram unir, saber e poder; quanto à versão mais recente da soberania - a do tirano -, Platão veria aí "o pior inimigo e ao mesmo tempo o ideal do renovador do Estado", uma tensão que a crítica posterior, de fato, pôs em evidência (pp. 273-6).

A propósito da sociedade primitiva e sã do livro II, Hildebrandt partilha o sarcasmo de Gláucon acerca da "cidade dos porcos", porque reconhece nela o detestável "Estado pacifista, medroso e conservador" (p. 281). Quanto à tripartição social do livro IV, ele recusa a tranquilizadora versão de Zeller (e oitocentista) que aí lia a instituição das classes de produtores, de militares e de funcionários-professores, para reconhecer, ao contrário, por um lado, um "povo de camponeses e artesãos sem direitos e sem educação", por outro, uma "casta da nobreza", articulada em guerreiros e governantes (p. 288). Ao invés, Hildebrandt passa 
por cima do "comunismo" do livro $\mathrm{V}$, limitando-se a mencionar o esforço de persuadir os comerciantes a renunciarem ao poder, e os governantes a renunciarem à propriedade privada.

No seu conjunto, o desenho utópico da República, que não encontra um grande interesse por parte do nosso autor, parece-lhe - desta vez, de acordo com muitos intérpretes do século XIX - ter sido, em boa parte, realizado pela Igreja católica, com a sua hierarquia e o celibato eclesiástico, além de, pela específica união de guerreiros e religiosos, pelas ordens de cavaleiros medievais (uma e os outros reforçados pelo "sangue jovem” dos povos germânicos) (pp. 5, 444 seg.).

$\mathrm{O}$ que mais importa a Hildebrandt é que, caindo no vazio mais um apelo ao povo ateniense lançado na República, Platão se volte para a recusa à tomada direta do poder, entrevista na relutância dos filósofos-reis em governar. Após o grande diálogo, Platão se teria dedicado inteiramente à Academia, deixando aos outros - isto é, ao predileto Díon - a tarefa de agir (pp. 308, 380). Assim, o Político evoca a figura do "ditador", indicando a Díon a via a seguir na Sicília (p. 397). E é precisamente Díon a obter, por conta de Platão, aquele "triunfo" que o mestre esperava; depois dele, a escola platónica passa de vitória a vitória, de Timoleonte até Alexandre, que encarna plenamente o ideal do kaloskagathos platônico (pp. 405-29). Por fim, nas Leis, Platão teria escrito o manual destinado aos futuros membros da assembleia constituinte da Sicília, proposta por ele na Carta VII (p. 482).

A decisão de Platão de recusar a ação política direta, para se dedicar à construção de um "reino espiritual" 
e à formação dos discípulos, longe de significar uma derrota política, seria a premissa para uma "vitória" mais completa e duradoura, na imediatez da história grega sucessiva, e, em seguida, por séculos e milênios até à definitiva vitória póstuma em 1933.

Hildebrandt trata apenas de raspão, e em certa medida, a eugenia do livro V: para o "meio heróico" que consiste na eliminação dos deficientes apela-se mais uma vez a Nietzsche (pp. 295, 488). Mas a questão vai tornar-se, entretanto, central em outra corrente da ideologia nacional-socialista, do já citado livro de Rosenberg ao opúsculo de Hans Friedrich Karl Günther, Platão guardião da vida. A fortuna deste livro, e do seu autor, é digna de nota: publicado em 1928, ele teve durante a época hitleriana vinte impressões, num total de 120.000 cópias, e Günther obteve em 1935 a cátedra de antropologia política na Universidade de Berlim. O que é ainda mais surpreendente é que uma terceira edição da obra tenha aparecido em 1965, com uma introdução do autor que confirmava a validade, embora se distanciasse de alguns "abusos", das leis eugenéticas alemãs de 1933, segundo ele, largamente justificadas quer pela genética moderna, que por processos análogos adotados nos países anglo-saxões, em primeiro lugar, nos Estados Unidos.

Portanto, Platão, por índole, ações e feições era "homem essencialmente nórdico", isto é, pertencia à raça dos dominadores "louros" que tinham submetido as populações autóctones (pp. 17, 46): é difícil não pensar aqui no precedente de Nietzsche, com a sua "raça loura dominante, ou seja, a raça ariana dos 
conquistadores" (Genealogia da moral, $\$$ 5). Segundo Günther, a guerra do Peloponeso tinha quase extinto esta raça, e daí nascem as preocupações eugenéticas que Platão desenvolve na República.

De fato, Platão tinha claramente consciência das raízes biológicas da kalokagathia: tanto a virtude quanto a beleza somática são "questões de raça", de "estilo racial”, razão pela qual é perfeitamente lícito atribuir-lhe um "racismo da alma” (pp. 28, 64-7). Não há dúvida de que também em Platão a educação desempenha um papel importante, mas, ao contrário do "sofista Rousseau", ele nunca pensou que todos os homens fossem igualmente educáveis e que a educação pudesse cancelar as diferenças biológicas: aqui a sua posição é confirmada pela eugenia e pela higiene racial dos modernos, de Gobineau a Mendel e Galton (pp. 28 seg.). Os filósofos-reis deverão ser "homens de sangue puro" (Günther traduz deste modo o gnesioi em República VII 535c9), contrapostos aos homens de teor oriental que enchiam a sofística (p. 36).

Além da eugenia do livro V da República, Günther encontra os seus textos de referência no mito das raças "metálicas" do livro III, 415 (esquecendo-se do declarado carácter de "nobre mentira”), e na supressão dos doentes com defeitos genéticos prescrita sempre no livro III, 409e seg. Também no livro IX das Leis e no Político se prevê o recurso à "pena de morte como purificação da estirpe” (pp. 29, 47-50).

Também por este aspecto o espírito helênico se revela afim ao espírito germânico, uma vez que elimina o "sedimento cristão medieval" que abre a passagem 
ao igualitarismo do homem-massa moralista e se mostra cientificamente insustentável (p. 57). Portanto, exclama Günther, "é um bem [...] que na nossa pesquisa da Kultur, que visa provocar uma melhoria do homem através da seleção, tenha marchado à nossa frente um espírito criador como Platão" (p. 80). Um Führer, este, demasiado severo se, como observa de forma benevolente Günther, a eugenia moderna aparece mais dócil do que a platônica, porque não chega a eliminar os indivíduos inferiores, limitando-se a impedir a sua reprodução, através da esterilização, e o acesso à educação superior (o resto, pelo menos segundo a edição de 1965, não pertence à "providente legislação" de 1933, mas às suas "insensatas distorções" não bem especificadas).

Já em 1933 as linhas de fundo da usurpação nacional-socialista do pensamento político de Platão pareciam nitidamente marcadas. Por um lado, a aspiração à potência de uma "heróica" aristocracia do espírito, voltada à salvação do povo e do estado, com Hildebrandt; por outro, a eugenia voltada para a pureza racial, com Günther. No fundo, encontrava-se a afinidade entre as virtudes guerreiras dos gregos e dos alemães, a luta contra os "sofistas" iluministas e "burgueses", o sentido da decisão fatal confiada a um Führer (Platão, Hitler, ou quem quer que fosse) e a uma elite capazes de guiar a nação para o seu renascimento. Mas para definir a suposta afinidade entre este Platão e o nacional-socialismo, é oportuno passar a palavra a um neonazi italiano, Adriano Romualdi, que ainda em 1965 podia estabelecer estes elementos de continuidade: 
a identificação do Estado com a minoria heróica que o rege, o fervoroso sentimento comunitário, a educação espartana da juventude, a difusão de ideias-força por meio do mito, a mobilização permanente de todas as virtudes cívicas e guerreiras, a concepção da vida pública como espetáculo nobre e belo onde todos participam [...]. Dificilmente Platão se teria escandalizado com a pira dos livros "corruptores" ou com as leis para a proteção do sangue. Claras influências platônicas encontram-se também na doutrina interna das SS empenhadas em submeter a uma paciente seleção física e espiritual os futuros chefes, criados nas Ordensburgen, as "fortalezas da ordem" surgidas um pouco em toda a Alemanha. A Ordnungsstaatgedanke, a concepção do Estado como ordem viril que se identifica com a vontade política, parece-nos uma revivescência das ideias da República (p. 54).

Podemos perguntar-nos: há algum método neste delírio? Certamente os ideólogos nacional-socialistas podiam apoiar-se numa prestigiosa tradição filológica, de Wilamowitz a Jaeger e Stenzel. O seu conhecimento dos textos platônicos é, sem dúvida, de primeira mão, e, salvo algumas exceções, as referências a alguns lugares platônicos são irrepreensíveis. O efeito deformador derivou, antes de tudo, do uso linguístico da tradução, cujas premissas (dissemos) remontam a Hegel, e ao qual se acrescenta a utilização extensiva de uma linguagem retórica de matriz nietzschiana. Em segun- 
do lugar, encontram-se os drásticos cortes operados no texto platônico, como a separação da política da ética e da dialética, a desvalorizada legitimação do poder mediante o saber e, também, no terreno especificamente político, o silêncio sobre a instância de fraternidade e de solidariedade entre todos os cidadãos; para não falar - a propósito da seleção da classe dirigente - da introdução da afinidade imaginária de raça e de "sangue" em vez dos dons intelectuais e morais. Um Platão amputado e reescrito desta forma pode efetivamente tornar-se disponível à leitura ideológica nazi, embora nenhuma destas operações tornem minimamente plausível a leitura de todos os diálogos em chave de autobiografia política. Naturalmente, a isto se acrescenta - para garantir a sua derivação do modelo platônico - uma imagem idealizada e propagandista da natureza e das intençôes do regime hitleriano.

O dano provocado pela usurpação nazi de Platão vai, todavia, além da construção daquela sua imagem deformada que dominou a cultura alemã dos anos Trinta. Infelizmente, ela foi aceita e partilhada também fora dos confins da Alemanha e da duração do regime, produzindo, na história das interpretaçóes novecentistas, duas atitudes igualmente desviantes: a condenação de Platão, por parte dos adversários do nazismo que, porém, defendiam aquela imagem, e, por oposição, a sua defesa, que pretendia cancelar, igualmente de forma arbitrária, todos os elementos que tinham contribuído para a formação dessa imagem. 
NOTA BIBLIOGRÁFICA

Sobre o papel do classicismo na cultura alemã do século XX, cf. em geral L. CANFORA, Ideologie del classicismo, Torino: Einaudi 1980; mais especificamente acerca de Platão, ID. Platon im Staatsdenken der Weimarer Republik, in H. Funke (Hrsg.), Utopie und Tradition. Platons Lehre vom Stat in der Moderne, Würzburg: Königshausen-Neumann 1987, pp. 133-47.

As citações de Wilamowitz foram retiradas de U. VON WILAMOWITZ, Platon, Berlin, Weimannsche Buchhandlung, 19202 (sobre a República, cf. vol. I, pp. 393-449; vol. II, pp. 179-213). Acerca das posiçōes políticas de Wilamowitz, $c f$. L. CANFORA, Cultura classica e crisi tedesca. Gli scritti politici di Wilamowitz, 1914-1931, Bari: De Donato, 1977 (contém a tradução da Postilla ao Platon). Especificamente sobre Platão, $c f$. M. ISNARDI PARENTE, Rilegendo il "Platon" di Ulrich von Wilamowitz, in "Annali della Scuola Normale Superiore di Pisa", série III, vol. III, 1 (1973), pp. 147-67.

As citações de W. JAEGER foram retiradas de Paideia, 3 vols., tradução italiana, Firenze: La Nuova Italia, 1936, (19532)-59; para artigos e conferências da Humanistische Reden und Vorträge, Berlim: De Gruyter, 1960. As citações de J. STENZEL foram retiradas de Platone educatore, tradução italiana, Bari: Laterza 1966; para artigos e conferências da Kleine Schriften zur griechischen Philosophie, Darmstadt: Wissenschaftliche Buchgesellschaft 1956.

Sobre Platão e o Terceiro humanismo, cf. F. FRANCO REPELLINI, Note sul "Platonbild" del terzo umanesimo, in "Il Pensiero", XVII (1972), pp. 91-122; sobre Jaeger, em particular vejam-se os ensaios recolhidos no mesmo 
fascículo de "Il Pensiero". Cf. também os ensaios de C. H. KAHN, Werner Jaeger's Portrayal of Plato, e de D. H. WHITE, Werner Jaeger's "Third Humanism" and the Crise of Conservative Cultural Politics in Weimar Germany, in W. M. Calder III (ed.), Werner Jaeger Reconsidered, Atlanta: Scholars Press 1992 (pp. 69-81 e 267-88).

Para o background cultural do nacional-socialismo e, em particular, para a influência do George-Kreis, cf. F. FISCHER, Assalto al potere mondiale, tradução italiana, Torino: Einaudi, 1965; G. L. MOSSE, Le origini culturali del Terzo Reich, tradução italiana, Milano, Mondadori, 1968; G. LUKÁCS, La distruzione della ragione, tradução italiana, Torino: Einaudi, 1959; M. ISNARDI PARENTE, Platone politico e la VII epistola, in EAD., Filosofia e politica nelle lettere di Platone, Napoli: Guida, 1970, pp. 168-204.

Sobre Nietzsche e Platão, cf. V. GOLDSCHMIDT, Platonisme et pensée contemporaine (La querelle politique, pp. 135-75), Mayenne: Aubier Montaigne, 1970. Os textos nietzschianos são retirados de F. NIETZSCHE, Umano, troppo umano, a cura di M. Montinari e S. Giametta, 2 vols., tradução italiana, Milano: Adelphi, 2002, e de La volontà di potenza, a cura di M. Ferraris e P. Kobau, tradução italiana, Milano: Bompiani, 1992.

Sobre a usurpação nazi de Platão, além do já citado ensaio de Canfora de 1987, e às já mencionadas notas de M. Isnardi Parente a Zeller-Mondolfo, $c f$. sobretudo T. OROZCO, Die Platon-Rezeption in Deutschland um, 1933; in I. Korotin (Hrsg.), Die Besten Geister der Nation Philosophie und Nazionalsozialismus, Wien: Picus, 1994, pp. 141-85; S. FORTI, Biopolitica delle anime, in "Filosofia politica”, XVII (2003), pp. 397-417; EAD., The Biopolitics of Souls: Racism, Nazism, and Plato, in "Political Theory", 34 (2006), pp. 9-32. 
Os textos citados são: K. HILDEBRANDT, Platone. La lotta dello spirito per la potenza (1933), tradução italiana, Torino: Einaudi, 1947 (mas a tradução foi dada a Giorgio Colli com um contrato de 1943); ID., Introduzione a Platon. Der Staat, Stuttgart: Kröner, 1933 (1939); H. F. K. GÜNTHER, Platone custode della vita (1928, 19653), tradução italiana, Padova: Edizioni AR, 1977; A. ROMUALDI, Platone, Roma: Volpe, 1965. Mein Kampf é citado em Canfora, Ideologie del classicismo, cit. Para o programa de partido nacional-socialista, $c f$. G. FEDER, Der Programm des NSDAP und seine Weltanschauliche Grundgedanken (1927), München: Nazionalsozialistische Bibliothek, Heft 1, Weiß'sche Buchdruckerei, 1935. Para a receção da República na cultura alemã, $c f$. o vasto repertório bibliográfico de U. ZIMBRICH, Bibliographie zu Platons Staat, Frankfurt am Main: Klostermann, 1994. 
(Página deixada propositadamente em branco) 


\section{5.}

\section{PLATÃO NO OCIDENTE ENTRE AS DUAS GUERRAS: FRANÇA, ITÁLIA, INGLATERRA}

\section{PLATÃO POLÍTICO EM FRANÇA}

Ta serena França dos anos trinta, naturalmente o cli1 ma cultural é muito diferente do da febril Alemanha pós-bélica - entre Weimar e o nacional-socialismo - e da sua ansiosa busca de modelos antigos inteiramente utilizáveis na reconstrução social e moral do Reich.

Todavia, não muito diferente é a acentuação do caráter eminentemente político e "engajado" do pensamento de Platão, que aparece tanto na relevante introdução de Auguste Diès à edição Budé da República (1932), quanto no magistral Platão de Léon Robin, de 1935 (ambos autores de inspiração católica em sentido lato).

Segundo a peremptória e feliz fórmula de Diès, "Platon n'est venu à la philosophie que par la politique et pour la politique". Apoiando-se, como é natural, na Carta VII, Diès acrescenta que a filosofia foi origi- 
nalmente, para Platão, só action entravée, ação à qual se renuncia provisoriamente só para a poder realizar de modo mais seguro (p. V). A Academia é, pois, a forma socrático-platônica da tradicional hetairia política aristocrática (porém, onde à primazia da política se integra a da verdade, em que as ideias constituem o nível normativo da práxis) (p. VIII). Em seguida, a atitude de Platão - escreve Diès antecipando, de alguma forma, a linguagem de Hildebrandt - oscila entre uma renúncia duradoura à política, imposta pela hostilidade do ambiente histórico, e a "espera ardente do momento em que se conquistará ou converterá o poder”. Com efeito, quando lhe pareceu possível, Platão estava pronto a enfrentar qualquer risco para realizar a sua ideia dominante de uma Cité sainte (p. IX).

Perante a "enormidade" das propostas platônicas sobre o comunismo de bens e mulheres, Diès afirma justamente que "ninguém é tão radical como um idealista": idealismo e radicalidade não separados de uma certa dose de realismo, porque Platão leva ao limite extremo experimentos sociais presentes em Creta, em Esparta, entre os Citas mencionados por Heródoto e, no que diz respeito à eugenia, no élitisme naturel das cidades gregas (pp. XLVII seg.).

Robin partilha com Diès a politização extrema de Platão: para ele, "ser filósofo ou ser homem de Estado é a mesma coisa" (p. 200). Mas a sua avaliação dos conteúdos do pensamento político de Platão é mais articulada e também mais crítica. $\mathrm{O}$ problema para Platão, em política como em cosmologia, é que o idêntico discipline o diverso, a forma discipline a ma- 
téria informe, a inteligência discipline o caos. A cidade justa é, pois, uma obra a "ser fabricada", por mãos de demiurgos humanos em vez de divinos, um produto da técnica política.

Deste ponto de vista, Robin identifica como tema central no pensamento político de Platão o tema da constriçãao. Os não-filósofos não podem regular de modo autônomo a própria vida segundo a justiça: deve-se, portanto, "subjugá-los e mantê-los sob custódia". A República adota então uma dupla estratégia. Por um lado, pretende "organizar a constrição: ao criar a classe intermédia dos Guerreiros, a constrição é posta finalmente nas mãos dos Filósofos, ao serviço da inteligência"; por outro lado, "para evitar uma revolução militar que voltaria a Força contra a Sabedoria”, devese "organizar um amestramento da Força" mediante um assíduo esforço educativo. A moralidade da cidade consiste, portanto, no saber dos filósofos no poder, e de resto, na "observância de uma obediência que pode ser, por vezes, colaboração, por vezes, servidão" (pp. 191 seg.). Se a história produz uma determinação do social por obra do individual, o objetivo fundamental de Platão é, pelo contrário, conseguir, "por natureza", uma determinação do individual por obra do social.

Neste quadro, os filósofos devem ser concebidos como "a inteligência do ser social", os guerreiros como a sua "energia disciplinada", o resto dos cidadãos como simples escravos de impulsos privados de regras. A unidade da cidade deve resultar de uma solidariedade que é o êxito de uma integração ordenada e hierárquica de funções distinguidas segundo dotes e inclinaçôes dos diversos grupos que a compõem. 
O "comunismo" platônico deriva da intenção de suprimir as estruturas que se opóem a esta unidade, como a propriedade privada e a família. E aqui reside, nota perspicazmente Robin, a ilusão de Platão. Ela consistia em acreditar que, "suprimindo o objeto do desejo" (a característica privada dos afetos e interesses), se suprimia também "o desejo em si mesmo" (p. 196). Com efeito, pode-se observar que esta persistência do desejo constituiria o problema antropológico central de todos os coletivismos do século XX.

Como instaurar a cidade ideal? Robin foi o primeiro, que eu saiba, a falar de um "golpe de Estado do qual nascerá a cidade futura”, referindo-se à expulsão de todos os adultos da cidade, prevista no livro VII da República, como medida inicial para a sua reforma.

Além da República, o percurso platônico delineado por Robin soa de perto - de maneira tão surpreendente como significativa - ao que Hildebrandt tinha reconstruído na sua biografia imaginária. O Político teria sido escrito depois dos primeiros sucessos de Díon na Sicília: nele Platão tinha visto o futuro filósofo-rei (p. 14), e esses sucessos faziam prognosticar a próxima realização dos planos platônicos, em forma de poder justo desvinculado das leis existentes (pp. 200-4). As mesmas Leis, escritas após o fracasso de Díon, não renunciariam à esperança do advento de um novo Díon: Robin insiste justamente sobre passagens muitas vezes descuradas do diálogo, onde Platão desenha a figura de um chefe autocrático capaz de reformar eficazmente a cidade (IV 709d segs., IX 875c segs.). Todavia, esta esperança é "atualizada indefinidamente"; em 
vez da constrição, as Leis apontam sobretudo para a persuasão, mediante os preâmbulos às próprias leis, e pretendem fornecer um "catecismo do bom cidadão" que vise a uniformidade das mentes (pp. 206-14). Se as Leis desenham uma sociedade sustentada por um regime de "democracia temperada", a soberania última pertence, porém, àquela nova figura de filósofo que é representada pelos membros do Conselho Noturno.

No final da sua análise, Robin afasta-se nitidamente do projeto político platônico no seu conjunto e, por esta distância, partilha a posição da maior parte dos leitores europeus alheios ao âmbito alemão. Esse projeto mostra-se "vão" e falimentar: "os acontecimentos parecem ter tirado toda a possibilidade de sobrevivência ao aspecto político, precisamente aquele sob o qual Platão teria escolhido sobreviver" (p. 229). E, todavia, o "sonho platônico" não ficou sem ecos, mesmo se indiretos. Robin menciona a este propósito, como é habitual, a organização teocrática da Idade Média cristã (onde um poder espiritual rege a força militar e a sociedade dos laicos); mas acrescenta, como Gomperz, o projeto de reforma social de Auguste Comte. Aqui aparecia novamente a figura dos Sábios como mestres de educação nacional, a exigência de unidade social e, sobretudo, o afastamento relativo à "democracia integral e de tudo o que se parece com a livre expressão de uma iniciativa individual. Cada conceção política análoga não pode não fazer apelo ao sonho de Platão", conclui Robin (p. 230). O apelo ao positivismo comtiano é certamente, da sua parte, um sinal de recusa, típico do pensamento cristão-liberal, dos conte- 
údos constritivos próprios do pensamento político de Platão, tal como de todo estadismo organicista, apesar da sua simpatia pelos aspectos mais propriamente filosóficos deste pensamento.

\section{CATÓLICOS E LIBERAIS NA ITÁLIA FASCISTA}

A Itália da época fascista não tinha necessidade, ao contrário da Alemanha pós-bélica e nazi, de reivindicar uma suposta afinidade com os gregos, nem de procurar no seu pensamento, e no de Platão, fontes de legitimação e modelos inspiradores. Continuidade, legitimação e modelos eram facilmente oferecidos, para um país latino, pela política e pela cultura da romanidade imperial, da qual se devia, porventura, reivindicar a originalidade e a supremacia relativamente aos gregos (e, por conseguinte, à Alemanha helenófila): tarefa, esta, em que se viram ativamente empenhados os latinistas e romanistas italianos. Os traços com os quais Mussolini desenhava a sua ideologia na alínea Fascismo da Enciclopédia italiana (uma "criação espiritual" oposta ao materialismo positivista e socialista, além da liberal-democracia, segundo a qual o estado constituía a "realidade verdadeira do indivíduo") eram semelhantes, como se viu, a muitos lugares comuns da “ideologia alemã", mas não se fundavam em nenhuma referência que fosse além da cultura do século XIX; em outras obras, o mesmo Mussolini recorria de boa vontade aos precedentes romanos da vocação imperial da Itália. Para dar um exemplo, o mesmo estudioso 
filonazi Julius Evola, nos seus escritos racistas dos anos quarenta, evitava quaisquer apelos à eugenia platônica, tão apreciada por Günther.

Protegidos pelo privilégio da romanidade, os estudiosos italianos de Platão podiam ocupar-se dele num lugar tranquilo de neutralidade ideológica. É prova disso o fato que a alínea Platão da mesma Enciclopédia italiana (1935) fora atribuído a um filósofo liberal e antifascista como Guido Calogero, que no ano anterior, ao fazer a recensão de Paideia, se perguntara ironicamente: "temos que ler nas entrelinhas o desejo que o dritte $\mathrm{Hu}$ manismus se identifique com o dritte Reich?”.

Calogero atribui à política um papel bastante marginal no seu tratamento da obra platônica. Reconhece, contudo, como "sonho central" o "domínio ético-político das forças da razão sobre as forças da vontade". Deste "sonho" dependem, segundo Calogero, as "durezas dogmáticas do Estado platônico" que consistem, essencialmente, num governo legitimado só pelo saber, "sem nenhum respeito pela liberdade individual dos que não sabem". Sobre o tema da subordinação do indivíduo ao estado, Calogero parece seguir Hegel, atribuindo também a Platão uma recusa da propriedade e da família, por parte do indivíduo em geral e não só por parte da classe dos governantes. Mais aliada às tendências novecentistas é, pelo contrário, a reconstrução da biografia política de Platão, baseada, como é habitual, na Carta VII. Na República, Platão mostrava-se ainda "confiante em poder converter a ideia em realidade". O velho Platão das Leis, desiludido pela experiência siciliana, seria mais realista (mas 
as Leis representariam ainda assim um eventual plano constitucional para as cidades sicilianas). Por outra razão, e de maneira mais original, Calogero entrevê nas Leis um passo adiante na direção de um governo rígido desenhado pela República e pelo Político. Em vez de deixar, como acontecia nestes diálogos, amplo espaço à iniciativa autônoma dos filósofos no governo, as Leis esgotam uma vez por todas também a atividade legislativa. Assim, em vez de preparar o trono aos futuros filósofos, o velho Platão, fazendo-se legislador, ocupa ele próprio o trono.

A obra-prima dos estudos platônicos na Itália dos anos trinta é seguramente representada pelos dois volumes de Luigi Stefanini, Platão (1932-35): um estudioso paduano de orientação católica, alheio ao fascismo e sempre atento a distanciar-se cautelosamente da contemporânea literatura nazi sobre Platão (I, p. 364 nota).

Stefanini partilha, porém, com o espírito do tempo, a acentuada politização do pensamento do filósofo. O seu programa consiste numa "regeneração moral do indivíduo”, que só pode acontecer no quadro de uma polis por sua vez regenerada, não fora ou contra ela. Aliás, Stefanini, tal como Hildebrandt, tende a ler os diálogos tendo presente a biografia política de Platão. $\mathrm{Na}$ República deve ser vista tanto a "amargura do primeiro insucesso" seguida à primeira viagem à Sicília, quanto a esperança depositada no jovem Dionísio e em Díon. Trata-se, portanto, não "do exercício retórico de um pedante ocioso", mas de um "programa de ação do homem que, na longa vigília do estudo e da meditação, se tinha preparado para uma intervenção 
positiva no campo de batalha" (I, p. 338: ainda como Hildebrandt, Stefanini vê no Fedro 252e uma referência autobiográfica à ligação com Díon, p. 348 nota).

Considerando a sua interpretação, a leitura da República proposta por Stefanini ganha um sabor kantiano. Certamente o que se quer é melhorar a realidade existente, não transcendê-la, mas o ideal não é suscetível de ser perfeitamente reproduzido na história: ele pode, porém, orientar um "progresso infinito para o bem”. Todavia, aqui Stefanini identifica, com razão, uma tensão no pensamento platônico ou, pelo menos, uma dificuldade na sua interpretação kantiana. Não se chega ao nível do valor na temporalidade histórica, ou melhor, "ascende-se de uma só vez com um voo prodigioso" (I, pp. 349-50); para Platão, o tempo da história não é o do progresso, mas o da decadência. É difícil pensar num percurso de progressiva aproximação do ideal, dado o caráter instantâneo de seu eventual alcance, que representa uma ruptura, uma solução de continuidade no percurso histórico, como parecem indicar os livros VIII e IX da República.

Seja como for, Stefanini - tal como Pöhlmann considera infundadas quer a crítica a Platão, de matriz hegeliana, segundo a qual Platão sacrificou o indivíduo ao estado, quer a crítica zelleriana, segundo a qual Platão prospetou uma coerção não liberal do estado sobre os indivíduos. A unidade política coexiste, ou melhor, coincide, com a realização das qualidades e das atitudes dos indivíduos na sua diversidade. A razão estabelece para todos o direito à igualdade de responsabilidade para com a comunidade e de obediência à 
ordem coletiva; a autoridade do estado não é senão o reflexo da autoridade da razão em cada cidadão, defende Stefanini ao referir-se à célebre passagem da República IX 590-91. Por esta via, "a aristocracia coincide com a democracia" (I, p. 355). Portanto, a aristocracia platônica não apresenta de maneira nenhuma um caráter de casta, mas funda-se na razão; o seu poder encontra o limite e a norma na responsabilidade para a justiça comum, numa sociedade que deve ser, como escreve Platão, de "livres e amigos". A educação é chamada a formar um consenso espontâneo à ordem social, tornando marginal o eventual papel da constrição (I, p. 358).

Nesta ótica, a Stefanini o comunismo platônico parece estar em nítida oposição com o "comunismo materialista dos nossos dias"; se neste último domina "a avareza de todos", no primeiro, pelo contrário, é decisiva a magnânima renúncia aos interesses privados do indivíduo em nome dos da comunidade (o otimismo platônico consiste aqui, segundo Stefanini, em pensar numa generosidade generalizável, que na moral cristã pertence só a pessoas excecionais) (I, p. 359). A vários séculos de Platão, conclui Stefanini, e "depois de tantos experimentos liberais, continua a ser verdade que não se deve tirar autoridade ao Estado e subordinar os seus interesses aos dos indivíduos e aos dos grupos que o compõem” (I, p. 360).

Mas há também em Platão contradições, ou "dissonâncias", que Stefanini detecta lucidamente.

A primeira atravessa a figura do filósofo, dividida entre a imagem autárquica do Fédon (e do Teeteto) e 
a imagem erótica do Banquete; na mesma República, ou pelo menos, no livro VII, o filósofo parece não ter necessidade do estado, é renitente em voltar para a caverna. Não se reconhece nele "aquele fervor de ação e proselitismo que levara Platão a fundar uma escola e a tentar um governo perigoso" (I, p. 357).

A segunda "dissonância" consiste na dificuldade em obter o consenso da massa dos cidadãos que não podem ignorar os princípios supremos sobre os quais se funda a nova sociedade, e que não se sentem vinculados à comunidade política nem pela tradição, negada, nem por uma inexistente estrutura religiosa, nem pela nacionalidade pátria. Nesta situação, o poder arrisca-se a parecer "arbitrário e despótico", e a tripartição funcional arrisca-se a transformar-se em "esquálida uniformidade de tarefas e de trabalho". O católico Stefanini, ao contrário dos nacional-socialistas, não pode, naturalmente, aceitar a eugenia platônica, que lhe parece constituir uma "falsa aplicação da razão de Estado", nem sequer o feminismo, que, ao negar as diferenças de gênero, pode parecer "ofensivo para a feminilidade" nos valores e nas tarefas que lhes são próprios (I, pp. 361-3).

Por fim, Stefanini considera perigosa a recusa da lei, que Platão formula já na República e mais especificamente no Político, em nome de uma ciência ideal que corre o risco de mascarar o arbítrio dos governantes (I, pp. 360-1). A nostalgia do absolutismo, que caracteriza o Político e é confirmada pelo menos por uma passagem das Leis (IX 875), espelharia as esperanças resíduas que Platão depunha num sucesso final de Díon em Siracusa 
(II, p. 446). Mas nesta nostalgia Stefanini lê algo mais, algo mais universal e também atual, isto é, "a ânsia e o sofrimento da humanidade" que

\begin{abstract}
procura um Homem que a salve [um "Dux iluminado"], abandona-se a ele e abençoa-o, depois perde-o ou é traída por ele e, então, reforça as instituições representativas e estende as participaçôes populares no poder para compensar com o número o vigor do único que falta, consolida as próprias experiências segundo as leis e depois busca ainda a Vontade única capaz de dar uma alma às leis e uma forma às massas (II, p. 441).
\end{abstract}

Mesmo o estilo, tenso e atormentado, desta página, mostra como Stefanini vive de perto o drama do Político entre governo autocrático e governo das leis e das maiorias, e reconhece o pathos da sua época.

Como é habitual, as Leis são lidas como o sinal do fracasso de Díon, da dificuldade ou impossibilidade de encontrar um "déspota iluminado e perseverante", portanto, como documento de um maior realismo político de Platão. Neste diálogo, não se recusa o horizonte da idealidade, mas aceitam-se recusas e compromissos face à dureza dos fatos. As Leis são, pois, uma República imersa na história: a propriedade privada não é abolida, mas regulamentada, o arbítrio do sábio é limitado pela autoridade da lei. Uma "nova política medíocre", em suma, revivida pelos "homens políticos de todas as épocas", que se contentam com "modestas conquistas graduais”, conscientes, porém - e aqui 
pode-se ouvir um eco do progressismo de Pöhlmann de inspiração kantiana -, de que "aquilo que se quer deve ir mais além do que aquilo que se faz, para que o esforço seja sustentado e eficaz" (II, pp. 431 segs.). Isto vale também para o destino do comunismo platônico: um "comunismo realizado, na prática, com o regime da propriedade controlada e limitada: a dialética do pensamento platônico tem o mesmo resultado de certos experimentos comunistas, em geral, dos quais somos testemunhas nos nossos dias" (II, p. 448: talvez Stefanini pensasse na Nova política econômica de Lenine; de qualquer forma, a sua tentativa é uma das primeiras aproximações significativas de Platão ao caso da União Soviética, destinada, como se verá, a ter uma grande repercussão).

Mas há "dissonâncias" também nas Leis. Quanto mais elas se aproximam da realidade histórica, tanto mais refletem a separação entre uma aristocracia privilegiada e a "massa dos submetidos, escravos, mercadores, mercenários [isto é, trabalhadores assalariados], artesãos", uma "massa que desaparece, totalmente ignorada, vivendo à margem da vida grega, resultado da última política platônica” (II, pp. 449 seg.). A oposição entre República e Leis seria emblematicamente representada, no Timeu e no Crítias, por aquela oposição entre a antiga Atenas e a Atlântida: a primeira "é a cidade da ditadura divina e do comunismo, face ao reino da legalidade e da propriedade privada", o "primeiro estado" face ao medíocre "segundo modelo" de constituição (II, pp. 434 seg.).

As últimas palavras do livro, segundo as quais a solução desta tensão platônica "teria aparecido sob a 
luz de Roma" (II, p. 459), que, na verdade, parecem um pouco incongruentes, representam, talvez, a única homenagem explícita de Stefanini à ideologia dominante na Itália fascista.

De um teor completamente diferente é o livro de 1940 de Marino Gentile sobre a Política de Platão: uma tentativa verdadeiramente modesta de conciliar Platão com um fascismo temperado pelo catolicismo (exatamente nesta óptica, também Gentile se distancia dos intérpretes nazis, entre os quais insere, com surpresa, Hans Kelsen, p. 2 nota). Tal como Diès (e como a maior parte dos estudiosos deste período), Gentile está certo de que a atividade intelectual de Platão começou por interessar-se primeiro pelos ideais políticos. Para ele, testemunhas da politicidade imanente da filosofia, Ideia e Estado estavam inseparavelmente ligados e, por conseguinte, sentiu um "objetivo tenaz e constante de participar ativamente na vida pública e no governo do Estado" (p. 8, cf. p. 209). A Academia foi concebida como "viveiro de uma nova classe dirigente", ainda hoje modelo da "escola universitária como oficina de preparação política” (p. 11). Daqui parte o interesse atual de Platão por uma renovação da ciência política à luz dos valores do espírito, depois da crise das concepçôes políticas "prevalentes até à Revolução fascista" (p. 9).

Deste ponto de vista, Gentile considera a República o texto em que Platão teria refutado, ante litteram, o contratualismo moderno de Hobbes, Locke e Rousseau, estabelecendo a fundamental socialidade do indivíduo e, por conseguinte, a prioridade da sociedade e estado em detrimento dos indivíduos; o estado não nasce de 
um contrato, mas da "integração natural, orgânica e necessária do indivíduo”, por exigências éticas, além das econômicas e militares. Definição clássica que Gentile considera essencial nas "asperezas dos tempos em que vivemos" (pp. 43 segs., 52). Se o limite de Platão consistiu nos seus preconceitos contra o valor do trabalho e da pessoa, que só o cristianismo teria resgatado, ao invés, a sua grandeza está, por um lado, na distinção entre "produtores e soldados" (com este termo Gentile traduz sempre em linguagem fascista o termo platônico phylakes), que antecipa o estado corporativo, e, sobretudo, por outro, em ter subordinado a economia à política, ou seja, a um "Partido" (scil. fascista), "capaz de compreender, por condição e preparação, os fins gerais da atividade social” (pp. 54 seg.).

Parece significativa a atenuação que Gentile faz do pedido platônico de um governo de filósofos (agora considerados "soldados"). O filósofo não é o cultor específico de uma disciplina (aqui Gentile parece realmente esquecer o livro VII da República), mas um intelectual capaz de "dirigir-se exclusivamente à consideração dos problemas capitais para a vida moral e política”. A República constitui, assim, o "primeiro manifesto da intelectualidade na política”, que encontraria a sua realização na modernidade - realmente modesta, ao que parece - com o pedido do "certificado de habilitaçôes" para quem desempenha funçôes públicas (pp. 66 segs.). Da mesma forma, o aspecto melhor do comunismo platônico encontraria o seu cumprimento na figura do funcionário estatal, ao qual se pede que se afaste dos negócios privados (p. 88). De resto, até 
à República, Platão teria contemplado apenas "uma só ideia", a ideia do homem e do estado. E mesmo depois, apesar dos desenvolvimentos dialéticos, "prefere a simplicidade de um soldado às ziguezagueantes sutilezas de um sofista" (pp. 95 seg.), escreve Gentile em tom francamente mussoliniano.

As críticas que Gentile dirige às ideias expostas no livro $\mathrm{V}$ da República parecem estar mais inspiradas na moral católica, críticas que constituem, segundo Gentile, as expressōes mais utópicas e paradoxais do pensamento platônico e, ao mesmo tempo, vinculadas às contingências históricas. A abolição da propriedade privada e da família é incompatível com a condição essencial do homem, e aqui Platão fracassa precisamente como filósofo. A política demográfica, em vez de "expandir-se alegremente com a perspectiva de aumentar a população de modo indefinido", pretende limitar artificialmente o crescimento. No conjunto, as normas platônicas sobre a reprodução, apesar de não se estenderem até ao "amor livre", ao dissolverem a unidade viva da família, acabam por dar lugar, segundo Gentile, a uma "mistura, no final, repugnante, de carnalidade brutalmente natural com religiosidade miticamente artificiosa" (pp. 71-84).

Além destes marginais desvios, Gentile entrevê, contra Zeller, uma continuidade positiva - sinal da destinação ética do estado - entre República, Político (que prepara a revalorização da legislação positiva) e Leis (a este diálogo Gentile dedica, de modo bastante original, um amplo tratamento, que insiste na oportuna recuperação da família privada). No plano 
histórico, passado o sonho de um jovem tirano, o objetivo de Platão é, por um lado, "preparar a educação das gerações jovens numa ordem melhor e nova", por outro, propor uma concreta plataforma legislativa aos experimentos "acadêmicos" que decorrem em Siracusa e em Axos (p. 155).

Marginal, mas interessante, é a leitura que Gentile oferece do livro VIII da República, encontrando elementos de uma filosofia da história (como mais tarde faria Vögelin). Assim, corresponde à timocracia, em ambiente romano, primeiro o patriciado, depois o déspota iluminado e a burocracia imperial; à oligarquia, na Idade Média, correspondem as Artes maiores, no século XIX o estado burguês-plutocrático; à democracia corresponde o anarquismo moderno. Mais incerta é a questão da tirania, que vai encontrando os seus equivalentes na senhoria renascentista, no absolutismo subversivo contemporâneo, mas talvez também na "ordem nova» como resposta ao anarquismo democrático (pp. 109 segs.).

Em conclusão: a vitalidade do pensamento político platônico consiste, segundo Gentile, na supremacia do estado que submete a dimensão econômica da sociedade às próprias finalidades éticas; um estado unitário e forte que destina cuidados particulares à seleção da classe dirigente. As suas fraquezas são, por um lado, a ausência de capacidades expansivas, de "imperialidade", por outro, a "caridade cristâ" nas relaçôes sociais (pp. 207 segs.). Para uma e para a outra, evidentemente, era preciso aguardar pela Itália imperial e concordatária. 


\section{EM TERRA LIBERAL-DEMOCRATA}

Um traço saliente da receção do Platão político na cultura inglesa entre as duas guerras é constituído pela forte influência das tendências interpretativas alemãs contemporâneas (embora, muitas vezes, com o sinal avaliativo inverso e, como veremos, com uma integração importante).

Já Benjamin Jowett e Ernest Barker, entre os séculos XIX e XX, tinham visto em Platão um projeto educativo adequado à juventude e à classe dirigente britânica e um defensor dos direitos e da liberdade do indivíduo. Nos anos trinta, Richard Livingstone, em Oxford, e Lowes Dickinson, em Cambridge, seguem claramente os passos do Terceiro humanismo alemão. Dickinson em After Two Thousand Years, de 1930, imagina um diálogo entre Platão e um jovem inglês onde, aprovando-se a crítica do filósofo aos abusos da democracia de massa, se apresentava "a República e os seus ideais como a única solução real disponível para os problemas da humanidade moderna": palavras que Jaeger e os seus amigos teriam subscrito de boa vontade.

Mais difusa, e decerto mais incisiva, era a receção da imagem "reacionária" de Platão - elaborada na Alemanha e aceita na Inglaterra -, que se tornou, obviamente, motivo de reprovação do filósofo, dando lugar a repetidas e decisivas intervenções tendentes ao "desmascaramento" de Platão contra a sua tradicional imagem de peso e respeito. Tanto mais que, em relação à hermenêutica alemã, se acrescentava agora um elemento novo, compreensivelmente coberto pelos admiradores alemães do filósofo: o Platão "bolchevique". 
Platão aparecia bastante precocemente num panfleto de Bertrand Russell, de 1920, que pretendia esclarecer o público inglês sobre The Practice and Theory of Bolshevism. O paralelismo entre o regime bolchevique e a República é nele perfeitamente delineado, com palavras destinadas a obter uma eficácia duradoura:

O Partido Comunista corresponde aos guardiôes; os soldados têm mais ou menos o mesmo estatuto em ambos; na Rússia há uma tentativa de tratar a família mais ou menos como sugeria Platão [aqui Russell alude à política do "sexo libertado" de Alexandra Kollontai]. Suponho que se pode dar por certo que cada docente de Platão, em qualquer parte do mundo, deteste o Bolchevismo, e que cada Bolchevique considere Platão um antiquado bourgeois. Apesar disso, há um paralelismo extraordinariamente exato entre a República de Platão e o regime que os melhores Bolcheviques estão a tentar criar (p. 30).

Voltando a Platão, na sua História da filosofia ocidental (1946), Russell confirma a semelhança dos governantes platônicos com o partido comunista soviético, acrescentando-lhe os habituais paralelismos com os jesuítas do Paraguai e os eclesiásticos medievais (p. 161). A intenção de Platão era, segundo Russell, realista, não utópica, tendo Esparta e o governo do pitagórico Arquitas, em Tarento, como modelo; se tivesse tido sucesso, ter-se-ia obtido um estado dotado de víveres suficientes e hábil em batalha, mas, pela sua 
rigidez, fechado a qualquer progresso das artes e das ciências (p. 169). O principal erro teórico de Platão consiste, segundo Russell, em ter acreditado na objetividade dos valores éticos (cuja projeção política representa inevitavelmente um governo autoritário). Pelo contrário, Platão não teria entendido a importância do relativismo ético de Trasímaco (p. 172): crítica que pode parecer realmente estranha visto que foi o próprio Platão a ter formulado e argumentado esta teoria nos primeiros dois livros da República. Ainda em 1950, Russell voltava a insistir sobre o fato que as tendências reacionárias de Platão tinham escapado aos liberals, "até os seus discípulos Lenine e Hitler terem fornecido uma exegese prática delas".

O cara-a-cara de Platão com Arnold Joseph Toynbee - no terceiro volume do seu importantíssimo A Study of History, de 1935 - é mais forte. Toynbee pensa poder reconhecer um projeto político comum aos grandes teóricos do século IV, Platão e Aristóteles, que pretendia estabilizar e normalizar a sociedade grega durante a sua crise. Substancialmente, este projeto contemplaria uma aliança entre a casta militar espartana (na tradição de Licurgo) e a intelligencjia ateniense, que forneceria uma "casta intelectual soberana" (pp. 92 seg.). Esta casta seria formada, defende Toynbee retomando uma metáfora típica da República, por "cães de guarda humanos", que se reproduzem acasalando-se precisamente como os cães, e estão destinados à infelicidade, dado que se dedicam unicamente ao bem-estar coletivo do Commonwealth. O comunismo platônico representa "um grande salto para o desconhecido" em rela- 
ção ao rudimentar coletivismo da Esparta de Licurgo. Porém, o comunismo é logicamente necessário se "as células humanas do Leviatã têm de ser subordinadas ao pseudo-organismo social" (p. 95): aqui Toynbee refere-se indubitavelmente ao desenho que ilustra a capa da obra-prima de Hobbes, e formula um apelo que pretende, como veremos, impressionar o próprio Popper.

Os guardiōes de Platão, que reproduzem no nível intelectualmente mais elevado o grupo dos "iguais" spartiatoi, antecipam, por outro lado, segundo Toynbee, a casa real do Sultão otomano (p. 94, nota 33). Um paralelismo que se mostra bastante obscuro, visto que são muito mais claras as analogias encontradas entre a condenação platônica dos poetas - com a censura do "pensamento perigoso" - e as "regras obscurantistas da Rússia comunista, Alemanha nacional-socialista, Itália fascista, Japão militarista” (p. 97): desenha-se aqui o inteiro alinhamento dos espectros que a utopia de Platão (na verdade, um Platão lido precisamente pela ótica preferida dos adversários e, por conseguinte, facilmente predisposto à condenação) evocava para a cultura inglesa dos anos trinta.

No mesmo ano do volume de Toynbee aparece um ensaio importante de Francis Macdonald Cornford, Plato's Commonwealth (note-se que ao traduzir politeia os autores ingleses seguem o exemplo de Grote). A Grécia do século IV, tal como a Europa depois da Primeira Guerra Mundial, tinha perdido a confiança na capacidade da democracia garantir a ordem social. Por isso, era muito comum o "desejo de uma ditadura política 
ou espiritual" (pp. 48 seg.), capaz de guiar os homens a objetivos que eles não podiam escolher sozinhos; o desejo, pois, de uma autoridade que libertasse os homens do peso da liberdade. Desta forma, Xenofonte teria desenhado, na figura de Ciro, o retrato de um monarca paternalista, Isócrates ter-se-ia dirigido a Filipe de Macedônia, e Platão teria depositado as suas esperanças em Dionísio II e em Díon (naturalmente, Cornford considera a Carta VII autêntica).

Ao delinear o desenvolvimento político de Platão, Cornford repete curiosamente o esquema proposto por Hildebrandt: o Górgias marca a recusa de Platão em deixar-se envolver na política da Atenas democrática, mas não a recusa à exigência de unir filosofia e poder, fato que teria dado lugar quer às tentativas siracusanas, quer à fundação da Academia (uma escola para philosophic statesmen) (pp. 56 segs.). Ao contrário de Sócrates (e depois dos Estóicos), Platão não persegue a reforma moral do indivíduo, mas a construção de uma ordem social que assuma a natureza humana tal como é e procure retirar o que nela há de melhor; assim, a divisão das funções sociais busca ter em conta os desejos específicos de cada grupo, mas só se eles se harmonizarem na ordem comum. Isto requer, porém, o poder absoluto de um grupo capaz de impor ao corpo social os valores da comunidade. Neste sentido, Cornford concorda com a aproximação entre Platão e o bolchevismo proposta por Russell: "a sociedade pode ser reformada somente submetendo a massa da humanidade ao domínio indiscutível de uma pequena minoria, que está na posse da verdade e é capaz de uma devoção religiosa à própria tarefa” (p. 65). 
Todavia, mais que ao bolchevismo, segundo indicação de Wilamowitz, Platão deve ser posto ao lado da hierarquia da Igreja católica medieval, com a sua autoridade infalível. Este traço teocrático acentuase, segundo Cornford, nas Leis, com a instituição do Conselho Noturno que pode ser assimilado à Inquisição. Citando Dostoevskij, Cornford imagina o quadro sombrio de um Platão na pele do Grande Inquisidor que processa Sócrates, réu de livre pensamento (p. 67).

Este Platão teocrático e inimigo da liberdade de pensamento estaria no centro da polêmica antiplatônica dos estudiosos ingleses de teor marxista (agora o arqui-inimigo de Platão torna-se, porém, em vez do "democrático" Protágoras, o "materialista" Demócrito). Segundo Benjamin Farrington, para citar o principal dentre eles, toda a filosofia de Platão é uma filosofia política, e no centro se encontra a imposição de uma "verdade de Estado", garantida, por sua vez, pela teologia. A sociedade dividida em classes e a obediência total à vontade da classe dirigente são imposiçōes divinas, segundo as mais ou menos nobres mentiras propagandistas inculcadas pelos governantes para evitar revoltas populares (pp. 79 segs.). Nas Leis, com o Conselho noturno (comparado inevitavelmente ao tribunal da Inquisição) entra "pela primeira vez na história europeia a apologia da perseguição religiosa” (p. 92).

No âmbito da operação de "desmascaramento de Platão", tão comum na cultura inglesa entre as duas guerras, o contributo mais brilhante e de maior sucesso veio, porém, do inteligente panfleto de Richard Crossman, Plato Today, de 1937. Nas palavras do 
autor, o livro encontrou a aprovação de personagens eminentes como Bertrand Russell e Isaiah Berlin; Popper leu-o certamente com interesse, mesmo considerandoo demasiado indulgente em relação ao filósofo. Crossman era um bom conhecedor de Platão, embora não fosse um estudioso de profissão (no pós-guerra tornarse-ia deputado trabalhista).

No prefácio à edição pós-bélica do livro, Crossman refere-se ao escândalo suscitado no seu ambiente de Oxford pela descrição da Academia como uma school for counter-revolutionaries, e da República como um handbook for aspiring dictators. Há, talvez, alguns exageros, porque, como se viu, o "desmascaramento" de Platão já estava bem avançado, mas o de Grossman é certamente o primeiro trabalho sistematicamente voltado para esta operação, e também o mais largamente difundido.

A primeira parte do livro oferece uma reconstrução histórica do contexto social e das intenções de Platão. Ele encontra-se perante uma crise social em que estouram os conflitos de classe entre o povo e a oligarquia. Face a esta situação, a sua atitude não é de maneira nenhuma idealística, mas sim realista. Platão nutre uma estima pessimista pelas capacidades intelectuais e morais das massas e, por conseguinte, não acredita nas possibilidades de sucesso do regime democrático. É preciso uma ditadura, mas não opressiva como a do modelo espartano. A República deve ser considerada o manifesto programático da Academia como protagonista de uma benevolent dictatorship, de um governo imparcial capaz de superar os conflitos entre as classes (p. 77). Há duas possibilidades: ou a Academia se tor- 
na diretamente "não só a consciência mas o ditador político da sociedade grega”, ou então (como sugere a experiência siciliana), ela funciona como o "central advisory bureau para uma rede internacional de ditaduras aristocráticas"; em ambos os casos Platão desempenharia o papel de commander-in-chief (pp. 81 seg.).

No final do livro, Crossman pergunta-se porque Platão faliu. No seu conjunto, a sua política foi "demasiado ideal" (no sentido da divinização da elite) e "demasiado pouco ideal" (no sentido de negação de possibilidade de autorrealização das massas). Produziu-se assim uma "apologia racional da reação", mas, segundo Crossman, a "ditadura do Bloco de Direita virtuoso" só pode transformar-se numa polite form of Fascism. A posição platônica produziu, portanto, uma justificação para os déspotas militares (o "cesarismo" já atribuído a Platão por muitos intérpretes), para os príncipes do Renascimento (basta pensar no interesse pela República no ambiente da senhoria dos Visconti), para os ditadores modernos. Mas ela, afirma Crossman retomando uma tese muito comum, encontrou a sua realização histórica na Igreja católica, onde os eclesiásticos tomaram o lugar dos filósofos-reis (pp. 167 seg.). Contudo a nossa época, conclui Crossman, tem necessidade do espírito crítico, do respeito pela dignidade humana próprios de Sócrates, não de Platão.

Entre a primeira e a última parte do livro, Crossman imagina - e trata-se certamente das suas páginas mais brilhantes - um Platão hoje, que profere as suas avaliações sobre a Rússia soviética e sobre a Alemanha nazi. Em relação ao comunismo, Platão teria provado 
repugnância pela glorificação dos trabalhadores e das massas populares, sobretudo pelo materialismo do regime que punha como seu fim o melhoramento das condições econômicas da vida (portanto, um triunfo da epithymia, do instinto aquisitivo, que por este aspecto teria aproximado, a seu ver, a Rússia da América) (pp. 129 segs.).

No plano político, pelo contrário, Platão teria sentido um "interesse apaixonado" pela Rússia empenhada numa "tentativa consciente de planificar a sociedade humana de acordo com uma clara filosofia de vida". Ele teria certamente reconhecido nos dirigentes soviéticos os herdeiros dos seus filósofos-reis, embora seguidores de uma filosofia errada, e teria admirado a organização do partido comunista pela sua coragem, disciplina, obediência aos chefes.

Crossman vai mais além: na comum dedicação à "tirania do ideal”, ele reconhece uma profunda semelhança entre o "temperamento" de Platão e o de Lenine, pela inhumanity de ambos. Mas Platão teria sentido simpatia também por Stallin, apreciando sobretudo a capacidade de manter o controle do povo mediante o uso experiente de "nobres mentiras". No conjunto, Platão teria aprovado no comunismo exatamente os aspectos mais repugnantes para o pensamento democrático: o sacrifício das vidas individuais em vista da realização do "grande plano" coletivo, a supressão das oposiçóes, a convicção de que o filósofo-rei sabe exatamente o que a vida deveria ser, e considera as concepçóes opostas "superstições de beatos" (pp. 134 segs.).

Muito menos favorável é a atitude que Crossman atribui a Platão relativamente ao nazismo. 
Escrevendo a Aristóteles o resumo de uma visita sua a Berlim, Platão contar-lhe-ia que escutou o discurso de um político de aspecto "hitita", apreciando a sua habilidade demagógica em manter unido o povo, graças ao uso sem preconceito de "nobres mentiras" de tipo racista. Esperaria mais do orador seguinte, um filósofo autor de uma obra intitulada Platão e a conceção nacional-socialista do Estado (nesta figura Crossman concentra provavelmente autores como Rosenberg, Bannes e Hildebrandt). Este discurso suscita a indignação de Platão (que o considera pior do que o opúsculo do jovem Dionísio), porque reduz o modelo da República ao modelo espartano, e Esparta às origens raciais arianas. Esquecem-se assim as críticas de Platão ao regime militarista espartano e sobretudo revela-se a figura de um filósofo não senhor mas servo do demagogo. Em conclusão, Platão caracteriza o fascismo como um regime misto de timocracia e oligarquia: um juízo no fundo benévolo, porque evita a condenação do governo "hitita" como tirania (pp. 144 segs.).

Aqui encerra Crossman. Como se vê, graças a ele, e a muitos outros autores, a cultura inglesa dos anos trinta (recebendo e invertendo a interpretação platônica em voga na Alemanha contemporânea) tinha preparado grande parte dos materiais polêmicos de que se teria alimentado Popper, mesmo no quadro de pilares filosóficos mais robustos. 


\section{E OS BOLCHEVIQUES?}

Bertrand Russell, embora notasse as afinidades entre a utopia platónica e os projetos dos "bolcheviques melhores", tinha, todavia, suposto que eles teriam odiado o antigo filósofo "burguês". Mas não é bem assim. Platão chegava à Rússia, no limiar da revolução, através de Pöhlmann e de Natorp (além de Kautski), que o tinham apresentado como um genuíno precursor do comunismo: de fato, em 1923, Novitskii dedicaria um livro a Platão, na série "Antepassados do comunismo utópico". Mas no fervor dos primeiros anos da revolução - segundo o resumo de Frances Nethercott - são sobretudo dois os aspectos do Platão político que tocam o grupo dirigente bolchevique. $\mathrm{O}$ primeiro reside na ideia de "pedagogia social", ideia abraçada pelos estudiosos alemães, e no projeto de educação coletiva das crianças, com o objetivo de moldar o "homem novo": encontram-se ecos deste platonismo educativo quer no Código da família, de 1918, quer no livro Platão educador de Rubinstein, de 1920. O segundo aspecto diz respeito à "questão feminina", no sentido de um afrouxamento dos vínculos conjugais e de uma sexualidade livre, temas abraçados tanto por Clara Zetkin, quanto por Alexandra Kollontai.

Mas estes interesses estão destinados a esmorecer mal se fecha a fase da utopia revolucionária e o seu "comunismo de guerra", primeiro com o advento da Nova política econômica de Lenine, depois com o poder estaliniano (embora o jovem Stallin fosse um bom conhecedor de Platão). Há um regresso aos valores insti- 
tucionais da família e à ortodoxia marxista-leninista: os juízos peremptórios de Marx, sobre a República como idealização ateniense do estado de castas egípcio, e de Lenine (em Materialismo e empiriocriticismo, de 1909) sobre Platão como chefe da "linha idealista" em filosofia, voltam agora a exercer todo o seu peso.

Em 1923, as obras de Platão, junto com as de Kant, Nietzsche e outros, são excluídas da livre consulta nas bibliotecas soviéticas. Mesmo que reagisse à contemporânea propaganda nazi filoplatônica, o seu pensamento político era agora etiquetado como utopia reacionária, classista e anticientífica. Segundo Salomon Luria, um importante estudioso de filosofia antiga, Platão foi o precursor da cristandade medieval, do jesuitismo, da Santa Aliança, mas certamente não do "socialismo científico".

Talvez uma discreta e prudente reabilitação tenha sido realizada em época estalinista avançada. Pode-se encontrar vestígios na alínea sobre Platão na Grande Enciclopédia soviética escrita por um grande estudioso como Aleksei Losev. Nela oferece-se um quadro breve mas preciso e equilibrado da estrutura social delineada no Gosudarstvo (República). No final, à maneira de avaliação conclusiva, reproduz-se o juízo de Marx, sem acrescentar nenhum comentário. $\mathrm{Na}$ conclusão da alínea, a importância filosófica de Platão é identificada na sua fundação do "idealismo objetivo"; a isso segue-se a citação ritual de Lenine sobre a "linha platônica”. Tanta prudência é explicável se se levar em conta que Losev foi condenado a dez anos de trabalhos forçados, dos anos trinta aos quarenta, porque era 
suspeito de simpatias idealistas, voltando, em seguida, ao seu ensinamento na Universidade de Moscovo.

A alínea sobre Platão da numismática Ljudmila Kazamanova na Enciclopédia histórica soviètica é historicamente mais articulada. Platão teria procurado uma saída para as contradiçóes sociais da polis quer com o projeto parcialmente comunista da República, quer com o de um "estado agrário" nas Leis, em que pretende recuperar a condição da Ática antes de Sólon e da Esparta de Licurgo. A autora não recorre às habituais citações de Marx e de Lenine. A sua avaliação crítica é mais de teor hegeliano: em ambos os casos, Platão não teria conseguido superar os limites históricos e sociais da polis antiga.

As vicissitudes da interpretação sucessivas a 1921 justificam, portanto, a previsão de Russell; mas não escondem completamente a atenção e o favor com os quais a utopia platônica é acolhida nos primeiros anos da revolução, como premissa para a uma radical transformação educativa e moral da sociedade.

\section{NOTA BIBLIOGRÁFICA}

Os autores franceses citados são A. DIÈS, Introduction a Platon, La République, par E. Chambry, Les Belles Lettres: Paris (1932) 1989; L. ROBIN, Platone (1935, 19682), tradução italiana, Milano: Cisalpino, 1988.

Para os autores italianos: G. CALOGERO, Platone, in Enciclopedia italiana (1929-1936), Roma: Istituto della 
Enciclopedia Italiana, pp. 510-21 da edição de 1949; a recensão a Paideia encontra-se em "Giornale critico della filosofia italiana”, 4-5 (1934), pp. 358-71; L. STEFANINI, Platone, 2 vols. (1932, 1935), 19492 (reedição facsimilada Istituto di Filosofia-Istituto di Storia della Filosofia, Padova, 1991); M. GENTILE, La politica di Platone, Padova: CEDAM, 1940.

Sobre o ambiente cultural de língua inglesa, além do ensaio de Glucker citado no CAP. 3, $c f$. M. LANE, Plato's Progeny. How Socrates and Plato Still Captivate the Modern Mind, London: Duckworth, 2001 (pp. 97-134).

As obras citadas são respetivamente: B. RUSSELL, The Practice and Theory of Bolshevism, London: Allen \& Unwin, 1920; ID., Storia della filosofia occidentale, vol. I (1946), tradução italiana, Milano: Longanesi, 1966; ID., Philosophy and Politics, in Id., Unpopular Essays, London: Allen \& Unwin, 1950, pp. 9-34; A. J. TOYNBEE, A Study of History, vol. III, Oxford-London: Oxford University Press (19352), 1951; F. M. CORNFORD, Plato's Commonwealth (1935), in Id., The Unwritten Philosophy and Other Essays, Cambridge: Cambridge University Press (1950) 1967, pp. 47-67; B. FARRINGTON, Scienza e politica nel mondo antico (1946), tradução italiana, Milano: Feltrinelli 1960; R. H. S. CROSSMAN, Plato Today (1937, 19592), London: Allen \& Unwin, 1963.

Para o "Platão bolchevique", $c f$. F. NETHERCOTT, Russia's Plato. Plato and the Platonic Tradition in Russian Education. Science and Ideology (1840-1930), Aldershot: Ashgate 2000 (caps. 4-5). Pude consultar a alínea Platão na Grande enciclopedia sovietica e na Enciclopedia storica sovietica (nas edições de 1976) graças à ajuda de Adele Mazzotti. 
(Página deixada propositadamente em branco) 
6.

\section{HISTORICISMO E ENGENHARIA SOCIAL: O PLATÃO DE POPPER}

POR QUÊ PLATÃO?

uando foi obrigado a emigrar para a Nova Zelândia devido à iminente ameaça nazi, o filósofo austríaco Karl Popper já tinha publicado a sua grande obra epistemológica A lógica da descoberta cientifica. A urgência em escrever um grande livro de história e crítica da filosofia política, como The Open Society and Its Enemies, foi-lhe imposta pelo dramático caso da história europeia, de que ele era testemunha e vítima simultaneamente: ele próprio conta que o livro foi iniciado em março de 1938, no dia em que lhe chegou a notícia da invasão alemã da Áustria. A obra foi publicada em 1944, portanto, em plena Segunda Guerra Mundial. Para Popper tratava-se - no fogo da "luta perene contra o totalitarismo" (I, p. 15) - do combate entre as democracias ocidentais contra o fascismo e o nazismo, nesse 
momento, mas também, além destes, contra o estalinismo soviético (de fato, na Introdução de 1959, Popper afirma que se tivesse reescrito o livro, tê-lo-ia centrado na crítica ao marxismo), para chegar às origens da tragédia europeia, para compreender as suas raízes teóricas e intelectuais. É a autoridade dos grandes homens que justifica os maiores erros contra a liberdade e a razão. Não é de surpreender, portanto, que o segundo volume da obra seja dedicado à crítica dos profetas destes totalitarismos: Hegel e Marx. Mas todo o primeiro volume, The Spell of Plato, constitui um texto requisitório contra Platão, considerado o verdadeiro iniciador da genealogia de todos os totalitarismos.

De certa forma, esta também não é uma verdadeira surpresa. Como vimos, não faltavam, decerto, na cultura anglo-saxã numerosos precedentes desta crítica, aos quais Popper podia ir beber para construir a sua imagem de um Platão totalitário, predecessor tanto do fascismo quanto do bolchevismo. Ele refere-se explicitamente a Grote, Gomperz, Toynbee (notas 32 e 43 do cap. IV), Crossman (nota 2 do cap. VI). Mas é evidente que, na sua leitura de Platão, Popper também utiliza largamente as interpretações dos seus adversários "totalitários", a partir do próprio Hegel. Neste sentido, constitui um caso interessante o mesmo par conceitual sociedade aberta/sociedade fechada, onde o primeiro termo indica o espaço da autodeterminação individual livre, do pensamento crítico, e o segundo, pelo contrário, aponta para o imobilismo da tradição que vincula os indivíduos a desempenhar papéis pré-determinados, para o autoritarismo paternalista, 
para o organicismo coletivista, para a hostilidade à mudança. Popper declara que fez derivar os conceitos de sociedade fechada e aberta de Bergson, embora tivesse modificado o seu sentido (I, p. 284). Mas nesses mesmos anos, numa conferência feita em Nova Iorque em 1941, Leo Strauss usaria o mesmo par conceitual bem próximo da utilização de Popper, referindo a preferência da "sociedade fechada" pelo niilismo alemão, e a preferência da "sociedade aberta" pelo niilismo anglo-saxão de marca liberal. Do ponto de vista da sua teologia política, Strauss não partilhava nenhuma das posições, mas detectava, com clareza, o terrenos das escolhas e das oposições em que o próprio Popper conscientemente viria a estabelecer-se.

Numa frente ou noutra, fora largamente preparada a estrada para fazer de Platão o pai da genealogia totalitária. Contudo, Popper enfrentava o seu rival com uma profundidade de análises, uma potência de instrumentos teóricos e também uma energia refutatória que não tinham precedentes autênticos e que fazem do livro, quer o avaliemos pelos seus conteúdos quer pelos seus efeitos, um marco de época na história das interpretações modernas do Platão político.

\section{DIAGNÓSTICOS E TERAPIAS}

Como grande sociólogo que era, segundo Popper, Platão tinha compreendido perfeitamente os motivos do mal-estar social, da infelicidade da sua época. Os motivos consistiam na revolução que levou à ruína da 
sociedade tradicional, com a sua tranquilizadora fixidez de valores, costumes, funções, e com a proteção que a coletividade garantia às vidas de cada indivíduo. No seu lugar, nascera uma sociedade democrática e individualista, que fazia pesar ao indivíduo a responsabilidade pessoal, a insegurança, uma liberdade vivida como solidão e precariedade (é interessante notar que estas teses de Popper seriam retomadas por Eric Dodds no último capítulo da sua grande obra de 1951, The Greeks and the Irrational). Em vez da solidariedade comunitária surgiram os conflitos econômicos e de classe, o expansionismo, a ideia de um progresso com perspectivas incertas. Face a esta crise, a que Popper define a "grande geração" - a geração de Péricles, Heródoto, Protágoras, Antístenes, o mesmo Sócrates reagia com o exercício da razão crítica, com a aceitação dos riscos, da liberdade como a única garantia de um desenvolvimento autônomo da personalidade, enfim, com a concepção da política como confronto aberto sobre os valores e os projetos comuns (pp. 241 segs.).

Platão, como outros intelectuais atenienses à maneira de Crítias, reage, ao invés, contra a crise, interpretando-a como uma queda do homem de uma condição originária de felicidade, e propõe uma terapia regressiva, que se torna, segundo Popper, pior do que o mal que pretendia curar, traindo, assim, Sócrates (aqui é inevitável a comparação do Conselho noturno das Leis com o Tribunal da Inquisição, que teria processado Sócrates, réu de pensamento livre), em nome do pressuposto que "a justiça é desigualdade" (pp. 271 segs.). 
A partir deste quadro histórico, Popper desenvolve a sua tese requisitória contra Platão através de duas acusações principais: a do "historicismo" e a da "engenharia social utópica”. É o caso de as analisar separadamente, dado o diverso valor hermenêutico, e porque a primeira acusação parece mais fraca e até mais um pretexto, enquanto que a segunda é, sem dúvida, mais pertinente e mais rica de perspectivas problemáticas.

\section{PLATÃO E O HISTORICISMO REGRESSIVO}

O historicismo é, segundo Popper, a posição de quem: 1. pensa possuir um conhecimento certo das "leis da história"; 2. afirma que essas leis determinam necessariamente o rumo do mundo; 3 . considera o rumo do mundo um desenvolvimento e um progresso finalisticamente orientados. A acusação de historicismo a Platão serve evidentemente para fundar a sua aproximação aos outros réus do mesmo delito, Hegel e Marx (além de expô-lo à crítica que Popper desenvolveria de forma mais ampla na sua Miséria do historicismo, de 1957). Mas, para ser minimamente credível, no caso de Platão, a acusação deve deixar cair os pontos 2 e 3 e limitar-se a discutir as consequências do primeiro ponto.

Ao contrário dos historicistas "integrais", Platão defende que existe uma lei da mudança histórica, mas está convencido - como se vê no livro VIII da República - de que cada mudança signifique decadência e degeneração. Além disso, ele está convencido de que 
um esforço "sobre-humano" da vontade possa parar o processo de decadência, inverter o rumo da história de modo a orientá-lo para um regresso à primitiva "idade do ouro", à perfeição passada, da qual teve início a "queda" do homem (pp. 42 segs.).

Dois pontos devem ser salientados. O primeiro: Popper não vê o caráter evidentemente irônico dos mitos sobre a idade áurea de Crono no Político e no livro III das Leis, com a sua animalização da humanidade; além disso, passa por cima do fato que a primitiva "cidade saudável" do livro II da República é rapidamente liquidada, pela sua condição pré-política e pré-filosófica, como uma "cidade de porcos". O segundo: embora efetivamente no livro VIII do mesmo diálogo se ponha a hipótese da existência de uma kallipolis no início da história, a linguagem dos livros V e VI põe claramente a construção da mesma kallipolis num futuro não ciclicamente regressivo. Basta notar as formas verbais no futuro, por exemplo, em VI 499d1 (epeita genesetai), 501e4 (telos lepsetai) e em outras passagens.

Seja como for, Popper está convencido de que a intenção de Platão era curar a doença social do seu tempo, fazendo voltar para trás o relógio da história, isto é, remontando - mesmo antes das apreciadas culturas de Esparta e Creta - até às "antigas formas tribais de vida social” (p. 76), representadas precisamente no mito de Crono. Canceladas as lutas de classe e o mal-estar da liberdade, aqui os homens vivem na segurança oferecida por um rei pastoral e patriarcal, pelo domínio de uma casta militar que acode o "rebanho humano", num coletivismo tribal que atribui para sempre os papéis e 
as funções de cada indivíduo (pp. 77 segs., 152 segs.). Neste quadro, o rei-filósofo (com o qual Platão se identifica) parece mais um "rei-sacerdote tribal”, uma espécie de feiticeiro ou xamã (pp. 209, 216).

Esta é, grosso modo, a terapia proposta por Platão para a crise da sua época. De fato, escreve Popper, indo mais além de Hegel, que para Platão "o indivíduo é o Sumo Mal em sentido absoluto", e o critério moral consiste apenas no interesse do estado (na verdade, conceito incongruente para uma sociedade tribal, mas, como veremos, não se trata da única oscilação popperiana) (pp. 152 segs.). Para argumentar esta tese, Popper realça duas passagens das Leis, nas quais a subordinação do indivíduo à comunidade (para não dizer, ao estado) é expressa de maneira deveras eloquente. A primeira é a famosa passagem do livro $\mathrm{V}$, onde Platão, ao referir-se à República, afirma que a melhor cidade é aquela em que,

com quaisquer meios o que é dito privado, por quaisquer modos é retirado de todas as partes da vida, e procura-se, o máximo possível, tornar, em certo sentido, comum também o que por natureza é do indivíduo, por exemplo, os olhos, as orelhas e as mãos, para que pareçam ver, ouvir e agir em comum (739c).

A segunda passagem, muito menos citada, pertence ao livro XII e refere-se especificamente às atividades militares, mas pode ser facilmente estendida a toda a vida social: 
Jamais ninguém, homem ou mulher, sem um comandante [anarchon], nem a alma de alguém, a sério ou a brincar, por hábito se acostume a agir sozinha e por iniciativa própria, mas viva em todas as situações de guerra e de paz, virando sempre o olhar para o comandante e o siga, deixando-se guiar por ele mesmo nas coisas mais pequenas [...] e, numa palavra, ensine a alma, através dos hábitos, a não conhecer nem a saber iniciar uma ação separadamente dos outros; que a vida de todos seja o máximo possível coletiva e comum a todos [...]. A anarquia deve ser eliminada da vida inteira de todos os homens e animais sujeitos aos homens (942c-d).

Há, como se vê, muito para justificar pelo menos algumas das asserções de Popper. Ao contrário, por outros aspectos, ele - talvez influenciado pelas suas fontes, talvez impelido pela agitação polêmica - opera alguns desvios teóricos incorretos em relação às suas próprias teses, que ganham o aspecto de uma série incontrolável de asserções retóricas.

A primeira delas (sugerido talvez por Toynbee e Crossman) consiste em assimilar o "holismo" tribal ao organicismo do Leviatã de Hobbes, que pertence evidentemente à esfera do estado moderno (pp. 118 segs.); à mesma esfera pertencem figuras do "totalitarismo" como a polícia secreta (p. 278). O mesmo efeito retórico transforma o "xamã" tribal em formas de poder relativamente modernas, como a tirania e o despotismo. De resto, o mesmo Popper insere entre os 
méritos do Platão "sociólogo" o de ter formulado uma teoria das elites que anteciparia Pareto (p. 67), e da qual é difícil ver a relação com a regressão ao primitivismo tribal. Outros ingredientes, como se vê, misturados um pouco desordenadamente na maior 'sopa' de "totalitarismo" de todos os tempos.

A segunda asserção sofre, pelo contrário, a influência dos leitores nacional-socialistas de Platão. Fala-se, então, de uma "raça dominadora" (dórica) que submete uma população sedentária, tendo como referência o fim do livro III da República (pp. 82 seg.); de um "mito do Sangue e da Terra" exprimido pela "nobre mentira" (p. 199); por fim, do rei-filósofo como se fosse um "criador científico da raça dominante" (pp. 211 seg.), fazendo do texto platônico "historicismo biológico" (p. 120), com um tom que lembra de perto mais a interpretação de Günther, que o próprio "tribalismo" popperiano.

Por último, a terceira asserção consiste numa reutilização da linguagem própria da crítica marxista a Platão. Assim, o patriarcado tribal (cuja vantagem era, noutros textos, considerada uma espécie de regresso a uma sociedade sem classes) é agora considerado como "o governo natural de classe dos poucos sábios sobre os muitos ignorantes" (p. 129), com a sua propaganda que, na esteira de Farrington, visa impedir qualquer inovação cultural. Mais especificamente, a doutrina hierárquica da justiça própria de Platão significa fazer consistir a própria justiça num "privilégio de classe", num "governo de classe", opostos ao igualitarismo grego que constitui "o arqui-inimigo" do filósofo (pp. 134 segs.). 
Do tribalismo arcaico ao despotismo estatal moderno, ao domínio de raça ou de classe: a panóplia do antiplatonismo é alinhada sem poupar forças com o custo inevitável de produzir um monte de argumentos pouco controlável histórica e teoreticamente.

\section{A ENGENHARIA SOCIAL UTÓPICA}

De maior densidade e de maior interesse é a segunda das acusaçóes de Popper. Ela pode ser lida independentemente da primeira, no sentido que os supostos conteúdos "tribalistas" são inessenciais em relação à estrutura do desenho utópico atribuído a Platão. Este desenho pode ser definido, antes de mais, por oposição aos seus dois grandes adversários: por um lado, Marx, que recusa qualquer forma de engenharia social em nome da legalidade imanente à história (mas Platão e Marx partilham, pelo contrário, o radicalismo das suas atitudes) (p. 230); por outro, a forma de engenharia social gradual, ou reformista (à letra, piece-meal), preferida por Popper, que trabalha não para o bem último, mas contra os males presentes (pp. 44, 221).

A estrutura da engenharia social utópica é claramente identificada por Popper. Em primeiro lugar, está a ordem dos fins: a teoria das ideias é o instrumento teórico que permite delinear e fundar o modelo de estado perfeito, por definição imutável e invariável (pp. 44, 48, 55).

Após este fato, o problema do engenheiro social utópico é projetar os meios adequados à obtenção da finalidade estabelecida. Trata-se de uma dedução de 
tipo condicional (se... então), que não tem nenhuma necessidade de consenso e, aliás, não pode admitir dissensões. Cada objeção parece insensata e reacionária. O que é preciso é um sistema de poder centralizado que garanta a realização sequencial da cadeia de meios com vista ao fim, ou seja, a ditadura de quem conhece o modelo a realizar e é capaz de derivar dele a planificação racional da sociedade inteira (pp. 221 segs.).

Em tudo isto há, nota sutilmente Popper, um componente significativo de estetismo: imperfeição do mundo tomado como modelo torna impaciente o engenheiro social utópico face à estratégia reformista que consiste na tentativa de "remendar" o existente. A política torna-se - neste quadro - uma arte cuja obraprima consiste precisamente na sociedade nova que o engenheiro social está construindo. A beleza perseguida torna-o completamente indiferente à violência porventura necessária durante a obra (Popper cita o dito de Lenine, segundo o qual "não se pode fazer uma omeleta, sem partir os ovos"). Platão fala de um pintor de constituições que tem de limpar a tela antes de começar a esboçar o seu quadro desta forma (Resp. VI 501a): pouco importa se esta limpeza implicar, por exemplo, a expulsão da cidade de todos os habitantes com mais de dez anos (VII 541a), ou então, como diz o Político, a sua "purga", matando ou exilando parte dos seus cidadãos (293d-e) (pp. 231 segs.).

Quais são, para Popper, os erros escondidos neste modo fascinante de pensar? Antes de tudo, há o inevitável dogmatismo sobre os fins. O fim último não pode senão ser o objeto de uma intuição que é im- 
possível argumentar racionalmente, razão pela qual é preciso recorrer à força para resolver as dissensóes. E, sobretudo, o modelo mostra-se não modificável, apesar da indefinida dimensão do tempo necessário para o realizar: cada mudança do modelo em realização tornaria inúteis e vãos os meios até àquele momento usados para a sua atuação. Por outro lado, falta e faltará sempre uma base de conhecimento empírico suficiente para prever os efeitos - numa perspectiva temporal assim tão vasta - das tentativas de planificação integral da sociedade, motivo pelo qual é impossível prever racionalmente os resultados do processo de transformação, que se funda, precisamente, só na admissão dogmática do fim último. (Poder-se-ia observar que Platão efetivamente modificou, entre a República e as Leis, a ordem das finalidades dos seus projetos de engenharia social. Mas Popper poderia replicar que Platão não pôde, entretanto, dar início ao programa da República: senão teria recorrido a exílios e genocídios, para depois tomar consciência que tudo isso era inútil em vista das diversas finalidades previstas nas Leis).

Em suma, conclui Popper: pela arbitrariedade dos fins e pela impossibilidade de controlar racionalmente a sequência dos meios, é muito provável que a engenharia social utópica, em vez de levar para o céu, traga para a terra o inferno (p. 235). Evidentemente voltaremos a esta lúcida agressão à utopia platônica. Mas antes de saudarmos Popper, é preciso dar conta do seu "retrato" eficaz de Platão. Quem era Platão?

No diagnóstico de Popper, a mente de Platão estava dividida por uma "luta titânica" entre o fascínio da sociedade aberta, encarnado por Sócrates, e, o apelo 
da tirania representado por Crítias: ou seja, entre "o mundo de um modesto, razoável individualista e o de um totalitário semideus" (pp. 189, 273 seg.). No final, prevalece a "vontade de poder" nietzschiana (p. 219). A partir disto, a biografia política de Platão pode ser lida através dos diálogos, à maneira de Hildebrandt. A República testemunha "vivazes e exaltantes esperanças de sucesso", às quais seguem períodos de depressão (p. 218); as Leis apontam para o par tirano/legislador que menciona a relação entre Dionísio II e Platão (p. 274). Porém, no final, nota sarcasticamente Popper, Platão, que esperava fundar o primeiro reino filosófico com a Academia, acaba por instituir nada mais nada menos que a primeira cátedra de filosofia (p. 219).

Mas o insucesso de Platão, conclui Popper, infelizmente foi apenas provisório. Com o tempo, o político totalitário acabaria por ter demasiado sucesso, a partir da Idade Média até à idade moderna (p. 240). E o potencial antidemocrático da sua "escrita venenosa", dado que é fascinante (tal como a do livro VIII da República), está ainda bem longe de se ter esgotado (pp. 71 segs.).

\section{DEPOIS DE POPPER}

Popper encontra imediatamente o consenso de personagens ilustres como Bertrand Russell, Ernst Gombrich e Gilbert Ryle que, numa positiva recensão de 1952, em "Mind", reafirmava as teses popperianas e escrevia secamente: "Berchtesgaden e o Kremlin mantêm as promessas da República e das Leis". 
Não faltou, como é natural, uma reação igual e imediata por parte dos especialistas da antiguidade, duplamente irritados pela invasão de terreno por parte de um incompetente e pela sua dessacralização de um clássico venerável como Platão. O livro 'picuinhas' de Levinson, In Defense of Plato (1953), constituía um minucioso elenco dos "erros" e das distorções interpretativas de Popper (o qual, na verdade, não tinha demasiada dificuldade em replicar no apêndice da edição de 1959). Num ensaio importante de 1967, Bambrough avisava estes críticos de Popper que a tentativa de defender Platão a este nível (isto é, tentando demonstrar com os instrumentos de uma suposta neutralidade filológica, que Platão não tinha verdadeiramente defendido todas as deploráveis consequências que derivavam das suas premissas teóricas) constituía uma estratégia unprofitable, demasiado fraca e intelectualmente destituída de interesse. Dado que o ataque versava precisamente sobre estas premissas, era necessário empenhar-se numa discussão sobre elas, associando o ponto de vista histórico com o filosófico.

O saudável aviso de Bambrough não encontrou muitas repercussões nem a curto, nem a longo prazo. Entre as raras tentativas de recolher a este nivel o desafio de Popper, pode-se citar um ensaio interessante de Maurer, de 1995, sobre a questão da relação entre a ideologia igualitária das democracias contemporâneas e o duradouro aparecimento de elites tecnocráticas e "meritocráticas", herdeiras, mais ou menos legítimas, da "aristocracia racional" preconizada por Platão (que, deste modo, se afasta, segundo Maurer, da alternativa 
totalitarismo/democracia que imperava na "ideologia ocidental"). E deve ser também lembrada a importante discussão de Schofield (2006) em torno da questão da utopia entre Popper e Platão, da qual voltaremos a falar.

Se são raros os casos de discussão histórico-filosófica sobre os princípios reguladores do pensamento político de Platão, desejada por Bambrough, pode-se tranquilamente dizer que faltou de todo uma análoga discussão sobre os princípios que orientam o discurso de Popper. Podemos apresentá-los em forma de dois esquemas silogísticos: 1. só o pensamento liberal-democrata é aceitável - mas Platão era organicista, holístico, comunitário, iliberal; logo, Platão estava errado e o seu pensamento é inaceitável; 2. só o reformismo gradual é aceitável - mas Platão era um engenheiro social utópico hostil ao reformismo -, logo Platão está errado e o seu pensamento é inaceitável. Esquematizado deste modo, não seria difícil considerar o pensamento de Popper passível de acusação de totalitarismo (definido assim segundo a fórmula de Bambrough: só há um guia acessível para os problemas morais e políticos; há um método unívoco para decidir quem tem razão e quem não em todas as discórdias sobre o bem e o mal). Seja como for, é certo que considerar indiscutíveis os princípios de Popper (como próprio de uma espécie de "pensamento único" intransmissível) produziu uma longuíssima série de "defesas de Platão" certamente menos ingênuas, mais intelectualmente sofisticadas que as que tentou fazer Levinson, mas, talvez por isso mesmo, ainda mais arriscadas no plano hermenêutico. 
Creio que o efeito devastador produzido pela crítica de Popper não consistiu em ter delineado uma imagem de Platão como um pensador não redutível à tradição de pensamento liberal-democrata (porventura cristão), e como autor de um projeto utópico fundado numa teoria dos valores ético-políticos considerados objetivos e não discutíveis. $\mathrm{O}$ efeito devastador está, pelo contrário, em ter produzido, durante toda a segunda metade do século XX, uma impressionante sequência de esforços tendentes à refutação desta imagem, com a consequência, já temida por Bambrough, de "desfigurar" ou deformar Platão como os seus críticos e mais do que eles.

De tudo isto se falará nos capítulos seguintes, mas já se podem encontrar as linhas principais destes esforços que, com a intenção de defender Platão de Popper, muitas vezes acabaram por tentar defender Platão de si mesmo. A primeira, minoritária mas que recentemente está avançando, constituiu na defesa de Platão ser um pensador de alguma forma liberal-democrata; a segunda, mais refinada, elaborou a tese de que Platão não defendeu verdadeiramente as teses que Popper lhe atribuiu, em todos os sentidos que se podem atribuir ao advérbio verdadeiramente.

Portanto, é com a marca de Popper que se desenrolará a história hermenêutica do Platão político na segunda metade do século XX, e isto constitui uma prova indiscutível da força intelectual da sua agressão crítica. 
NOTA BIBLIOGRÁFICA

A obra de K. R. POPPER, The Open Society and Its Enemies, vol. 1: The Spell of Plato (1944), London: Routledge \& Keagan Paul, 19665, é citada na tradução italiana La società aperta e i suoi nemici, Roma: Armando, 1973.

Para L. STRAUSS, cf. Il nichilismo tedesco (conferência pronunciada por Strauss em, 1941 na New School for Social Research de Nova Iorque), tradução italiana in Nichilismo e politica, a cura di R. Esposito, C. Galli e V. Vitiello, RomaBari: Laterza, 2000. Para E. R. DODDS, $c f$. The Greeks and the Irrational, California: University of California Press, 1951, cap. VIII (The Fear of Freedom) (tradução italiana I Greci e l'irrazionale, Milano: Sansoni, 2003).

A recensão de G. RYLE e o ensaio de R. BAMBROUGH, Platos modern friends and enemies, estão incluídos na recolha de R. BAMBrough (ed.), Plato, Popper and politics, Cambridge: Heffer, 1967 (respetivamente pp. 85-90, 3-19).

Cf. também: R. B. LEVINSON, In Defense of Plato, Cambridge (MA): Harvard University Press, 1953; R. MAURER, De l'antiplatonisme politico-philosophique moderne, in Contre Platon, t. II: Le platonisme renversé, par M. Dixsaut, Paris: Vrin, 1995, pp. 129-54; D. FREDE, Platon, Popper und der historizismus, in E. Rudolph (Hrsg.), Polis und Kosmos, Darmstadt: Wissenschaftliche Buchgesellschaft, 1996 (pp. 74-107); M. SCHOFIELD, Plato. Political Philosophy, London: Oxford University Press, 2006 (cap. 5: Utopia). 
(Página deixada propositadamente em branco) 
7.

\section{DEFENDER PLATÃO DE POPPER \\ (OU DE SI MESMO?)}

a longa história das defesas de Platão do ataque
de Popper, que se estende por toda a segunda metade do século $\mathrm{XX}$, nenhum intérprete ocidental pôs em discussão a premissa maior do silogismo popperiano: que o pensamento liberal-democrata (e, em algumas variantes, cristão) fosse o único modo aceitável de conceber a política. Desejando salvar Platão da conclusão do silogismo (Platão estava errado), para evitar a sua expulsão da "boa" tradição ocidental, demasiado pesada de suportar, em virtude da sua duradoura auctoritas, era necessário, então, refutar a segunda premissa popperiana, segundo a qual Platão não era um pensador político liberal-democrata, mas um autoritário ou até totalitário.

As três linhas defensivas pensadas para realizar esta refutação podem ser esquematizadas deste modo: 
1. A primeira, e mais simples, consiste em sustentar que Platão era verdadeiramente, de alguma forma, um pensador político liberal-democrata e, por conseguinte, Popper estava errado.

2. A segunda, mais complexa e articulada, tem o seu ponto forte na tese segundo a qual - apesar do consenso de uma tradição exegética milenar que vai de Aristóteles ao próprio Popper - Platão verdadeiramente não defendia que as posições expressadas nos seus diálogos políticos fossem, na realidade, desejáveis e de certa forma realizáveis. Esta tese distingue-se em duas variantes: a) os textos políticos de Platão pertencem ao gênero literário da utopia e não apresentam nenhum aspecto projetual; b) os diálogos políticos de Platão têm uma intenção irônica, que consiste em defender o contrário do que aparece à superfície do texto. Num caso e no outro, Popper estava errado, porque a sua crítica ataca um falso alvo.

3. Não obstante as aparências e o consenso quase unânime da tradição exegética, os ditos diálogos políticos de Platão não pertencem absolutamente ao âmbito da filosofia política, pois visam exclusivamente os problemas da moral individual (a polis é, quando muito, uma metáfora da alma). Mesmo neste caso, acontece que Popper falhou o alvo, atribuindo a Platão intençôes diretamente políticas.

Neste capítulo falaremos da primeira e da segunda linhas; a terceira será discutida no capítulo seguinte. 


\section{PLATÃO LIBERAL-DEMOCRATA}

A corrente interpretativa que visa defender Platão das acusaçóes de Popper, mostrando que o seu pensamento político apresenta, de fato, elementos liberais, ou até democráticos, deu provas de uma surpreendente tenacidade durante toda a segunda metade do século XX no ambiente cultural anglo-saxão, partindo de Levinson até aos recentes estudos de Monoson, Saxonhouse e Bobonich. Surpreendente pelo menos por três razões: em primeiro lugar, porque estes intérpretes devem fazer um autêntico braço de ferro com as evidências textuais; depois, porque devem desafiar (ou simplesmente ignorar) uma tradição secular oposta, que vai de Hegel a Zeller, de Grote a Gomperz, de Russell a Toynbee e Crossman (para não falar das vicissitudes do século XX "continental”); por fim, porque devem enfrentar refutações de peso como, por exemplo, as recentes refutações de Jean-François Pradeau e Lucio Bertelli (que seria ingênuo considerar definitivas dado o forte peso ideológico que motiva esta tendência e também porque foram formuladas precisamente em ambiente "continental").

É o caso de considerar de perto, neste capítulo, sobretudo o ensaio de Charles Griswold, de 1995, que tem o título emblemático de Le libéralisme platonicien, porque apresenta a posição liberal-democrata com o mais rico e inteligente repertório argumentativo, constituindo assim, de certa forma, um cruzamento de todas as tendências antipopperianas.

Griswold parte de um resumo das críticas feitas à "provocação" platônica: trata-se de uma teoria não 
igualitária, hierárquica, dependente de uma metafísica que pressupõe uma inaceitável redução de todos os bens humanos sob um bem único e unívoco, além disso, de um projeto irrealizável e, por princípio, incapaz de alcançar os resultados desejados; em suma, de uma "teoria política não liberal, injusta, impraticável e sobre-determinada" (p. 162). A primeira linha defensiva parece francamente retórica: como é possível, pergunta-se Griswold, que um filósofo que "falou do amor de modo tão comovente", tenha acreditado que um regime totalitário e "espiritualmente degradante" (mas qual?, perguntamo-nos) seja capaz de fazer justiça à natureza humana? (ibid.).

Mas a estratégia de Griswold é, na realidade, mais articulada e vê-se nas passagens que podem ser resumidas da seguinte maneira:

1. Sócrates era, sem dúvida, um defensor da liberdade política, e a sua moral consistia numa concepção da perfeição individual como telos primordial do ser humano. Nisto Griswold apela-se implicitamente a uma longa tradição, de Mill ao próprio Popper, que contrapusera o "democrático" Sócrates, adepto do pensamento livre, ao autoritário Platão, mas, de modo mais explícito, apela-se aos estudos sobre a Apologia e sobre o Criton de Vlastos e Kraut, que retrataram um Sócrates "histórico" como adepto, embora crítico, do regime democrático ateniense.

2. Mas, no final, este Sócrates, individualista e democrático, é só uma personagem de Platão, e a moral que lhe é atribuída funda-se em princípios da metafísi- 
ca platônica; portanto, o Sócrates democrático, liberal e individualista não é senão a expressão do pensamento do seu autor, e não pode, de forma alguma, ser-lhe contraposto.

Aqui, Griswold reconhece que, nos textos políticos de Platão, e sobretudo no modelo "holístico", iliberal e anti-igualitário - pelo menos, aparentemente proposto pela República -, existem elementos de contradição relacionados com esta imagem que, todavia, ele não considera insuperáveis (pp. 165, 168 seg.). Para este objetivo, para o sucesso da operação, torna-se necessário eliminar da República a imagem geral de Platão ou, pelo menos, tirar a potência do seu peso contraditório.

3. A primeira tática usada neste sentido consiste numa peculiar aplicação do "princípio dialógico" que, porém, se refere só a este e não a outros textos platônicos mais aceitáveis. "Platão pode fazer afirmar às suas personagens todo o tipo de coisas, sem todavia esperar retomá-las como ideias próprias, nem persuadir o leitor a aceitá-las tais como são" (p. 170 seg.). A intenção de desplatonizar a República leva Griswold a notar que Aristóteles - que "escolhe cuidadosamente as palavras" na sua crítica à filosofia política de Platão no livro II da Política - atribui as teses da República a Sócrates e não a Platão (p. 175, nota 48: é necessário notar que, infelizmente, o "cuidadoso" Aristóteles atribui a Sócrates também as teses do Ateniense nas Leis).

4. Mas não basta, evidentemente, esta "aproximação dialógica" unidirecional ao objetivo de tornar irrelevante a República. O ponto central é que a sua kallipolis, hierárquica e holística, não pode existir. 
À primeira vista, nada de novo em relação à crítica aristotélica. Mas a novidade consiste no fato de, em Griswold, como em muitos dos "defensores" de Platão do ataque de Popper, a asserção desta impossibilidade não ser pronunciada contra Platão, mas atribuída ao próprio Platão.

A panóplia dos argumentos usados para demonstrar esta tese é, como veremos, muito vasta e sofisticada. Griswold limita-se, porém, a uma constatação geral, por um lado, e a uma referência de duas passagens específicas da República, por outro. A constatação é esta: os filósofos-reis da República seriam sophoi, possessores de uma sabedoria completa; mas sabemos de outros textos, como o Fedro e o Banquete (que Griswold faz aproximar do Politico), que estes filósofos não podem existir, dado que, por definição, o filósofo platônico ama e procura o saber, e não é seu depositário (p. 170). Pode-se observar, a este propósito, que embora a aquisição de um saber definitivo e a realização completa da kallipolis sejam para Platão provavelmente impossíveis, uma e outra podem, todavia, constituir a finalidade de um percurso que se aproxime dela "o máximo possível". Se assim é, a kallipolis permaneceria desejável, mesmo não realizável, para Platão, mas isto não o libertaria das acusações para simpatizar com o seu dito "holismo" hierárquico. De resto, no mesmo Banquete se afirma que o desejo de imortalidade para os homens de engenho se traduz na produção de obras duradouras; e "a forma de inteligência muito mais importante e bela é a que diz respeito à constituição da vida pública e privada, cujos 
nomes são temperança e justiça”. Disto são testemunhas os autores de "boas leis" para as cidades, como Licurgo e Sólon (208e segs.): pode-se, portanto, ser bons legisladores e governantes mesmo sem possuir a sabedoria completa.

Quanto às duas passagens chamadas em causa para testemunhar a impossibilidade (e também a não desejabilidade) da kallipolis segundo Platão, a primeira aparece no final do livro VII (540e seg.) e prevê, como ato inicial da refundação da cidade, a expulsão "para o campo" (eis agrous) de todos os habitantes com mais de dez anos, já demasiado comprometidos com os costumes tradicionais. Dado que esta passagem constitui um dos cavalos de batalha de todos os intérpretes que pretendem apresentar a cidade da República como impossível, e/ou indesejável, aos olhos do seu autor, é o caso de a discutir brevemente. Creio que a afirmação platônica não contém nada de tão absurdo que constitua um deliberado sinal de não desejabilidade. A locução eis agrous pode ser entendida como equivalente de eis georgous: isto significaria apenas a atribuição preliminar de todos os adultos à terceira classe (salvo, entenda-se, os governantes e os seus auxiliares que presidem à reforma), onde os camponeses representam precisamente a parte maioritária. Após esta partida inicial da estaca zero para a condição social, poderão começar os processos de seleção segundo as atitudes, de que o livro III fala amplamente. Todavia, mesmo que se queira ler a passagem à letra, ela não conteria nada de surpreendente. A expulsão de grande parte do demos da cidade e a ruralização da Ática fazia parte do 
programa concebido pelo radicalismo oligárquico de Crítias ( $c f$. Diels-Kranz 88A1); e em 385 os espartanos operaram uma análoga ruralização de Mantineia ( $c f$. Xenofonte, Helénicas V 2.5-7). Por mais que tudo isto possa parecer desagradável aos modernos paladares liberais, não há nada de particularmente perturbador para o pensamento político grego de orientação radical do IV século. De resto, formula-se uma análoga exigência de "purificar" (ou "purgar") o corpo cívico como premissa para a reforma da cidade quer em República VI 501a quer, até mais drasticamente, em Político 293d.

A segunda passagem mencionada por Griswold é a célebre passagem do final do livro IX da República (592a-b), onde a kallipolis é considerada um "paradigma no céu”, oferecido a quem pretenda fundar uma cidade justa na própria "interioridade” (p. 171). Trata-se, claramente, de uma interpretação e de uma tradução impróprias do texto, mas delas falaremos no próximo capítulo, porque a passagem é crucial sobretudo para os intérpretes que leem a República como obra não política e destinada à moralidade individual.

Vejamos, então, as conclusões importantes que Griswold retira da sua análise. Mesmo admitindo, pergunta-se, que a kallipolis "não seja igualitária nem liberal, Platão concebeu a República como um programa destinado a ser aplicado numa sociedade?". Em vista da sua declarada impossibilidade, a resposta é clara: o que Platão queria era mostrar que "mesmo um estado de fato pensado idealmente sofre de graves imperfeições" (p. 171). Uma conclusão que se apro- 
xima muito das teses de Strauss, de que se falará no parágrafo Platão irónico, e que, porém, não são explicitamente mencionadas.

A análise do Político consente a Griswold reforçar e desenvolver a sua linha interpretativa.

Neste diálogo o melhor regime é considerado o poder absoluto de um ou poucos homens detentores de um saber político configurado como "ciência régia"; este regime não terá necessidade de conformar-se a uma legislação rígida nem de obter o consenso dos súditos em vista do bem que ele procura. Platão está perfeitamente consciente de que o modus operandi desta forma absoluta de poder desemboca na tirania, quando é detido por homens desprovidos da "ciência régia» e das intençôes morais que lhes são implícitas, e, por isso, é considerado com suspeita e desconfiança pela maioria dos homens. Em ausência (provável) de homens dotados do supremo saber político, são, então, preferíveis regimes regidos por uma legislação constitucional rígida: o melhor deles é a monarquia, ao qual seguem a oligarquia e democracia (a democracia é, pelo contrário, o melhor dentre os regimes imperfeitos privados de lei, porque a fragmentação paritária do poder entre uma pluralidade de indivíduos o torna ineficaz, portanto, incapaz de causar grandes males, o que acontece quando ele está concentrado nas mãos de um tirano).

O Politico parece, assim, confirmar a convicção de Griswold: Platão estaria a expor a utopia da perfeição, o melhor regime pensável, para mostrar como ele também, além de irrealizável, não está isento de defeitos e de riscos. 
Daqui em diante, o centro da filosofia política de Platão se deslocaria para a procura do second-best, isto é, o melhor dos regimes praticáveis em vista da realização da perfeição individual, abandonando as tentações holísticas e hierárquicas (pp. 172 segs.). A cidade de segundo escalão constitui, portanto, o tema tanto do Político quanto das Leis, diálogos onde a ideia de que a melhor forma de regime realizável é sempre imperfeita teria como resultado "adoçar o funcionamento social" (p. 174). Do privilégio da "secunda cidade" Griswold passa decisivamente ao da democracia. No Político, o mito de Crono indicaria que no mundo desordenado em que vivemos, uma "democracia constitucional" constituiria "o regime apropriado à nossa era” (p. 180). Na verdade, como se viu, mais que um second-best, ela parece constituir um third-worst; e, como notou Rowe, é precisamente o seu respeito pela legislação considerada inviolável a poder motivar, segundo Platão, a condenação à morte de um reformador à maneira de Sócrates.

Mas Griswold encontra indícios de simpatias democráticas também na descrição do regime democrático do livro VIII da República, onde este regime aparece também como o quarto dos regimes "degenerados" e como a 'antecâmara' da tirania. Este regime de "liberdade de expressão" (parrhesia) teria permitido a crítica socrática (pp. 172, 190 segs.): contra isto se poderia objetar com a obviedade própria da democracia ateniense (satirizada aqui por Platão), que condenou Sócrates à morte por crimes ideológicos. Mas, sobretudo, nota Griswold, neste regime ninguém é obriga- 
do a governar e, por isso, este torna-se propício aos filósofos, cuja relutância em se envolver politicamente é defendida no livro VII do diálogo.

É o caso de determo-nos brevemente sobre este ponto, até porque a recusa dos filósofos a governar constitui um dos pontos salientes também das posições dos intérpretes straussianos, fiéis ao dogma de Strauss acerca da incompatibilidade entre política e filosofia.

É verdade que Platão prevê esta resistência. Mas é igualmente verdade que o legislador Platão sanciona, de modo categórico, a necessidade de impedir, no futuro, a separação entre modo de vida político e modo de vida filosófico (V 473d), e considera o empenho político dos filósofos uma obrigação da justiça, isto é, um dever moral imprescindível (VII 520d seg.).

$\mathrm{Na}$ esteira do Fedro, Griswold sustenta, pelo contrário, que a abertura para a comunidade pode superar os limites da busca da perfeição individual em virtude do amor pelos outros, que inclui o desejo de promover também a sua capacidade de perfeição, fora da dimensão hierárquica do governo político (pp. 184 segs.).

No início, observava-se que as teses de Griswold se situavam, de certa forma, num cruzamento das interpretações de Platão em sentido liberal-democrata. A montante, as interpretações pressupõem, pelo menos implicitamente, a defesa "irônica" de Platão levada a cabo por Strauss e pela sua escola. A jusante, elas teriam sido seguidas por uma série importante de pesquisas que desenvolveram as suas implicações.

Entre estas, devem ser mencionadas, em primeiro lugar, as valorizações dos "segundos regimes" platônicos, uma vez declarada irrealizável e/ou indesejável 
a inaceitável República. A relativa valorização dos regimes "legais", no Político, foi considerada então um prelúdio às Leis. E houve uma decisiva apreciação das mesmas Leis - sobretudo por obra de Bobonich - como projeto de uma "constituição mista" que contém elementos apreciáveis de caráter liberal e até democrático: prevalência dos instrumentos de persuasão (expressados, por exemplo, nos preâmbulos às leis) em relação aos de constrição; o caráter eletivo de algumas magistraturas (embora não das principais); o desaparecimento de uma classe de governo munida de um saber absoluto ou de uma "ciência régia"; por fim, e, talvez, sobretudo, o regresso à propriedade privada e à família. Tudo isto tornaria o regime das Leis certamente mais praticável relativamente ao da República (é, sem dúvida, esta a opinião do velho Platão) e, pelo menos segundo os intérpretes, também mais desejável do que ele, apesar da declaração explícita em Leis $\mathrm{V}$ 739, com base na qual o "primeiro regime" é mencionado só para mostrar a sua inconsistência.

Uma segunda tendência visa, mais corajosamente, valorizar os elementos "democráticos" presentes na mesma República: por exemplo, são prova disso os estudos recentes de Sarah Monoson e Arlene Saxonhouse. Em substância, os estudos tomam à letra as apreciaçôes platônicas da anarquia democrática no livro VIII, como a sua "docilidade", a sua tolerância para com a liberdade de expressão e de crítica, a possibilidade de exercer a filosofia por gosto e, sobretudo, como é natural, a igualdade concedida a todos. Como observaram muitos críticos, trata-se, todavia, de aspectos agradá- 
veis para um paladar democrático, mas que em Platão constituem mais uma espécie de paródia cômica da democracia ateniense, na sua inversão anárquica de cada hierarquia de valores e de mérito, na sua indiferença para com os fundamentos éticos e educativos da comunidade; uma comédia, entre outras coisas, que só pode abrir a via para a trágica tirania.

\section{PLATÃO UTÓPICO}

Hans Georg Gadamer dedicou a Platão uma série de escritos tanto vasta quanto conforme ao seu modo de pensar. A sua interpretação orienta-se por duas linhas principais: por um lado, a "ressocratização" de Platão, ou seja, a valorização do aspecto dialogal, intersubjetivo e problemático da sua pesquisa filosófica; por outro, a tentativa de reconciliar Platão com Aristóteles, mostrando a sua continuidade no âmbito quer metafísico (teoria das ideias, ideia do bom), quer ético.

Enfrentando, todavia, os escritos políticos de Platão (com a intenção usual de os defender da crítica popperiana), no ensaio Pensar por utopias, Gadamer não pode esconder que eles apresentam um "desafio poderoso", "uma grande provocação lançada à consciência moderna cristã e liberal do humanismo que venera Platão como um dos seus grandes heróis"; um desafio e uma provocação que produzem uma tensão intolerável entre as ideias políticas extremas que são afirmadas nos escritos platônicos, e a que Gadamer considera a anima naturaliter christiana de Platão (pp. 63 seg.). 
Segundo Gadamer, pode-se sair deste impasse só se se utilizarem os instrumentos da hermenêutica literária, que aconselham a "não tomar à letra" as teses do Platão político. Os seus grandes textos - aqui Gadamer não distingue a República das Leis - pertencem, de fato, a um preciso gênero literário, o da utopia, já bem conhecido na Grécia, como mostram, entre outros, Aristófanes e Eurípides (p. 70). Para retomar uma distinção feita por Finley, da qual voltaremos a falar no Cap. 9, não se trata de utopia de reconstrução mas de utopia de evasão, como os contos da idade do ouro, do país da felicidade, das ilhas beatas. A suposta "teoria política" de Platão é, na realidade, uma construção satírico-utópica, que representa uma "cidade nas nuvens" (p. 74); noutro texto, Platão e os poetas (1934), Gadamer escrevera: "Este Estado é um Estado mental e não terreno [...]. o Estado não pretende ser o projeto de uma ordem melhor da realidade da vida estatal" (p. 195). Retomando os termos de uma antiga polêmica, Gadamer parece estar mais perto da "Quimera" de Brucker do que do ideal regulador de Kant, para não falar da "realidade substancial" de Hegel.

Qual é, então, a função filosófica dos "mitos" narrados por Sócrates na República e nas Leis? "O pensamento por utopias", escreve Gadamer, não pretende oferecer o utópico como algo real ou realizável, mas arrastar para o incondicionado o diálogo da alma pensante consigo mesma, que nunca pode ser cumprido (p. 82). Trata-se, portanto, de "jogos racionais", onde se experimenta o "belo risco do pensar" (pp. 90 seg.), numa pesquisa aberta que não leva a nenhuma solução. É fácil ver como a leitura utópica de Gadamer 
esvazia a República e as Leis de qualquer conteúdo político positivo. O erro de Popper foi ver teorias e propostas (ou seja, de "levar a sério" Platão), onde se falava apenas de "mitos" e de "jogos".

Se algum conteúdo emerge da análise de Gadamer, trata-se da descoberta platônica da justiça no devir da polis, um "fingimento que permite compreender melhor a anima naturaliter christiana, dado que aqui se analisa a interioridade da alma e a justiça que a domina" (p. 83): uma consequência que, como veremos no próximo capítulo, dominaria a linha interpretativa que pretendia despolitizar Platão.

Não é o caso de discutir ulteriormente a questão da utopia neste momento, porque ela será retomada no Cap 9. Bastarão duas observações. Por um lado, Gadamer está naturalmente inclinado à consideração da Carta VII como inautêntica ou irrelevante. Por outro lado, ele é obrigado a ignorar numerosas passagens em que Platão nega o caráter de euché, "voto" ou "pio desejo", ao desenho da República, que tornaria ridículo (geloion) todo o discurso (V 450d, VI 499c, VII 540d). Mas trata-se de um preço "hermenêutico" que, ao que parece, é preciso pagar para responder a Popper e à "provocação" platônica.

\section{PLATÃO IRÔNICO}

O problema central da reflexão contínua que Leo Strauss dedicou à filosofia política consiste na relação entre teologia e política, nos limites da última face à 
transcendência da Lei revelada e na necessidade de ela ser orientada pela "ordem unitária e total da vida humana” prescrita pela própria Lei. Deste ponto de vista, Strauss envereda por uma incansável polêmica contra o pensamento político da modernidade, de Maquiavel e Hobbes até Hegel, visto como o fundador dos opostos ateísmos liberal e comunista, e também do niilismo de decisão à maneira de Schmitt. Escreve Strauss em Liberalismo antigo e moderno:

Comecei então a perguntar-me se a autodestruição da razão não era o resultado inevitável do racionalismo moderno, isto é, distinto do pré-moderno, especialmente do hebraico-medieval e das suas bases clássicas (aristotélicas e platônicas). Este estudo baseava-se numa premissa, sustentada por preconceitos poderosos, que dizia que um regresso à filosofia pré-moderna era impossível. A mudança de direção [...] obrigou-me a comprometer-me em muitos estudos, durante os quais prestei sempre maior atenção ao modo com o qual os pensadores heterodoxos do passado escreveram os seus livros (p. 321).

Strauss indica aqui, sobretudo, as suas importantes pesquisas sobre Maimónides, e menciona o duplo valor destas pesquisas. Por um lado, a reconstrução de uma tradiçãao (clássico-hebraica) que deve ser lançada contra as filosofias políticas da modernidade; por outro lado, a verificação (inicialmente, partindo dos textos de Maimónides) de um método hermenêutico 
peculiar, capaz, se for o caso, de unificar e "normalizar" esta tradição, nivelando contradiçôes aparentes, limando arestas concetuais, defendendo-a de eventuais fruições liberais, comunistas ou "niilistas".

Trata-se, substancialmente, do seguinte: os "pensadores heterodoxos" (como Maimónides e Platão, mas não Aristóteles) socorreram-se da escrita da dissimulação, de maneira a veicular (esotericamente) o sentido do seu pensamento aos que fossem capazes de o entender, evitando, ao mesmo tempo, o risco de cair na censura e na perseguição por parte da autoridade política que podia sentir-se ameaçada por aquele pensamento. Muitas vezes, a dissimulação toma a forma (decisiva, como veremos, na leitura straussiana de Platão) da ironia. Convém dizer já que, a este propósito, a hermenêutica straussiana da dissimulação e da ironia não só se aplica a autores medievais, mas também, pelo menos no caso de Platão, repete, talvez inconscientemente, uma característica da sua aproximação exegética.

Como se viu no Cap. 2, já Proclo notara uma reticência dialogal em certas passagens de Platão.

$\mathrm{E}$, face às suas teses mais embaraçosas, Bernardo de Chartres, Abelardo e Egídio Romano falaram de uma escrita per involucrum, in tegumentum, de um metaphorice loqui. Pier Candido Decembrio defendera claramente que aquelas teses deviam ser entendidas como exposiçôes ironice, sub enigmate.

De fato, Platão punha um problema historiográfico relevante a Strauss, que Myles Burnyeat delineou de forma muito eficaz. 
Ele lançou-se na difícil tarefa de mostrar que a República significa o contrário do que ela diz; que Aristóteles a leu como o faz Strauss e que concordou; e, por fim, que a conceção platónica das "coisas políticas" foi conservada, essencialmente, por toda a tradição da filosofia política clássica (sem excluir Aristófanes e Xenofonte) através dos Estóicos e por outros depois deles [...]. Mas se Platão fosse aquele utópico radical que os estudiosos normais creem que ele tenha sido, então não existiria algo como o conservadorismo unânime dos "clássicos"; nenhum desastre, como a perda da sabedoria antiga por obra de Maquiavel e Hobbes; ninguém como " $o$ filósofo" que ensine aos gentlemen a respeitar "os limites da política".

Strauss expõe o seu combate contra Platão - com grande mestria exegética - nos capítulos que lhe dedica em The City and Man, de 1964, e na quase contemporânea History of Political Philosophy.

As primeiras, cautas, táticas de Strauss para produzir um distanciamento da superfície textual dos diálogos das verdadeiras intençóes do autor consistem em regras metódicas de leitura, à primeira vista partilháveis, e até pioneiras no terreno da interpretação platônica.

Strauss formula, em primeiro lugar, aquilo que seria mais tarde definido como a "aproximação dialogal": ao contrário de Aristóteles, Platão, ausente dos diálogos, nunca propôs uma tese na primeira pessoa ( $C M$, p. 50). Nos diálogos há, é verdade, personagens dialógicas 
que podem ser consideradas "porta-vozes" do autor. A primeira delas é naturalmente Sócrates. Mas Sócrates foi sempre considerado um "mestre de ironia": ora, "a ironia é uma espécie de dissimulação, ou de untruthfulness" (p. 51): uma nobre dissimulação da própria sabedoria superior. O Sócrates protagonista dos diálogos lança, contudo, sobre eles a suspeita da dissimulação irônica acerca do seu autêntico significado.

Mas há outros "porta-vozes" de Platão, como o Estrangeiro eleático, Timeu, o Ateniense das Leis. A pluralidade destes porta-vozes, juntamente com a dissimulação irônica, induz a pensar que os diálogos pretendem significar coisas diferentes para pessoas diferentes: a verdade para os interlocutores ou leitores capazes de a entender, "opiniōes saudáveis", edificantes, para os outros (pp. 52 segs.). Ao princípio da ironia se deve acrescentar o do esoterismo: um texto filosófico construído com uma estratificação de significados, superficiais e profundos, é capaz de selecionar por si mesmo os seus fruidores, aquilo que, segundo o Fedro, o livro em forma de "manual" não pode fazer.

A terceira tática de Strauss consiste em aproximar o diálogo platônico - mas aqui já se começa a falar especificamente da República - da comédia de Aristófanes, em particular, das Ecclesiazuse. A aproximação é sugerida pelo "ridículo" constantemente evocado no diálogo, mas, sobretudo, por uma consideração densa de consequências. Cada diálogo, tomado individualmente, é inevitavelmente parcial, no sentido em que enfrenta o seu argumento fazendo abstração de outros aspectos teóricos relevantes para o próprio argumento. Esta ine- 
vitável abstração torna, porém, impossivel a solução do problema posto no diálogo; ora, defende Strauss, "o impossível [...] se for tratado como possível, é, em sentido mais forte, ridículo ou cômico” (p. 62), precisamente no sentido da comédia de Aristófanes.

O problema torna-se agora identificar de que é que a solução política do problema da justiça faz abstração, e que, por conseguinte, a torna impossível. Citamos, em primeiro lugar, os carateres fundamentais desta solução segundo Strauss: trata-se de um regime de "comunismo absoluto", governado por filósofos que garantem que cada energia psíquica seja dedicada ao interesse da comunidade, e asseguram, através da persuasão e da coerção, esta dedicação também por parte das classes subalternas. Algo, portanto, escreve Strauss - recuperando Marx, mas sem o citar -, que assemelha à "sociedade egípcia de castas" (p. 113). É verdade que, em linha de máxima, a pertença às diversas classes não é hereditária, mas ela tende a sê-lo (por exemplo, a assimilação dos filhos da terceira classe às classes superiores, por mérito, revela-se impossível porque eles conheceram os próprios pais).

Este projeto, segundo Strauss, em primeiro lugar, faz abstração do corpo. A dedicação total à comunidade pode dizer respeito só à mente: a corporeidade, com os seus desejos e, antes de tudo, com o eros que ela origina, está irredutivelmente privada dela, por isso, preme na direção oposta à da direção comunitária. A mesma igualdade de funções políticas entre homens e mulheres, essencial no desenho platônico, ignora a diferença corpórea e, ao fazer da reprodução uma tarefa exclusiva- 
mente política, "silencia as instâncias do eros". Por isso, a comunidade platónica é inatural (pp. 109-17).

Disto deriva imediatamente a impossibilidade da cidade platônica. Escreve Strauss, repetindo a crítica aristotélica por este motivo: "A igualdade dos sexos e o comunismo absoluto são contra a natureza" (p. 127); portanto, a "cidade justa" (onde Strauss reconhece a mais profunda expressão do idealismo político) é constitutivamente impossível (convém notar, desde já, que Strauss nunca atribui explicitamente a Platão a consciência desta impossibilidade, mas as suas conclusões, como veremos, não deixam dúvidas a propósito).

Uma segunda razão para a impossibilidade consiste numa contradição radical: os filósofos são necessários para a realização do projeto platônico (só eles são capazes de orientar totalmente o eros e o desejo para a comunidade); mas, como mostra o livro VII, os filósofos não querem governar, porque se dedicam à mais alta atividade concedida ao homem e desprezam as vicissitudes humanas que se desenrolam no mundo da "caverna". Os filósofos podem ser obrigados a governar só pela coerção da cidade, mas aqui se cria um círculo vicioso: os filósofos deveriam convencer a cidade a obrigá-los a governar contra a sua vontade. A separação entre filosofia e cidade confirma, pois, a impossibilidade estrutural da kallipolis platônica (pp. 124 seg.). De fato, ela torna-se indesejável quer para a maioria, que deveria sacrificar-lhe a corporeidade e o eros, quer para os próprios filósofos, que se veriam obrigados a renunciar à sua atividade teórica.

Neste ponto, Strauss está pronto a tirar as suas conclusões seja das premissas metódicas sobre a natu- 
reza irônico-dissimuladora do diálogo, seja da análise das contradições estruturais que o diálogo apresenta: "Sócrates esclarece na República que caráter é o que a cidade deveria ter para satisfazer as necessidades mais elevadas do homem. Fazendo-nos ver [itálico meu] que a cidade construída de acordo com esta exigência não é possível, permite-nos ver os limites essenciais, a natureza, da cidade" (p. 138). Portanto, Platão é consciente desta impossibilidade; o sentido do diálogo é refutar os aspetos "prometeicos" da engenharia política (para usar termos de Popper), esclarecer, através de um experimento intelectual que leve as suas ambiçóes ao limite, que a política não pode disputar o espaço que cabe à filosofia e, para além dela, à teologia.

Na History of Political Philosophy Strauss clarifica ulteriormente esta conclusão: "a República mostra tacitamente como a cidade efetiva - isto é, a cidade não comunista, que é construída pela associação dos pais mais do que pela dos artesãos - é a única cidade possível" (p. 161).

O capítulo platônico da History apresenta também mençôes ao Político e às Leis que confirmam o quadro interpretativo straussiano. O primeiro diálogo, levando aos limites extremos a figura de um poder absoluto baseado na ciência, e mostrando, assim, a sua impossibilidade, "mostra explicitamente a necessidade de um governo fundado nas leis” (p. 161). O limite insuperável das possibilidades da política leva Platão, nas Leis, a delinear a melhor estrutura política compatível com a natureza do homem, e, por esse motivo, possível e desejável. Portanto, conclui Strauss, "as Leis são a úni- 
ca obra propriamente política de Platão" (ibid.): uma tese que, como veremos no próximo capítulo, seria partilhada também por intérpretes "impolíticos" de Platão à maneira de Julia Annas.

Platão, comenta Strauss, não é um pensador liberaldemocrata, nem fascista, nem comunista na aceção marxista (HPP, p. 108). Mas a impossibilidade de transformar a "cidade existente" em "associação de pais", a não desejabilidade da perspectiva comunitária, a insensatez da convicção própria do idealismo político de que os males da humanidade possam ser curados com os instrumentos da política, fazem do Platão straussiano um filósofo mais próximo do liberalismo conservador do que de qualquer outra opção política.

A análise platônica de Strauss, convém dizer, avança sempre com cautela e sobriedade mesmo quando parece recorrer a pressupostos infundados e a uma leitura muito seletiva dos textos. Todavia, a imensa influência exercida por Strauss sobre uma grande parte da cultura americana fez com que ela se depositasse numa série de dogmas que dominariam a tradição straussiana. Eis os pontos fortes deste dogmatismo: 1. o caráter irônico-cômico, dissimulador, por conseguinte, a intenção autorrefutadora da República, cujo sentido profundo se mostra oposto às teses explicitamente argumentadas; 2. a impossibilidade e a não desejabilidade da kallipolis, por causa a) de ser contra natureza, dado que nega as instâncias da corporeidade e, em primeiro lugar, do eros; $b$ ) da irredutível oposição entre filosofia e política, cuja conciliação é, ao invés, o pressuposto necessário do projeto platônico; 3. os limites insu- 
peráveis da política e a sua constitutiva inferioridade em relação à filosofia. Os três dogmas naturalmente se entrecruzam e aparecem nos diferentes autores da tradição exegética straussiana. Isolaremos aqui, como exemplos para a discussão, alguns dos representantes mais significativos.

\section{IRONIA}

Brumbaugh (1989) afirma que toda a utopia da República é de natureza irônica, e que não há nenhuma justificativa para tomá-la à letra como $a$ doutrina política de Platão. Tratar-se-ia, quando muito, de uma concepção socrática, que Platão não partilhava, porque ignora as partes irracionais da alma (pp. 25, 36). O tradutor e intérprete hiper-straussiano da República, Allan Bloom (19912), vê na obra inteira um desafio cômico a Aristófanes, uma série de absurd considerations expostas com ar sério (pp. 381, 392). A reflexão de Hyland (1988) é muito mais articulada e parece o melhor contributo desta tradição exegética. A ironia representa o lado negativo da natureza humana, isto é, aquela sabedoria socrática que consiste na consciência da própria impossibilidade (p. 335): de resto, já Strauss havia considerado a teoria das ideias como utterly incredible, fantastic (CM, p. 119). Assim, tornase "irônica" a crítica à poesia, porque até os diálogos platônicos são "arte", enquanto imitação de um saber absoluto e homogêneo impossível. E irônico - por conseguinte, impossível e também indesejável - é o 
projeto da República, porque se funda na necessidade da "nobre mentira" com o fim de condicionar retoricamente os cidadãos (pp. 327-35).

Convém fazer algumas consideraçōes críticas acerca do dogma da ironia. A hermenêutica irônica (onde a "ironia" é entendida, aristotelicamente, como dissimulação que pretende significar o contrário do que se diz) funda-se, essencialmente, em dois pressupostos. $\mathrm{O}$ primeiro está no recurso que Platão faz do "porta-voz" Sócrates, universalmente considerado "mestre de ironia". Este pressuposto é evidentemente tão pouco fundado (porque Sócrates é uma personagem platônica e, por conseguinte, a sua natureza irônica seria um efeito, não uma causa, de uma decisão de autoridade que ficaria na mesma por explicar), como excessivo, porque seria desacreditar como irônica a maior parte dos diálogos platônicos e, além deles, de toda a tradição socrática. $\mathrm{O}$ segundo pressuposto consiste numa espécie de círculo vicioso. Selecionam-se afirmações platônicas (como a expulsão da nova cidade de todos os habitantes com mais de dez anos) que $a$ nós podem parecer tão absurdas que não seriam atribuídas seriamente a Platão, para concluir que se trata de sinais da sua intenção irônica, isto é, autorrefutadora. Tudo isto confirmaria o carácter de dissimulação do texto da República, cujo sentido oculto seria oposto ao sentido explícito.

Esta última tese é facilmente refutável. Porque é que Platão exporia apertis verbis toda uma série de teses escandalosas para a opinião pública (comunhão de mulheres e filhos, abolição da propriedade privada e da família, nudez e promiscuidade das mulheres nos 
ginásios, governo dos filósofos), e destinadas a irritar a autoridade política (basta pensar na violenta crítica do regime democrático ao poder desenvolvida no livro VIII), para, pelo contrário, transmitir esotericamente uma mensagem tranquilizadora e conformista, como o programa de uma democracia moderada à maneira de Aristóteles? Isto serve certamente para absolver Platão da crítica de Popper, mas parece verdadeiramente insustentável. Uma excelente crítica, deste mesmo teor, à suposta dissimulação platônica aparece, de resto, no importante livro de 2005 de um revisionista straussiano como Stanley Rosen, não por acaso dedicado to the genuine Leo Strauss (pp. 5, 10, 390), do qual teremos de voltar a tratar.

A questão da hermenêutica irônica é certamente de difícil solução. Como escreveu recentemente Donald Morrison, "não há algoritmo nem dose de força bruta filológica que possam demonstrar a presença da ironia a quem não a vê, ou o contrário". Por exemplo, continua Morrison, Rowe (como tantos outros) vê ironia na famosa passagem acerca da expulsão dos adultos da cidade, enquanto que "eu não vejo ironia naquela sugestão, e não creio que Platão a tenha visto" (p. 241). Convém deixar a pulga na orelha mais ou menos fina do leitor, como parece entender Morrison?

Não creio. Entre a submersão total dos textos na dimensão irônica e a sua leitura estritamente literal (igualmente inaceitável, porque está fora de dúvida que há ironia em Platão e no "seu" Sócrates) há uma possibilidade intermédia, assinalada provavelmente por uma série de indícios textuais que é preciso 'joeiar' com atenção analítica. 
Vou limitar-me só a dois exemplos dentre os muitos possíveis. Introduzindo no livro VIII da República o "discurso das Musas", que pretende formular aquele misterioso número nupcial, cujo cálculo errado determina a degeneração da kallipolis primordial, Sócrates diz: "Deixemos falar as Musas em sublime estilo trágico (tragikós), como se falassem a sério, quando, na realidade, brincam e zombam connosco como se fôssemos crianças" (545e: note-se que o advérbio tragikós aparece numa troca de galhardetes decididamente cômica, em III 413b).

No Político, após a narração mítica do "reino de Cronos" (quer seja idade do ouro ou país da alegria), perguntamo-nos se os homens de então eram mais felizes do que os de hoje. Se usavam o tempo livre em função da filosofia, responde o Estrangeiro, certamente sim. "Se, por outro lado, enchendo-se de comida e de bebida até à saciedade, narravam entre si e aos animais os mitos que também agora se contam sobre eles", então o juízo negativo é demasiado claro (272b-c).

Trata-se de dois exemplos inequívocos de ironia, e de ironia autorrefutadora, no sentido que convidam a não levar a sério aquilo que se está para dizer ou se acabou de dizer. Não é o caso de delinear uma tipologia das situaçōes irônicas frequentes nos diálogos. Bastará concluir que um prudente critério metódico para a sua identificação requer que se detecte, em cada caso, os sinais textuais que permitam identificá-las como tais, e evitar interpretar como irônicas aquelas teses que ao leitor podem parecer surpreendentes ou inaceitáveis. 


\section{EROS}

O tema da censura platônica da corporeidade e, sobretudo, do eros, como razão suficiente para fazer considerar impossível (a nós e a Platão mesmo) a realização do desenho utópico, circula amplamente entre os intérpretes de orientação straussiana, mas, em particular, é colocado no centro do livro de David Roochnik, de 2003.

A filosofia e um diálogo filosófico como a República, argumenta Roochnik, requerem um investimento erótico, mas a kallipolis delineada no livro V suprime-o; portanto, se existe a kallipolis, não pode existir a República, mas se não houver a República, não há também a kallipolis (p. 69). A Kallipolis, "com o seu rígido sistema de classes e a feroz restrição do discurso, da ação e do eros, é infamously antidemocratic". Mas trata-se só de um momento dialético no interior do diálogo. $\mathrm{O}$ que serve - aos olhos de Platão - é um regime que permita "o florescimento do eros. Este regime é a democracia”. Por isso, "a República de Platão, longe de ser aquela condenação da democracia que normalmente se considera ser, é, de fato, um apoio condicionado (ou dialético) para a própria democracia” (p. 77). Vêse, portanto, que Popper estava errado.

Se realmente o projeto da kallipolis contivesse a total censura do eros, que Platão sabe bem que é conatural à estrutura humana além de à natureza filosófica, a tal ponto que escreve que as "necessidades eróticas" são mais agudas do que as "geométricas" (V 458d), poder-se-ia verdadeiramente defender que aquele pro- 
jeto deva ser qualificado como indesejável (sobretudo aos olhos do "erótico" Gláucon) e como impossível (embora a inferência à democracia permanecesse, em todo o caso, improvável). Mas é realmente assim?

Como já notara Grote, o que se põe sob o controle público na República é apenas a sexualidade reprodutiva, porque para Platão (e para as cidades gregas em geral) a geração da prole, a teknopoiia, constitui um serviço para a comunidade. Parece banal recordar um fato que Strauss e os seus seguidores esquecem completamente: para Platão, e para a cultura à qual ele pertence, a sexualidade reprodutiva não é a única nem a principal expressão erótica. E na kallipolis não está prevista nenhuma regulamentação para o eros homossexual, salvo os limites do bom gosto social indicados no livro III (403a-c). Mas há mais: cada tipo de relação sexual fora da idade reprodutiva é explicitamente autorizada; no caso de relaçōes que deem lugar à geração de filhos, a sanção pública refere-se a estes últimos, que não serão acolhidos como membros legítimos da comunidade, e não aos seus pais (V 461a-c). Prevê-se também, com o consentimento entusiasmante de Gláucon, que se conceda a quem se distingue por valor no campo de batalha a possibilidade de "fazer amor com quem quiser", homem ou mulher (V 468b-c). Longe de constituir uma estrutura repressiva do eros, a kallipolis parece legitimar uma promiscuidade sexual que vai muito além dos limites da tradição - dado que é consentida pela abolição do vínculo matrimonial -, uma promiscuidade que, como se viu, escandalizava com razão os seus primeiros leitores de época humanista. 
No livro VII da República, Platão prevê a relutância dos filósofos em aceitar a responsabilidade de governar a nova cidade, dado que não querem abandonar a especulação teórica que lhes é afim, uma relutância que impõe à polis onde fizeram a sua formação que recorra a medidas de persuasão e, possivelmente também, à coerção para exigir que contraiam a dívida que têm para com ela. Esta constrição exercida pela cidade sobre os filósofos causou grande impressão e uma notável falta de vontade exegética junto dos intérpretes, mesmo daqueles que não estão ligados à interpretação straussiana.

Pode-se já formular uma observação que poderia redimensionar o problema. A linguagem da constrição é efetivamente formulada a propósito da obrigação que os filósofos têm de voltar a descer à "caverna" da política (anankasteoi, 539e); mas, numa passagem imediatamente seguinte, quase sempre menosprezada pelos intérpretes, a mesma linguagem (anankasteon, 540a) regressa a propósito da obrigação dos filósofos, feitos cinquenta anos, de deixarem o governo para se dedicarem prevalentemente ao estudo das ideias e do bom. Tudo isto pareceria referir-se à tendência inativa das formas de vida política e filosófica a separar-se uma da outra e a afirmar a própria autonomia: portanto, não só os filósofos não querem abandonar os seus estudos para se dedicarem à política, como também, assim que tomam o poder, são obrigados a abandonálo para voltar àqueles estudos. Trata-se de uma tendência que o legislador da kallipolis exclui solenemen- 
te no livro $\mathrm{V}$ para garantir a salvação da cidade e da filosofia: "aquela maioria, cuja natureza tende agora para um destes polos [política e filosofia] excluindo o outro, seja obrigatoriamente [ex anankes] impedida" de perseguir esta separação (473d).

Mas para os intérpretes straussianos outra é a coisa que está em jogo. Trata-se dos dogmas da incompatibilidade entre filosofia e política; da superioridade ("teológica") da filosofia sobre a política; do perigo de toda a pretensão filosófica de conduzir a política a superar os limites que lhe são impostos pela sua natureza “mundana”. A kallipolis, portanto, é impossível (porque ninguém pode obrigar os filósofos, que precedem a fundação da kallipolis e que são a sua condição necessária, a deixarem-se envolver pela política) e, sobretudo, indesejável, pelos efeitos monstruosos que esta união contra natureza está destinada a produzir.

Escrevia Rosen em 1990: "O problema [...] de o estado descrito na República ser possível, ou ser considerado possível por Sócrates, é, por isso, de interesse secundário. $\mathrm{O}$ ponto decisivo é que ele é indesejável e, em particular, é indesejável para o filósofo" (p. 19). Segundo Giovanni Ferrari (2003), a política é inferior ao indivíduo porque ele, ao contrário da cidade, é capaz de filosofia, e a "filosofia, não o reino, é o mais elevado achievement humano” (pp. 90, 103). A República proporia, então, em última instância, a reivindicação da superioridade da vida filosófica sobre a vida política, da dimensão "divina”, própria da primeira, sobre a dimensão "humana" que constitui os limites da segunda. 
A este propósito, Ferrari é induzido a realizar uma grande distorção textual que merece ser assinalada, porque, na minha opinião, indica um preconceito exegético tipicamente straussiano. $\mathrm{Na}$ célebre passagem do livro VI sobre o "muro", Sócrates afirma que quem conseguir terminar a sua vida mantendo-se "puro", protegido da contaminação da política, exatamente como se estivesse atrás de um muro durante uma tempestade, terá obtido um resultado "não de pouca conta”; mas não, acrescenta, "o máximo" (ta megista), que teria conseguido num ambiente político propício como a kallipolis (496d-497a). Ferrari põe a hipótese de que megiston não significa "o melhor" (kalliston): um bom sistema político permanece "o maior resultado humano", mas "o mais belo" cabe apenas à obra divina, e à filosofia que a contempla (por isso, Platão preferiu escrever a República em vez de procurar a oportunidade de obter a grandeza política) (pp. 107-8).

Mas a posição mais articulada e também a mais convincente a propósito desta ordem de problemas parece ser aquela defendida recentemente por Rosen no seu livro de 2005. Criticando Strauss, e as suas posições anteriores, Rosen reconhece que seria absurdo atribuir a Platão a convicção da não desejabilidade e da impossibilidade das finalidades visadas com o projeto da República. A mensagem do diálogo seria, na realidade, mais complexo. Há na filosofia, e também em Platão, uma "tentação do poder" (p. 6), escreve Rosen apelando-se explicitamente a Nietzsche; tentação testemunhada pela Carta VII, que Rosen - distinguindo-se da maior parte dos estudiosos anglo-saxões 
das últimas décadas - reconhece como autêntica. Mas Platão teria consciência de que o governo do saber está destinado a levar à transformação da filosofia em ideologia, e do seu poder em tirania. Deste modo, por um lado, Sócrates "funda a tradição radical do Ocidente, segundo a qual a justiça deve ser perseguida mediante uma construção doutrinal” (p. 9), cujos resultados extremos se teriam manifestado no século XX. Por outro lado, Platão (e neste segundo estrato de significação Strauss volta a ter razão) "mostra-nos dramaticamente como a filosofia, tentando adquirir o poder político, se transforma em tirania”; resulta que os próprios filósofos "estão destinados a sucumbir mal se dedicam à obra de desvio da tradição e de reconstrução dos fundamentos de uma cidade justa, quer no discurso, quer também na ação" (p. 10). A terapia filosófica está destinada a matar o paciente, isto é, a natureza humana; o "homem novo" que ela pretende criar corre o risco de se transformar num monstro. Portanto, o desejo filosófico de poder está inevitavelmente exposto a um paradoxo: ao adquirir poder, ele perde a sua justificação de o exercer. Rosen não hesita em forçar o texto para pintar este paradoxo com pinceladas sombrias. Referindo-se à passagem do livro VII sobre a expulsão dos adultos para o campo (eis agrous), Rosen interpreta-o no sentido de eles terem de ser mortos: "um ato fundador que nos pede que matemos quem quer que supere os dez anos de idade, dificilmente poderá constituir a base da justiça [...]. Para instituir uma cidade justa, é pedido um ato extremo de injustiça”" (p. 244).

O sentido da mensagem platônica consiste, então, em "expressar simultaneamente a necessidade que a 
política tem de filosofia, e o perigo de uma para a outra". Com tons que estranhamente lembram os de Hildebrandt, afirma Rosen: "A publicação da República é uma espécie de realização condensada das ambições políticas de Platão e uma ilustração dramática do fracasso das suas viagens na Sicília”. Apesar da perspicaz consciência platônica acerca dos riscos da política para a filosofia, e da filosofia para a política, que o diálogo testemunha, o resultado histórico da República seria bem diferente: ela constituiria a causa mais influente de deterioração da filosofia em ideologia, produzindo a sua politização extrema (p. 229).

A análise de Rosen (que certamente foi influenciada pela discussão sobre a tirania entre Strauss e Kojève, a propósito do Hierão de Xenofonte) é importante e digna de reflexão. $\mathrm{O}$ seu limite consiste, talvez, em usar, como já fizera Strauss, conceitos como "filosofia", "política" e "tirania" em sentido fortemente abstrato, quase como se se tratasse de entidades histórica e socialmente invariantes.

De um ponto de vista histórico, por exemplo, é lícito perguntar-se se Platão realmente considerava uma "monstruosidade" a perspectiva de um tirania filosófica, isto é, exercida ou aconselhada pelo filósofo. Afinal, as tiranias do século IV representavam um modelo político de sucesso e fascinante para a intelligencjia grega, depois da paralela decadência dos tradicionais regimes oligárquico e democrático. Basta apenas recordar a passagem muito explícita do livro IV das Leis. "Deem-me, pede o futuro legislador-filósofo, uma cidade regida por um tirano [...] se a cidade tiver de 
dotar-se, no modo mais rápido e melhor possível, de uma constituição que, assim que for realizada, lhe permita gozar da máxima felicidade. Não há nem haverá modo mais rápido e eficaz do que este para estabelecer uma constituição" (709e-710b) (uma passagem, entenda-se, que tanto os intérpretes straussianos quanto os "liberais" consideram irônica).

É, todavia, difícil de negar que há em Platão uma tensão entre filosofia e política. De um lado está a irreparável distância entre filósofo e a cidade dramatizada no Górgias e no Teeteto; do outro, a íntima relação, embora conflitual, entre República, Político e Carta VII. Esta tensão reflete provavelmente a colocação histórica de Platão, um intelectual aristocrático que se situa entre a tradição pitagórica e a de Sólon - da qual deriva a vocação régia da filosofia -, e, por outro lado, a figura de um filósofo de profissão à maneira de Aristóteles (que estruturaria esta tensão em textos como a Politica VII e Ética a Nicómaco X). Mas, tomado isoladamente, a mensagem da República parece em si mesma inequívoca: sejam quais forem os riscos desta ligação, a cidade é necessária para a salvação da filosofia, e a filosofia é necessária para a salvação da cidade.

\section{NOTA BIBLIOGRÁFICA}

Para asinterpretaçōesliberais-democratas:C.L.GRISWOLD, Le libéralisme platonicien: de la perfection individuelle comme fondement d'une théorie politique, in Contre Platon, t. II: Le 
platonisme renversé, par M. Dixsaut, Paris: Vrin 1995, pp. 155-95; para Sócrates, cf. G. VLASTOS, Socratic Studies, Cambridge: Cambridge University Press, 1994; R. KRAUT, Sócrates and the State, Princeton: Princeton University Press, 1984; para as Leis, cf. C. BOBONICH, Plato's Utopia Recast: His Later Ethics and Politics, Oxford: Clarendon 2002; para a República, cf. A. W. SAXONHOUSE, Athenian Democracy. Modern Mythmakers and Ancient Theorists, Notre Dame (IN)-London: University of Notre Dame Press, 1996, e, sobretudo, S. S. MONOSON, Plato's Democratic Entanglements. Athenian Politics and the Pratice of Philosophy, Princeton: Princeton University Press, 2000.

Para a crítica destas interpretações, $c f$. J.-F. PRADEAU, Platon, les démocrates et la démocratie, Napoli: Bibliopolis, 2005; L. BERTELLI, Platone contro la democrazia (e l'oligarchia), in CR VI, 2005, pp. 295-396. Em particular, para o Politico, cf. C. J. ROWE, Killing Sócrates: Plato's Later Thoughts on Democracy, in "Journal of Hellenic Studies", 121 (2001), pp. 63-76. Uma equilibrada releitura das teses de Vlastos e Griswold encontra- se em F. DE LUISE, G. FARINETTI, Infelicità degli archontes e felicità della polis, in CR III, 1998, pp. 107-50. Textos e comentário em F. FERRARI, Platone contro la democrazia, Milano: Rizzoli, 2008.

Sobre a utopia, $c f$. H. G. GADAMER, Platone e il pensare in utopie (1983), tradução italiana em L'anima alle soglie del pensiero nella filosofia grega, Napoli: Istituto di Studi Filosofici, 1988, pp. 61-91; Platone e $i$ poeti (1934), tradução italiana em Id., Studi Platonici I, Genova: Marietti, 1983, pp. 185-215. Sobre Gadamer e Platão, $c f$., em geral, F. RENAUD, Die Resokratisierung Platons. Die platonische Hermeneutik Hans-Georg Gadamers, Sankt 
Augustin: Academia, 1999. Sobre os conceitos de utopia, $c f$. M. I. FINLEY, Utopie antiche e moderne (1971), tradução italiana em Id., Uso e abuso della storia, Torino: Einaudi 1981, pp. 267-89.

Para L. STRAUSS, $c f$. The City and Man, Chicago: University of Chicago Press 1964 (pp. 50-138); L. STRAUSS, J. CROPSEY, History of Political Philosophy I (1963), tradução italiana (medíocre) Genova: il Melangolo 1993 (pp. 10577); Liberalismo antico e moderno, tradução italiana Milano: Giuffré 1973 (pp. 277-321). Acerca de Strauss em geral, cf. C. ALTINI, Leo Strauss, Bologna: Il Mulino, 2000; MATTEO VEGETTI, Il politico e la Legge. La "serietà della politica" in Leo Strauss e Carl Schmitt, no prelo.

A citação de M. F. BURNYEAT encontra-se em Sphinx Without a Secret, in "The New York Review of Books", May 30, 1985, pp. 30-6 (pp. 33, 35). As obras de orientação straussiana são citadas na seguinte ordem: R. S. BRUMBAUGH, Platonic Studies of Greek Philosophy, Albany: State University of New York Press, 1989; A. BLOOM, The Republic of Plato, transl. and interpretative essay, New York: Basic Books 19912; D. A. HYLAND, Taking the Longer Road: The Irony of Plato's 'Republic', in "Revue de Métaphysique et de Morale", 93 (1988), pp. 317-35; S. ROSEN, Plato's 'Republic'. A Study, New HavenLondon: Yale University Press, 2005; para o comentário de D. R. MORRISON, cf. The Utopian Character of Plato's Ideal City, in The Cambridge Companion to Plato's 'Republic', edited by G. R. F. Ferrari, Cambridge: Cambridge University Press, 2007, pp. 235-55; D. ROOCHNIK, Beautiful City. The Dialectical Character of Plato's 'Republic', Ithaca (NY)-London: Cornell University Press, 2003; S. ROSEN, Introduzione alla 'Repubblica' di Platone, Napoli: 
Istituto di Studi Filosofici, 1990; G. R. F. FERRARI, City and Soul in Plato's 'Republic', Sankt Augustin: Academia, 2003.

Para a discussão sobre o Hierão de Xenofonte, $c f$. L. STRAUSS, A. KOJÈVE, On Tyranny, New York: The Free Press 1991 (tradução francesa Paris: Gallimard 1997). Cf., a propósito, M. VEGETTI, Da Ierone a Stalin. La discussione fra Strauss e Kojève sullo 'Terone' di Senofonte, in F. Lisi, J.-F. Pradeau (éds.), Le philosophe, le roi, le tyran. Études sur les figures royale et tyrannique dans la pensée politique grecque et sa posterité, Sankt Augustin: Academia, 2009.

Para um balanço da questão da relação entre filosofia e política em Platão, $c f$. M. VEGETTI, Il regno filosofico, in CR IV, 2000, pp. 335-64. 
8.

\title{
PLATÃO SEM POLÍTICA
}

\section{PLATÃO IMPOLÍTICO}

\begin{abstract}
A estratégia que consiste em negar a Platão quaisquer interesses e engajamento, teórico e prático, na dimensão política, é certamente a mais perigosa, porque obriga os intérpretes a confrontar-se com uma evidência textual imponente, e com o consenso quase unânime de uma tradição exegética plurissecular, que vai de Aristóteles ao mesmo Strauss (com a exceção parcial de Proclo). Esta tática extrema, se coroada de sucesso, todavia, apresenta uma dupla vantagem para os seus defensores: refutar definitivamente Popper, mostrando que a sua tese requisitória se dirigia a um Platão político inexistente; libertar Platão do vestígio embaraçoso de um radicalismo político que o torna estranho ao âmago tranquilizador do pensamento liberal-democrata. Estas vantagens explicam, creio, a
\end{abstract}


difusão recente da linha interpretativa despolitizante, apesar das suas dificuldades intrínsecas.

A montante, além do Jaeger "americano", que negava quaisquer destinos políticos à Academia, deve ser mencionado o seu anômalo precursor: trata-se do grande filósofo da política Erich Vögelin. Tal como Strauss (do qual se diferencia apenas pelo catolicismo), Vögelin é um crítico da modernidade e um defensor da necessidade de subordinar a política a uma ordem superior, teologicamente fundada; a tradiçāoo clássica e, em primeiro lugar, Platão são revistos segundo esta prespectiva.

No capítulo platônico da sua monumental obra Ordem e história, Vögelin não nega absolutamente a centralidade da política no pensamento e na obra do filósofo, aliás, descritos com tons que às vezes parecem ser os de Hildebrandt, e segue de perto o movimento dialogal da República. Na conclusão do diálogo, porém, ele faz uma inversão radical de perspectiva. $\mathrm{O}$ fracasso prático do empenho político de Platão, que no livro VI é generalizado teoricamente pela tese da impossibilidade da ação política do filósofo na cidade hostil, transforma o sentido da "politeia interior", a boa constituição da alma, que de simples metáfora da polis se torna a descrição de uma realidade existencial. Comentando a passagem do livro IX (592a-b) que já se mencionou e do qual voltarei a falar no final do parágrafo, Vögelin escreve que "a investigação sobre o paradigma de uma nova polis ganha o aspecto de uma investigação sobre a existência do homem numa comunidade que transcende não só a polis, mas qualquer ordem política histórica. O salto para o ser - para 
a forma transcendente da ordem - dá-se verdadeiramente em Platão: e as eras seguintes reconheceram corretamente nesta passagem uma prefiguração da conceção agostiniana da Civitas dei" (p. 150). Trata-se de uma "deslocação definitiva na direção da alma e na da sua ordem transcendente [...] uma politeia transpolítica que se encontra no céu e que será realizada na alma de quem a observa" (p. 151).

Vögelin configurava desta forma a transição da República da dimensão política à dimensão moral e religiosa. Diversamente dele, os defensores recentes da despolitização de Platão (que, com efeito, não o mencionam), afirmam que a passagem da política à moral (com ou sem saída transcendente) não é o resultado de um movimento dialético da República, mas constitui a sua estrutura total: todo o discurso político deve ser concebido como uma metáfora da ordem moral da alma.

Por esta via se encaminhou certamente Julia Annas, em dois ensaios de 1997 e de 1999. A sua argumentação tende, em primeiro lugar, a enfraquecer o caráter político da República, até o pôr radicalmente em questão. Por exemplo, é interessante a recusa em atribuir qualquer pertinência política às análises da democracia e da oligarquia no livro VIII: só o Político e as Leis, que caracterizam os dois regimes como governo da massa e governo de poucos, teriam alguma pertinência política. Mas é evidentemente apenas um preconceito da intérprete que faz com que se considere "impolítica" a respectiva definição como governo dos pobres e dos ricos (aliás, igualmente retomada por Aristóteles). 
Quanto às "vagas" do livro V (abolição da família e da propriedade privada para a classe dos governantes, comportamento em guerra, poder filosófico), Annas escreve no ensaio de 1997: "Esta parte mais abertamente política da República parece descurar as realidades políticas tão deliberadamente que sempre houve uma dúvida quanto à seriedade das intençôes de Platão e, mais em geral, sobre o papel dos argumentos políticos da República em relação ao argumento moral principal" (p. 144); ainda: "as propostas políticas são absurdas, se tomadas à letra; elas parecem arbitrária e deliberadamente não realistas" (p. 145), além de "breves, insuficientemente desenvolvidas, marginais" (1999, p. 82). Para concluir: as ideias políticas do diálogo são apresentadas de such sketchy, incompleteand extreme ways que faz com que as consideremos estranhas à "tradição séria" da filosofia política à maneira de Locke e de Hobbes (1997, pp. 152-3).

De resto, nada na biografia platônica que conhecemos (considerando a Carta VII inautêntica ou documento irrelevante) pode fazer-nos pensar num interesse seu pela política, nem este interesse pode ser atribuído à Academia, defende Annas, limitando-se a mencionar a tese de Brunt sem discutir sequer as fontes (1997, pp. 155 segs.).

O que é então a República, se o seu tema não é a polis ideal? O fato de ela ser retomada no Timeu permite, segundo Annas, à luz do mito da Atlântida, formular uma primeira resposta: aquele mito "sugere fortemente que na República Platão pense, a propósito destes detalhes [tais seriam a aboliçãao da família e da proprie- 
dade privada, ou a paridade entre os sexos], da mesma maneira, ou seja, mais como construçôes imaginárias do que como argumentos sérios para a discussão política, para não falar de propostas práticas" (1999, p. 91).

Mais atentamente Annas refere-se à passagem do livro II, onde a investigação da justiça no indivíduo se desloca para o âmbito da polis, concebido como um texto igual mas escrito com carateres maiores e, por conseguinte, de leitura mais rápida: a passagem à política representa, portanto, só um percurso útil para responder à questão inicial.

A via para uma correta leitura da República é-nos, então, indicada pelos comentadores médio-platônicos, como Alcínoo, que liam nela um texto de ética que visava afirmar, à maneira socrático-estóica, a autossuficiência da virtude em vista da felicidade (1997, pp. 146 segs.; 1999, pp. 84 segs.). Se esta é, de fato, a tese moral da República, como Annas procura demonstrar, então a questão da desejabilidade e possibilidade do estado ideal torna-se completamente irrelevante, porque ele não é necessário para a completude da virtude e para a felicidade que dela deriva (1999, pp. 88 seg.). Por isso, o desenho da kallipolis tem unicamente a "função de permitir ao indivíduo a formação de uma ideia de virtude que ele possa interiorizar e seguir na vida” (1997, p. 145), escreve Annas com a inevitável referência à passagem do livro IX 592a-b. A discussão acerca do estado ideal não tem relevância política: ela é introduzida para "iluminar a alma" mediante a poderosa metáfora da hierarquia das partes, que consti- 
tui um modelo para a ordem moral individual; o seu papel, repete Annas, é "tornar o indivíduo capaz de alcançar uma ideia de moralidade que possa interiorizar" na sua vida virtuosa (1999, pp. 80 seg.).

A República, com a sua embaraçante herança, é expulsa da história da filosofia política, e reduzida a uma espécie de texto ético que antecipa o estoicismo; quando muito pode-se reconhecer algum interesse político no Político e nas Leis, onde a analogia entre alma e cidade é menos marcante, pelo menos porque póem em discussão aquele direito ao governo de quem possui uma expertise política, afirmado mas não argumentado na República (1999, p. 90). De resto, como se sabe, estes diálogos gozam de maior fama porque foram considerados, com razão ou não, mais "liberais" do que a República.

As teses de Annas parecem tão fortes como sumariamente argumentadas, sketchy and incomplete, para usar os termos que a autora atribui à República; o seu sucesso junto de uma parte dos estudiosos parece dever-se mais ao fato de os argumentos oferecerem uma resposta definitiva a Popper (e ao Platão "mestre ruim") do que a uma intrínseca capacidade de análise do texto.

Um esforço importante para uma melhor articulação da tese "metafórica", que não nega de todo uma valência política à República mas a passa para segundo plano relativamente à questão da alma individual, foi levado a cabo por Norbert Blössner (1997) e em seguida por Giovanni Ferrari (2003), que discutem, sobretudo, os livros VIII e IX do diálogo.

$\mathrm{O}$ primeiro desenvolve de maneira radical a tese de que as posições teóricas são dependentes do con- 
texto dialogal onde elas são propostas. Após ter identificado as contradiçóes inerentes à suposta homologia entre alma e cidade, Blössner conclui que Platão não cria uma verdadeira construção teórica, mas uma "técnica literária” metafórica, dotada de um grande potencial persuasivo face a interlocutores como Gláucon e Adimanto, prontos a compreender a linguagem da política: o objetivo é convencê-los da conexão necessária entre ordem moral da alma e felicidade (pp. 165, 212). Por exemplo, o modelo dos conflitos políticos, que se mostram logo evidentes, visa ilustrar metaforicamente os conflitos interiores da alma, que podem escapar a indivíduos pouco propensos à introspeção (p. 169, nota 462). A aproximação dialógica leva Blössner a considerar a República uma obra não primariamente política, mas destinada, sobretudo, a fazer luz sobre a organização e a ordem da alma, e a convencer-nos dos resultados eudaimônicos da justiça (pp. 190 segs.).

Com base nas dificuldades apresentadas pela relação entre tipos individuais e regimes políticos desenhada no livro VIII da República, Ferrari, mesmo admitindo a presença de uma dimensão política no diálogo, nega, por sua vez, a possibilidade de instituir uma relação de dependência causal entre cidade e alma (a primeira não determina a ordem da segunda, nem os tipos psicológicos determinam os regimes da primeira), salvo em casos extremos do reino filosófico e da tirania, onde, com efeito, há uma correspondência perfeita, e excecional, entre a ordem política e a psicológica dos homens no poder. Em casos normais, a correspondência é, pelo contrário, apenas analógica: a 
razão está para a alma como o governo está para a cidade (pp. 50, 61, 65 seg.). Deste modo, afirma Ferrari, "a alma parece radicalmente disengaged em relação à cidade" (p. 50), o que equivale a dizer - à maneira de Annas - que o regime político é irrelevante relativamente à "constituição interior" da alma. A relação analógica permite fazer compreender melhor ao leitor a estrutura dos elementos postos em relação metafórica (por exemplo, a anarquia pessoal do "homem democrático" ilumina a anarquia da cidade democrática, e vice-versa), apesar de eles não exercerem nenhuma causalidade recíproca. A consequência desta análise é, segundo Ferrari, que a República "focaliza mais a alma que a cidade, e exalta o indivíduo colocando-o acima da sociedade" (p. 89): como se viu, esta segunda conclusão depende da tese straussiana que afirma a superioridade da filosofia sobre a política e, por conseguinte, a superioridade do indivíduo, que for capaz, sobre a cidade.

Deve-se, todavia, observar que estes estudiosos descuram passagens cruciais onde Platão parece instituir uma relação não metafórica, mas de dependência bicondicional, entre alma e cidade. Em primeiro lugar, há um texto memorável da República VI onde se descreve a influência positiva e negativa da cidade (neste caso democrática) sobre a alma dos jovens, que convém citar completamente.

"Quando", disse, "se sentam em massa nas assembleias ou nos tribunais, ou nos teatros, ou nos acampamentos, ou em qualquer ou- 
tra reunião comum de multidão, com grande barulho ora desaprovam, ora elogiam os discursos e as ações, e exageram quer nos berros de desaprovação quer nos aplausos, de modo que até as pedras e o lugar onde se encontram fazem-lhes de eco redobrando o barulho da desaprovação e do louvor. Em tais situações, que coração - segundo o ditado - pensas que pode ter o jovem? Que educação privada poderia resistir nele sem ser atropelada por um tal fluxo de desaprovações e de elogios, sem se deixar transportar para onde a corrente o leva? Não dirá, talvez, que são belas e feias as mesmas coisas que a multidão pensa, não adotará o mesmo estilo de vida, as mesmas ocupações, tornando-se um deles?". "É realmente necessário, Sócrates", disse ele. "E olha", disse eu, "que ainda não falamos da necessidade maior". "Qual?", disse. "Aquela que estes educadores ou sofistas acrescentam com os fatos, quando não conseguem convencer com as palavras: ou talvez não saibas que quem não se deixa convencer é punido com a privação dos direitos, com as confiscas, com as condenações à morte?" (492b-d).

Pelo contrário, pode recordar-se, por exemplo, a influência positiva que a cidade justa, com as suas açôes e até com os seus edifícios, exerce sobre a alma dos jovens, "como uma aura que traz saúde, provindo de lugares benéficos", induzindo a alma a conformar-se com a "bela razão" (III 401c-d). Ao invés, quanto à relação 
de causação entre tipos de alma individual e regime político, bastará lembrar a passagem em que Platão exclui que as "constituições nasçam de um carvalho ou de uma rocha", e não dos caracteres de quem vive nas cidades (VIII 544d-e; veja-se também IV 435e seg.).

Não obstante o caráter inegavelmente imperfeito da homologia entre alma e cidade esboçada no livro IV e retomada no livro VIII, à luz destas e de muitas outras passagens semelhantes, parece verdadeiramente difícil negar que a cidade exerça uma influência causal sobre a conformação interior da alma, positiva ou negativa, segundo os diversos regimes (e vice-versa: a cidade má forma uma alma medíocre que deseja viver numa cidade que lhe é homogênea). Por conseguinte, é igualmente difícil defender que um bom governo, como o da kallipolis, não seja influente e relevante para a auto-configuração moral do indivíduo, e que a dimensão moral pessoal seja de todo independente do ambiente em que se vive. Mas se assim é, entâo torna-se impossível despolitizar o sentido total da República, em vista de uma destinação moral prevalecente, ou exclusiva. Apesar de ser para muitos desagradável, e exposta a críticas de tipo popperiano, a dimensão política da República pareceria ser, pelo menos, tão relevante como a dimensão ética.

\section{KATOIKIZEIN}

Tem-se feito muitas vezes referência, neste capítulo e no anterior, à passagem do livro IX da República, que constitui o maior ponto de força textual para os 
intérpretes que querem negar, ou enfraquecer, o caráter político do diálogo, lendo-o, pelo contrário, como uma investigação sobre a moral individual. É, pois, o caso de discuti-la com a atenção necessária.

Após uma longa análise, que descreveu o comportamento moral do homem justo numa sociedade diversa da kallipolis, Sócrates conclui:

O mesmo acontece com as honras: ao visar o mesmo objetivo [isto é, a preservação integral da sua politeia interior, 591e], de boa vontade frequentará e usufruirá daqueles que ele pensa que o possam tornar melhor, e fugirá, privada ou publicamente, dos que correm o risco de arruinar a estabilidade da sua condição.

Por isso, disse Gláucon, não quererá, decerto, fazer atividade política, se for dela que se ocupa.

Pelo Cão, disse eu, fá-lo-á, e muita até, na cidade que é sua, talvez não na sua pátria, a não ser que se dê alguma sorte divina.

Percebo, disse: queres dizer na cidade cuja fundação estamos discutindo, a que está nos discursos, pois não penso que ela exista em nenhum lugar da terra.

Mas talvez, disse, esteja no céu como um modelo [paradeigma], à disposição de quem o queira ver, e tendo como objetivo heautòn katoikizein. Mas não faz nenhuma diferença se ela existe em algum lugar ou se existirá no futuro: ele poderá agir só em vista da política desta cidade, e de mais nenhuma (592a-b). 
O problema crucial está na interpretação das duas palavras que deixei em grego transliterado. No início do século XX, o grande comentador inglês Joseph Adam traduzia-as em found a city in himself, seguindo talvez, legitimando certamente, um preconceito exegético persistente. $\mathrm{O}$ texto parecia, então, dizer claramente: 1 . a realização do projeto da kallipolis no tempo histórico é impossível; 2. de toda a forma, é irrelevante, porque a sua função consiste em fornecer um modelo a ser interiorizado para construir a virtude individual, para "refundar-se a si mesmo" segundo o paradigma da justiça; 3. dado que o homem justo agiria politicamente somente na cidade justa, que não pode existir, manifesta-se a sua radical estranheza à política. O sentido da República consistiria, então, em última instância, na separação de moral individual (onde é possível fundar a virtude) da dimensão política (onde é impossível fundar a cidade justa).

Creio, todavia, ter demonstrado (2005) que a tradução de Adam, tão propícia a confirmar a exegese impolítica da República, não é sustentável do ponto de vista linguístico. Katoikizein com acusativo vale normalmente, em grego e em Platão, "ocupar, transferir, fazer habitar" alguém em algum lugar; muitas vezes designa o "fundar uma colónia", fazendo com que a população ocupe uma nova localidade. Na nossa passagem, portanto, o sujeito que tenha decidido abandonar a política da própria pátria histórica "transferir-se-á para" o "céu" do paradigma, isto é, na perspectiva teórica da cidade justa (também Morrison aceita esta exegese, 2007: make himself its citizen). Para isto, são necessárias duas decisões. A primeira, de or- 
dem intelectual, consiste em querer compreender o paradigma teórico (confira-se $472 \mathrm{~d}$ : "produzimos no discurso, o paradigma da cidade boa”); a segunda, de ordem moral, comporta o querer mudar o próprio habitat político, continuando a visar aquele paradigma. À luz destas premissas, compreende-se melhor o que vem depois, que tem literalmente este valor: "fará as coisas desta cidade apenas, e de nenhuma outra". O sentido político da República decide-se com esta frase. Ela encerra dois significados que não podem ser separados. O primeiro é que o homem justo (o filósofo), obviamente, concentrará o máximo da sua atividade política na nova cidade, em vista da sua conservação. O segundo é que ele, se agir na pátria histórica, fá-lo-á só em vista e em função do advento da outra cidade: isto não se exclui, mas pode acontecer só com o favor daquelas circunstâncias excepcionais que Platão indica como uma "sorte divina".

Corretamente traduzida e interpretada, a nossa passagem não constitui de maneira nenhuma uma prova do caráter essencialmente não político, e dirigido à interioridade moral do indivíduo, da República. Ela retoma de perto o lugar importante do livro VI, onde se afirma que em vez de se limitar a "plasmar só a si mesmo", o filósofo pode encontrar-se na situação de ser induzido pelas circunstâncias a transformar a cidade segundo "a ordem que vê lá em cima” (500d), ou seja, no "céu" da teoria normativa. Não se trata, pois, em ambos os casos, de se limitar à interiorização da norma moral, mas de iniciar uma ação política transformadora da cidade histórica, mesmo que ela seja possível só em condições excepcionalmente favoráveis. 


\section{A QUESTÃO DA CARTA VII}

É claro que a avaliação do envolvimento político de Platão, é, por conseguinte, também da relação entre República e âmbito da política, depende, pelo menos, em parte do problema historiográfico posto por aquela espécie de autobiografia em forma epistolar que nos chegou com o título Carta VII (dirigida "aos amigos de Díon" e que pode ser datada em torno a 353).

É o caso, antes de tudo, de dar brevemente conta dos conteúdos pertinentes ao problema.

Platão conta, assim, a sua experiência enquanto jovem.

Quando era jovem, partilhei uma paixão comum a muitos; pensava: assim que alcançar a minha independência, entro na vida política da cidade (324b).

Nada de estranho nisto, visto a pertença de Platão a uma das famílias mais renomadas de Atenas, e envolvida na história política da cidade quer pela sua genealogia, que remontava a Sólon, quer pela direta participação de muitos dos seus membros nela. Entre eles havia Crítias e Cármides, tio e irmão da mãe de Platão, os protagonistas principais do golpe de estado oligárquico que em 404 derrubou a democracia ateniense, instaurando o chamado regime dos "Trinta tiranos". Ao jovem Platão foi proposto, claramente, um envolvimento nesta aventura; todavia, o regime dos Trinta tiranos cedo lhe desagradou pela sua violência opressiva. 
Afastei-me, pois, com indignação daqueles crimes. Não muito tempo depois caíram os Trinta e todo o seu regime. De novo, embora com menor impaciência, tomou-me o desejo de me empenhar na vida política e nas ações públicas (352a-b).

O restaurado regime democrático manchou-se bem cedo de um crime fatal aos olhos de Platão e dos seus companheiros: o processo e a condenação à morte de Sócrates, o mestre de tantos jovens aristocráticos atenienses (399). A condenação de Sócrates marcou, para Platão, uma fratura incurável entre a sua vocação filosófica e a política ateniense.

Voltei a refletir sobre tudo isto - os homens que faziam política, as leis, os costumes - e quanto mais avançava na idade, mais me parecia difícil governar corretamente a vida política. Convencia-me de que não era possível fazer nada sem homens que fossem amigos e companheiros de confiança (352c-d).

Estas palavras refletem a solidão de Sócrates, a trágica impotência da sua tentativa de influir sobre a condução política da cidade e, por outro lado, antecipam a fundação da Academia, com a intenção de constituir aquele grupo de "amigos e companheiros" com os quais enfrentar tanto a investigação filosófica, quanto o eventual empenho na política. Entretanto, Platão continua a observar a situação, "aguardando sempre o momento propício para a ação”, e chega à 
conclusão, destinada a formar o centro da República, segundo a qual só a união de filosofia e poder político poderia sanear os males da cidade (326a-b).

É com esta convicção, segundo a Carta VII, que Platão se prepara para fazer a sua primeira viagem a Siracusa (388/7), a grande cidade governada pelo potente tirano Dionísio I. Quaisquer que fossem as intenções de Platão ao fazer esta viagem, talvez devida às pressões de Díon, um jovem aristocrata siracusano que o filósofo considerava o mais dotado dos seus alunos, elas revelaram-se uma desilusão e induziram Platão a um regresso rápido à pátria: a forma corrupta de vida da metrópole siciliana não parecia de forma alguma suscetível de melhoramento.

Vinte anos depois morria o tirano Dionísio I e lhe sucedia o filho Dionísio II. Díon estava convencido de que uma intervenção direta de Platão poderia "converter" o jovem tirano ao exercício de um governo "filosófico" (mas, talvez esperasse secretamente usar a autoridade do mestre para tomar, por sua vez, o poder). Relutante em aceitar a proposta, e ciente dos perigos que esta comportava, no fim, Platão decide ceder ante as insistências de Díon "porque me teria envergonhado muito de parecer a mim mesmo com um homem só de palavras, mas incapaz de se empenhar em qualquer ação" (328b).

A expedição de $366 / 5$ (que na narração do Díon de Plutarco parece uma verdadeira invasão da corte siracusana por parte dos Acadêmicos) consumiu-se rapidamente em nobres ingenuidades, ciúmes, suspeitas e intrigas. Primeiro, Dionísio II mandou exilar Díon, procurando reter Platão, depois foi obrigado a consen- 
tir que Platão regressasse a Atenas. Mas Platão, mais uma vez pela insistência de Díon, realizou em 361 a terceira tentativa siracusana, destinada a concluir-se de maneira ainda mais macabra e perigosa que as anteriores. Aqui termina o envolvimento direto de Platão nas vicissitudes siracusanas. Mas não o dos Acadêmicos, que em 357, sob o comando de Díon e com o apoio de Espeusipo (além de, provavelmente, com o tácito consenso do mestre), organizam uma expedição militar à Sicília: Dionísio é derrotado e deposto, e Díon toma o seu lugar, embora o seu poder acabe por resultar efêmero (de fato, morre em 354).

Este é o "testemunho" autobiográfico da Carta VII, destinado a cancelar a suspeita, junto da opinião publica siciliana e grega, que Platão e os Acadêmicos tivessem tramado algo para conquistar a tirania em Siracusa. É claro que, se fosse considerado autêntico, este autotestemunho eliminaria quaisquer dúvidas acerca das intençôes políticas de Platão e da direta interação entre filosofia e política por ele praticada.

A favor da autenticidade da epístola, geralmente aceite durante a primeira metade do século XX, militam algumas boas razões. A linguagem e a fidelidade aos textos platônicos conhecidos (em primeiro lugar, República e Leis) são tais que se o autor não fosse Platão, seria necessário supor a existência de um alter ego seu, um "segundo Platão", como diziam já os antigos (e como reconhecem recentemente Ferrari e Rosen). Há, todavia, outras tantas razóes para duvidar da sua autenticidade. A primeira é que a Carta VII pertence a um corpus de 13 epístolas no qual ela seria a única autêntica, devendo considerar-se as outras apócrifas, 
obra de falsários como todos os epistolários legados pela antiguidade. Mais especificamente, a carta apresenta, além de passagens dos textos platônicos de que o falsário poderia ter-se apropriado, considerações filosóficas que, pelo contrário, lhe parecem estranhas, tal como o célebre excursus (342a-344d) e, ainda, omissōes e imprecisões narrativas que dificilmente podem dever-se ao enfraquecimento da memória do velho Platão. Por fim, há a intenção apologética de justificar, post factum, as ações siracusanas de Platão e dos seus seguidores. No plano filológico, a questão da autenticidade é provavelmente indecidível, apesar dos esforços insistentes dos estudiosos de orientação oposta. Há, contudo, uma terceira e interessante possibilidade: que a carta, se não atribuível a Platão, seja, porém, devida a um "discípulo devoto" seu (Brunt), talvez ao mesmo Espeusipo (Finley), de qualquer forma, a uma testemunha bem informada (Bertelli), que podia ter à disposição aqueles domestica documenta, com base nas quais, segundo Apuleio, Espeusipo teria composto uma biografia de Platão. A Carta VII conservaria, assim, de forma intacta, o seu valor documental acerca dos interesses e o engajamento político de Platão e da Academia.

Os intérpretes interessados na despolitização de Platão e na expulsão do âmbito político da República não têm, todavia, este tipo de dúvidas. A sua linha prevalente (clara, sobretudo, em Annas) articula-se da seguinte forma: 1. a carta é certamente inautêntica: isto é asserido através da única referência ao importantíssimo ensaio de Edelstein, ignorando os parece- 
res opostos, quer anteriores a Edelstein (por exemplo, Wilamowitz, Stenzel e Maddalena), quer posteriores e recentes (por exemplo, von Fritz, Isnardi e Brisson); 2. a carta não tem, contudo, nenhum valor documental; autêntica ou não, ela pertence ao gênero literário epistolar, que não tem relevância histórica; 3. o caráter falso ou ficcional da carta invalida também o valor dos outros testemunhos relativos à política platônica, em primeiro lugar, os do Díon de Plutarco e de Filodemo, porque dependeriam exclusivamente dela (convém observar que os historiadores atribuem, ao invés, a Plutarco ótimas fontes independentes, como a carta que o acadêmico Timónides de Leucade enviou a Espeusipo para o informar dos eventos).

A questão da Carta VII é certamente destinada a permanecer em aberto, e o seu valor documental deve ser utilizado com muita cautela. Mas a resolução dogmática com a qual os intérpretes que negam interesses políticos a Platão e à República recusam qualquer relevância documental à epístola, contrariamente à maior parte dos historiadores, parece derivar mais de um preconceito exegético do que de uma cuidada análise do problema nos seus diferentes aspectos filológicos e historiográficos.

\section{UMA RÉPLICA ALÉM DO MURO: O STREIT UM PLATON NA DDR}

Uma espécie de réplica condensada do processo a Platão originado no Ocidente pela acusação de Popper teve lugar na DDR, nos fascículos de 1964 e 1965 da 
revista "Das Altertum". Na veste de acusador age aqui Georg Mende, professor em Jena, cujos argumentos apesar da radical diferença de linguagem e dos pontos de vista - apresentam uma notável semelhança com os de Popper.

Mende propõe-se pôr fim àquela tenaz Platonlegende que atribui às doutrinas do velho filósofo um valor atemporal e super partes. Na realidade, Platão foi, segundo o mote de Lenine, o fundador do "idealismo objetivo", e esta filosofia ofereceu o fundamento teórico à sua concepção política de uma "aristocracia do espírito", destinada ao governo, no qual se exprime somente a ideologia da aristocracia esclavagista grega. Portanto, conclui Mende, "Platão não tem mais nada a dizer à grande maioria dos homens de hoje"; no máximo, o seu pensamento oferece "um modelo experimentado aos inimigos de classe do povo".

O papel da defesa cabe a Rudolf Schottlaender. Tal como os primeiros defensores de Platão relativamente às acusaçôes de Popper, ele visa atenuar a gravidade das acusaçõos levantadas por Mende. Platão não é certamente um adepto da democracia socialista; todavia, nem sequer lhe pode ser atribuída uma ideologia de aristocrata esclavagista. A aristocracia do espírito que ele quer construir não coincide com a do nascimento, à qual ele dirige críticas duríssimas: trata-se de uma nova elite a ser selecionada pelos seus valores intelectuais e morais, e com um "revolucionário" projeto educativo que Schottlaender indica como um dos maiores méritos platônicos. Ele insiste também, com particular vigor, nos interesses científicos de Platão, da 
matemática à astronomia, à cosmologia, que vão além dos limites do seu "idealismo objetivo" e que são relevantes também para a história da formação do "materialismo científico".

Por fim, Schottlaender repete uma tática defensiva que bem conhecemos, a marginalização da República: afinal, ela não é a única obra de Platão nem o seu Hauptwerk; a crítica ideológica da República não pode, pois, envolver todo o pensamento platônico.

Um primeiro veredito foi pronunciado por Ekkehard Schwarzkopf. Ele crê que se deve confirmar a caracterização de Platão como ideólogo da aristocracia escravista. É verdade que a aristocracia por nascimento deve ser aperfeiçoada pela educação, mas a educação (e com ela também a filosofia) é sempre um privilégio da classe, do qual se exclui a massa dos trabalhadores manuais. Schwarzkopf introduz, porém, uma interessante anotação. Platão é o ideólogo da aristocracia esclavagista porque é um teórico crítico do desenvolvimento da produção de mercadorias. Mesmo em negativo, a sua posição constitui um momento dialético do processo que levará à crítica comunista da mercadoria (de resto, a forma primitiva do comunismo precede a da produção de mercadorias que Platão critica). Os limites objetivos do pensamento platônico devem-se ao mundo histórico-social no qual ele se formou (uma reformulação marxista da tese hegeliana, portanto), dominado pela aristocracia escravista como "classe necessária!".

Alguns anos mais tarde, o debate concluía-se na introdução densa e importante à República, escrita em 1978 por Hans-Martin Gerlach e Günter Schenk. Es- 
tes autores tendem, em primeiro lugar, a excluir Platão daquele lugar da história do comunismo utópico, que lhe fora reconhecido no início do século por socialistas como Kautski. Trata-se de um pensador conservadorreacionário porque teorizava a desigualdade natural entre os homens, sobre a qual se funda o seu projeto social. Igualmente drástica é, como se vê, a recusa da tentativa de Popper em estabelecer uma continuidade entre Platão e Marx mediante a sua "doutrina anticomunista do totalitarismo: a batalha ideológica conduzida por Popper contra o marxismo leva-o a ignorar as imensas diferenças sociais e teóricas entre os dois filósofos" (pp. 6 seg.).

Retomando Mende, Gerlach e Schenk reafirmam o nexo entre idealismo objetivo e ideologia da "aristocracia do espírito". A República, de fato, é construída mediante um processo de abstração idealista que, porém, parte de formas sociais reais: a Esparta conservadora, a hierarquia egípcia de castas (aqui aparece a citação costumeira do (apital), a ideologia elitista dos Pitagóricos (pp. 17 seg.). Mais em particular, Platão constrói o modelo de uma estrutura hierárquica de castas a partir da sua importante análise da divisão social do trabalho.

Mas, o projeto da República era impossível (nos fatos, não segundo o seu autor) porque visava mutar a estrutura da realidade histórica e econômica apenas com os instrumentos da ideologia e da política: uma luta vã para bloquear o progresso histórico (aqui os autores ecoam Popper), o desenvolvimento da produção e da economia financeira (p. 20, 33). "A Politeia de Platão, 
concluem, devia permanecer uma utopia”, mas uma utopia que, ao contrário daquelas modernas, apresenta um caráter conservador e reacionário (p. 21).

Processado em terra marxista-leninista, portanto, Platão não escapa à condenação. Aqui não são considerados aqueles instrumentos de defesa que teriam consentido a absolvição, ou pelo menos descontos de pena importantes, do filósofo (a pacto que se faça uma espécie de abjuração da República como texto político) no continente liberal-democrata, onde a acusação fora igualmente áspera e peremptória. Como se viu, negase-lhe também o direito de asilo naquela pré-história utópica do socialismo e do comunismo, que até estudiosos como Pölhmann e Natorp estavam dispostos a conceder-lhe. Tanta severidade deve-se, provavelmente, ao fato de o marxismo-leninismo ortodoxo não sentir a exigência de salvar a unidade da própria tradição intelectual que, pelo contrário - como defende Gadamer -, é uma necessidade vital para o Ocidente.

\section{NOTA BIBLIOGRÁFICA}

Sobre a despolitização de Platão, $c f$ : E. VÖGELIN, Ordine e storia. La filosofia politica di Platone (1966), tradução italiana Bologna: il Mulino, 1986; J. ANNAS, Politics and Ethics in Plato's 'Republic', in Platon. Politeia, herausgegeben von O. Höffe, Berlin: Akademie Verlag, 1997, pp. 141-60; EAD, The Inner City: Ethics without Politics in the 'Republic', in Ead., Platonic Ethics. Old and New, Ithaca (NY)-London: Cornell University Press, 1999, pp. 72-95; N. BLÖSSNER, 
Dialogform und Argument: Studien zur Platons 'Politeia', in "Akademie Mainz, Geistes-und Sozialwissenschaftlichen Klasse”, 1, Stuttgart: Steiner, 1997; ID, Kontextebezogenheit und argumentative Funktion: Methodische Anmerkungen zur Platondeutung, in "Hermes", 126 (1998), pp. 189-201; G. R. F. FERRARI, City and Soul in Plato's 'Republic', Sankt Augustin: Academia, 2003.

Sobre a interpretação de República IX 591-592, cf. M. VEGETTI, Il tempo, la storia, l'utopia, in CR VI, 2005, pp. 137-68 (pp. 156-62).

Sobre a questão da Carta VII: contra a autenticidade, L. EDELSTEIN, Plato's Seventh Letter, Leiden: Brill, 1966; a favor (com status quaestionis), L. BRISSON, Notice, in Platon. Lettres, Paris: Flammarion, 1987 (pp. 133-66); M. ISNARDI PARENTE, Filosofia e politica nelle lettere di Platone, Napoli: Guida, 1970; EAD., Introduzione a Platone, Lettere, a cura di M. G. Ciani, Milano: Mondadori 2002. Cf., também, M. I. FINLEY, Plato and Practical Politics, in Id., Aspects of Antiquity, Harmondsworth: Chatto \& Windus, 19772 (pp. 74- 87); K. VON FRITZ, Platon in Sizilien und das Problem der Philosophenherrschaft, Berlin: De Gruyter, 1968; L. BERTELLI, Platone contro la democrazia (e l'oligarchia), in CR VI, 2005, pp. 295-396 (pp. 295-307). Sobre o envolvimento político da Academia, cf. a documentação crítica em K. TRAMPEDACH, Platon, die Akademie und die zeitgenossische Politik, in "Hermes - Einselschriften", 66, Stuttgart, 1994; avaliaçôes em P. A. BRUNT, Studies in Greek History and Thought, Oxford: Oxford University Press 1993 (pp. 282-342) (excessivamente redutivo); M. ISNARDI PARENTE, L'Accademia antica e la politica del primo Ellenismo, in G. Casertano (a cura di), I filosofi e il potere nella società e nella 
cultura antiche, Napoli: Guida, 1988 (pp. 89-117); M. VEGETTI, Filosofia e politica: le avventure dell'Accademia, in F. Lisi (ed.), The Way of Life in Classical Political Philosophy, Sankt Augustin: Academia, 2004 (pp. 69-81). Sobre o testemunho de Plutarco, $c f$. M. SORDI, Il IV e III secolo da Dionigi I a Timoleonte, in E. Gabba, G. Vallet (a cura di), La Sicilia antica, II, 1, Palermo: Le Edizioni del Sole, 1980 (pp. 207-88); F. MUCCIOLI, Dionisio II. Storia e tradizione letteraria, Bologna: CLUEB, 1999 (além do já citado von Fritz).

Para o debate na DDR, $c f$. R. SCHOTTLAENDER, Der Streit um Platon, in "Das Altertum", 10 (1964), pp. 142-54; G. MENDE, Zum "Streit um Platon”, ivi, pp. 230-34; E. SCHWARZKOPF, Kritische Anmerkungen zum Streit um Platon, ivi, 11 (1965), pp. 137-43; H.M. GERLACH, G. SCHENK, Einleitung a Platon, Der Staat (tradução de O. Apelt), Leipzig: Reclam Bibliothek, 1978 (pp. 5-48). 
(Página deixada propositadamente em branco) 
9.

\section{A QUESTÃO DA UTOPIA}

\section{UTOPIAS DE EVASÃO}

Acerca do sonhar com os olhos abertos e do fantasiar. Prova de falta de caráter e de passividade. Imagina-se que um facto tenha acontecido e que o mecanismo da necessidade se tenha invertido. A iniciativa mesma se liberta. Tudo é fácil. Pode-se fazer aquilo que se quer, e quer-se toda uma série de coisas de que presentemente se está privado. É, no fundo, o presente de cabeça para baixo que se projeta no futuro. Tudo o que está reprimido rebenta. É necessário, ao invés, chamar a atenção para o presente tal como ele é, se o queremos transformar. Pessimismo da inteligência, otimismo da vontade.

São palavras de Antonio Gramsci, que desenham perfeitamente o quadro mental das "utopias de evasão" e a sua crítica. A República de Platão foi inseri- 
da neste quadro por uma longa tradição, começando com Pier Candido Decembrio (que falava de uma cidade votis magis quam rebus expetenda), passando pelas "Quimeras" de Brucker, chegando aos "castelos no ar" de Gadamer. Desta forma, a República era assimilada a toda uma série de utopias da idade do ouro, das ilhas beatas, dos países da alegria, que talvez inicie com Aristófanes, continue no helenismo e termine, naturalmente, com as grandes utopias da idade moderna, de Campanella a More, e outros: exatamente aquele tipo de utopias às quais se opunham com decisão, por ideias diferentes, quer Kant quer Hegel e a tradição hegeliana, começando por Marx, do qual bem se conhece o desprezo pelo "comunismo utópico".

Mas o mesmo Platão, quase como se tivesse previsto esta leitura, tomou todas as precauçóes para evitar que o desenho da kallipolis fosse considerado um substituto imaginário da realidade. Numa passagem decisiva, Sócrates pede uma licença provisória para se comportar como o gramsciano "sonhador com os olhos abertos", para antecipar a questão da desejabilidade à questão da possibilidade.

Faz-me um grande favor: oferece-me uma festa, como aqueles preguiçosos mentais que costumam banquetear com as suas fantasias quando passeiam sozinhos. Eles, com efeito, antes de encontrarem o modo com o qual se poderá realizar algo que desejam, descuram o problema para não adoecerem por tanto deliberarem sobre a sua possibilidade ou impossibilidade de realização; postulando como 
existente aquilo que desejam, passam logo a dispor tudo o resto, e gozam por isso passando em revista tudo o que farão assim que esse algo se realizar, tornando ainda mais preguiçosa uma alma que já é preguiçosa. Também eu me sinto tomado por essa moleza, e desejo adiar para mais tarde a investigação sobre a possibilidade daquelas coisas; agora, porém, tendo-as postulado como possíveis, examinarei, se mo concederes, como os governantes irão regular a sua realização, e mostrarei que, assim que forem postas em prática, nada poderá ser mais útil para a cidade e para os defensores. Isto procurarei, em primeiro lugar, investigar juntamente contigo e, em seguida, enfrentarei aqueloutros problemas, mas só se me permitires (V 458a-b).

Trata-se, portanto, de um reenvio provisório. Platão não se cansa de repetir que evitar a questão da possibilidade de realização significa permanecer no nível das euchai, ou seja, dos "votos", pios desejos, castelos no ar, e que isto seria, com razão, considerado ridículo (cf., por exemplo, V 450d, VI 499c). A República não pode, pois, ser colocada no âmbito das utopias de evasão, pelo menos nas intenções declaradas do seu autor.

\section{UTOPIA DE RECONSTRUÇÃO}

Como qualquer tipo de "utopia séria”, escreve Finley, a República não é uma fantasia de evasão da realidade, mas "é concebida como um fim que se pode 
legitimamente tentar e esperar alcançar": trata-se, portanto, de uma "utopia de reconstrução" social e moral. De fato, Platão reafirma mais do que uma vez um vínculo entrecruzado de desejabilidade e possibilidade do desenho utópico, que é expresso de forma eficaz através da tese de que as suas propostas são "as melhores, se realmente são possíveis", "ótimas, se realizáveis" (VI 502c). Um projeto que resultasse, por princípio, irrealizável não seria sequer desejável, porque cairia no "ridículo" das euchai: eis porque Platão insiste na possibilidade ou, pelo menos, na não impossibilidade de princípio, de uma qualquer forma de realização do projeto, apesar de repetir que é "difícil" (VI 499d, 502c, 504d).

Naturalmente, é inevitável prever uma separação, um décalage, entre o paradigma delineado no discurso e qualquer possível tradução histórica sua. Aquele paradigma é modelado a partir da ordem ideal da justiça, e a sua inserção no mundo da temporalidade histórica acarreta uma deformação: o filósofo-político, "pintor de constituições”, tentará reproduzir aquele modelo na tela da história com a maior fidelidade que a instabilidade e variabilidade das circunstâncias lhe consente (VI 501b-c). Há outra metáfora pictórica que parece contradizer esta: a bravura de um pintor não diminuiria, escreve Platão, se ele não conseguisse apresentar a existência de um homem tão belo como o que pintou (V 472d). A contradição é só aparente. No primeiro caso, o modelo é anterior ao desenho, que representa uma reprodução inevitavelmente imperfeita dele. Aqui, pelo contrário, o modelo é cons- 
tituído pelo próprio desenho - que representa o paradigma esboçado no discurso teórico - e a eventual réplica, que, de qualquer modo, não poderia ser igual a ele, deve ser buscada fora do modelo, no campo dos fatos reais. Ambas as metáforas convergem, pois, ao assinalar que a reprodutibilidade prática do paradigma, embora possível, nunca se adequa completamente a ele, o que não diminui a sua validade teórica. Não é errado pensar aqui (como sugeriam Pöhlmann e Natorp) no ideal kantiano, isto é, na ideia representada in individuo (a kallipolis).

Tudo isto consente que se fale, a propósito da República, de "utopia projetual". "Projetual" porque a sua realização é desejável e possível, ou, pelo menos, não impossível, embora seja difícil e necessariamente imperfeita. Mas é, contudo, pelo menos por alguns aspectos, uma "utopia”. Platão afirma que aquele projeto foi construído à maneira de uma ficção narrativa, de um conto mítico ("como se contássemos um mito", II 376d; "a constituição sobre a qual criamos mitos no discurso”, VI 501e; veja-se, no Timeu, a menção a "os cidadãos e a cidade que nos contavas ontem como um mito", 26c, com clara referência à República). O desenho utópico é, então, apresentado como um gesto de poderosa imaginação filosófica, um ato discursivo já dotado em si mesmo de eficácia.

A que se destina? Em primeiro lugar, como escreveu Burnyeat, representa uma possível saída das "perspectivas paroquiais da existência cotidiana”, uma "condução de cá para lá" (pense-se no katoikizein de que se falou no Cap. 8). Um ato persuasivo de imagi- 
nação alternativa, acrescenta Schofield, que vale como "tentativa de verificação de como poderia a estrutura inteira da sociedade [...] ser constituída de maneira diversa e melhor", porque uma esperança sem dimensão utópica é demasiado pouco ambiciosa para construir uma alternativa à realidade presente (pp. 199 seg.). E, como se perguntou recentemente Morrison, a quem pode ser útil esta representação utópica? Certamente, responde ele, para oferecer aos filósofos da cidade histórica "uma razão política para defender a causa da filosofia na sua sociedade, com o fim de aproximar ou tornar mais provável o dia em que os filósofos reinarão nela” (p. 247). Mas, pode-se acrescentar, também para convencer quem não é filósofo a acreditar que numa cidade justa a vida seria mais feliz para todos e, por conseguinte, a aceitar o reino filosófico, ou - como pensam alguns - a ditadura de uma elite racional.

\section{DA UTOPIA PROJETUAL À TEORIA NORMATIVA}

A República é, certamente, uma utopia projetual, não uma utopia de evasão. Mas é provável que seja também algo mais do que isso. Na linguagem da filosofia contemporânea, creio que se possa falar de uma "teoria normativa" acerca da sociedade justa (e não é errado fazer uma referência à posição de John Rawls).

A passagem do mythologein, da imaginação mitopoiética, à teoria normativa - uma passagem que do nosso ponto de vista é muito mais marcada do que do 
ponto de vista de Platão - é assinalada pela introdução de alguns critérios de validação, apropriados à teoria mas certamente supérfluos para a ficção mítica. $\mathrm{O}$ primeiro deles consiste na repetida asserção platônica da "conformidade com a natureza" (katà physin) das suas propostas (veja-se, por exemplo, V 455d). Esta referência que se baseia na "natureza" como elemento fundador apresenta um duplo valor. Por um lado, ela é descritiva e diz respeito à ordem observável da realidade: por exemplo, a paridade de funções entre homens e mulheres é confirmada pelo comportamento efetivo dos cães, os quais, machos e fêmeas, colaboram na realização das mesmas tarefas de caça e de guarda. Por outro lado, a referência à "natureza" é, pelo contrário, normativa, e concerne à melhor ordem possível das coisas, tal como resulta da compreensão da estrutura paradigmática do mundo noético-ideal ( $c f$. , por exemplo, VI 484c-d).

Em ambos os casos, a conformidade à natureza acarreta uma atitude crítica face ao existente ("são as instituições atuais, contrárias àquela que propomos, a parecerem ser constituídas contra natureza”, V 456c), e legitima os pedidos da teoria normativa.

Pelo contrário, onde a conformidade à ordem natural observável não puder desempenhar esta função (como no caso da comunhão de mulheres e filhos), o critério de validação identifica-se na coerência interna da argumentação. Que aquela comunhão seja "consequente [epomene] ao resto da constituição, é preciso confirmá-lo com o logos" (V 461e). Trata-se de provar a consistência dos diversos aspectos da legislação com 
os objetivos do projeto constitucional. Esta consistência toma a forma de uma necessidade condicional: se certos objetivos gerais (tais como a justiça, a felicidade, a unidade da comunidade social) são desejáveis, então é preciso prever as medidas argumentativamente necessárias para os realizar. A coerência intrínseca da argumentação, que conecta os enunciados de modo "espontâneo" ou "automático" (apò tou automatou, VI 498e), une-se assim à referência à natureza como condição de validade da teoria normativa.

Conceber a utopia platônica também como uma teoria normativa contribui para o esclarecimento, de um outro ponto de vista e com outra linguagem, da tanto discutida questão da possibilidade de realização, mesmo que seja imperfeita, do projeto utópico. Como mostrou Federico Zuolo, a utopia de Platão pertence à tipologia das teorias normativas que se dotam, também, de uma teoria da eficácia, que analisa - embora sempre em âmbito infrateórico - as condições necessárias e suficientes para a atuação prático-histórica do modelo de valores proposto.

Para Platão estas condições de possibilidade são fundamentalmente duas: 1. que os "verdadeiros" filósofos assumam o poder nas cidades; ou então, 2. que os dynastai, que já o detêm, comecem a praticar a filosofia (Resp. V 473b-d) (ou, em via subordinada, que aceitem seguir a liderança de um filósofo legislador, Leis IV 709e-710d). Uma "mudança mínima" na estrutura do vértice de governo político, define Platão (V 473b), que, todavia, requer, em ambos os casos, uma série complexa de outras condiçôes preliminares. No primeiro caso, trata-se do seguinte: 
1a. É preciso que, na cidade histórica, se possam encontrar filósofos "verdadeiros" aptos a governar. Isto é difícil, porque a cidade não promove a formação dos filósofos, que devem, pois, "autoformar-se" em condiçôes hostis (VII 520b), e porque ela tende a corromper aqueles existentes, cuja eventual persistência é devida a uma "sorte divina", theia tyche ou theia moira (VI 492a, 493a): é necessário esclarecer desde já que nestas e em outras passagens semelhantes, "divino" equivale a "caso excepcional, extraordinariamente afortunado".

1b. É preciso, também, que estes filósofos se ponham à disposição de um envolvimento político, o que pode depender de uma "fortuita necessidade" (VI 499b, 500d) ou ainda de uma "sorte divina” (IX 592a).

1c. É preciso, por fim, que a multidão de cidadãos se deixe convencer e confie aos filósofos o governo da cidade (VI 501e seg.).

No segundo caso, as condições são as seguintes:

2a. Que existam homens de poder, ou filhos seus, dotados de uma natureza bem disposta à filosofia: isto não é provável, mas não pode ser declarado impossível em toda a duração do tempo (VI 502a).

2b. Que eles se convertam à filosofia, ou aceitem a sua guia, em virtude de uma qualquer "inspiração divina" (VI 499b).

$2 c$. Que eles encontrem filósofos que sobreviveram com base nas condiçóes $1 a$. e $1 b$.

$2 d$. Que a cidade seja "obediente" ao seu governo (VI 502a-b): esta é a condição menos difícil, tratando- 
se de dynastai ou até de tiranos, como se afirma no livro IV das Leis (711b-c).

O conjunto destas condições de eficácia mostra que a realização do quadro normativo, como afirma mais repetidamente Platão, é, decerto, difícil, mas, em linha de máxima, não é impossivel (cf., por exemplo, Resp. VI 499c). A não impossibilidade faz com que, num quadro espaço-temporal indeterminado e grande quanto se queira ("no infinito tempo passado, ou [...] em qualquer região bárbara que ignoramos pela sua distância, ou no futuro", VI 499c-d), o grau de probabilidade daquela realização (entenda-se, imperfeita) deva ser considerado diverso de 0 .

Além deste limiar, teoria normativa e teoria da eficácia não podem ir. Elas não excluem a ação política efetiva, ou melhor, mostram as suas finalidades desejáveis e possíveis; mas não constituem um programa político capaz de indicar modos e tempos de ação. Quando muito, a ação política pessoal pode constituir uma consequência que deriva, por motivos morais e psicológicos, da partilha da teoria e das finalidades que ela indica, como resulta da célebre passagem de IX 592 discutida no capítulo anterior. Este nexo extrateórico está claramente indicado na Carta VII, por exemplo, pela decisão de Platão e dos seus "companheiros" acadêmicos de recusarem o envolvimento político nas vicissitudes atenienses e de se empenharem, pelo contrário, nas vicissitudes siracusanas.

O ponto de vista que se propõe aqui permite compreender melhor a relação entre República, Político e Leis. O segundo diálogo deixa na sombra o aspeto 
normativo da teoria para tentar uma análise radical da questão da eficácia: como é possível governar "cientificamente" a existência histórico-política na sua indeterminada variabilidade? Aqui são postos à prova as potencialidades e os limites do poder absoluto e do governo segundo a lei, numa discussão que pode ser considerada um suplemento de reflexão em torno da configuração de um "reino filosófico" delineada mas não aprofundada na República.

Quanto às Leis e à sua "utopia legislativa", a teoria da eficácia introduz dois novos vínculos: contrariamente à República, a teoria normativa aparece aqui aplicável numa cidade que deve ser construída ex novo, isto é, numa colónia em vias de fundação, e não numa cidade historicamente existente; além disso, ela deve ter em conta, mais do que fazia a República, a resistência oposta pela estrutura antropológica de base às tentativas de transformação social. A questão da eficácia reage, então, nos conteúdos da mesma teoria normativa; se deve mostrar-se realizável, ela deve, então, modificar a configuração das suas finalidades, e diminuir as pretensões de perfectibilidade, recusando, por exemplo, a aboliçãa da propriedade privada e da família (que é substituída por um rígido controlo político-social em ambas).

Esta reformulação torna, talvez, possível uma nova "absolvição" de Platão das acusações de Popper? Certamente que não, porque as finalidades propostas pela teoria normativa devem ser consideradas desejáveis para Platão, e a teoria da eficácia mostra também a sua potencial possibilidade de realização, mesmo que 
seja parcial. Quando muito, a discussão deveria ser finalmente deslocada para outro plano: o confronto teórico entre a teoria normativa de Platão e a teoria proposta por Popper (e pelos seus críticos que, apesar de tudo, também a defendem). Poder-se-iam contrapor as críticas de Popper a Platão às de Platão a Popper, e obter-se-ia, deste modo, um nível de análise decisivamente mais interessante.

Ao mesmo tempo, porém, o nexo aqui proposto impede a não comedida leitura politiquista dos textos platônicos praticada nos anos trinta e quarenta do século XX: ler nos diálogos o imediato reflexo das vicissitudes pessoais de Platão, à maneira de Hildebrandt, é absurdo e enganador, porque se trata de textos teóricos, certamente de pertinência ético-política mas não autobiográfica, propagandista ou agitadora.

\section{NOTA BIBLIOGRÁFICA}

A citação de A. GRAMSCI encontra-se em Quaderni del carcere, vol. II, Torino: Einaudi, 1977 (p. 1131). As obras a que fiz referência são citadas na seguinte ordem: M. I. FINLEY, Utopie antiche e moderne, in Id., Uso e abuso della storia (1975), tradução italiana Torino: Einaudi, 1981 (pp. 267-89); M. BURNYEAT, Utopia and Fantasy. The Practicability of Plato's Ideally Just City, in J. Hopkins, A. Savile (eds.), Psychoanalysis, Mind and Art, Oxford: Oxford University Press, 1992 (pp. 175-87); M. SCHOFIELD, Plato. Political Philosophy, Oxford: Oxford University Press, 
2006; D. R. MORRISON, The Utopian Character of Plato's Ideal City, in The Cambridge Companion to Plato's 'Republic', edited by G. R. F. Ferrari, Cambrigde: Cambridge University Press, 2007 (pp. 232-55); F. ZUOLO, Platone e l'efficacia. Realizzabilità della teoria normativa, Sankt Augustin: Academia, 2009.

Sobre a questão da utopia antiga e platônica, indicações úteis encontram-se em: L. BERTELLI, L'utopia, in G. Cambiano, L. Canfora, D. Lanza (a cura di), Lo spazio letterario della Grécia antica, vol. I, tomo I, Roma: Salerno, 1992 (pp. 493524); D. DAWSON, Cities of the Gods. Communist Utopias in Greek Thought, New York: Oxford University Press, 1992; C. QUARTA, La 'Repubblica' di Platone: utopia o stato ideale?, in "Idee", 8 (1993), pp. 103-14; A. M. JACONO, L'utopia greca, in S. Settis (a cura di), I Greci, vol. I, Torino: Einaudi, 1996 (pp. 883-900); C. ROWE, Myth, History and Dialectic in Plato's 'Republic' and 'Timaeus-Critias', in R. Buxton (ed.), From Myth to Reason?, Oxford: Oxford University Press, 1999 (pp. 263-78).

Sobre a República, $c f$., por último, M. VEGETTI, Beltista eiper dynata. Lo statuto dell'utopia nella 'Repubblica', in CR IV, 2000 (pp. 107-47); sobre o Politico e as Leis, A. LAKS, Médiation et coercition. Pour une lecture des 'Lois' de Platon, Villeneuve-d'Ascq: Septentrion, 2005. 
(Página deixada propositadamente em branco) 
10.

\section{PLATÃO POLÍTICO, HOJE}

\section{A POLISSEMIA PLATÔNICA}

V

inte e quatro séculos de hermenêutica do Platão político podem ensinar-nos certamente alguma coisa, tanto sobre Platão quanto sobre os seus intérpretes. De um certo ponto de vista, a vastidão do espectro exegético não nos surpreende, e não pode considerar-se limitada ao âmbito político do pensamento platônico: já a antiguidade nos ofereceu duas imagens radicalmente separadas do Platão teórico, cético para a Academia antiga, hiperdogmático, ao invés, para o neoplatonismo.

Esta amplitude do arco interpretativo, que é inevitável e irredutível, propóe algumas reflexões úteis acerca da natureza mesma da filosofia platônica. Tratase de um "teatro filosófico", articulado numa pluralidade de textos dialogais, onde o que se põe em cena não é tanto uma filosofia quanto o espaço e as formas constitutivas do pensar filosófico em si. Esta estrutura 
peculiar dos escritos de Platão torna, em linha de princípio, impossível uma unificação sistemática, pelo menos, por duas boas razôes: a polifonia dos interlocutores dialógicos, que argumentam teses contrapostas; a variabilidade das situações dialogais, pelos contextos, problemas, estratégias argumentativas usadas, de onde deriva uma ulterior variabilidade das teses defendidas pelos interlocutores, em primeiro lugar, pela própria personagem Sócrates.

Isto não significa, naturalmente, que não sejam reconhecíveis traços constantes que podem consentir a identificação dos núcleos teóricos relativamente transversais em relação às variações dialógicas, e que sejam atribuíveis à filosofia de Platão. Permanece, porém, o fato de a fluidez das situaçóes discursivas nas quais os traços se acham inseridos autorizar uma pluralidade de interpretações possíveis: por exemplo, quer a leitura cética de Platão, quer a dogmática podem aduzir boas razôes em sua defesa. O intérprete pode formular argumentos razoáveis a favor de uma das opções, seja de ordem historiográfica (a prevalência quantitativa ou qualitativa, a proximidade ou distância cronológica das testemunhas), seja também de ordem teórica (plausibilidade e consistência dos textos usados como prova, ou somente como relevância para nós, das respectivas concepçôes). É certo, todavia, que cada decisão demasiado drástica que reduza a filosofia de Platão ao quadro de uma opção exegética exclusiva corre o risco de ser viciada por um preconceito do intérprete. Esforços hermenêuticos orientados podem, diria, devem ser levados a cabo, porque um excesso de tole- 
rância acarreta um pressuposto de irrelevância teórica da interpretação, mas é igualmente verdade que estes esforços devem, por outro lado, aceitar uma margem irredutível de polissemia do seu objeto: o pensar filosófico de Platão - pela mesma forma textual em que é representado - não pode ser reduzido a um sistema unívoco de significados. Se, de resto, isto é verdade para cada grande filósofo, de Aristóteles a Hegel, é, evidentemente, em medida ainda maior para aquele que, dentre eles, deliberadamente recusou fazer uma exposição sistemática e em forma de tratado do próprio pensamento, como lamentava com certo incômodo o próprio Hegel:

se possuíssemos ainda a obra puramente filosófica (dogmática) de Platão [...] então teríamos perante nós a filosofia de Platão na sua forma mais simples. Pelo contrário, possuímos apenas os seus diálogos, e esta forma dificulta o fazermos uma ideia da sua filosofia e o darmos dela uma exposição precisa. A forma dialogal contém muitos elementos, muitos lados heterogêneos ( $L S F$, p. 179).

Acrescente-se uma segunda consideração, que se aproxima do problema do Platão político. Os diálogos platônicos atravessaram, na tradição exegética, diversos percursos, viveram na posteridade vidas diversas. Assim, houve uma tradição (cosmológica) do Timeu, bem presente, por exemplo, no estoicismo e na Idade Meda; uma tradição (espiritualista) do Fédon, entre neoplatonismo e cristianismo; uma tradição (parado- 
xalmente bastante metafísica) do Parmênides, sobretudo em ambiente neoplatônico; e houve uma tradição separada e autônoma do Platão político, que viveu de maneira relativamente isolada das outras. É também verdade que, aos nossos olhos, a República pode apresentar-se como um cruzamento central de ontologia, epistemologia, psicologia e política. Mas só aos nossos olhos: para o neoplatonismo foi um texto marginal, excluído do cânone principal das leituras da escola, para não falar do Político e das Leis, diálogos sobre os quais pesou um grande esquecimento. A ideia mesma de "platonismo" unificado é um produto hermenêutico tardio da tradição do neoplatonismo, tanto antigo quanto renascentista, um produto, por sua vez, possibilitado pela exclusão, pela marginalização, ou pela interpretação redutiva de muitos conjuntos textuais, entre os quais os aporéticos ou até os políticos.

A polissemia estrutural dos textos platônicos, e a relativa autonomia da tradição dos três diálogos especificamente políticos, ajudam a explicar a amplitude da gama de interpretações legitimamente possíveis, e estas, por sua vez, contribuem para melhor compreender a forma constitutiva irredutível do "fazer filosofia” por parte de Platão.

\section{O EXCESSO HERMENÊUTICO}

No campo dos escritos políticos, todavia, não obstante a possibilidade de elasticidade exegética, o contraste das interpretaçóes atingiu limites que podem ser considerados intoleráveis, com resultados, em certos 
casos, francamente patológicos. À cabeça de uma relativa homogeneidade (quer fosse crítica quer não) das leituras antigas, na modernidade tivemos um Platão teórico do "ideal" com Kant e, ao invés, um teórico da "realidade substancial" com Hegel: um Platão liberal e socialista com Grote, Pölhmann e Natorp, bolchevique com Russell, fascista ou comunista com Crossman, nazi e racista com Hildebrandt e Günther, totalitário com Popper, democrático em certas versões americanas (nada de semelhante, de fato, aconteceu com o pensamento político de Aristóteles).

Tudo isto diz qualquer coisa não tanto sobre Platão, quanto sobre a modernidade que o interpreta. Parecem estar a trabalhar - além das leituras que muitas vezes se mostram penetrantes e, a seu modo, instrutivas - estratégias de assimilação poderosas, que visam fazer do Platão político uma auctoritas a investir na legitimação das diversas opções teóricas e éticas, por vezes, também, a usar diretamente no discurso ideológico e propagandista. Platão - sozinho ou, às vezes, também, forçosamente assimilado ao aristotelismo, sobretudo em ambiente alemão - parece demasiado importante para a autoconsciência da tradição intelectual e política do Ocidente, para poder ser esquecido, ou pior ainda, considerado como um adversário: urge, então, mostrá-lo como um precursor profético, um companheiro de viagem, uma testemunha amiga. Quando tudo isto não parece possível, experimentase, então, uma estratégia de neutralização: para não inserir Platão entre os adversários, considera-se o filósofo estranho à controversa dimensão política e ao 
significado literal dos seus textos. Uma estratégia, esta, amplamente experimentada de Strauss a Gadamer, de Annas a Roochnik, que mata o paciente pretendendo descontaminá-lo das suas toxinas.

São exceções, neste quadro assimilativo, posições menos sensíveis ao prestígio da tradição, como é, em ambiente anglo-saxão, a posição do anti-historicista Popper, ou, nos países socialistas, as posiçóes do marxismo-leninismo: umas e outras não hesitam em desmascarar Platão, acusando-o, por um lado, de ser um inimigo totalitário da democracia, por outro, o ideólogo reacionário. Também aqui, todavia, age, na maioria dos casos, uma espécie de assimilação em negativo: Platão é reconduzido à classe dos mestres medíocres, como Hegel e Marx, de um lado, e à "linha" idealista dos inimigos do socialismo, de outro.

É caso de repetir: em quase todos estes autores há algo que podemos aprender. Mas, no conjunto, as estratégias de assimilação constituem um tela opaca que não permite pensar verdadeiramente o Platão político, na sua eventual relevância, porque o obrigam a ser um precursor cuja verdade se encontra fora dele, isto é, nas posições da modernidade (seja liberal-democrata, socialista ou totalitária), valendo-se delas como de uma fonte de validação e de legitimação.

\section{O QUE SOBRA?}

Sobra, em primeiro lugar, a tarefa inevitável da verificação historiográfica, que deveria proceder, finalmente, livre dos gravosos empenhos de assimilação, 
justificação, neutralização; uma tarefa que hoje pode valer-se de uma nova e mais refinada consciência metódica, capaz de chamar a atenção para os contextos culturais, para a forma dialogal, para o papel das metáforas e da narração mítica, para as dinâmicas argumentativas da escrita filosófica platónica.

Mas precisamente este trabalho, ao devolver o Platão político à sua diferença radical relativamente às posições dominantes do pensamento político, pode torná-lo de novo "bom para pensar" também as questôes do nosso presente - fazendo dele um observatório precioso, em virtude da sua distância. Bastará indicar sumariamente alguns pontos de vista, críticos, por um lado, proposicionais, por outro, que este observatório permite assumir em toda a sua radicalidade.

Há, pois, antes de tudo, uma crítica intransigente à democracia demagógica: o regime onde quem governa, em vez de guiar as massas adula os seus piores instintos, com o objetivo de usar o poder para os próprios interesses; um regime dotado de uma extraordinária potência conformadora e homologatória, que torna difícil propor e praticar alternativas de sistema; um regime, por fim, privado de ordem de valores e abandonado à anarquia dos interesses, dos desejos irracionais, dos impulsos ocasionais. A crítica política à democracia fundase, em Platão, numa ulterior crítica ao seu pressuposto antropológico: a igualdade de dotes entre os homens concebida como dom natural e não como tarefa social a alcançar. Uma sociedade de "irmãos" (Resp. III 415a), de "homens livres e amigos" (VIII 547c), é uma sociedade que, talvez possa ser construída, com grandes difi- 
culdades devidas exatamente à deformidade qualitativa do material humano no qual se trabalha, por obra de um governo inspirado na razão; mas não é, de modo nenhum, o produto espontâneo de uma distribuição igualitária natural de dotação moral e intelectual entre os homens. De maneiras diferentes, Stefanini, Pradeau e Bertelli insistiram sobre os motivos da crítica platônica à democracia, e sobre a sua duradoura capacidade de estimular uma reflexão em torno dos problemas que este regime coloca também na sua forma ocidental contemporânea, desafiando as imposiçóes de "pensamento único" que tendem a considerá-lo como o estado "final" e insuperável da história.

Igualmente drástica é a crítica platônica à oligarquia, desmascarada como poder dos ricos, exercido sem demasiados escrúpulos em vista do incremento dos próprios patrimônios às custas da comunidade. Aqui está em jogo outro pressuposto antropológico, que seria fortemente defendido por Aristóteles: o direito "natural" à propriedade privada e à transmissão familiar do patrimônio. Sem derrubar este pressuposto, segundo Platão, toda a forma de governo exercida por grupos restritos está destinada a transformar-se inevitavelmente em poder de exploração e espoliação do corpo cívico.

A crítica paralela à anarquia democrática, condenada à demagogia e ao domínio oligárquico da riqueza, acarreta necessariamente, em Platão, a perspectiva de um governo exercido por uma elite legitimada pelo saber e pela dedicação moral ao bem comum, garantida pela recusa do caráter privado do patrimônio e da fa- 
mília. Só um grupo dirigente deste tipo pode guiar e harmonizar a sociedade, em vez de corrompê-la demagogicamente e de quebrá-la no conflito entre ricos e pobres. Esta aliança entre saber e política configura, como escreveu Edmond, um programa de orientação "iluminista” e, por outro lado, constitui uma antecipação interessante do debate em torno da teoria das elites, vivo na cultura política europeia dos inícios do século XX, e ainda hoje não privado de uma potencial atualidade, numa época de crise dos dogmas liberais-democratas.

Por outro lado, encontra-se bem presente em Platão o risco que uma elite de poder se transforme numa oligarquia, e que se verifique uma consequente necessidade de severos procedimentos de seleção e de formação: um problema que se tem colocado de forma perspicaz, tanto na reflexão teórica moderna, de Mosca a Michels (bem como em Pareto, já mencionado por Pöhlmann), quanto nas vicissitudes dos grupos dirigentes dos partidos revolucionários do século XX.

$\mathrm{Na}$ margem crítica, unem-se em Platão aspectos proposicionais, que também se mostram ricos de interesse pela radicalidade com a qual propóem temas de reflexão dificilmente evitáveis. Antes de tudo, é relevante a forma com a qual estes aspectos são configurados: trata-se de um pensamento da grande política, na intersecção entre perspectiva utópica e teoria normativa de grande âmbito. Numa situação histórica em que o pensamento da política, após a crise dos historicismos evolucionistas, tende a ser reduzido de modo asfixiante à administração do existente, à gestão dos negócios quotidianos (delegando implicitamente 
a atores extrapolíticos, por um lado, as decisões estratégicas cruciais, por outro, a tarefa das orientaçóes morais da sociedade), o apelo platônico à necessidade de devolver à política - pensada em grande como "saber régio" - uma capacidade de orientação da vida social na sua complexidade econômica, militar, ética, só pode mostrar-se extremamente relevante, embora não seja difícil classificá-lo hoje, como se fizera já no seu tempo, de "utopia" anacrônica.

Dois aspectos estão no centro deste pensamento da grande política, juntamente com o pensamento já mencionado do governo de uma elite do saber. O primeiro consiste no relevo dado à dimensão da comunidade politica, sobre a qual justamente insistiu Schofield. A comunidade deve ser, segundo Platão, o sujeito e o destinatário da política, interpondo-se entre os dois extremos que na modernidade contribuíram para a tornar irrelevante: por um lado, o estado (como conjunto de aparatos de gestão de poder); por outro lado, a característica privada do individualismo ("burguesa" na linguagem de Hegel) da propriedade e da economia. A comunidade política é o lugar de formação do "cidadão", dado que é distinto do "súbdito" do estado e, precisamente, do "burguês" da esfera econômico-familiar. A sociedade da polis, da qual Platão é teórico e crítico, propóe uma terceira via entre estado e privado, ou seja, a via da comunidade: trata-se, também aqui, de uma perspectiva absolutamente não inatual, dada a vivacidade, mesmo com os seus excessos, do pensamento comunitário contemporâneo. Do ponto de vista deste último, a perspectiva do governo das elites aparece, pro- 
vavelmente, em contradição com a comunitária, mas não creio que se possa excluir que os dois termos da contradição possam ser utilmente pensados em conjunto, numa tensão não improfícua.

Por último - mas para muitos se trata, talvez, do aspecto mais importante do legado intelectual do Platão político - deve ser mencionada a infatigável insistência sobre o nexo necessário entre política e ética, poder e virtude: não há felicidade pública sem justiça na conduta social e individual. E, convém acrescentar, não há justiça sem um sistemático empenhamento de educação pública por parte da comunidade política, que constrói a sua unidade num permanente trabalho de autoeducação. O nexo entre política, virtude e educação foi vigorosamente recuperado, na modernidade, pelo pensamento dos jacobinos; mas trata-se de uma exigência que nunca pode ser dada como exigência superada ou irrelevante, e a ela Platão oferece, mais uma vez, uma perspectiva de pensamento radical.

Tudo isto reenvia, por fim, para uma questão teórica que certamente Platão não resolve, mas que contribui para tornar radical. Cada "grande política" tem ambições de transformação demiúrgica do mundo moral e social, e tende a conceber o seu projeto como uma obra de arte de que o filósofo e o político são os artífices. Esta transformação esbarra não só com os seus adversários políticos, mas também contra a resistência antropológica de uma "natureza humana" que resulta da sedimentação, no tempo de formas de vida e de concepções do mundo, e, além dela, resulta das pulsões que caracterizam o ser humano historicamente dado (aquele 
núcleo de ambições e desejos que Platão caracterizava como o estrato do thymoeidés e do epithymetikón). Sobre a tenacidade desta resistência chamaram a atenção eficazmente, depois de Zeller, tanto Pöhlmann quanto Robin e Stefanini. Coloca-se então a questão do encontrar a força (exterior e interior ao indivíduo) necessária a superá-la, uma questão colocada mas, segundo Grote, não resolvida por Platão. Abre-se, por outras palavras, o problema da relação entre persuasão, educação e coerção que, ao que parece, são evidentemente necessárias à "grande política", sendo a última chamada a suprir, pelo menos provisoriamente, os efeitos das primeiras duas que requerem tempos mais longos, ou até longuíssimos, visto as resistências que devem enfrentar: com o risco, bem conhecido pela modernidade da revolução francesa até às experiências trágicas do século XX, que a coerção se torne o único substituto eficaz para as dificuldades da educação social, daquela Sozialpädagogik em que Natorp depunha uma confiança demasiado otimista, talvez.

Não é necessário continuar com este repertório dos pontos de vista que o Platão político é ainda capaz de oferecer à reflexão contemporânea (poder-se-ia acrescentar, por exemplo, a questão da paridade das funçōes entre os sexos a par dos dotes intelectuais e morais). E seria ingênuo, ou, pior ainda, mais uma vez assimilativo, falar de uma sua atualização imediata, de um uso direto no debate contemporâneo. Não se trata de perspectivas que devem ser aceitas ou recusadas enquanto tais, porque pertencem a um horizonte histórico, a uma linguagem filosófica, a uma dimensão 
política irremediavelmente remotos. Em suma, não pode haver hoje, na minha opinião, uma espécie de neoplatonismo político, nem, talvez, deveria haver um neoaristotelismo político (que, ao invés, é largamente difuso, porque parece mais adequado ao pensamento liberal-democrata dominante).

Pretendo dizer outra coisa. Se, realmente, se quer repensar a política de maneira radical, como os tempos parecem requerer, Platão (se for compreendido sem intenções apologéticas, justificativas ou de execração) oferece ainda estímulos críticos e proposicionais que têm interesse para nós. Trata-se, obviamente, de investi-los num quadro de problemas e de interesses que é o nosso, e não podia ser o dele. Distanciar Platão é, talvez, o melhor modo para o tornar mais uma vez interessante.

\section{NOTA BIBLIOGRÁFICA}

As obras às quais se fez referência são as de J.-F. PRADEAU, L. BERTELLI, M. SCHOFIELD já citadas nos CAPS. 7 e 9; também M. P. EDMOND, Le philosophe-roi. Platon et la politique, Paris: Payot 1991. 
(Página deixada propositadamente em branco) 


\section{ÍNDICE DOS NOMES*}

Abbate Michele, 66

Abelardo, 62, 209

Adam Joseph, 242

Agazzi Emilio, 110

Albino, 56

Alcínoo, 235

Alexandre, 133

Annas Julia, 60, 215, 233-6, 238, 248, 253, 276

Antístenes, 178

Apuleio, 248

Arquitas, 31, 161

Aristófanes, 206, 210-2, 216, 258

Aristófanes de Bizâncio, 27

* O índice não inclui os nomes das personagens dos diálogos de Platão e de Cícero. No que diz respeito às notas bibliográficas, são indicados só os nomes dos autores e dos organizadores das obras citadas. 
Aristóteles, 33, 40, 43-55, 57-8, 63, 66, 68, 89-94, 98, 122, 162, 169, 194, 197, 205, 209-0, 218, $227,231,233,273,275,278$

Audano Sérgio, 23

Bambrough Renford, 188-191

Bannes Joachim, 125, 169

Barker Ernest, 160

Bebel August, 97, 103

Bentham Jeremy, 97, 100

Bergson Henri, 207

Berlin Isaiah, 110, 166

Bernardo de Chartres, 62, 209

Bertelli Lucio, 42, 195, 228, 248, 254, 269, 278

Bloom Allan, 216, 229

Blössner Norbert, 60, 236, 237, 253

Bobonich Christopher, 195, 204, 228

Bodin Jean, 65

Brisson Luc, 41, 249, 254

Brucker Jakob, 68-9, 73-4, 108, 206

Brumbaugh Robert, 216, 229

Bruni Leonardo, 63

Brunt Peter A., 234, 248, 254

Burnyeat Myles, 209, 229, 261, 268

Buxton Richard, 269

Calder William M., 110, 140

Cálicles, 34, 130, 131

Calogero Guido, 149-150, 172 
Cambiano Giuseppe, 109, 269

Campanella Tommaso, 258

Canfora Luciano, 139, 269

Cármides, 28, 128, 244

Casertano Gianni, 42, 254

Cavini Walter, 23

Ciani Maria Grazia, 254

Cicero Vincenzo Cícero, 109

Ciro, 164

Cohen Hermann, 105

Comte Auguste, 91, 94, 147

Corisco, 123

Cornford Francis Macdonald, 163-5, 173

Crisolora Manuele, 62

Crítias, 25, 28, 155, 178, 187, 200, 244

Cropsey Joseph, 229

Crossman Richard, 165-9, 173, 176, 182, 195, 275

D’Adio Mario, 108

Dawson David, 34, 42, 269

De Luise Fulvia, 228

Decembrio Pier Candido, 209, 258

Decembrio Uberto, 62

Demócrito, 165

D'Hondt Jacques, 109

Dickinson Lowes, 160

Diès Auguste, 143-4, 156, 172

Diógenes Laércio, 25, 27

Díon, 30-1, 38, 129, 133, 146, 150-1, 153-4, 164, 244, 246-7, 249 
Dionísio I, 29-30, 246

Dionísio II, 30-31, 38, 164, 187, 246

Dixsaut Monique, 191, 228

Dodds Eric, 178, 191

Dostoevskij Fëdor, 165

Duso Giuseppe, 109

Eldestein Ludwig, 254

Edmond Michel-Pierre, 279, 283

Egídio Romano, 62, 209

Empédocles, 132

Epicteto, 54

Erasto Espeusipo, 123

Esposito Roberto, 191

Eurípides, 206

Evola Julius, 149

Farinetti Giuseppe, 109, 228

Farrington Benjamin, 165, 173, 183

Feder Gottfried, 124, 141

Ferrari Franco, 23, 60, 228-230, 254, 269

Ferrari Giovanni, 223-4, 236, 237-8

Ferraris Maurizio, 140

Fezzi Luca, 23

Fichte Johann Gottlieb, 97, 102, 105

Ficino Marsilio, 61, 64-6

Filipe de Macedónia, 164

Filipe de Opunte, 25

Filodemo, 249 
Finley Moses, 41, 206, 229, 248, 254, 259, 268

Fischer Fritz, 140

Forti Simona, 140

Franco Repellini Ferruccio, 139

Frede Dorothea, 191

Frederico II, 75

Fritz Kurt von Funke Hermann, 249, 254, 255

Gabba Emilio, 255

Gadamer Hans Georg, 86, 205-7, 228, 253, 258, 276

Galli Carlo, 191

Galton Francis, 135

Gemisto Pletone, 65

Gentile Marino, 156-9

George Stefan, 125

Gerlach Hans-Martin, 251-2, 255

Giametta Sossio, 140

Giorgini Giovanni, 23, 110

Glucker John, 110, 173

Gobineau Joseph, 135

Goethe Johann Wolfgang, 111, 117

Goldschmidt Victor, 140

Gombrich Ernst, 187

Gomperz Theodor, 82, 86, 90-5, 98, 110, 147, 176, 195

Gramsci Antonio, 257, 268

Griswold Charles, 195-8, 200-3, 227-8

Grote George, 82, 87-92, 95-6, 107, 110, 126, 163, $176,195,221,275,282$

Günther Hans Friederich Karl, 134-6, 141, 149, 183, 275 
Hankins James, 66

Hegel Georg Wilhelm Friederich, 73-5, 77-8, 80-4, $100,104,107,109,114,116,122,127,137,149$, $176,179,181,195,206,208,258,273,275$, 276,280

Heinimann Fritz, 110

Heraclito, 132

Hermia (tirano de Atarneia) Heródoto, 123

Hildebrandt Kurt, 124-130, 132-4, 136, 141, 144, 146, 150-1, 164, 169, 187, 226, 232, 268, 275

Hitler Adolf, 115, 118, 124, 129, 136, 162

Hobbes Thomas, 156, 163, 182, 208, 210, 234

Höffe Otfried, 253

Hyland Drew, 216, 229

Isnardi Parente Margherita, 41, 108-9, 139-140, 249, 254 Isócrates, 164

Jacono Alfonso, 269

Jaeger Werner, 111-112, 115-21, 137, 139, 140, 160, 232 Jâmblico, 56

Jowett Benjamin, 160

Kahn Charles, 140

Kant Immanuel, 67-74, 82, 104-5, 108, 171, 206, 258, 275

Kautski Karl, 97, 170, 252

Kazamanova Ljudmila, 172

Kelsen Hans, 156 
Kircher Athanasius, 94

Kobau Pietro, 140

Kojève Alexandre, 226, 230

Kollontai Alexandra, 161, 170

Korotin Ilse, 140

Kraut Richard, 196, 228

Laks André, 269

Lane Melissa, 21, 173

Lanza Diego, 269

Lassalle Ferdinand, 102

Lembeck Karl-Heinz, 110

Lenine (Vladimir Il'i Ul'janov), 155, 162, 168, 170, 171, 172, 185, 250, 291

Levinson Ronald B. Licurgo, 188-9, 191, 195

Lisi Francesco, 23, 42, 230, 255

Livingstone Richard, 160

Locke John, 156, 234

Longo Mario, 108

Losev Aleksei, 171

Lukács György, 140

Luria Salomon, 171

Machiavel Niccolò, 208, 210

Macróbio, 63

Maddalena Antonio, 249

Maimónides, 208-9

Marco Aurélio, 75

Marx Karl, 80, 85, 96, 109, 171-2, 176, 179, 184, 212,

252, 258 
Maurer Reinhardt, 188, 191

Mazzotti Adele, 173

Mendel Gregor, 135

Michels Roberto, 279

Mill James, 87, 90, 96

Mill John Stuart, 88, 90, 94, 110

Mondolfo Rodolfo, 109

Monoson Sarah, 195, 204, 228

Montinari Mazzino, 140

More Thomas, 106-7, 258

Morrison Donald, 218, 229, 242, 262, 269

Mosca Gaetano, 279

Mosse George L., 140

Movia Giancarlo, 109

Muccioli Federico, 42, 255

Mussolini Benito, 148

Narducci Emanuele, 292

Natorp Paul, 96, 99, 105-7, 110, 170, 253, 261, 275, 282

Neschke-Hentschke, 66

Nethercott Frances, 170, 173

Nietzsche Friedrich Wilhelm, 98, 124-7, 134, 140, 171,224

Novitskii Orest, 170

Oertel Friedrich, 110

Orozco Teresa, 140 
Pareto Vilfredo, 183, 279

Parménides, 274

Patrizi Francesco, 65

Péricles, 34, 94, 196

Pirilampo, 28

Pissavino Paolo, 66

Pitágoras, 132

Plutarco, 28, 246, 249, 255

Pöhlmann Robert von, 92, 96-107, 110, 126, 151, $155,170,261,279,282$

Polo, 34

Popitz Johannes von, 115

Popper Karl, 94, 163, 166, 169, 175-182, 184-191,

193-8, 207, 214, 218, 220, 231, 236, 249, $250,252,267-8,275-6$

Pradeau Jean François, 42, 195, 228, 230, 278, 283

Proclo, 56-62, 64-6, 209, 231

Protágoras, 26-7, 34, 130, 165, 178

Quarta Cosimo, 269

Rawls John, 262

Renaud François, 228

Rickert Heinrich, 121

Robin Léon, 143-7, 172, 282

Romualdi Adriano, 136, 141

Roochnik David, 220, 229, 276

Rosen Stanley, 218, 223-6, 229, 247

Rosenberg Alfred, 128, 134, 169 
Rousseau Jean-Jacques, 102, 135, 156

Rowe Christopher, 202, 218, 228, 269

Rubinstein Matvei, 170

Rudolph Enno, 191

Russell Bertrand, 161-2, 164, 166, 170, 172-3, 187, 195,275

Ryle gilbert, 187, 191

Saint-Simon, Claude-Henri Rouvroy de, 102 Sandkühler Hans Jorg, 110

Santanello Giovanni, 108

Saxonhouse Arlene, 195, 204, 228

Schelling Friedrich, 127

Schenk Günter, 251, 252, 255

Schmitt Carl, 208

Schofield Malcolm, 42

Schopenhauer Arthur, 127

Schottlaender Rudolf, 250-1, 255

Schwarzkopf Ekkehardt, 251, 255

Settis Salvatore, 269

Seung Thomas K., 70, 108

Singer Kurt, 125

Sólon, 172, 199, 227, 244

Sordi Marta, 255

Stallin (Iosif Vissarionovi Džugašvili), 168, 170

Stefanini Luigi, 150-6, 173, 278, 282

Stenzel Julius, 111, 116, 121-3, 137, 139, 249

Strauss Leo, 61, 177, 191, 201, 203, 207-218, 221, 224-6, 229-230 
Temístocles, 34

Timoleonte, 133, 255

Timónides de Leucade, 249

Timpanaro Sebastiano, 110

Tocqueville Alexis de, 94

Toynbee Arnold Joseph, 162-3, 173, 176, 182, 195

Trabattoni Franco, 23

Trampedach Kai Trasilo Trasímaco, 41, 254

Trzaskoma Stephen, 110

Tucídides, 34

Trampedach Kai, 41, 254

Trasilo, 26

Trasímaco, 34, 61, 162

Trzaskoma Stephen, 110

Tucídides, 34

Ugolini Gherardo, 23

Vallet Georg, 255

Vasoli Cesare, 64, 66

Vegetti Mario, 42, 66, 230, 254, 255, 269

Vegetti Matteo, 229

Vieillard-Baron Jean Louis, 108-9

Vitiello Vincenzo, 191

Vlastos Gregory, 196, 228

Vögelin Erich, 159, 232-3, 253 
White Donald, 140

Wilamowitz Ulrich von, 111, 113-116, 119-120, 123, $125,137,139,165,249$

Xenofonte, 89, 164, 200, 210, 226, 230

Zeller Eduard, 82-7, 92, 95, 98, 100, 109, 132, 140, $158,195,282,295$

Zetkin Clara, 170

Zimbrich Ulrike, 141

Zuolo Federi, 23, 264, 269 
(Página deixada propositadamente em branco) 
$\zeta \zeta^{\text {Percebo - ele disse -: queres dizer que a cida- }}$ de cuja fundação estamos discutindo está nos discursos, pois não penso que ela exista em nenhum lugar da terra". "Mas talvez - eu respondi - esteja no céu como um paradigma, à disposição de quem o queira ver, e tenha como objetivo habitá-la" (República 592a-b). 